Andrews University

Digital Commons @ Andrews University

1986

\title{
A Design for Learning and Developing Skills for Handling Interpersonal and Substantive Conflict in the Ardmore, Oklahoma, Seventh-day Adventist Church
}

Jan Gary Johnson

Andrews University

Follow this and additional works at: https://digitalcommons.andrews.edu/dmin

Part of the Practical Theology Commons

\section{Recommended Citation}

Johnson, Jan Gary, "A Design for Learning and Developing Skills for Handling Interpersonal and Substantive Conflict in the Ardmore, Oklahoma, Seventh-day Adventist Church" (1986). Professional Dissertations DMin. 182.

https://dx.doi.org/10.32597/dmin/182

https://digitalcommons.andrews.edu/dmin/182

This Project Report is brought to you for free and open access by the Graduate Research at Digital Commons @ Andrews University. It has been accepted for inclusion in Professional Dissertations DMin by an authorized administrator of Digital Commons @ Andrews University. For more information, please contact repository@andrews.edu. 


\begin{abstract}
A DESIGN FOR LEARNING AND DEVELOPING SKILLS FOR HANDLING INTERPERSONAL AND SUBSTANTIVE CONFLICT IN THE ARDMORE, OKLAHOMA, SEVENTH-DAY ADVENTIST CHURCH
\end{abstract}

by

Jan Gary Johnson

Chairman: Garth D. Thompson 


\title{
ABSTRACT OF GRADUATE STUDENT RESEARCH \\ Project Report
}

\author{
Andrews University \\ Seventh-day Adventist Theological Seminary
}
Title: A DESIGN FOR LEARNING AND DEVELOPING SKILLS FOR HANDLING INTERPERSONAL AND SUBSTANTIVE CONFLICT IN THE ARDMORE, OKLAHOMA, SEVENTH-DAY ADVENTIST CHURCH

Name of researcher: Jan Gary Johnson

Name and degree of faculty adviser: Garth Thompson, Ph.D.

Date completed: July 1986

\section{Problem}

While a great deal of attention has been given in conflict literature to the role of intra-church structures and the political/managerial processes and strategies for conflict intervention and/or management, this project is more concerned with relational matters. That is, the problem addressed in this project is the teaching of certain skills that would help church members preserve their interpersonal relationships even though engaged in conflict. The thesis is that an enlightened 
understanding of conflict and the development of certain communication skills can significantly affect how the parishioner perceives conflict and thus how he/she will behave in conflictive situations thereby reducing the strained interpersonal relationships and alienation that often follows in the wake of conflict.

Method

A conflict skills curriculum was developed for the Ardmore Seventh-day Adventist church. Participants in the project were volunteers from the congregation who met weekly from February 5 to March 27, 1986, for a total of eight sessions. The participants were tested prior to the seminar and again at its conclusion. The same instrument was also administered to a control group for the purpose of comparison (nonequivalent control group design with pretest and posttest). The question addressed by the instrument was, "Will a seminar on conflict change the participants' attitude and feelings about conflict?"

\section{Results}

A comparison of the results of the treatment group and the control group indicate a significant change in the attitude of the treatment group toward conflict. This change indicates a higher level of tolerance for conflict and a feeling on the part of the participants that they can deal more effectively with conflict. It 
can be assumed that this change resulted from exposure to the conflict skills curriculum.

\section{Conclusions}

Indications are that a lay training program in conflict skills development may be effective in raising the level of tolerance for conflict and develop certain interpersonal communication skils that may result in reducing the negative effects of conflict as it relates to interpersonal relationships. 
Andrews University

Seventh-day Adventist Theological Seminary

A DESIGN FOR LEARNING AND DEVELOPING SKILLS FOR

HANDLING INTERPERSONAL AND SUBSTANTIVE

CONFLICT IN THE ARDMORE, OKLAHOMA,

SEVENTH-DAY ADVENTIST CHURCH

\author{
Project Report \\ Presented in Partial Fulfillment \\ of the Requirements for the Degree \\ Doctor of Ministry
}

by

Jan Gary Johnson

July. 1986 
(C) Copyright 1986, Jan Gary Johnson All Rights Reserved 
A DESIGN FOR LEARNING AND DEVELOPING SKILLS FOR HANDIING INTERPERSONAL AND SUBSTANTIVE CONFLICT IN THE ARDMORE, OKLAHOMA, SEVENTH-DAY ADVENTIST CHURCH

A project report

presented in partial fulfillment of the requirements for the degree

Doctor of Ministry

by

Jan Gary Johnson

APP ROVAL BY THE COMMITTEE:

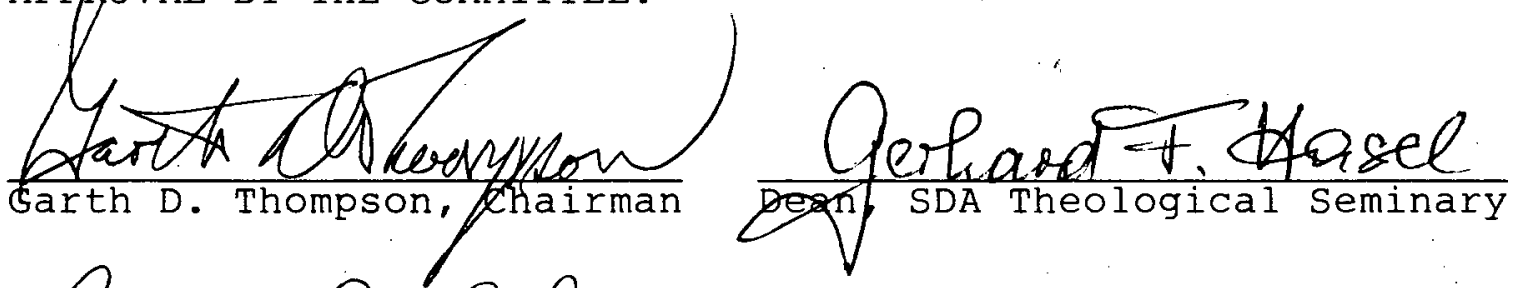
Senganir D. Schocue

Benjantin D. Schoun
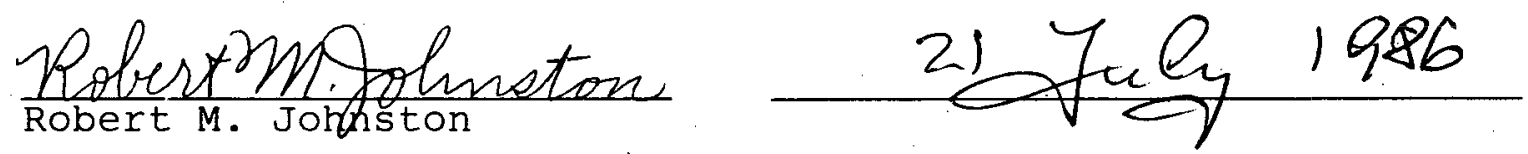
TABLE OF CONTENTS

LIST OF TABLES . . . . . . . . . . . . . vi vi INTRODUCTION . . . . . . . . . . . . . 1

Purpose of the Project ............. 1 Justification of the Project........... 2 Definition of Terms ............ 5 Overview .................. 6 Limitations of the Project... . . . . . . 8

Chapter

I. A THEOLOGY OF CONFLICT . . . . . . . . . 10

Preliminary Considerations . . . . . . 10

Creation--Not Man Apart from God . . . . . 17

Views of the Origin of Conflict . . . . 17

Conflict originated with sin . . . . . 19

Conflict results from human limitations . 21

Conflict results from dualism . . . . . 26

A Godward View of Conflict . . . . . . 29

A Godward approach to theology . . . 30

Potential for conflict resident in

creation !............ . 34

Potential for tension.... . . . 37

Positive results of tensions in

interpersonal relationships . . . . 37

Tension--a potential for confict... 40

Conflict--a conceptual model . . . . 41

Conclusions . . . . . . . . . . . 50

II. THEORETICAL CONSIDERATIONS THAT UNDERLIE A STRATEGY OF CONFLICT TRAINING . . . . . . . 52

Introduction . . . . . . . . . . 52

Conflict Theory in Current Literature... 53

Brief Review of Recent Trends in Conflict
Theory . . . . 53

Assumptions of Conflict That Relate 58

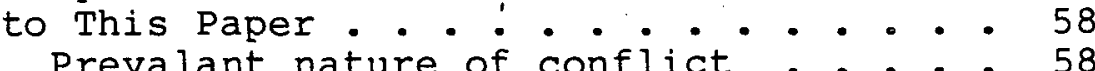

Functional and dysfunctional conflict: 59

Conflict can be managed ....... 61

summary . . . . . . . . . . 62 
Theoretical Base for Learning . . . . . . 64

Analysis of Two Conflict Curricula . . . . 69

"Resolving Our Differences" Curriculum • . 70

Description of the curriculum . . . . 70

The cassette tape--"Resolving Our Differences" ............ 71

The book--Tell It to the Church:

Reconciling out of Court . . . . 72

The manual--Resolving Our

Differences . . . . . . . . 73

Analysis of the curriculum. . . . . . 76

"How to Manage Conflict in the

Church" Curriculum . . . . . . . 78

Description of the curriculum . . . . 79

Analysis of the curriculum . . . . 81

Conclusion Concerning Curricula . . . . 83

Conclusions: An Educational Philosophy . . 83

Education Changes Behavior... . . 83

A Christian Approach to Conflict

values the Person....... . 86

III. DESCRIPTION OF THE PROJECT • . . . . . . . 87

Introduction . - . . . . . . . . . 87

Description of the Church . . . . . . . 88

The Community . . . . . . . . . . . 88

Church Institutions and Services.. . . 90

Ardmore Adventist Hospital . . . . 90

Ardmore Sanatarium and Hospital

Corporation Board . . . . . . 91

Beavers Memorial Junior Academy . . . 93

Kinderland House of Care . . . . . 94

Community Service Center . . . . . 94

The Community Church . . . . . . 95

Analysis of the Ardmore Adventist

Church and the potential for conflict . 95

Description of the Participants . . . . . 98

General statistics... . . . . . . 98

Employment . . . . . . . . . . . 101

Church relationship . . . . . . . 102

Attendance .............. 103

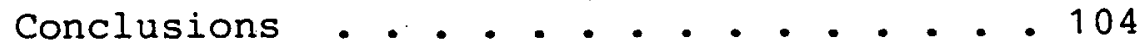

Description of the Conflict Skills
Seminar ........ 105

Seminar objectives . . . . . . . . . 106

Introduction ........... . 106

Statement of the instructional

objectives . . . . . . . . . 106

Objective categories . . . . . . 109

Summary of each session . . . . . . . 111

Session one--"Conflict: Friend

or Foe?" . . . . . . . . . 111 
Session two--"Pricked by Our

Differences" • . • • • • • • • 111

Session three--"You Can Change.

the Course of Conflict". . . . . 112

Session four--"From Win-Lose to

Win-Win" • . • • • • • • • • • 112

Session five--"Dealing with

Emotion in Conflict" . . . . . 113

Session six--"How to Fight Fair" • • • 113

Session seven--"Reconciliation--

the Goal of Christian Confict". • . 114

Session eight--"The Christian

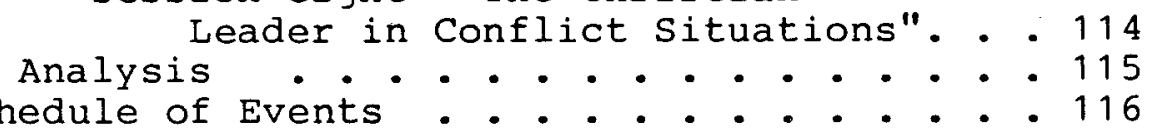

IV. ANALYSIS OF THE PROJECT . . . . . . . . . 120

Testing Results . . . . . . . . . . . 120

Outlook of the Participants... . . . . 125

Handouts . . . . . . . . . . 125

Lectures . . . . . . . . . . . 127

Group activities . . . . . . . . . 128

Homework . . . . . . . . . . . 128

Time allocation . . . . . . . . 129

Personal reflection . . . . . . . 129

Suggestions . . . . . . . . . . . 130

Conclusions of the Pastor . . . . . . . 132

Mechanics and materials of the seminar . . 132

Quality and enthusiam of the group . . . 134

Application made of the material . . . 135

General appraisal . . . . . . . . 135

Recommendations for a Second Implementation . 136

Recommendations based on testing . . . 136

Recommendations based on the

participants' outlook ....... . 138

Recommendations based on the pastor's

conclusions . . . . . . . 139

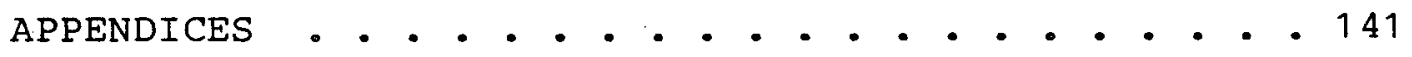

1. Informational Exhibits . . . . . . . 142

2. Conflict Skills Seminar Handouts. . . . 146

3. Evaluative Exhibits . . . . . . . . 323

4. Feedback Exhibits . . . . . . . . 343

BIBLIOGRAPHY . . . . . . . . . . . . 354

VITA .................. 371 


\section{LIST OF TABLES}

1. A Sample of the Heterogeneous Nature of the Creation . . . . . . . . . . . 36

2. The Corruption of Creation . . . . . . . . 42

3. Theological Conceptual Model of Conflict . . 45

4. Analysis of the Seminar Participants . . . . 99

5. Attendance Record . . . . . . . . . 103

6. Categories of the objectives . . . . . . . 110

7. Test Question Analysis . . . . . . . . . 121

8. Estimate of Means . . . . . . . . . . 122

9. Adjusted Group Mean . . . . . . . . . . 122

10. Analysis of Variance . . . . . . . . 124

11. Analysis of the Questions Used in the

Testing Instrument... . . . . . . 328

12. Positive and Negative Alignment of

Questions ............ . . 331 


\section{INTRODUCTION}

\section{Purpose of the Project}

Surprise is perhaps the best word to describe our feelings about conflict in the church. Many mistakenly believe that the love and caring of its members would protect the church from conflictive experiences. When conflict develops, this erroneous opinion leads to feeling that the church has somehow failed. However, the fact that Christians care is a contributive reason why they sometimes engage in conflict; if one does not care about another--about what another is doing or believing-then one will not be motivated to disagree (confront; conflict, fight, argue, etc.) with another. If conflict can be connected with caring, and if the church is the epitome of a caring community, then the presence of conflict in the church should not be surprising and, in fact, should be expected.

The fact that the church is a caring community is instructive in an additional sense. An approach to the management of conflict needs to avoid a mechanistic orientation that seeks to resolve certain issues in conflictive situations but does not bring reconciliation between the antagonists. It seems reasonable to assume 
that the management of conflict in the church should take on an aspect that is uniquely Christian. The theological understanding of the church is that the church hopes for more than other institutions; it not only seeks for a community experience and fellowship that transcends secular organizations, but also it seeks that goal by training and instructing its membership. This training should certainly include methods that are both Christian and effective that would help Christians deal with interpersonal and organizational strife in such a way that interpersonal relationships are ultimately affirmed.

Toward this end, this project reports on the development and implementation of a conflict training curriculum designed to form new attitudes in the minds of the participants toward conflict as well as provide training in certain communication skills that tend to facilitate understanding and promote deepening interpersonal commitment.

\section{Justification of the Project}

My interest in the dynamics of conflict especially as it affects interpersonal relationships developed as I reflected on and evaluated a personal pastoral experience. In the spring of 1980, I was invited to pastor a two-church district in the Mountain View conference. At the time I accepted the position, I was informed that a conflict existed in the district. The 
opinion was conveyed to me that since the conflict was largely theological in nature and seemed to be agitated primarily by the pastor, once he was replaced the controversy would evaporate. As it turned out, however, this underestimated the strength and course of the conflict. A number of distressing factors were immediately evident--communication was emotionally charged, suspicion was rampant, accusations were flying, conspiracies were suspected, conspiracies were present, and "the other side" was seen as the enemy.

The course and impact of conflict in this district exhibited the classic characteristics of conflict's negative results. It resulted in the disintegration of church resources (loss of members, money, and energy); it resulted in dysfunction in the church's program as resources (energy) were spent on nonproductive issues; and it resulted in dissociation as members experienced the agony of interpersonal hostility. 1

As I spoke to my colleagues, I discovered that mine was not an unusual case; most pastors experienced conflict in the pastorate to one degree or another. This casual observation was subsequently verified by several sources. Research carried out by Andrews University Institute of Church Ministry indicates that conflict

${ }^{1}$ speed B. Leas and Paul Kittlaus, Church Fights: Managing Conflict in the Local Church (Philadelphia: Westminster Press, 1973), p. 16-17. 
issues rank high in areas of pastoral frustration and disappointment. 1 For instance, pastors ranked the item, "Poor interrelationships between members," fifth in an overall ranking of ten with twenty items ranked. Perhaps it is just such a reaction to conflict that led Ronnie Littlejohn to assert in his article, "Ministering to Antagonists,"

It occurred to me that the basic obstacle to happiness in church vocations had very little to do with theology or proper biblical interpretation. On the contrary, the nagging exaggeration of what was said (or not said) to this or that person; the opposition over moving a sunday School class; the different impressions over what games to play in the fellowship hall; or how many hymns to have the congregation sing as opposed to the number sung by the choir all seem to be much greater threats to a happy and fruitful ministry. ${ }^{2}$

Another study conducted among Lutheran laymen reported characteristics that they felt pastors should exhibit. The study ranked seventy-seven characteristics of ministry as they perceived their importance. Two characteristics in this study related specifically to conflict: "Creative use of conflict," and "Encouragement of expression of disagreement." Laymen ranked these twenty-fifth and forty-first respectively out of a possible seventy-seven characteristics. ${ }^{3}$ However, in

\footnotetext{
${ }^{1}$ Roger L. Dudley, Des Cummings, Jr. and Greg Clark, "Morale in the Ministry--A Study of the Pastor as a Person," Ministry 54 (December 19.81):7.

${ }^{2}$ Church Administration 23 (December 1980):17.

3 Milo L. Brekke, Merton P. Strommen, and Dorothy
} 
their summary, the authors of this study placed even greater emphasis on these elements of ministry by evaluating them as items that "contribute very much" to an effective ministry. ${ }^{1}$

Finally, two well-known authors in the area of business management, Kenneth W. Thomas and Warren $H$. Schmidt, report that managers spend about 20 percent of their time dealing with conflict. ${ }^{2}$ one may wonder if pastors who are responsible for managing the church would devote any less time to conflict. While our reasoning may tell us that conflict should not exist in the church, the obvious fact is that it does exist. But the recognition or admission of the presence of conflict is not enough. There must be hope and belief that it can be managed constructively. What needs to be understood is that the church can have both harmony and love while at the same time having disagreements. Disagreements do not necessitate disharmony. Division need not spawn hatred. Contention can exist within community.

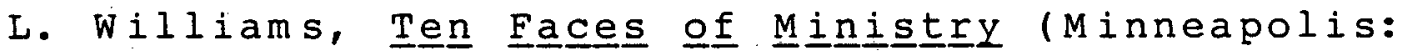
Augsburg, $19791, \mathrm{pp} .13,131$.

'Brekke, et al., p. 195. The items were ranked into eight levels from "absolutely essential for effective ministry" to "absolutely disqualifying." "Contributes very much" to an effective ministry is the second level under "absolutely essential."

2"A Survey of Managerial Interests with Respect to

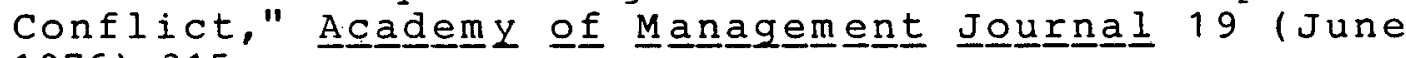
$1976): 315$. 


\section{Definition of Terms}

For the purpose of this project, the word "conflict" is viewed as a neutral term that expresses the presence of perceptual differences between people. These differences may or may not be acted upon or they may or may not be acted upon in a negative or disruptive fashion. According to this definition, conflict is first perceived in the mind before it is exhibited in behavior. This view of conflict allows for two elements that are essential to this project. First, viewing conflict as a neutral element allows for the possibility that either negative and/or positive outcomes can result from conflict. With this understanding of conflict, its presence, course, and management can be understood in the setting of the church.

Second, if conflict is seen as first experienced on the perceptual level, then intervention strategies can be constructed that seek to alter the perceptual functions in such a way that the negative outcomes of conflict are minimized in overt behavior. That is, effective conflict management includes not only procedural or mechanistic strategies but also strategies that will alter the mental processes from which conflictive behavior springs.

\section{Overview}

Formally stated, the task of this project is to 
design and implement a program that will teach human relationship skills that will potentially improve acceptance and affirmation among the members of the Ardmore, Oklahoma, Seventh-day Adventist church as they face interpersonal and/or substantive conflict within the church. The thesis asserts that as members of a congregation are enlightened by a biblical perspective of the nature of the church and by contemporary knowledge of human behavior, they can learn to disagree over perceived facts, methods, goals, or values without experiencing the complication of disintegrating human relationships.

Chapter 1 reviews three theological positions currently espoused in conflict literature comparing the insights they contribute to an understanding of conflict; it analyzes these theological positions as largely a manward perspective of conflict; and it seeks to build a theological model of conflict from a Godward perspective of conflict. Chapter 2 reviews representative conflict literature and explores three widely held assumptions about conflict that have a bearing on the conclusions of this project; it explores educational sources in order to develop a theoretical base for learning; it reviews and analyzes two curricula widely available to church groups that seek to teach conflict management principles; and it develops an educational philosophy based on the foregoing material. Chapter 3 describes the congregation, the participants, the Conflict skills Seminar, and the 
schedule of events. Chapter 4 is an evaluation of the seminar that reviews the results from the conflict Attitude Test; reviews the responses on the participant Feedback sheets; reviews the conclusions of the pastor; and offers recommendations for further research.

\section{Limitations of the Project}

Though it is hoped that there will be certain elements in this project that will meet the needs of Christian bodies generally, the narrow scope of this project must be recognized. First, the theological approach used in this paper to justify the project and the curriculum materials selected for use was developed from a certain theological and doctrinal bias. However, one can hardly approach any issue without attempting to make sense of it by processing it through personal biases. Instead of being a liability, one's personal viewpoint enriched by environmental factors can provide a - researcher with the tools necessary to produce something of significant value for his/her situation that may possibly be of value to others. Therefore, it is hoped that the theology and curriculum developed here will be valuable to other researchers dealing with this subject whatever their biases.

Second, the curriculum materials were selected to meet the needs of the group for which they were used. It remains to be seen if their effectiveness can be 
established in a wider application than indicated by this project.

Third, this project should not be construed as a method of conflict eradication. While it is hoped that those who are exposed to the curriculum developed in this project will be less likely to engage in disruptive behavior in conflictive situations, it may have the effect of actually raising the level of conflict in the church. For instance, instead of withdrawing from conflict or denying the presence of conflict, participants in the seminar may acquire the skills necessary to confront, question, and challenge albeit in a loving and caring manner. 
CHAPTER ONE

\section{A THEOLOGY OF CONFLICT}

\section{Preliminary Considerations}

Conflict is so much a part of social life that it has come to be considered by many theorists as inescapable, inevitable, often legitimate, and perhaps even desirable. ${ }^{1}$ since the church has many characteristics in common with other societal institutions, ${ }^{2}$ it should not be surprising to find conflict in the church as well. 3 Recognition or admission of the presence of conflict in the church, however, is not enough. There need to be some hope and belief that conflict can be managed constructively so that human relationships are

1 see Richard A. Cosier and Thomas L. Ruble, "Research on Conflict-Handling Behavior: An Experimental Approach," Academy of Management Journal 24 (December 1981):816; John L. Hoff, "Conflict Management: An Organizational Principle," The Christian Ministry 4 (January 1973):16; Dennis King, "Three Cheers for Conflict!" Personnel 58 (January-February 1981):13; Eleanor Phillips and Ric Cheston, "Conflict Resolution: What Works?" California Management Review 21 (Summer 1979):76; Ross A. Webber, Management: Basic Elements of Managing Organizations, rev. ed. (Homewood, Ill.: Richard D.-Irwin), p. 446 .

2 James Gustafson, Treasure in Earthen Vessels (New York: Harper and Bros., 1961), p. 99 .

${ }^{3}$ Leslie B. Flynn, Great Church Fights (Wheaton, Il1.: SP Publications, 1976), p. 7 . 
affirmed while the negative effects of conflict are minimized. It is the position of this paper that for such to occur requires not only an intelligent understanding of the processes of conflict but also a commitment by church leaders to the practice of good conflict management techniques.

The bases of a clear understanding of confiict and its management begin with a careful theological study. The doctrines and convictions of the Christian faith, which are seated in such biblical themes as reconciliation, forgiveness, peace, covenants, the Holy spirit, the church as the body of Christ, and members of the body gifted for ministry, seem to indicate that the church is custom-made for conflict ministry and healing. 1

It is as such themes are considered that one discovers that one's approach to conflictual situations will of necessity differ from those who approach conflict with a different set of values and norms. This difference is most clearly seen in the fact that the Christian, especially the Christian pastor and administrator, will approach conflict situations as additional occasions where the ministry of reconciliation can be exercised. It is precisely at this point that the Christian perception differs from other approaches to conflict. On the one hand, most conflict mangement

${ }^{1}$ Lynn R. Buzzard and Laurence Eck, Tell I It toㅡ the Church (Elgin, I11.: David C. Cook, 1982), p. 15 . 
material deals with the satisfactory handling and resolution of the issues that divide, while on the other hand, the Christian approach should tend to be concerned with the persons who experience the division. In other words, the Christian should be person-oriented as well as issueoriented.

There is, then, the potential for a unique approach that the Christian faith can give to the study and handing of conflict. The question is, How will Christians be taught and directed by Christianity in these matters?

The answer to this question comes into focus through the study of the theology of conflict. 1 such a

1 paul Tillich defines theology as".. . the normative and systematic presentation of a concrete realization of the concept of religion" in What Is Religion? (New York: Harper and Row, 1969), p. 33. Norman Shawchuck describes the work of theology as ". . the prayful process of discerning how God may think and act in a given situation, in order that we may know how to think and act in such situations" (How to Manage Conflict in the church: Understanding and Managing Conflict, vol. 1 [ Indianapoìs: Spiritual Growth Press, 1983], p. 8). There may be a question in the mind of some whether theology is necessary or even meaningful in today's world. Richard G. Hutcheson seeks for a balanced understanding. He says that "systematic theology is not the style of the times." He further notes that today is an age of "theological pluralism" instead of the theological normalism that undergirded the work of such men as Aquinas or Calvin. This pluralism, according to Hutcheson's argument, makes a "commonly accepted 'theology of management' . . neither possible nor desirable today." However, even though he suggests that a systematic theology is no longer possible he recommends that church leaders still need to "think theologically" about what they are doing (Wheel within the wheel: Confronting the Management Crisis of the Pluralistic Church [Atlanta: John Knox Press, 1979 ], pp. 11, 24). 
study is necessary in order for the church to understand how to fulfill its task of ministering meaningfully in settings of human fragmentation and alienation. ${ }^{1}$ without this study, the "reality of conflict will remain a mystery" 2 and, therefore, its proper remedy will be lost to the church's view.

An additional reason for undertaking a study of the theology of conflict is based on the fact that the church must first be enlightened by a biblical understanding of the matter before other approaches such as those espoused by the social sciences can be evaluated properly. Those who would undertake such a study must remember that twentieth-century mankind more than ever speaks a secular language. ${ }^{3}$ This situation presents a challenge for the church. That is, the language with which the church feels most comfortable and from which it derives its values, message, and mission is by and large a language foreign to society as a whole. At the same time, the secular humanistic philosophy 4 that now permeates the social sciences and enjoys wide popularity in

${ }^{1}$ Larry L. McSwain and William C. Treadwell, Jr., Conflict Ministry in the Church (Nashville: Broadman Press, 19811, p. 19 .

2 Ibid.

${ }^{3}$ James Hitchcock, What Is Secular Humanism? (Ann Arbor: Servant Books, 1982), pp. 7-17.

${ }^{4} \mathrm{Hitchcock}$ defends the use of the term "secular humanism" (ibid., p. 7 ). 
society is to a great degree a language foreign to the church. The issue facing the church is whether it is possible to reconcile itself to the differences without compromising the purpose for which the church was founded.

Robert $\mathrm{c}$. Worley, who has sought to understand and explain the nature of the church in terms developed by the social sciences, has addressed the problem under discussion by suggesting that the church should "explore the possibility of developing a relation between theology and the social sciences, particularly organizational theory, to see if appropriate terms can be found for reflecting about the church and its ministry."1 He reasons that our "religious language" no longer conveys meaning to society. ${ }^{2}$ In fact, he goes on to say that "The languages of behavioral and social sciences may apply more extensively to our society than do any other languages at this moment." 3

A first reaction to such a suggestion is perhaps resistance. However, one must keep in mind that many of the terms that the church considers religious (e.g., nomos, law; hilaskomai, propitiate; apolutrosis, redemption) are expressions that were first found in the

${ }^{1}$ Change in the Church: A Source of Hope (Philadelphia: westminster Press, 1971), p. 31.

2 Ibid.

3 Ibid. 
pagan worlä but gained acceptance in the New Testament church as the best expression of a spiritual reality. ${ }^{1}$ often the usage of these words was altered significantly as the early Christians filled them with new meaning. ${ }^{2}$ If it is the case that the church from its earliest days borrowed from secular language those terms which suited its purpose, then one should not now expect the situation to have changed. However, it is important to be aware of the dangers inherent in such thinking. For instance, it is possible that with the adoption of a new vocabulary will come new ideas that ultimately can change the complexion of the institution in ways which were not perceived at the outset. 3

Church leaders need to think theologically about what is happening. As leaders search the social sciences for suitable ideas and methods, the question must be asked, Is what we are doing congruent with what we believe? ${ }^{4}$ While it may be a temptation to allow

${ }^{1}$ Alan Richardson, An Introduction to the Theology of the New Testament (New York: Harper and Row, 1958), p. $223 \overline{; F} . \bar{F}$. Bruce, The Books and the Parchments, 3rd ed. (Westwood, N.J.: Fleming H. Revell, 1963), pp. 159-160.

2 Bruce, p. 159 .

${ }^{3}$ Norman C. Kraus, The Authentic Witness (Grand Rapids: Eerdmans, 1979), p. 14. Conversely, Kraus points out that "Even though an orthodox vocabulary is adopted and behavior patterns are codified" there is no guarantee that "social institutions, whether religious, economic, or political, will remain true to the original intention and purposes of their founder."

${ }^{4}$ Hutcheson, p. 24 . 
experience to dictate theology, the reverse must be true. In the words of David Haney, "Our experience needs to be stabilized by sound theology."1

It is possible, then, for a Christian to acquire insights that come from ideas and methods generated within the social sciences, but such insights must always be evaluated in the light provided by revelation. ${ }^{2}$ It is important to remember that while both Christianity and social science are concerned with the nature of mankind and its institutions, they have conflicting presuppositions. That is, while Christianity is seated in the creation-fall-redemption account of mankind's origin, social science holds a humanistic view of mankind that "asserts the dignity and worth of man and his capacity for self-realization through reason and that of ten rejects supernaturalism." 3 This difference between Christian theology and humanistic social science is the subject of the remainder of this chapter.

\footnotetext{
1 The Lord and His La ity (Nashville: Broadman Press, 1978), p. 13 .

2 Lawrence O. Richards and Clyde Hoeldtke, A Theo logy of Church Leadership (Grand Rapids: Zondervan, 1980), p. 9. See also, Eoin Barnard Giller, "Building Up the Body of Christ--A Study in Church Revitalization Leading to Church Growth" (D.Min. project report, Andrews University Theological Seminary, 1977), p. 22; Isaac Rottenburg, "The Christian Versus Christian," Leadership 1 (Spring 1980):60.

${ }^{3}$ Webster's New Collegiate Dictionary, 8 th ed. (1981), s.v. "Humanism." Humanism had its foundation in the work of the 14 th century Italian, Petrarch, "whose scholarship and enthusiasm for classic Latin writings
} 


\section{Creation--Not Mankind Apart from God}

The creation account is a fruitful source of study that enlightens the learner with regard to the meaning of being, the origin and nature of alienation, and the necessity of redemption. It is against this backdrop that the reality and significance of conflict becomes clear.

\section{Views of the Origin of Conflict}

It should be said at the outset that the preponderance of those in the Christian community who have recently reflected on the subject of conflict seem not to have adequately considered either the nature of conflict or its origin. Instead, most authors simply accept the presence of conflict as normal and concern themselves with more pragmatic issues such as the methods of managing conflict. 1

gave great impetus to a movement that eventually spread from Italy to all of western Europe." Originally. humanism "made man the measure of all things" and exalted "man's relationship to God, his free will, and his superiority over nature." of late, the term has come to "refer to value systems that emphasize the personal worth of each individual but that do not include a belief of God." Some Christians have referred to Christianity as humanistic. For instance, Karl Barth said that "there is no humanism without the Gospel." Encycloopaedia Britannica, 15 th ed. s.v. "Humanism." See Hitchcock, What Is Secular Humanism?, for a discussion of the development of humanism from the Renaissance to the twentieth century.

${ }^{1}$ see Lynn R. Buzzard and Juanita Buzzard, Resolving Our Differences (Elgin, Ill.: David C. Cook, 1982); Flynn, Great Church Fights; Arnold Kurtz, "The Pastor As a Manager of Conflict in the Church," Andrews 
While it is true that conflict seems to be a constant part of all human experience, one may ask if it was God's original plan for mankind. By way of example, Christians generally propose that sin was not originally a part of God's creation. However, sin may be considered a "normal" part of human existence now in the sense that it is "common" to all humans; at the same time it must be pointed out that sin is a corruption of the creation. 1 That is, God did not create mankind for sin; further, he does not plan to allow his creation to remain in sin. 2 Therefore, while sin may be considered the normal experience of mankind's current state, in its broader context it has to be seen as a temporary aberration in God's creation. It remains to be seen if the same must be said of conflict. At any rate, it is clear that a.

University seminary studies 20 (Summer 1982): 111-126; idem, "The Pastor and Institutionalization of conflict Management in the Church," Andrews University Seminary Studies 20 (Autumn 1982):217-227; speed Leas, A Lay Person's Guide to Conflict Management (Washington, D.C.: Alban Institute, 1979); idem, Leadership and Conflict, Lyle E. Schaller series in creative leadership (Nashville: Abingdon, 1982); Speed Leas and Paul Kittlaus; Ronnie Littlejohn, pp. 17-20; John M. Miller, The Contentious Community (Philadelphia: The Westminster Press, 1978); Robert T. Newbold, Jr. "Conflict in the Black Church," Leadership 1 (Spring 1980):99-101; Lloyd M. Perry and Gilbert A. Peterson, Churches in Crisis (Chicago: Moody Press, 1981); William C. Rook, "Understanding Conflict in the Church," Church Administration 23 (December 1980): 15-16; John s. Savage, "Getting In and Out of Conflict," Your Church 30 (March/April 1984):42-44, 51.

$$
\begin{aligned}
& { }^{1} \text { Rom } 3: 23 ; 8: 19-23 . \\
& 21 \text { Cor } 15: 52 ; \operatorname{Rev} 21: 4 .
\end{aligned}
$$


consideration of creation and the subsequent fall of mankind not only influences one's understanding of such things as the presence of sin but may also contribute to one's understanding of the nature of conflict. This in turn would essentially affect the development of methods and tools for dealing with interpersonal or intragroup conflict.

Therefore, it is the pursuit of an adequate understanding of the nature of conflict that compels one to look for its possible origins. It can be seen that a definition of conflict is largely affected by one's view of its origin. In search of its origin a brief overview of three views of the origin of conflict is considered. These views are not meant to be exhaustive; they are, rather, instructive synopses in that they offer guidance as the subject in question is pursued.

\section{Conflict originated with sin}

The first view of the origin of conflict to consider is that all conflict and division is the result of the fall. G. C. Berkouwer, for instance, states emphatically that "division of the Church has its origin in human sin."1 He continues by saying, continuing sinfulness, nearly unavoidable
conts personal life always embraces

${ }^{1}$ The Church (Grand Rapids: Eerdmans, 1976), p. 33. Though Berkouwer is primarily concerned here with denominationalism, he reasons that it is human sin that causes conflicts which result in such divisions. 
imperfection, - - . and that his continuing resistance can also be noted in the church.

A similar view is espoused by Ben Patterson in an article published in the conflict and crisis issue of Leadership. There he asks, "Why is there church conflict in the first place?" 2 He answers as follows:

It's because we church people are sinners. . . Church conflict will always find its roots in our passion to make ourselves--our needs, our opinions, our group 3 our goals, our theology--the center of the universe. 3

Further, McSwain and Treadwell, suggest that mankind was meant to lead a conflict-free existence as is witnessed by mankind's condition prior to the fall. They base their view on the argument that prior to the fall the "divine expectation" for mankind was rooted in the fact that both human and divine-human relationships are portrayed in scripture as "communication without distortion and communion without fracture." 4

So it would seem, according to this view, that God created mankind free from the elements that produce interpersonal conflict. Since this view holds that both conflict and sin have a common origin in the fall, it would be natural to see conflict--if not as an extension

${ }^{1}$ Berkouwer, The Church, pp. 33-34.

2"A Small Pump at the Edge of the Swamp?" Leadership 1 (Spring 1980): 42 .

3 Ibid. See also, shawchuck, 브으 toㅡ Maㅡ므믈 Conflict, pp. 8-9.

${ }^{4}$ Conflict Ministry, p. 21. 
of sin, then certainly--as a result of sin. In either case, it would follow that as humans are redeemed from sin they must also be redeemed from conflict. The inescapable conclusion is that conflict is as unwelcome, destructive, and foreign to the church as is sin. Realistically, however, exponents of this view admit and justify the presence of both conflict and $\sin$ in the church by saying that the church is a community of sinners who are being saved by grace. ${ }^{1}$

While it is true that this view answers some of the questions regarding the origin and nature of conflict, its primary weakness is that since conflict is so closely tied to sin it does not easily allow for benefits that obviously can come from some conflict situations. The weakness of this view, however, is the strength of the view to be discussed next.

\section{Conflict results from}

human limitations

A second view of the origin of conflict holds that it is less a result of direct and immediate personal sin and more a result of social or psychosocial factors. Perry and Peterson, for instance, say that conflict develops when there is a failure to use the "tools and skills that God has put at our disposal to allow us to function productively as human beings in organizational

\footnotetext{
${ }^{1}$ MCSwain and Treadwell, p. 24.
} 
relationships."1 They further define these "tools" as "clear communication, design, purpose, goals, organization, and rules or controls for proper behavior." 2 In like manner, Buzzard and Eck suggest that conflict results from genuine and important differences that naturally exist between people. They identify these differences in terms of values, goals, or means to achieve goals and suggest that these differences lead to controversy that "draws out our competitiveness, ego insecurities, and sensitivities." 3

This view traces the origin of conflict to the limitations of being human rather than to human sin. Such factors as differing social histories, values, and Iife-styles all combine to create natural barriers in interpersonal relationships. In this vein, Robert $C$. Richard and Dell olsen hold that

": these differences can hardly be thought of as "sinful" since they are a result of a sociological process which is different for everyone. Conflicts arising out of the differences, therefore, are a result of the limitations of the human situation. 4

This is not seen to suggest, however, that sin does not play a part in conflictive situations. Richard

$$
\begin{aligned}
& { }^{1} \mathrm{P} . \\
& { }^{2} \text { Ibid. } \\
& { }^{3} \mathrm{P} .
\end{aligned}
$$

4 "Go to Your Corners and Come out Fighting! The Psychologist as Conflict Manager," Theolology, Newㅗ aㅡㅁ Notes (October 1976):7. 
and olsen further point out that in their view sin may enter in when "conflict management... [is] met with selfish and egocentric responses." 1 They conclude, however, that "conflict per se does not have to be considered sinful and thus always thought of as a 'bad' experience in the life of the local congregation."2

Along similar lines, Newbold contends that "conflict is not immoral; it is amoral." 3 That is, "It can come out of a sin; but it need not be sinful."4 In fact, for Newbold conflict is "a natural result of human interaction, and is inherent in organization [sic]." 5

As a result of viewing conflict in more positive terms than the previous view, it is not surprising that exponents of this view tend to speak in terms of its management rather than its eradication. The theological justification for this position is based in the proposition that conflict itself existed prior to the fall albeit exacerbated by the fall. Note Richard and Olsen's comment:

We need to recognize that the amount and intensity of conflict and the degree of difficulty in managing

${ }^{1} \mathrm{P} .7$.

2 Ibid.

"Conflict in the Black Church," p. 99.

${ }^{4}$ Ibid.

${ }^{5}$ Ibid. 
it would be considerably lessened had there never been the Fall.

It is significant that Richard and olsen speak in terms of the "amount and intensity" of conflict being affected by the fall rather than conflict itself being introduced by the fall.

It would seem to follow, then, that according to this view, if conflict existed prior to the fall, either God created it or he created the elements that produced it. In either case G. Douglass Lewis seems to suggest that God is responsible for it because of the fact that he created humans as "intentional beings (beings with wills)" with the freedom to decide, take action, and even to separate themselves from God. ${ }^{2}$ That is to say, he is responsible for the positive elements of conflict, but the negative elements must be assigned to the impact that the fall had on the processes that naturally resided in creation. Further, if conflict was a part of human relations prior to the fall, one should expect conflict to be present in human relationships following the fall.

\section{${ }^{1} \mathrm{P} .7$}

$2^{2}$ otice the comments of $G$. Douglass Lewis, "Is it God's fault? Yes, in one sense it is!. God created us as intentional beings (beings with wills) whose natures are social and historical. .. Because we are intentional beings we hope and plan for the future. In pursuit of these hopes we encounter others on their quests.

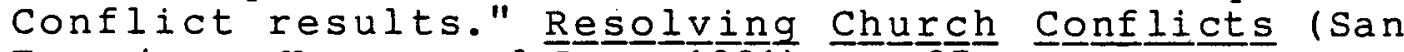
Francisco: Harper and Row, 1981), p. 27. 
That is to say, in society at large and in the church, conflict will be evident and inevitable.

Though Lewis agrees with Richard and Olsen when they say that conflict cannot be equated with sin, he cautions that their view presents a danger. He points out that in an effort to "legitimatize conflict in the church," Richard and olsen. and other exponents of this view rely heavily on behavioral science explanations of the origin and nature of conflict and as a result, this view may not take "conflict or sin seriously enough."1 For instance, referring to the above statement by Richard and Olsen, Lewis says,". . to understand sin as being present only when one is acting selfishly and egocentrically is to misunderstand the nature of sin."2 Lewis takes the position that it is possible to take both conflict and sin seriously and see it as pervasive in the human condition and at the same time affirm that "conflict is manageable and sin is redeemable!"3 To do less, he contends, would result in a laissez-faire posture toward conflict. Lewis comments,

Not to take conflict or sin seriously enough subtly tempts one to deny their reality and not work

${ }^{1} \mathrm{Pp}$. 39-40. Kurtz holds that to think of conflict in such psychological terms as the "interaction of desires" eliminates the connotation of good and bad ("Pastor as a Manager of Conflict," p. 113).

$2 \mathrm{P} .40$.

3 Ibid. 
at management of conflict or a response to God's redemptive activity.

Lewis summarizes his position as follows:

Conflict should not be equated with sin, but inevitably under the conditions of finite existence, our sinful nature makes conflict potentially destructive and debilitating. As willful beings who are invariably sinful, we can be counted on to see things from our perspective and to pursue our fulfillment through the achievement of our goals. At the same time, however, we also have the capacity to be open to, affirm, and care about the concerns of others.

In summary, it seems that what is seen as the weakness of the first view (i.e., that it was unable to account adequately for the benefits of conflict) is the strength of this second view. Conversely, what is seen as the strength of the first view (i.e., the identification of conflict with human $\sin$ ) is the weakness of this second view. Additionally, these two views differ as to when conflict originated. While the first view holds that conflict originated with the fall, this second view sees conflict knitted into the fabric of the creation event itself, albeit exacerbated by the fall.

Conflict results from dualism

Ronald C. Arnett suggests another view of the origin of conflict which reflects some of the discussion among representatives of the "peace churches." 3 Though

1P. 40.

2 Pp. $40-41$.

${ }^{3}$ Dwe 11 in eㅡ Peace (Elgin, Ill.: The Brethren Press, 1980), p. 11 . 
this view does not seem to be widely held, it is, nevertheless, an important one to consider in that it represents an attempt to synthesize the preceding two views.

Foundational to Arnett's argument is his discus sion concerning the complexity of human nature which, he says, defies description by any one particular theory. 1 As a result, Arnett sees justification not only in examining various views of the nature of mankind (i.e., theological, psychological, and sociological) but also in synthesizing these, not for the purpose of "correctness or validity," but for the "ability to structure an individual's view of the human." 2

Basically, he examines two views of human nature. The first says that mankind is essentially evil and has a "natural tendency for evil or choosing alternatives that produce destructive results."3 The second claims that mankind is "primarily good" seeking to "achieve more meaning and satisfaction from life." 4 Analyzing what on the surface appears to be conflicting philosophies of human nature, Arnett deduces that these views demonstrate that mankind "has almost infinite capacities for both

$$
\begin{aligned}
& { }^{1} \mathrm{Pp}, \quad 57-58 \\
& { }^{2} \mathrm{P}, 57 \\
& { }^{3} \mathrm{P} . \\
& { }^{4} \mathrm{P}, \quad 62,
\end{aligned}
$$


good and bad."1 In other words, both destructive and constructive impulses are resident in human nature revealing what he calls the "dual nature of the human predicament." 2

It appears as though Arnett attempts to maintain a tension between what he considers to be two diverse elements in human nature. For him, this dualism explains the presence of pervasive conflict while at the same time giving hope for resolution. Those involved in "peacemaking"--Arnett's term for conflict managers--are to invite the goodness of others to come forward by caring for them. However, Arnett admits that while inviting the goodness to emerge in the face of conflict and confrontation, the peacemaker should not be surprised when, because of mankind's evil impulse, the "antithetical response is the answer." 3

It seems that there are several weaknesses in Arnett's argument that are relevant to this discussion. First, Arnett fails to trace the evil impulse in human nature to its origin and, thereby, he fails to draw adequate implications as to the meaning of wholeness as may have been intended by God for his creatures.

second, there is not adequate consideration as to

1 P. 65.

2 Ibid.

${ }^{3} \mathrm{Pp} .65-66$. 
the possible implications of the nature of conflict. If conflict springs from the evil impulses of mankind, then one would have to assume that conflict itself is evil. If such is the case, then one would be led to question the appropriateness of conflict in the church community. However, Arnett is silent on these matters.

Third, Arnett believes that his dualistic view of human nature allows for the incorporation of the learning from "Freud, Lorenz, and Ardrey as well as Rogers, Maslow, and the humanistic movement." 1 However, his theory fails to give the direction necessary to explain how such widely divergent views as those expressed by these persons can be reconciled with each other, much less incorporated into a Christian context. It would appear, then, that there is wide and divergent opinion among those who have sought to understand the origin of conflict. The question to be addressed now is, Is there a view that is compatible with Seventh-day Adventist theology and if so, what is it? ${ }^{2}$

\section{A Godward View of Conflict}

Foundational to Adventist theology is its emphasis on the cosmological nature of the battle between the forces of good and the forces of evil. Since an

${ }^{1}$ P. 65.

${ }^{2}$ Seventh-day Adventist is referred to as Adventist through the remainder of this paper. 
Adventist view of conflict is flavored by this foundational theology, it seems necessary to discuss first the nature of what is called in this paper the "Adventist Godward" approach to theology. For the purpose of this study, a Godward approach to theology holds that an ontological understanding of the creature is best delineated in the context of the being and activity of the creator.

\section{A Godward approach to theology}

A single underlying factor that seems to appear in the foregoing views is that the theology of conflict is referenced primarily from what is referred to here as a "manward" approach to theology. That is to say, in those views it is the study of mankind with consideration as to its origin and/or nature that enlightens the understanding of conflict. For instance, in all three views it seems that when creation is considered, it is primarily mankind in creation that is considered with respect to communication, communion, intentionality, finiteness, and Iimitations.

Admittedly, one does well to study mankind as one seeks to understand conflict, for it is mankind in its social interactions that is beset with conflict. However, using a manward approach to theology in the study of conflict is to examine only half the evidence, because in the biblical view mankind is not truly mankind 
apart from God. This means that humans cannot be fully understood if they are not considered in the context of their creation, fall, and redemption. To look at these elements of mankind's experience is to discover the true nature of mankind's creatureliness; what mankind is in the context of God's action.' It is only then that one can begin to discover what mankind was to be, is now, and can become all in the context of the action of God. In effect, a Godward approach to theology enables one to better understand mankind and to account for those elements (such as, conflict) that color mankind's. existence.

There is ample evidence for a Godward theology in scripture. Take, for example, the Genesis account of creation. This is not a narrative primarily about mankind, but rather, it is a narrative about God. It is God who moves, acts, speaks, blesses, commands, and redeems in the first three chapters of Genesis. ${ }^{2}$ It is God who calls a world into existence, dresses it with a living mantle, and populates it with multiple living creatures. Finally, it is God who creates as a capstone of his creation an image of himself; that is, man and

${ }^{1}$ Dietrich Bonhoeffer, Creation and Fall, trans. John C. Fletcher (n.p.: SCM Press, 1959; reprint ed., New York: Macmillan, n.d.), pp. 52-53.

$$
{ }^{2} \text { Gen } 1: 2-3,28 \text {. }
$$


woman. ${ }^{1}$ Mankind proceeds from God and represents God's ultimate work in the new creation. 2 Mankind derives its status, employment, authority, and limitations from God. ${ }^{3}$ Ultimately, mankind enjoys its fullest identity and meaning in its relationship with God as is witnessed by the institution of the sabbath rest. 4 In fact, mankind is on ly mankind as it is in God, living as it was created to live. Conversely, apart from God, mankind would lose its true identity. Therefore, the fall succeeded in dehumanizing mankind. It dehumanized mankind by marring the image of God in mankind and by causing a rift in human relationships with God. 5 However, what $\mathrm{sin}$ has corrupted, God seeks to correct through reconciliation that is accomplished through God's activity in Jesus. That is, Jesus is the atonement that reunites fallen humans under the banner of redemption with God. Reconciliation, then, is God's recreative act that seeks to restore mankind to the original intent of creation.

This Godward approach to theology is foundational to Adventist theology. For instance, the visions claimed

${ }^{1}$ Gen $1: 26-27$.

2 Bonhoeffer, Creation and Fall, p. 36 .

${ }^{3}$ Gen $1: 27 ; 2: 15 ; 1: 28$, respectively.

${ }^{4}$ Gen $2: 1-3$.

${ }^{5}$ Bonhoeffer says that man lost his "creatureliness" as the result of the fall (Creation and Fall, p. 72 ). 
by Ellen $G$. White helped preserve the church from a restrictive Millerite concept of earth cleansing and personal preparation to a cosmological view involving a heavenly sanctuary, God sitting in judgment, and a world preparation. ${ }^{1}$ Also, The Great Controversy Between Christ and Satan is not merely the title of the fifth volume of a narrative written by white that covers the history of sin from its inception to its conclusion. The phrase for its shortened form, "the great controversy," or simply, "the controversy") has also come to be frequently used by Adventists to describe the struggle between the forces of good and the forces of evil in the universe. ${ }^{2}$ The history of rebellion that forms the bases of this controversy did not begin, in the Adventist view, with the fall of mankind but with the germination of the seeds of rebellion in Lucifer's mind in heaven. ${ }^{3} \mathrm{sin}$ on earth results from and is an extension of the rebelion that rages on a cosmological scale.

It is clear, therefore, that the Adventist view of being and environment is influenced by Godward theology.

1 Ellen G. White, one of the founders of the Adventist Church, is considered by the church to be an authority on matters of faith.

2 The Great Controversy Between Christ and Satan (Mountain View: Pacific Press, 1911). As an example of the use of the phrase "great controversy" see the publisher's comments in idem, The Patriarchs and Prophets. (Mountain View: Pacific Press, 1958), p. 17.

3Idem., Patriarchs and Prophets, p. 35. 
Human creation, sin, and redemption tend to be viewed in the context of the great controversy between christ and Satan and, thus, human experience is seen against the backdrop of cosmological themes and events.

To summarize, then, a Godward approach to theology accomplishes several things. First, it helps to avoid the humanistic trap of attempting to understand mankind by simply observing its current behavior and ignoring or denying the role and influence of the divine element upon mankind. Second, it allows for the possibility of seeing mankind in the context of a grander (and what Adventist's hold to be a more accurate) scheme that takes on universal proportions. And third, it leads to the conclusion that since mankind proceeds from God a factual understanding of mankind's nature and being must be built on information that is embodied within creation itself.

Potential for conflict resident in creation

It has been noted already that rebellion is not an experience restricted just to mankind. In fact, according to the Adventist view there seems to be no created being throughout the universe that is exempt from the possibility of rebellion. ${ }^{1}$ If this is the case, the

${ }^{1}$ See White, Desire of Ages (Mountain View: Pacific Press, 1898), p. 37 ; idem, The Great Controversy, p. 497 ;

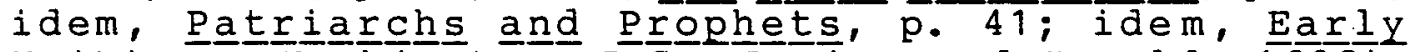
Writings, Washington, D.C.: Review and Herald, 1882), p. 290 . 
fact that the potential for rebellion is so universally dispersed leads one to the assumption that the factors that make rebelion possible are resident in creation itself.

One would expect that all creation has certain elements in common (including the potential for rebellion) in that the universe has a common designer. However, recognizing that the universe has a common origin in one designer is not to say that the universe is entirely homogeneous. Even a casual look at creation either on a terrestrial or cosmic scale instructs with regard to elements of diversity within creation. (see table 1).1 In fact, it can be argued that the presence of diversity is as much a result of a common creator as is homogeneity. That is to say, diversity itself is so common and so uniformly dispersed throughout the creation that it can only be attributed to a single creator.

However, diversity within the creation does not necessarily lead to confusion or conflict. It would appear God's design provided a diversity within creation that would be balanced with order and harmony. Even

${ }^{1}$ Robert $P$. Kishner says that the universe is "richly populated with delightful inhomogeneities" ("Giant Voids in the Universe," 1985 Yearbook of Science and the Future [Chicago: Encyclopaedia Britannica, 1984], p. 48). He holds that this results from differing elements that make up the universe. However, he points out that though its parts are inhomogenious when taken on the whole, the "universe is homogeneous"; a principle called the "Cosmological Principle." 
this--that is, order and harmony--may be seen as a result of God's creative act.

An example of this diversity in creation is witnessed in the human body. Note, for example, the

\section{TABLE 1}

A SAMPLE OF THE HETEROGENEOUS NATURE OF THE CREATION

\begin{tabular}{|c|c|}
\hline Catagory 1 & Catagory 2 \\
\hline $\begin{array}{l}\text { Light } \\
\text { Heat } \\
\text { Wet } \\
\text { Matter } \\
\text { Micro } \\
\text { Male } \\
\text { Right Hemisphere } \\
\quad \text {,(Brain) }\end{array}$ & $\begin{array}{l}\text { Dark } \\
\text { Cold } \\
\text { Dry } \\
\text { Emptiness (Void) } \\
\text { Macro } \\
\text { Female } \\
\text { Left Hemisphere } \\
\quad \text { (Brain) }\end{array}$ \\
\hline
\end{tabular}

variety of cells that comprise the human organism: red blood cells, white blood cells, muscle cells, cartilage cells, fat cells, bone cells, skin cells, reproductive cells, and nerve cells. 1 These cells not only differ in appearance but also differ in function. ${ }^{2}$ It is because of the diversity of these cells--the differing functions carried on in the body--that makes it possible for the body to live, move, and have being.

Nevertheless, there are certain consequences that

${ }^{1}$ Paul Brand and Philip Yancey, Fearfully and Wonderfully Made (Grand Rapids: Zondervan, 1980), pp. 27-28.

2 Ibid., p. 27 . 
naturally emerge from this diversity:

Potential for tension. Diversity even within an ordered and harmonious creation would have the potential of producing certain tension. One must assume, however, that the presence of tension in creation does not represent a destructive element that denies or diminishes the balance of order and harmony. In fact, since tension is God-ordered, it might be assumed that its presence is at least not opposed to order and harmony and may, in fact, be a function of it. At any rate, the presence of tension in creation is well supported by laws of the physical sciences that regulate such things as gravity, magnetism, the molecular structure, and the atomic structure. Interestingly, in each of these tension is a positive and constructive force that contributes to the order of the system.

Positive results of tensions in interpersonal relationships. What has been said thus far about creation generally can be assumed about humans and human relationships specifically. That God intended diversity within the human family is witnessed by the fact that he not only created a male and female but that he created in both a reproductive system that allows for near infinite variety. In addition, as one considers that God intended for mankind to be individual thinkers and individually accountable to himself, one begins to understand 
that the presence of diversity could result in tension. The orderliness of God would instruct us that this tension was not to lead to disharmony--rebellion--between humans or between humans and God. Instead, it seems logical to assume that the tension that God designed in his creation would effectively result in yet richer human relationships through deeper and more meaningful interpersonal contacts. While strict uniformity of human personality would suggest that a person has no original choice to express affection, the individuality allowed by diversity paves the way for varied ways in which affection could be expressed. Certainly, God did not intend for humans to be exact copies of one another. As diverse creatures, mankind would continually be faced with new facets of interpersonal experience marked by spontaneity and variety. The differences between humans would serve to stimulate a genuine interest between creatures and would form the basis upon which commitment would be built. ${ }^{1}$ Any tension that would result from the presence of diversity would be resolved as in all other parts of creation--with balance and order. Instead of

${ }^{1} \mathrm{~A}$ kind of commitment is evident in Adam's choice to enter into Eve's sin rather than be separated from her. See Gen 3:6. White says that Adam understood the nature of Eve's sin and realized that he was faced with a decision of either being separated from God or from her. "Love, gratitude, loyalty to the creator--all were overborne by love to Eve. - He resolved to share her fate; if she must die; he would die with her" (Patriarchs and Prophets, p. 56). 
tension giving way to separation and estrangement, it would actually serve to deepen interpersonal relationships.

A glimpse as to how this might work is found in White's description of the so called "counsel of peace." 1 Here she describes a meeting between God the Father and God the Son in which they discuss the plan of redemption. Though both seem agreed as to the goal (i.e., that mankind must be saved), there is "tension" over plans (i.e., how mankind is to be saved). White alludes to this tension when she describes the son "pleading with His Father" and the Father in a "struggle,.. . to yield up His son to die for the guilty race."2 This tension, however, did not result in a breakdown of communication. Instead, there is evidence that this tension contributed not only to a resolution that provided for mankind's salvation but also resulted in the defining of roles that the members of the Godhead would take in the plan of salvation.

\section{${ }^{1}$ White, Patriarchs and Prophets, p. 63.}

${ }^{2}$ Ibid. See also idem, Early writings, p. 149 . It can be argued that even this tension would not have occurred if it had not been for the fall. Admittedly, all creation has been affected in some way by the fall as has the Creator. However, it seems reasonable to assume that the tension evident in this interchange is not a corruption of the perfect harmony that exists in the universe but rather an underlying factor that helps preserve it. For instance, the result of this tensioninterchange was the launching of a plan that sought to preserve harmony. 
Tension- - a potential f for conflict. Even though tension may have contributed to the order and harmony of creation prior to the fall, it seems to have been through the avenue of tension that satan broke the order and balance of creation which resulted in estrangement, separation, and alienation of interpersonal relationships. It must be said here that one cannot attribute to Satan creative acts. There is only one creator and that is God. Satan is a creature and as a created being he has his limitations. 1 It can be said, then, that satan did not originate conflict in the sense of creating it. Rather, it seems reasonable to assume that he used the elements already present within creation to form his society in rebelition. In effect, the destruction of order and the introduction of conflict seemingly produced by Satan resulted from his ability to alter what God had ordered.

It can be argued, then, that God implanted in his creation the possibility of disorder and conflict by creating the diversity that produced the tension described earlier. Such would be in keeping with similar acts of God such as the creation of mankind as

${ }^{1}$ Berkouwer has noted that the Christian church has largely rejected two errors concerning the origin of sin (S $i n$ [Grand Rapids: Eerdmans, 1971], pp. 68-69). The first is that God is the origin of sin and the second is that of dualism. Concerning dualism, Berkouwer states, ". . she [the church] has denied any notion of a completely autonomous 'counterforce' which has nothing to do with God's originally good creation." 
intentional beings with a free will and the creation of the tree of knowledge of good and evil planted in the garden of Eden to test that will.1

Having said this, however, it cannot also be said that God is responsible for conflict by creating tension in his creation anymore than it can be said that God created licentiousness when he created human sexuality. Satan will have to assume the responsibility of degrading creation because he altered creation. 2

This corruption of creation seems to be the pattern of all sin and sinning. In a sense, sin is not a creation but a corruption of those things in creation that God had placed in perfect balance and order (see table 2 ).

It seems, then, that the doorway to conflict was tensions that God placed in his creation. Though tension was designed for the benefit of the creation, it acted as a doorway through which satan succeeded in introducing conflict and discord.

Conflict--a conceptual model

Generally, theorists define conflict. stressing

${ }^{1}$ Gen $2: 8-9,15-17 ; 3: 17$.

${ }^{2}$ According to Adventist theology, the azazel of Lev 16 represents Satan who must take the blame and punishment for sin, not as a savior/substitute, but as the cause of sin. Questions on Doctrine (Washington, D.C.: Review and Herald, 1957), p. 397. Berkouwer states clearly,".. - God is not the source, or the Cause, or the Author of man's sin" (ㅌin, p. 27). 
either behavior or perception (see Appendix 1, exhibit 1). Kenneth $\mathbf{W}$. Thomas points out that conflict is often defined as a "form of behavior," while noting that his preference is to think of conflict as "the condition in

TABLE 2

THE CORRUPTION OF CREATION

\begin{tabular}{|c|c|}
\hline As Created' & As Corrupted \\
\hline $\begin{array}{l}\text { Sexuality } \\
\text { An expression of love }\end{array}$ & $\begin{array}{l}\text { Licentiousness } \\
\text { A expression of lust }\end{array}$ \\
\hline $\begin{array}{l}\text { Diet } \\
\text { Eat to live }\end{array}$ & $\begin{array}{l}\text { Gluttony } \\
\text { Live to eat }\end{array}$ \\
\hline $\begin{array}{l}\text { Worship } \\
\text { An expression of } \\
\text { gratitude }\end{array}$ & $\begin{array}{l}\text { Idolatry } \\
\text { An expression of } \\
\text { manipulation }\end{array}$ \\
\hline $\begin{array}{l}\text { Happiness } \\
\text { Serving mankind and God }\end{array}$ & $\begin{array}{l}\text { Self-gratification } \\
\text { Serving self }\end{array}$ \\
\hline $\begin{array}{l}\text { Individuality } \\
\text { Accountable to God }\end{array}$ & $\begin{array}{l}\text { Individualism } \\
\text { Accountable to self }\end{array}$ \\
\hline
\end{tabular}

which the concerns of two or more parties appear to be incompatible."1 Though he does not state it specifically, it seems justifiable to understand "concerns" as the result of how one perceives situations. Thomas further notes that it is useful to think of conflict in such terms because

This definition has the advantage of separating conflict from the behaviors that people use to deal

1 "Introduction," Ca liffornia Management Review 21 (Winter 1978):56. 
with it, so that one can talk about the effectiveness of different "conflict-handling behaviors". . . .

It is apparent that Thomas chooses to view conflict in terms of one's perception of a situation rather than one's behavior in a situation for utilitarian reasons. One may wonder if a Christian interpretation of conflict might benefit as well by adopting the same distinction as Thomas between behavior and perception. For example, those in the Christian community who define conflict in terms of behavior generally support the first view of the origin of conflict above--conflict originated with human sin--and also, they tend to view conflict as destructive with little positive resulting from it. 2

On the other hand, those who define conflict in terms of how one perceives a situation tend to hold to

$$
{ }^{1} \text { P. } 56 .
$$

${ }^{2}$ MCSwain and Treadwell, who support this position, seem on the surface to hold both views; conflict is conflictive behavior as well as perceptually based. They first define conflict as ". . . those experiences of individuals and groups trying to achieve goals which are incompatible" which stresses conflict as behavior. Then they quote Ross stagner (Conflict is "a situation in which two or more human beings desire goals which they perceive as being attainable by one or the other but not by both") which is a definition of conflict in terms of preception. They resolve this tension between behavior and perception by including "attitudes" among what they see as one of the four sources of conflict. Therefore, in effect, their primary definition of conflict stresses behavior while admitting that attitudes are a contributing cause of conflict (Conflict Ministry, p. 25); Ross Stagner, ed., The Dimensions of Human Conflict (Detroit: Wayne state university Press, 1967), p. 136, quoted by McSwain and Treadwell, Conflict Ministry, p. 25. 
the second view of the origin of conflict--conflict results from human Iimitations. These theorists also tend to view conflict as neither good nor bad but simply as existing in all human relationships. For this group, the outcome of conflict whether positive or negative depends to a great extent on how it is handled.'

If conflict is to be defined, it must be defined in relationship to a theological framework. Whether it can be adequately accounted for in the framework of the above theology is the question now addressed.

Table 3 sets forth a conceptual model that not only clarifies the nature of conflict by drawing a distinction between the cognitive processes and overt behavior but also seeks to distinguish between the perceptual and the thinking/reasoning (cogitative) functions within the cognitive processes. The distinction here is between how reality is understood and the rational powers that process understanding into action.

Reality is understood through the process of perception. J. W. Kalat defines "perception" as referring both to the "experience of gaining sensory information about the world of people, things, and

${ }^{1}$ For example, Richard and olsen state, "We wish to emphasize that.. . conflict properly managed can become the key to new growth and at the cutting edge of positive human development" ("Go to Your Corners," p. 7). 
events, and to the psychological processes by which this is accomplished."1

Unfortunately, the world is not perceived the same by all who view it. It seems logical to assume that differences in human perception were magnified as the

TÁ்LE 3

THEOLOGICAL CONCEPTUAL MODEL OF CONFLICT

\begin{tabular}{|c|c|c|c|}
\hline $\begin{array}{c}\text { God's Kingdom } \\
\text { of Harmony }\end{array}$ & & $\begin{array}{l}\text { tan's Kingd } \\
\text { f Rebellion }\end{array}$ & \\
\hline \multirow[t]{2}{*}{ Created } & \multicolumn{2}{|c|}{ Cognitive processes } & \multirow{2}{*}{$\begin{array}{l}\text { Overt behavior } \\
\text { (corrupted) }\end{array}$} \\
\hline & $\begin{array}{l}\text { Perceptual } \\
\text { Processes } \\
\text { (altered) }\end{array}$ & $\begin{array}{l}\text { Cogitative } \\
\text { Processes } \\
\text { (corrupted) }\end{array}$ & \\
\hline Tension & \multirow{2}{*}{ Distortion } & $\begin{array}{l}\text { Discordant } \\
\text { Thoughts }\end{array}$ & $\begin{array}{l}\text { Discordant } \\
\text { Behavior }\end{array}$ \\
\hline Sexuality & & $\begin{array}{l}\text { Prurient } \\
\text { Thoughts }\end{array}$ & $\begin{array}{l}\text { Licentious } \\
\text { Behavior }\end{array}$ \\
\hline
\end{tabular}

result of alterations that took place in the physical, emotional, and intellectual makeup of mankind as a consequence of the fall. Some authors, as noted earlier, attribute perceptual differances to the limitations of being human. It seems, however, that human differences at this level is best accounted for by admitting the role of sin in reducing the ability of the human organism to ception.

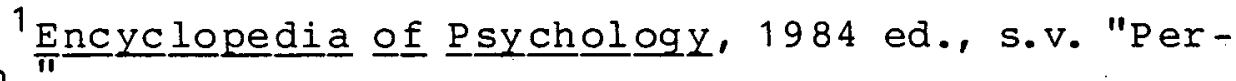


collect and interpret data about its world.

stating that the diminished capacity of the organism is a consequence of the fall is not also saying that perceptual deterioration is sin. Rather, it is simply a recognition that the human organism has a reduced capacity as an effect of sin. It may be compared to disease; though not itself sin, it is a consequence or complication of the fall. While perceptual differences indicate a problem of knowing, it is not necessarily a problem of thinking, and certainly, it is not a problem of doing.

The cogitative processes which involve the active thinking or contemplative functions of the mind have been changed as well. These thinking processes involve what humans allow their minds to dwell upon. Conflict entertained here is far more than merely a perceptual difference. Certainly, perceptual differences may lie at the base of cogitative thinking, but at this level of thinking these perceptual differences are nurtured, dissected, and reconstructed by the active thinking processes. It is akin to prurient (lascivious) thoughts in the sexual area. Prurience is more than a function of perception (perceiving that two people differ biological1y), it is an active thinking of prurient thoughts about one's own sexuality or another's sexuality.

Dwelling on lustful thoughts results in awakening and nurturing certain emotions (e.g., desires, passions, 
etc.) that may eventually lead one to commit a lustful act. Likewise, dwelling on discordant thoughts results in awakening and nurturing certain emotions (e.g., anger, bitterness, fear, etc.l that may eventually lead one to engage in discordant behavior.

This link between the cogitative process and overt behavior works in reverse as well.1 The discordant actions that reflect discordant thoughts in turn feed new discordant thoughts. Actions that produce disintegrating interpersonal relationships reinforce one's perception that produced the discordant actions in the first place and this in turn produces yet more discordant behavior.

The distinction that this theological model of conflict makes between perception, cogitation, and overt behavior is helpful for several reasons. First, on the basis of theological reflection it provides an understanding of conflict that allows the church not only to accept the presence of conflict but to welcome conflict in certain cases. Whether it is referred to as human limitations or perceptual differences, the fact remains that Christians often view situations differently. The differing viewpoints that result from differing perspectives should be welcomed as an opportunity of seeing a fuller representation of reality.

This position also seems to be supported by

${ }^{1}$ Alan C. Filley, Interpersonal Conflict Resolution (Glenview, Ill.: Scott, Foresman and Co., 1975), p. 8 . 
Pauline theology of the church as the "body of Christ."1 It not only recognizes great diversity within the church, but it also stresses that this diversity is God-ordained and works for the benefit for the whole. It seems as though the health, stability, and growth of the church organism is related to the way its diverse parts (or members) interrelate. ${ }^{2}$ Therefore, the problem as Paul sees it is not that the body is diverse in nature but how its various members relate to each other in their diversity.

Second, if the presence of differing perspectives is recognized as a valuable resource for the church that also has the potential for distructive conflict, then the concerned Christian leader will wish to develop an atmosphere in the church where differing opinions are welcomed and respected while at the same time avoiding corrupted thoughts. It is the thesis of this project that such an atmosphere can be developed in a congregation whereby people can engage in constructive disagreement over facts, methods, goals, or values without experiencing the complication of disintegrating human relationships, evil thoughts, or acts.

Third, the theological conceptual model also teaches that there is a potential for discordant behavior

\footnotetext{
11 cor $12: 27$.

$2_{\text {Eph } 4: 11-16 .}$
} 
that can result in disintegrating human relationships. The Christian leader, then, would need to incorporate into his/her conflict-management strategy a process that would reconcile those who might become estranged by discordant behavior.

The biblical theme of reconciliation holds this hope. It is first seen as a work of God to bring man to himself. 1 That is, God acted to break down the dividing wall by initiating mankind's redemption by inaugurating reconciliation. 2 This has resulted in replacing hostility with peace between God and man. 3 However, reconciliation is not just an activity of God. That is to say, God has also given the "ministry of reconciliation" to those reconciled to him. 4

The implication is that reconciliation must take priority in the context of a conflict between Christians. If a Christian leader is to be guided by this principle, then he/she will give priority to interpersonal relationships and the restorative nature of reconciliation.

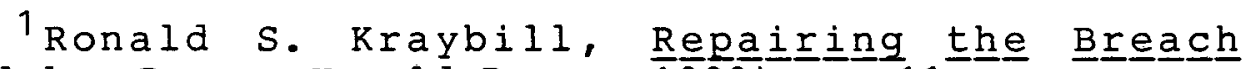
(Scottdale, Penn.: Herald Press, 1980), p. 11.

${ }^{2}$ Eph 2:14-16.

${ }^{3} \operatorname{Col} 1: 20$.

${ }^{4} 2$ Cor 5:18-19. See also Donald E. Bossart, Creative Conflict in Religious Education and Church Administration (Birmingham: Religious Education Press, 1980), pp. 130-133; Buzzard and Buzzard, pp. 10-12; Buzzard and Eck, pp. 51-52; Kraybill, pp. 12-14. 


\section{Conclusions}

The theology of conflict discussed above appears to have acknowledged the positive elements of the three views of the origin of conflict discussed earlier in this chapter while at the same time avoiding their negative aspects. For instance, the first view lconflict originated with sin) acknowledges that sin has had an effect on the development of conflict. However, the above theology does not share the opinion that conflict itself is sin. Instead, it prefers to see conflict as a sum of various parts not all of which can be considered sinful.

It is at this point that there is common ground with the second view of conflict (conflict results from human limitations). For instance, one of the ingredients in the conflict model is the perceptual limitations of the human mind. However, while the second view emphasizes a manward approach, tracing limitations to the natural state of being human, the above theology seeks to understand human limitations first as God intended in his perfect creation and then as sin has degraded them. It seems that the error of the second view is that it minimizes the role that sin has played in the developmental aspects of conflict. If one minimizes the role that $\mathrm{sin}$ has played in the development of conflict, it would follow that one could also minimize the role redemption plays in the management or resolution of 
conflict. The Christian leader must call to mind mankind's spiritual dimension (creation, fall, and redemption) as he/she determines the kinds of approaches (administrative and/or organizational strategies) selected and used in conflictive situations. 
CHAPTER TWO

THEORETICAL CONSIDERATIONS THAT UNDERLIE

A STRATEGY OF CONFLICT TRAINING

\section{Introduction}

The thrust of this chapter is toward the development of a strategy that will underlie a process of educating church members in certain conflict management skills that will potentially enable them to maintain functional interpersonal relationships while they search for mutually acceptable solutions in conflictive situations.

Toward this end, this chapter first briefly considers recent trends in conflict theory and explores three widely held assumptions about conflict that have a bearing on the conclusions of this chapter. Second, educational sources are explored in order to develop a theoretical base for learning. Third, two approaches widely available to church groups for the purpose of teaching conflict management principles from a Christian perspective are analyzed. Finally, an educational philosophy is developed taking into account the foregoing material. 


\section{Conflict Theory in Current Literature}

In order to adequately understand the thinking and assumptions of those presently writing on the subject of conflict, it is first necessary to briefly review some recent trends in conflict theory.

\section{Brief review of recent}

\section{trends in conflict}

\section{theory}

It should first be noted that it is commonly held among conflict theorists that every society has developed some mechanism for resolving conflict. 1 This is recognized to be the case whether that society is considered primitive or technologically and socially advanced.2 However, at neither pole nor in the continuum of societies can one speak of a singular mechanism used to resolve all conflict. Instead, a society has a plurality of mechanisms each influenced by certain dynamics within society such as its legal, cultural, political, moral, and religious structures. This plurality of mechanisms is a reflection of the kind of pluralism and diversity inherent within society itself. The result is that social scientists find it difficult to generalize about how a specific society resolves

${ }^{1}$ Nelson A. Watson, Issues in Human $\underline{\text { Re }}$ lations (Gaithersburg, Md.: International Association of chiefs of Police, 1973), pp. 19-20.

${ }^{2}$ Rensis Likert and Jane Gibson Likert, New Ways of Managing Conflict (New York: MCGraw-Hill, $1 \overline{976}$ ), p. 15 . 
conflict. The best that can be said is that a study of a society's formal organizations may give some insight to the student as to how certain groups within a given society resolve or manage conflict.

What is clear, however, is that the strategies and principles for dealing with conflict used by various organizations within society generally reflect the basic values and philosophy of that society. If this is the case, then one would expect that if the values and philosophy of society change, one would see a corresponding change in the strategies and principles for dealing with conflict. 1 This seems to be the thinking that marks the recent trend in conflict management theory. 2

A number of factors at work in the twentieth century have directly or indirectly influenced the values and philosophy of society. These factors include the development of the formal discipline of organizational sociology, the human relations movement referred to as Organizational Development (OD), and the

${ }^{1}$ Likert and Likert, p. 14. "Research in these organizations which brings improvement in their organizational theory and management systems brings with it corresponding improvement in the way conflict is managed" (p. 15).

2 The current trend in conflict theory is traced to Lewis A. Coser who published his book (The Functions of Social Conflict [New York: Free Press, 1956 ; London: Collier-Macmillan, 1956]), in 1956. Interestingly, Coser draws heavily from conflict theories espoused by the turn-of-the-century German sociologist Georg simmel. Simmel presents a strong case for conflict as a functional part of the social process. See also King, p. 14. 
business-management movement which has produced Management by objectives (MBO). 1 one thing that has resulted from the research and theories of these groups is a dramatic change in how conflict is perceived and handled. The changes introduced in conflict strategies as a result of the work of these disciplines is discussed by George F. Wieland and Robert A. Ullrich in their college text, Organizations: Behavior, Design, and Change. These authors see three stages in the development of conflict theory. 2 They refer to the first stage as the "rational, classical approach" to the management of conflict. This approach views conflict as undesirable and, hence, it teaches that the organization should be designed and managed in such a way that 1 imits conflict. The second stage is the "organic or open-system model" which sees conflict as a "temporary disequilibruim to be rectified." stressing the "dynamic homeostasis" view of conflict, this approach holds that "conflict between the system and its environment is ameliorated through adaptation." The final stage is the "human relations approach" which recognizes not only the continuing existence of conflict but also its importance. Further, Weiland and Ullrich suggest that this last approach has lately made a further adaptation. While this approach was also originally

${ }^{1}$ Hutcheson, pp. 45-46.

2(Homewood, I11.: Richard D. Irwin, 1976; Arundel, Sussex: Irwin-Dorsey International, 1976), p. 269. 
concerned with the reduction of conflict, certain views of motivation now indicate that mild levels of conflict in an organization may be more desirable than the complete eradication of conflict taught by earlier approaches. ${ }^{1}$

Likert and Likert provide a helpful model illustrating the changes that have recently developed in management. ${ }^{2}$ They plot the characteristics of management on a continuum of one to four--"from structurally rigid to open, responsive systems." 3 According to Likert and Likert, primitive societies tend to rely on the punitive treatment of its members (System 1) while at the other end of the continuum (System 4 ) the supportive treatment and involvement of the members in an organization is emphasized. ${ }^{4}$

Likert and Likert's model illustrates the dramatic shift that has taken place in the theory and practice of

${ }^{1}$ Wieland and Ullrich, p. 269.

${ }^{2}$ Likert and Likert, p. 18.

${ }^{3}$ Kurtz, "The Pastor and Institutionalization," p. 217.

${ }^{4}$ Likert and Likert, p. 19. A brief description of System 4 follows: "The human organization of a System 4 firm is made up of interlocking work groups with a high degree of group loyalty among the members and favorable attitudes and trust among peers, superiors, and subordinates. Considerations for others and relatively high levels of skill in personal interaction, group problem solving, and other group functions also are present. These skills permit effective participation in decisions on common problems. Participation is used, for example, to establish organizational objectives which are 
management. Whereas earlier approaches considered conflict harmful and dysfunctional in achieving organizational objectives and to be avoided, ${ }^{1}$ conflict has now largely come to be seen as pervasive in human relationships and perhaps even necessary in organizations. ${ }^{2}$ Whereas literature once emphasized conflict resolution, literature now emphasizes conflict management. ${ }^{3}$ whereas managers once avoided conflict at all costs, now managers are taught to welcome certain kinds of conflict as an opportunity for innovation, for

a satisfactory integration of the needs and desires of all the members of the organization and of persons funtionally related to it. Members of the organization are highly motivated to achieve the organization's goals. High levels of reciprocal influence occur, and high levels of total coordinated influence are achieved in the organization. Communication is efficient and effective. There is a flow from one part of the organization to another of all the relevant information important for each decision and action. The leadership in the organization has developed a highly effective social system for interaction, problem solving, mutual influence, and organizational achievement. This leadership is technically competent and holds high performance goals" (ibid., p. 16).

1 Anant R. Negandhi, Conflict and Power in Complex Organizations: An Inter-institutional perspective (Kent, Oh.: Comparative Administration Research Institute of the Center for Business and Economic Research as the College of Business and Administration of Kent State University, $1972)$, p. 7 .

2 Wieland and Ullrich, p. 269. "The human relations approach [to management], growing out of the classical and rational theories, recognizes the continuing existence and great importance of conflict and seeks to reduce its toll on members of the organization."

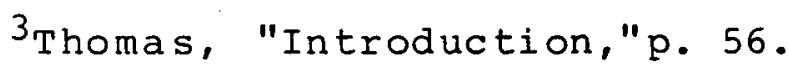


the clarification of organizational goals, ${ }^{1}$ and for intimacy. ${ }^{2}$ Whereas differences were once smoothed over, now managers are encouraged to confront differences. ${ }^{3}$

In this vein, notice Folger and Poole's analysis of the current trend:

Trainers, counselors, consultants, and authors of conflict textbooks point to the potential positive functions of conflict: conflicts allow important issues to be aired; they produce new and creative ideas; they release built-up tension; they can strengthen relationships; they can cause groups and organizations to reevaluate and clarify their goals and missions; they can also result in 4 social change to eliminate inequities and injustice. 4

Assumptions of conflict that relate to this paper

There are certain assumptions about conflict that have led theorists to the above conclusions. Three that are commonly held by conflict theorists and that also underlie the approach in this paper, are as follows:

Prevalant nature of conflict. Both technical and popular literature teach that conflict is an inevitable feature of human social life. ${ }^{5}$ Conflict is seen as a

${ }^{1}$ Webber, p. 446 .

2 Hoff, p. 17.

${ }^{3}$ Richard E. Walton, Interpersonal peacemaking: Confrontations and Third-party Consultation (Reading, Mass.: Addison-wesley Publishing Co., 1969), p. v.

${ }^{4}$ Working Through Conflict (Glenview, Ill.: Scott, Foresman and Co., 1984), p. 1 .

${ }^{5}$ See respectively Cosier and Ruble, p. 816, and 
pervasive phenomenon both within and between individuals (intrapersonal and interpersonal conflict) ${ }^{1}$ and within and between groups (intragroup and intergroup conflict) as well as within organizations. ${ }^{2}$

Since the church is an organization composed of humans, it should not be surprising to find that conflict thrives there as well. Church members and leaders may wish to ignore or avoid it, but as Savage says, "Only the innocent and naive would assume that, as Christians working in the church, they would never get into a conflictive setting." Further, he notes that "Regardless of how hard you try to avoid it, conflict will be your companion in church work." 3

If conflict is the inevitable companion of church leaders, then leaders would do well not only to study the dynamics of conflict but also to learn effective intervention strategies.

Functional and dysfunctional conflict. A number of theorists tend to view conflict as having the potential of being either functional or dysfunctional--

Hugh Doherty, "Management Strategies: Constructive Conflict," Dental Management 24 (December 1984):62.

${ }^{1}$ Leas and Kittlaus, p. 29.

$2 \mathrm{~J}$. David Hunger and Louis W. Stern, "An Assessment of the Functionality of the Superordinate Goal in Reducing Conflict," Academy of Management Journal 19 (December 1976):591.

${ }^{3}$ Savage, p. 42 . 
constructive or destructive. ${ }^{1}$ For example, walton lists

five possible constructive consequences of conflict.

First, it may increase the motivation and energy available to do tasks required by the social system. Second, conflict may increase the innovativeness of individuals and the system because of the greater diversity of the viewpoints and a heightened sense of necessity. Third, each person may develop increased understanding of his own position, because the conflict forces him to articulate his views and to bring forth all supporting arguments. Fourth, each party may achieve greater awareness of his own identity. Fifth, interpersonal conflict may be a means for managing the participants' own internal conflicts. 2

Walton also points out that conflict can be destructive in that it can "rigidify the social system" and can "lead to gross distortions of reality." 3

The fact that conflict has the potential of either

${ }^{1}$ Raymond $W$. Mack and Richard C. Snyder seem to characterize these two--functional and dysfunctional conflict--as alternative views or approaches to conflict. However, most authors seem to link these as alternative results of conflict. This, incidently, seems to be the position to which Mack and snyder finally subscribe. "The Analysis of Social Conflict--Toward an Overview and Synthesis," in Conflict Resolutions: Contributions of the Behavioral Sciences, ed. Clagett G. Smith (Notre Dame, Ind.: University of Notre Dame Press, 1971), pp. 4, 1617. See also Morton Deutsch, The Resolution of Conflict (New Haven: Yale University Press, 1973: repr int ed., Binghamton, New York: Vail-Ballou Press, 1978), pp. 8-10; Savage, pp. 42-43; Folger and Poole, pp. 5-7.

2 Walton, p. 5. Kurtz lists three additional positive functions of conflict: (1) "conflict may help to sharpen the issues and enable people to distinguish more clearly between two points of view"; (2) "conflict enhances the principles of democracy and freedom"; and (3) conflict may be a means of "hastening change." "The Pastor as a Manager of Conflict in the Church," p. 114116.

3 Walton, p. 5 . 
functional or dysfunctional results is as real in a church setting as in a secular setting. The appearance of numerous titles in the bibliography of this paper, which feature conflict ministry in the church, tends to substantiate this view.

The fact that conflict has the potential of either or both constructive and destructive results leads one to wonder if it is possible to manage conflict in such a way as to influence its outcome.

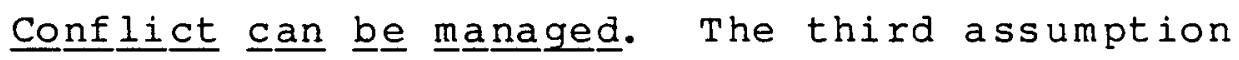
about conflict, widely held by theorists, is that conflict can be managed so as to influence its outcome by decreasing its negative effects and increasing its positive results. This is not to say that one can manage conflict so as to guarantee a positive outcome in every case. Rather, it is first a recognition that conflict does not generally resolve itself, and therefore a Christian leader must of necessity learn to creatively manage conflict. 1 Second, it is also a recognition that the creative management of conflict can influence its outcome.

Not only is it widely held that human conflict is inevitable, but it is also widely assumed that humans have the capacity to influence and shape, within the

${ }^{1}$ Hoff, p. 16 . 
realm of human interaction, whether conflict will be destructive or constructive. 1

\section{Summary}

It is precisely here that one can see both the hope and challenge of conflict, especially as it relates to the church. The hope is that conflict need not lead inevitably to disintegration in human relationships and to organizational dysfunction. The challenge is that church leaders need to act intentionally in the face of conflict so as to influence its outcome toward the positive.

Unfortunately, by and large, neither the membership nor the clergy are well equipped to handle conflict. Concerning the clergy, Kurtz says that they have not dealt effectively with conflict because "successful management of conflict requires administrative skills and a considerable knowledge of organizational strategies, neither of which has generally been given very high priority." 2

Though Kurtz fails to indicate who is responsibile for setting these priorities, certainly clergymen have some choice as to their continuing professional enrichment and, therefore, bear some responsibility in

${ }^{1}$ Lewis, pp. 1-2. 111.

2 Kurtz, "The Pastor as a Manager of Conflict," p. 
acquiring these shills. Others who might have some control over a pastor's continuing enrichment would be those professionals responsible for structuring programs for the continuing education of the clergy. These professionals need to give priority to offering such instruction that would help clergy deal with conflict in a professional manner.

Congregations also seem to lack the skills for dealing with conflict. This fact is obvious from the many church conflicts that end with destructive results. The observation that clergy and laity both handle conflict so poorly has led Leas and Kittlaus to espouse the use of a third party trained in conflict intervention. Leas and Kittlaus believe that the development and use of such professionals will lead to the "best and longest-lasting result of conflict management." 1

If Kurtz and Leas and Kittlaus are correct, then there is the need for instructional materials that will inform both pastors and laity in conflict concepts. In addition, these materials should develop certain interpersonal skills that will minimize the negative effects of conflict while maximizing the potential for positive change and growth that can come in the wake of conflict. The question is, what type of instructional

${ }^{1}$ Leas and Kittlaus, p. 54 . 
materials and learning experiences results in changed behavior?

\section{Theoretical Base for Learning}

To answer the above question, it is necessary to explore the meaning and process of learning. Any program that has as its stated purpose not only the dissemination of information but also the hope of changing human behavior must be built on sound instructional principles. Those in educational circles hold that instructional success includes more than merely cognitive learning. Robert F. Mager highlights the importance of behavior in the learning process thus: "If instruction doesn't change anyone, it has no effect, no power."1 This change, however, must be focused and have direction; it is not random change merely for the sake of change. Mager adds that if instruction results in undesired change, then "it is called poor, undesirable, or even harmful instruction." 2

In the same vein, Martha M. Leypoldt writing on the subject of education in a church setting says, "When a person has learned, he is a changed person: he is

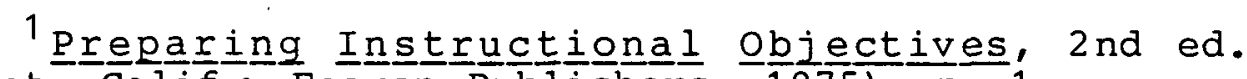
(Belmont, Calif.: Fearon Publishers, 1975 ), p. 1 .

2 Ibid.
} 
transformed."1 After quoting Rom 12:1-2,2 Leypoldt further notes that it is especially appropriate to speak of "change" in a Christian context because scripture calls for productive change. ${ }^{3}$

According to these two authors, the objective of instruction is not merely the dissemination of information on the cognitive level, but it is ultimately concerned with change toward a desired and predetermined direction in the one learning. According to Leypoldt, these changes include changes in knowledge, in feelings, and in action. 4 other educators refer to cognitive and affective learning. Cognitive learning has to do with acquiring knowledge and skills while affective learning has to do with the changes in attitudes and feelings. 5 For these educators, complete learning takes place as both the cognitive and affective processes are postively affected. Press, $19 \frac{1}{971} \frac{\text { ean }}{1}, \frac{\text { ing }}{\text { p. }} 27$. Change (Valley Forge, Pa.: Judson 2 "Therefore, my brothers, I implore you by God's mercy to offer your very selves to him: a living sacrifice, dedicated and fit for his acceptance, the worship offered by mind and heart. Adapt yourselves no longer to the pattern of this present world, but let your minds be remade and your whole nature thus transformed" (Rom 12:1-2 [NEB]).

${ }^{3}$ Leypoldt, p. 27 .

${ }^{4}$ Ibid.

${ }^{5}$ Doris T. Gow, ed., Design and Development 으르 Curricular Materials, vol. 2 (Pittsburg: University Center for International studies, 1976), p. 267. 
This concept seems to be accepted both in secular and in religious education. For instance, Bossart points out that

We are after not only the cognitive skills, but the emotional maturity which is the affective developmenf in the growth of the student in religious education.

This affective development lor, "emotional maturity" as Bossart refers to it) is seen as the basis for responsible behavior.

Richard C. Remy prefers the term "citizenship competencies" which he uses with much the same meaning. He defines it as

- . the particular capacities an individual (sic) requires if they are to behave in such a way, or use their efforts in such a manner, as to produce consequences they intend in their role as citizens. 2

Remy lists the kinds of competencies that are to be developed through the educative process: acquiring and using information, assessing involvement, making decisions, making judgments, communicating, cooperating, and promoting interests. 3 It must be recognized that these competencies evolve from the learning that takes place in the cognitive and affective processes.

If this is true, then it seems clear that the goal

${ }^{1}$ Bossart, p. 155 .

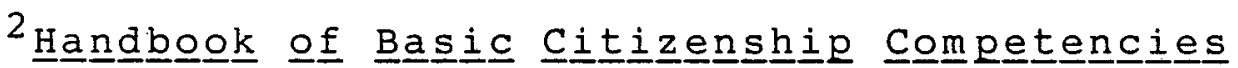
(Alexandria, Va.: Association for Supervision and Curriculum Development, n.d.), p. 15 .

${ }^{3}$ Ibid., pp. $3-4$. 
of instruction is in some way to shape behavior. It would also seem reasonable to suggest that behavior can be shaped by intentionally. structuring instruction with that in view. James Michael Lee seems to agree with this point of view when he says, "teaching consists in the deliberate, conscious structuring' of a learning situation so that the desired learning outcomes are effected."1

Interestingly, this emphasis on structuring the learning experience appears to represent a shift in educational philosophy to the consideration of the needs and experience of the student. The "structuring of a learning situation" is the process of leading the learner through various experiences that culminates in learning. Notice the emphasis that Ralph $W$. Tyler places on the experience of the learner in the process of learning when he says, "Essentially, learning takes place through the experiences which the learner has: that is, through the reactions he makes to the environment in which he is placed." 2 For Tyler, the means of education become what he refers to as "educational experiences" which are had by the learner. 3

${ }^{1}$ The Shape 으 Religious Instruction (Mishawaka, Ind.: Religious Education Press, 1971), p. 59.

${ }^{2}$ Basic Principles of Curriculum and Instruction (Chicago: University of Chicago Press, 1949; reprint ed., Chicago: University of Chicago Press, 1975), p. 63.

3 Ibid. 
Tyler calls this the "learning experience."1 This refers to the interaction between the learner and the external condition in the environment to which he can react. ${ }^{2}$ Learning, then, for Tyler takes place through the active behavior of the student; it is what he does that he learns, not just what the teacher does. ${ }^{3}$ The teacher provides the educational experience by setting up an environment and structuring the situation so as to stimulate the desired type of reaction. ${ }^{4}$

If Tyler's reasoning is correct, then it would follow that an educational program that is designed to achieve certain given objectives--both cognitive and affective--must not only consider the kind of information that is be taught but must also give priority to the structuring of educational experiences that engage the learner in the process of learning. 5

It seems clear, then, that if the end product of

$$
\begin{aligned}
& { }^{1} \text { P. } 63 . \\
& { }^{2} \text { Ibid. }
\end{aligned}
$$

3Ibid. See also Robert Glaser, "Learning," in Design and Development of Curricular Materials: Instructional Design Articles, ed. Doris T. Gow (Pittsburgh: University Center for International Studies, 1976), p. 82. "The learner acts upon his instructional environment, changes it, and is changed in turn by the consequences of his actions. Certain processes alter behavior so that it achieves a useful interchange with a particular environment."

$$
\begin{aligned}
& { }^{4} \text { P. } 64 . \\
& { }^{5} \text { P. } 63 .
\end{aligned}
$$


learning is to be exhibited by the kinds of changes made in the learner's behavior, instructional objectives should be written as a description of the kind of performance the instructor wants the learners to be able to exhibit. In other words, objectives are a description of an intended result of the instruction, rather than a description of the process of the instruction itself.' This is not to say that process is not important in the learning, rather, it recognizes that processes must be chosen by the instructor to either initiate or reinforce certain desired behaviors. ${ }^{2}$

In conclusion, it would seem that the proper development of a program designed to change the way people behave in conflictive situations would be: (1) to develop a set of objectives based on the kind of behavior Christians should exhibit in conflict ${ }^{3}$ and (2) to develop instructional situations that lead the learner to experience and integrate new reactions to conflictive situations.

\section{Analysis of Two Conflict Curricula}

Two curricula, available to churches. for the purpose of developing conflict awareness in a seminar

${ }^{1}$ Mager, p. 5 .

2 Ibid.

${ }^{3}$ See chapter 3 for a statement of the instructional objectives. 
setting, are presented here. Certainly other programs also available could be considered, but these two were chosen because of their availability and because they appear to be representative of attempts to develop a curriculum on conflict management from a Christian perspective.

\section{"Resolving Our Differences" \\ curriculum}

The Resolving Ouㅗㅡ Differerences curriculum is a joint effort of Lynn Buzzard, Juanita Buzzard, and Laurence Eck. Lynn Buzzard is the executive director of the Christian Legal Society; ${ }^{1}$ Eck is a practicing 'attorney who shares similar views to the society; and Juanita Buzzard is a Christian education director at western springs Baptist Church, Western springs, Illinois.

Description of the curriculum

The three components of this curriculum are: a

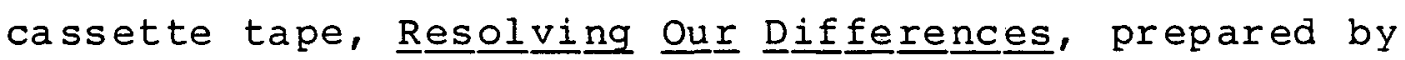

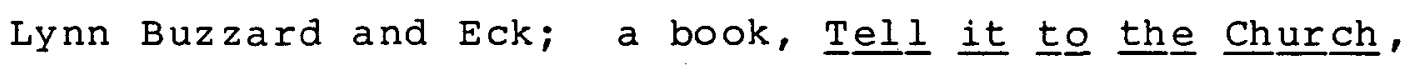
written by Lynn Buzzard and Eck; and a manual of Christian training materials, Resolving Our Differences,

${ }^{1}$ The Christian Legal Society is a network of evangelical lawyers which provides mediatorial or arbitrational services in several metropolitan areas nationwide as an alternative to litigation in the courts. The Christian Conciliation Service is one of the services it offers. 
prepared by Lynn Buzzard and Juanita Buzzard.

The cassette tape--Resolving Our Differences. The cassette tape features a discussion between Lynn Buzzard and Eck that centers primarily on the biblical teaching of reconciliation and how this teaching can be applied in a church setting to settle disputes. The church, they say, has a responsibility to settle disputes that develop within the congregation. In Buzzard's words:

Disputes are the property of the Church. The church really owns these disputes. The courts don't own them. The secular counseling profession doesn't own them.1 This is right at the heart of the church's ministry.

A number of examples are cited to demonstrate the positive and satisfactory results that can develop when those involved in a dispute seek to settle their differences in accordance with what Buzzard and Eck describe as "biblical principles." Not only are the issues or elements that led to the dispute resolved, but the parties experience a reconciliation marked by healing and the restoration of relationships. They claim that this is the purpose of the church and for which the courts are not equipped. 2

The concluding comments of Buzzard and Eck concern what they believe should develop in churches that become

${ }^{1}$ Resolving Our Differences, Cassette tape available from David C. Cook, Elgin, Ill., 1982.

2 Ibid. 
aware of the biblical teaching of reconciliation. First, they suggest that those who have themselves experienced conflicts in their personal lives become resource and support persons to act as "wounded healers" for those currently experiencing similar difficulties. Second, they suggest that leaders in the church should become equipped and prepared to deal with conflict and disputes. They further suggest that leaders should handle disputes through a structured ministry of peacemaking just as there is a ministry of stewardship in many congregations. Third, the church should seek to implement some preventative measures such as teaching the biblical principles of peacemaking, structuring a ministry of peacemaking, and encouraging covenanting or contracting between members of a congregation so that if a dispute should arise they would submit it to the church for resolution rather than to a court.

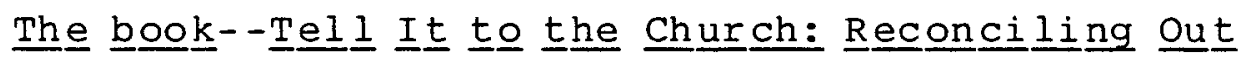
of Court. Lynn Buzzard and Eck continue a similar approach in their book, Tell It to the Church: Reconciling 은 으 으모. Basically, the book promotes the fundamental principles championed by the Christian Conciliation Service which aims to resolve disputes between Christians in the church setting rather than in the courts.

Buzzard and Eck point out that the courts are 
being used more frequently to settle disputes because "many of the primary social structures (extended family, neighborhood groups, social organizations), which in an earlier generation absorbed much of the interpersonal conflict" are now gone. 1 However, as Buzzard and Eck point out, one social structure that still is present in society is also best equipped to deal with conflict and that is the church.

Christian doctrines and convictions are almost custom-made for conflict resolution and healing: the doctrine of reconciliation, the doctrine of forgiveness, and the doctrine of the covenant and its application in restoring broken relationships. The church is the gifted and equipped body of Christ. ${ }^{2}$

The book features successful instances of when reconciliation worked, a discussion of the theological basis of peacemaking, and an appendix of resource material that may prove helpful to churches attempting to set up a reconciliation service.

The manual--Resolving Our Differences. The manual written by Lynn and Juanita Buzzard is the heart of the curriculum package. It contains lecture material, lesson plans, suggested material for further study, suggested discussion questions, transparencies for overhead projection, and duplicating masters ready for use.

The material is designed to be used in a group

${ }^{1} \mathrm{P} .12$.

${ }^{2}$ Buzzard and Eck, p. 15. 
setting and is based on Bible study and group discussion. The stated goal of the material is to

- - acknowledge the reality and scope of conflict, examine the biblical call to a converted way of dealing with disputes, and to see the opportunity that conflict offers for the church to exercise its bibliçally mandated gifts of healing and reconciliation.

The material is divided into eight sixty-minute sessions, and it is suggested that the sessions be separated by a week to allow for reflection as well as between-session assignments. The sessions' titles and themes are as follows:

Session One--"Conflict: It's Inevitable and O.K." The student is challenged to examine his/her understanding of conflict by accounting for both the negative and positive results that can come from conflict, by considering five conflictive situations in the New Testament, and by analyzing various types and sources of conflicts.

Session Two--"Responding to Conflict." The student identifies the five possible responses to conflict situations and is encouraged to consider not only which is his/her response style but to adjust those styles if they are out of character with Christian values.

Session Three--"Forgiveness--Forgive and Forget." The student is encouraged to see forgiveness as a bibli-

${ }^{1}$ Buzzard and Buzzard, p. 1 
cally mandated. response to conflict. As such, forgiveness is not conflict avoidance but, rather, a proactive response to conflict. Forgiveness offers to set aside the right of judgment, vengeance, and payment for the purpose of healing and reconciliation.

Session Four--"Reconciliation." By exploring the biblical principle of reconciliation, it becomes clear that in the context of conflict situations more is called for than simply the resolution of a dispute. Biblically speaking, reconciliation reestablishes disintegrating interpersonal relationships to wholeness.

Session Five--"Tell It to the Church." The student is encouraged to see the biblical role of the church in the process of reconciliation. That is, only the church is empowered by God to engage effectively in peacemaking. If this is the case, then points of dispute should be submitted to the church for resolution so that reconciliation of antagonists can take place.

Session Six--"The Church as Peacemaker." Whereas the previous session explored the fact that the church is the vehicle of creating peace and healing conflicts, now the ingredients that make the church so equipped are brought to view.

Session Seven--"Blessed Are the Peacemakers." The student is challenged to look at the kinds of gifts and skills that are necessary to be a peacemaker. Basically, 
these skills are delineated in the way Jesus handled conflict.

Session Eight--"Agents of Reconciliation." In the final session, the student explores the meaning and process of arbitration with the encouragement that if he/she is so equipped he/she will become an agent of arbitration within the church setting.

Analysis of the curriculum

The manual containing the lecture material, transparencies, and duplicating masters is the center of the curriculum package. The material seems to be carefully arranged to take advantage of current learning theory. For instance, processes such as group discussions, inductive studies of scripture, feedback sessions and reflective-at-home assignments are designed to encourage learner involvement. By encouraging the learner to participate in the learning process, this curriculum seeks to accomplish both cognitive and affective learning. One may question, however, the direction they choose to take in their material.

The curriculum package under discussion evolved as a result of the needs and concerns addressed by the Christian Legal Society. The nature of these needs and concerns are clearly outlined in both the book, 티르 I to the Church, and the cassette, Resolving Our Differ eㅡㅡ트으. Basically, Lynn Buzzard and Eck approach 
conflict in the church from a legal/arbitrational viewpoint. That is, they see many Christians who are engaged in disputes going to the court system for settlement. Buzzard and Eck argue that the Christian should not go to the courts but instead to the church for arbitration. The reason, they argue, is that the church is better equipped to handle disputes because of divine insight given by the Holy spirit and because the church is empowered to bring not only resolution but also to effect reconciliation.

Also, the material of Buzzard and Eck is based on the premise of a third-party arbitration model. In their view, either that arbitrator is the court system or the church system. Certainly, there are many cases where arbitration is necessary and, perhaps, even essential. However, one wonders if the mechanism proposed by Buzzard and Eck may in the end cause members to be even more dependent on a third party to resolve conflict rather than developing interpersonal skills that may allow them to settle the issue themselves.

It appears that Buzzard and Eck have been driven to this viewpoint because of their overriding concern about Christian litigation in the courts. Certainly, based on this concern, they have developed a package that has the potential of meeting the need as they perceive it.

However, the need they are addressing is not the 
need addressed in this project. Whereas, Buzzard and Eck are concerned with the type of conflict that arises from business dealings and contractual relationships, this project is concerned with perhaps more minor, albeit more common, conflict that arises in every segment of interpersonal relationships. This type of conflict may never require a court or a third party for arbitration, but it does require certain common and simple skills that can turn a potentially destructive conflict into a constructive interchange.

"How to Manage Conflict in

the church" curriculum

The 브으 to Manage Conflict in the Church curriculum is authored by Norman Shawchuck, director of Spiritual Formation, Indiana area, of The United Methodist Church. Shawchuck also is an adjunct instructor at Trinity Evangelical Divinity School and at McCormick Theological Seminary. His interest in church management, which is evident in another recent work ${ }^{1}$ including the one under discussion, clearly flavors his approach to conflict and accounts for his strong emphasis on mangement concepts, such as intervention strategies, in dealing with conflict.

${ }^{1} \mathrm{Alvin} \mathrm{J}$. Lindgren and Norman Shawchuck, Man ment for Your Church (Nashville: Abingdon, 1977). 
Description of the curriculum

There are four components to this curriculum and

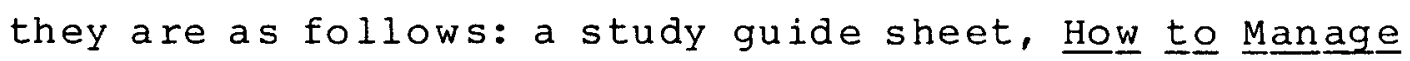
Conflict $\underline{\text { in }}$ the Church; a cassette tape; an analysis

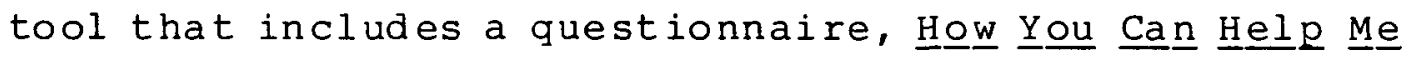
Manage Conflict More Effectively: a Self-Analysis Tool, a sample of a cover letter that accompanies the questionnaire, and a guide sheet to analyze the results of the questionnaire; and a manual in two volumes used for selfinstruction.

Unlike the previous curriculum that supplied a manual complete in itself with additional resource materials (i.e., the cassette tape and book) that certainly would prove helpful but not essential to the program, Shawchuck's curriculum materials are integrated and interrelated.

Though the materials are designed for selfinstruction, shawchuck encourages the formation of a small group for the purposed discussion and feedback. 1 However, since the materials are designed for selflearning, he states that each student must have his own set of materials and do his own study privately.

The study guide serves as a map or plan of the program of study. It details the subject of each session

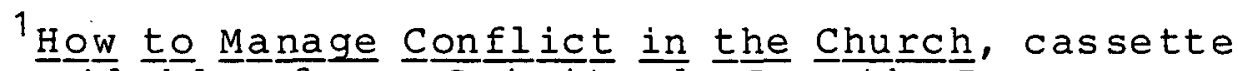
tape available from spiritual Growth Resources, Indianapolis, 1984. 
listing the pages to be read in the manuals, time needed for completion of the study, the extra materials needed (i.e., Bible, cassette tape player, paper and pencil), and a brief statement as to the study design for each session.

The cassette tape "talks" the student through each session giving background and introductory information about the materials to be studied or the exercises to be completed. If there is a heart to this program, it would certainly be this tape.

The program is divided into five sessions called "learning modules" of two and a half hours in length. Shawchuck suggests that these be covered over a period of about two weeks leaving from two to three days between sessions to allow for "reflection and mental digestion of the materials." 1 The sessions' titles and themes are: Session One--"Developing a Biblical Understanding of Conflict." The student first reads a written theology of conflict and then studies Acts 15:1-41 answering questions that guide him or her toward its meaning in terms of conflict.

Session Two--"Developing an Understanding of Your Conflict Behavior." The student answers questions on a questionnaire and scores himself or herself to find his

${ }^{1}$ Shawchuck, "A Guide to Using 'How to Manage Conflict in the church,'" an instruction sheet accompanying How to Manage Conflict in the Church. 
or her preferred style of handling conflict. The tape lecture discusses the meaning of the various styles and stresses that the conflict situation, should determine the style one chooses.

Session Three--"Understanding the Stages of Conflict and Their Effects upon Your Conflict Management styles." In this session, conflict management theory is introduced to help the student discover various ways of managing conflict at its various levels.

Session Four--"Designs and Skills for Managing Conflict." More conflict management theory is introduced to help the learner see the strength of various intervention strategies for various size groups.

Session Five--"A Review of Your Learning in the study of How to Manage conflict in the church." The student is led through a review and synthesis of the material presented.

The final step in Shawchuck's program is to solicit six persons in the church to fill out a questionnaire on the conflict-handling style of the student taking the program. After the results are collated, the student not only has a picture of how others view his/her style but he/she is also able to compare it with his/her own personal evaluation.

Analysis of the curriculum

This curriculum seems to have been developed for 
church leaders--pastors, administrators, committee chairpersons--who are responsible for guiding and directing the organization. Shawchuck's discussion of conflict theory and intervention strategies are particularly helpful for this group. By and large the material is prepared for individualized study. Allowances are made, however, for some group work but only for feedback and discussion; most of the material is to be studied on one's own. Because of these two points, the program seems most helpful for the motivated church leader who is anxious to discover ways of dealing with the conflict that may at times frustrate his/her work.

The key concept of shawchuck's program is the management of conflict. The skills that this program endeavors to teach are more suited for those who are in the role of leadership. The average congregation member who is more concerned about how to deal with interpersonal conflict than how to deal with conflict between groups on an administrative level would probably find the program inappropriate.

Perhaps a more substantial flaw in Shawchuck's curriculum as it relates to a theoretical base for learning is that his material appeals primarily to the cognitive processes (acquiring of knowledge and skills). In other words, he seems to assume that his readers have already acquired the attitudes and feelings (affective learning) necessary to integrate the knowledge and skills 
that he offers in his curriculum into a new behavior.

\section{Conclusion Concerning}

\section{Curricula}

Though both programs discussed may be beneficial for the groups for which they are intended, neither seems to meet the needs addressed by this project. Since this is the case, there is need for a program based on a strategy of cognitive and affective change that teaches simple interpersonal skills that will help the individual deal with the effects of conflict in such a way as to safeguard interpersonal relationships.

\section{Conclusions: An Educational Philosophy}

An educational philosophy may be likened to the foundation of a building; its shape determines the shape of that which is built upon it. While what follows is not meant to be a complete statement of the educational philosophy that undergirds this project, it is a suitable conclusion of the considerations of this chapter. From this material two foundational principles can be synthesized that have a bearing on the goals and objectives developed in chapter 3 .

\section{Education changes} behavior

Since the emphasis of this project is on the development of certain communication skils in the learner, it seems logical to assert that the goal of the 
educational process is not merely the dissemination of information but, rather, to devise a process that results in changed behavior. If this is the case, then the strategy of the educational process must be to use instructional procedures that enable the learner to translate concepts into action. This allows for a balance between information giving and certain other structured learning experiences such as role playing in small groups and reflection exercises. The latter are processes with which the learner interacts. Together these culminate in cognitive (knowledge and skills) and affective (attitudes and feelings) learning.

As important as learning experiences are, however, they must have focus if they are to have a desired effect upon the learner. If would appear that an educational strategy that is to result in behavioral change must aim at that which brings about change.

As was noted above, the basic values and philosophy of society affect the strategy and principles it uses for dealing with conflict. It was also noted that a change in the former results in a corresponding change in the latter; as the values and philosophy of society change, likewise, the strategy and principles it uses for dealing with conflict change. Since the church is a society, it should be expected to exhibit the same kinds of behavior as societies in general. Therefore, one can expect that as the basic values and philosophy of 
the congregation toward conflict change, likewise the way it deals with conflict will change.

How values might affect the way conflict is dealt with is illustrated by the fact that it appears as if the church prefers and, perhaps, even idealizes certain conflict management approaches over others. For instance, avoiding or ignoring conflict may be encouraged by certain values such as unity among the brethren ${ }^{1}$ or pacifism ("turning the other cheek").2 on the other hand, collaboration may be preferred because it implies a working together toward a mutually acceptable solution. In many situations, however, these approaches limit the church in its ability to deal with conflict, perhaps even making a resolution impossible. Also, if a nonpreferred conflict management style is inadvertently used (such as, compelling or competingl, then a feeling of failed expectations and disappointment with the system often ensues.

A teaching strategy, therefore, should give some attention to the restructuring of the values and philosophy that the people have regarding conflict. The goal is to develop a realistic understanding of the dynamics of conflict enlightened by theology and supported by current, compatible conflict theory so that

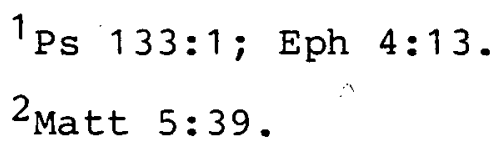


all of the various conflict management styles will be available for use depending on the situation.

\section{A Christian approach to} conflict values the person

A second educational principle that undergirds this project is that a Christian approach to conflict management will emphasize interpersonal relationships. As noted above, values shape the way conflict is managed. Further, however, Christian values have a unique regard for the preservation of interpersonal relationships. While Christians may hold an issue as important and may even disagree, they still give priority to relationships and the restorative nature of reconciliation. The educational processes used, then, must develop the concepts of conflict management in such a way that the learner will not only acquire the knowledge and skills necessary to manage conflict but also will adopt values that place a higher regard upon maintaining and/or restoring interpersonal relationships. 
CHAPTER THREE

DESCRIPTION OF THE PROJECT

\section{Introduction}

The presence of conflict within organizations and institutions is influenced by a number of factors: change, ${ }^{1}$ organizational structure, ${ }^{2}$ interdependence of working groups, 3 the availability of necessary resources, 4 and the use of power ${ }^{5}$ are some of the factors that relate specifically to the church. A meaningful description of this project certainly needs to take into consideration these factors as they may relate to the church and to the seminar participants. Therefore, the first two sections of this chapter are developed with this in view: 1) a description of the Ardmore Adventist Church, and 2) a description of the participants of the Conflict Skills Seminar. The final two sections are: 3)

1Johnson, pp. 16-17; Deutsch, p. 71 .

$2^{2}$ Deutsch, p. 77 .

${ }^{3}$ Webber, p. 445 .

${ }^{4}$ Ibid., p. 448 .

$5_{\text {Wieland and Ullrich, p. } 226 .}$ 
a description of the Conflict skills Seminar, and 4) a schedule of events.

\section{Description of the Church}

It is hardly possible to get a clear view of the Ardmore Adventist church without also looking at some of the major elements that affect it. Certainly, this would include such things as the institutions and services that the church provides, but it al'so includes the community of which the church is a part.

\section{The Community}

The town of Ardmore is situated on a gently rolling topography about thirty-five miles from the Oklahoma/Texas state Iine on Interstate 35 . It is the largest community between Oklahoma City to the north and the Red River to the south that forms the boundary between the two states. Within the city limits of Ardmore resides a population of 25,400 with an additional 66,500 living within a thirty-mile radius. Ethnically, the population parallels the rest of the state; 8 percent black, 5 percent indian, and 1 percent hispanic. ${ }^{1}$

The local economy is largely based on the production and refining of oil, manufacturing, and on

1 Interestingly, many of the local black persons can trace their migration as slaves of two of the five so-called "civilized" indian tribes (Chickasaw and Choctaw) that settled in what became the Ardmore area. These tribes were forced from their land in the southeast by the U.S. government in the mid-nineteenth century. 
various services offered in the public and private sectors. Although at first glance the countryside appears to be agricultural, the income to local inhabitants from farming and ranching is small in comparison to the major sources of income listed above. 1

Religion plays a major role in the lives of local inhabitants. There are seventy-one Protestant churches, one Catholic church, and one synagogue in the community. The strength of the religious influence is illustrated by the fact that due primarily to the resistance of the churches, the sale of liquor-by-the-drink was repeatedly voted down until it finally passed september 1985.

The citizens of Ardmore exhibit an independent flair that some attribute to the frontier spirit. For instance, this independence is perhaps witnessed by the fact that of the sixteen major local manufacturers only five are unionized. It may also be an element in the fact that local pastors have successfully resisted efforts to organize a local ministerial association. This desire for independence and autonomy may also be at the base of the suspicion and the lack of cooperation exhibited between the two local hospitals (Memorial Hospital and the Ardmore Adventist Hospital).

There is, however, a disarming sincerity and open

${ }^{1}$ Bureau of Economic figures indicate that personal income from farming/ranching for Carter county in 1980 was only $\$ 686,000$ compared to $\$ 82,782,000$ from manufacturing and $\$ 81,157,000$ from the oil industry. 
expression of hospitality exhibited by local residents that is quite winning. There seems to be on the surface a desire to be warm and affable. However, although people are generally open about their feelings regarding life's mundane experiences, many mask their feelings about the issues or problems that are causing them the deepest emotional pain.

When compared to other sections of the country, Ardmore might be characterized as a fairly stable community. Though change is present (the fluctuating oil market and sale of liquor-by-the-drink) the economic, political, and social structures do not seem to be experiencing threatening levels of change that often result in conflict.

\section{Church Institutions and Services}

\section{Ardmore Adventist Hospital}

The most influential Adventist presence in the community is certainly the Ardmore Adventist Hospital. Founded in 1946 as a nonprofit, self-supporting institution, it has sought to meet the health needs of the community as well as provide the church with a high community visibility.

In 1957, ownership of the hospital was assumed by the Oklahoma Conference of Seventh-day Adventists. The conference continued to operate the institution until 1979 at which time the administration--but not the 
ownership--of the hospital was transferred to the Adventist Health System/Sunbelt, part of the Adventist hospital network. The conference, however, continues to maintain three positions on the eleven-member board of directors; one of the positions is vice-chairman held by the conference president.

The hospital has seventy-two beds with an average census of thirty-two patients. Thirty-one of the 125 full-time equivalent employees are Adventists as are all administrators and most of the departmental directors. The hospital operates an aggressive health education program in the community that includes such programs as child birth, stop smoking, nutrition, and heartbeat classes. These are offered on a regular basis with most classes using church facilities.

Ardmore Sanatarium and Hospital Corporation Board

The Ardmore Sanatarium and Hospital Corporation Board was orginally the legal entity of the selfsupporting hospital founded in 1946. Though its assests were transferred to the Oklahoma conference in 1957, the corporation board continued to function primarily under the guidance and support of a local, prominent Adventist, otey Johnson. In 1984, new life was given to the corporation when Johnson bequeathed a substantial portion of his estate to the corporation.

The board is composed of five Adventists who have 
an interest in developing locally a health center operated separately from the church organization. Since this facility is likely to be patterned along the lines of the institutions developed at Weimar, California, and Rapidan, Virginia, 1 it is felt by the Ardmore Sanatarium and Hospital Corporation Board that it will not be in competition with but an adjunct to the Ardmore Adventist Hospital. Though there is the potential for friction and competition between this board and the Ardmore Adventist Hospital, the relationship has been one of cooperation. For example, the Ardmore Sanatarium and Hospital Corporation Board donated about $\$ 65,000$ during 1985 to the Ardmore Adventist Hospital for the purchase of medical equipment and other improvements.

The Ardmore Sanatarium and Hospital Corporation holds a number of properties in the Ardmore area including prime expansion property around the Ardmore Adventist Hospital. The corporation also holds some oil producing properties. However, its major source of income is from the otey Johnson Oil Producing Property Trust. This trust is managed by a five-member board on which three Adventists serve. The purpose of this board is to generate funds for the corporation.

${ }^{1}$ Weimar and Hartland Institutes, respectively. These centers stress preventative measures based on diet, exercise, and other "natural remedies" to ward off disease. 
Beavers Memorial Junior Academy

Beavers Memorial Junior Academy (BMJA) is a tengrade school operating in a rural location about five miles north of the church. During the school year 198586, thirty-four students were enrolled under three teachers: first through fourth grades, eleven; fifth through eighth grades, seventeen; and ninth through tenth grades, six students.

The facility which was built in the early seventies from funds donated by Nelle Beavers as a memorial to her late husband could easily accommodate twice its current enrollment. The size of the building is certainly a contributive factor that resulted in a non-tuition policy. By not charging tuition, enrollment was increased; it was reasoned that this was not only a better use of the building but that it provided a wider service to Adventist families who might have otherwise sent their children to public school. The cost of the school's operation is borne by the church and represents about 75 percent of the church budget.

As a consequence of this financial arrangement, the school board has diminished power; it no longer has control over the financial operation of the school nor over the process of setting up the school budget. Instead, budgetary items now are handled by the church finance committee. Therefore, the school board primarily 
concerns itself with policy matters and minor purchases that fall within the budgetary limits.

Kinder land House of aㅡㄹㅡ

While BMJA was under construction, classes were temporarily held in the church in order to free the old school structure for the development of a child-care center. The building is ideally suited for such a purpose. It is a three-classroom structure complete with kitchen located in town about three miles south of the church. Kinderland is licensed for eighty-one children and generally operates at capacity employing eight fulltime and three part-time employees. The church board is also the operating board for Kinderland and oversees various business matters including wages and child-care costs. The center donates $\$ 500$ per month to the operation of BMJA and has in the past at the will and discretion of the church board donated other money to BMJA for various improvements.

\section{Community Service Center}

The Community Service Center occupies a building around the corner from the child-care center. Though the structure looks like a house, it was built by the church in the late sixties for the specific purpose of housing the center. Since the hospital runs an aggressive community education program, the center limits its activities primarily to the distribution of clothing and 
food; ten volunteers help about 1,800 community people annually. Though technically the church board is responsible for the center's operation, there is little interchange between them. Instead, the tacit understanding is that the church pays the center's utilities and if other funds are needed, they are donated privately.

The Community Church

The black work in Ardmore is represented by the Community Church. The present structure was built prior to 1963 by donations from largely non-black sources. The church has not been able to flourish through the years and is currently closed. The few black Adventists in the community attend the white church.

Analysis of the Ardmore Adventist Church and the Potential for Conflict

The Ardmore Adventist Church with a membership of 300 is located on a quarter residential block at the north edge of town. The brick structure has a pleasant appearance; a high-peaked, sanctuary roof dominates the structure's appearance with the Sabbath School divisions and fellowship hall extending to the east.

The Adventist presence in the Ardmore community can be traced to J. B. Yates, Sr., a school teacher who arrived from Tennessee in 1893. However, it was not until 1918 that a church was organized with ten charter 
members; services were held in a small church purchased from the Methodists on the corner of Sixth and "I" Streets, NW. In 1923, the membership moved into a newly built structure near the center of town on "B" street, and that continued to serve the needs of the congregation until the present church was built in 1967.

The presence of the Ardmore Adventist Hospital is certainly an important factor in the financial health and stability of the church. While a deceptively small percentage of the membership of the church works in the hospital (10 percent), several factors indicate that the impact of the hospital is greater than the percentage may first indicate. (1) Seven Adventist physicians live in the community, five of which have practices that are directly linked to the Adventist hospital. (2) Thirteen of the thirty-four pupils (38 percent) in BMJA are from families employed by the hospital. (3) Cash contributions from those employed by the hospital were in excess of $\$ 95,000$ in 1985 (35 percent of the total contributions collected by the church). (4) Hospital employees or spouses account for 41 percent of all church officers.

It is clear, then, that the hospital is an important factor in the health and vitality of the church. In fact, all of the institutions and services operated by the church or its members have their effect on the life of the church--perhaps to a lesser degree than the hospital, but nonetheless, significant. such 
factors as the organizational structure and the gathering and distribution of resources (i.e., church budget funds, volunteer labor) demonstrates a high degree of interdependence between these working groups.

Also, there is the ever present possibility of change. For instance, a falling hospital census due to a number of possible factors could have concomitant effects on church revenues perhaps necessitating a change in the nontuition policy of BMJA among other things. This kind of change could certainly spark conflict.

There is also the added factor of how power and authority are used. While sunbelt is analyzing the financial health of the smaller hospitals in its system, including Ardmore Adventist Hospital, the Ardmore Sanatarium and Hospital Corporation Board has the substantial financial reserves of Otey Johnson Trust. Thus far, a spirit of cooperation exists between these entities. However, certain philosophical differences may in the end drive them apart. While it is possible that these same philosophical differences could polarize the church, capable and compassionate leadership rightly trained could help maintain a climate of cooperation and communication that could forstall or even stop a division from forming in the church. of greater importance, however, is the fact that such leadership by modeling and teaching could lead members of the congregation into a spirit of openness and acceptance that would allow them 
to disagree over facts, means, goals, and even values without experiencing a disintegration in their interpersonal relationships.

Clearly, a number of elements in the Ardmore Adventist church make conflict a likely possibility. The changes in the hospital and the developing plans for a separate health center, the collapse of the black church and the movement of the remaining blacks to the white church, and the conflicting roles of the church board and school board over control of the school are all possible environments in which conflict could emerge.

\section{Description of the Participants}

A number of factors concerning the seminar participants are summarized in tables 4 and 5. These factors are compared and analyzed in four categories: general statistics, employment, church relationship, and seminar attendance.

\section{General statistics}

of the twenty-four people participating in the seminar, twelve were male and twelve were female. Male participation in the seminar was a significantly higher percentage than the percentage of males in the Ardmore congregation (38 percent).

Age was also significantly different. While only 28 percent of the congregation is under the age of forty, 41 percent of the participants were under forty. The 
TABLE 4

ANALYSIS OF THE SEMINAR PARTICIPANTS

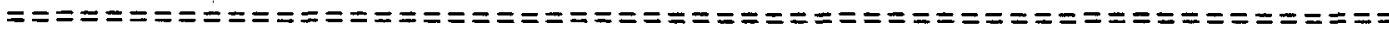

Part. Sex Spouse Age SDA ED in Profession Officer

Letter Yrs. Position

\begin{tabular}{|c|c|c|c|c|c|c|c|}
\hline A & M & $\mathrm{B}$ & 48 & $\mathrm{R}$ & 25 & Physician & $\begin{array}{l}\text { Elder, } \\
\text { Church Board }\end{array}$ \\
\hline B & $F$ & $A$ & 46 & $\mathrm{R}$ & 17 & Housewife & $\begin{array}{l}\text { Community } \\
\text { Service } \\
\text { Dir.' } \\
\text { Church Board }\end{array}$ \\
\hline C & $M$ & $\mathrm{D}$ & 65 & $\mathrm{R}$ & 18 & $\begin{array}{l}\text { Chaplain, } \\
\text { Pastor }\end{array}$ & \\
\hline $\mathrm{D}$ & $\mathrm{F}$ & C & 55 & $\mathrm{R}$ & 12 & $\begin{array}{l}\text { Dir. Day } \\
\text { Care }\end{array}$ & $\begin{array}{l}\text { SS Super. } \\
\text { Church Board }\end{array}$ \\
\hline$E$ & $\mathrm{~F}$ & & 69 & 49 & 13 & $\begin{array}{l}\text { LPN } \\
\text { (Retired) }\end{array}$ & $\begin{array}{l}\text { Johnson } \\
\text { Trust. }\end{array}$ \\
\hline $\mathrm{F}$ & $F$ & G & 41 & $\mathrm{R}$ & 16 & Medical & $\begin{array}{l}\text { Path. Dir. } \\
\text { Church Board }\end{array}$ \\
\hline G & $\mathrm{M}$ & $F$ & 41 & $\mathrm{R}$ & 16 & Account. & $\begin{array}{l}\text { Hosp. Adm. } \\
\text { School Board }\end{array}$ \\
\hline $\mathrm{H}$ & M & & 52 & $\mathrm{R}$ & 24 & Physician & $\begin{array}{l}\text { Elder, } \\
\text { Church Board, } \\
\text { School Board, } \\
\text { H\&S Board }\end{array}$ \\
\hline I & $F$ & & 35 & 2 & 12 & $\begin{array}{l}\text { Service } \\
\text { Rep. }\end{array}$ & \\
\hline $\mathrm{J}$ & $M$ & & 32 & 18 & 16 & Teacher & Deacon \\
\hline
\end{tabular}


TABLE 4--Continued

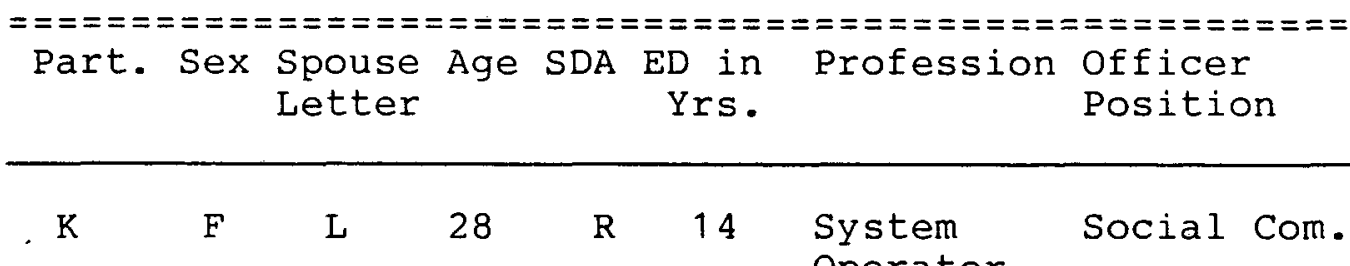
Operator

\begin{tabular}{|c|c|c|c|c|c|c|c|}
\hline L & $\mathbf{M}$ & $\mathrm{K}$ & 31 & $\mathbf{R}$ & 14 & Purchasing & Deacon \\
\hline M & $\mathrm{F}$ & & 33 & $\mathrm{R}$ & 18 & CRNA & $\begin{array}{l}\text { Deaconess, } \\
\text { Ss Sec. }\end{array}$ \\
\hline $\mathrm{N}$ & $\mathrm{M}$ & & 41 & $\mathrm{R}$ & 18 & CRNA & Deacon \\
\hline 0 & M & $\mathrm{P}$ & 32 & 11 & 14 & $\begin{array}{l}\text { Hwy } \\
\text { Inspect. }\end{array}$ & $\begin{array}{l}\text { Head Deacon, } \\
\text { Church Board }\end{array}$ \\
\hline $\mathrm{P}$ & $F$ & 0 & 31 & $\mathbf{R}$ & 16 & Chemist & Deaconess \\
\hline$Q$ & $\mathrm{~F}$ & & 32 & $\mathrm{R}$ & 12 & Sales & $\begin{array}{l}\text { SS Super. } \\
\text { Chruch Board }\end{array}$ \\
\hline $\mathrm{R}$ & $F$ & $\mathrm{~S}$ & 61 & 48 & 16 & Teacher & $\begin{array}{l}\text { Social Com. } \\
\text { Chair.' } \\
\text { Church Board }\end{array}$ \\
\hline$S$ & M & $\mathrm{R}$ & 76 & 44 & 17 & $\begin{array}{l}\text { Auditor } \\
\text { (Retired) }\end{array}$ & $\ldots$ \\
\hline $\mathrm{T}$ & M & & 62 & 10 & 17 & Physician & $\begin{array}{l}\text { Elder, } \\
\text { Church Board }\end{array}$ \\
\hline$U$ & $\mathrm{M}$ & $\mathrm{V}$ & 59 & 38 & 18 & Teacher & $\begin{array}{l}\text { Elder, } \\
\text { School Board, } \\
\text { Church Board }\end{array}$ \\
\hline $\mathrm{V}$ & $\mathrm{F}$ & $\mathrm{U}$ & 62 & $\mathrm{R}$ & 18 & $\begin{array}{l}\text { Dir. of } \\
\text { Nurses }\end{array}$ & $\begin{array}{l}\text { Com. Sec., } \\
\text { Church Board }\end{array}$ \\
\hline
\end{tabular}


TABLE 4--Continued

\begin{tabular}{|c|c|c|c|c|c|c|c|}
\hline Part. & Sex & $\begin{array}{l}\text { Spouse } \\
\text { Letter }\end{array}$ & Age & SDA & $\begin{array}{l}\text { Ed in } \\
\text { Yrs. }\end{array}$ & Profession & $\begin{array}{l}\text { Officer } \\
\text { Position }\end{array}$ \\
\hline W & $M$ & $\mathrm{x}$ & 30 & R & 16 & $\begin{array}{l}\text { Personnel } \\
\text { Director }\end{array}$ & $\begin{array}{l}\text { Deacon, } \\
\text { School Board }\end{array}$ \\
\hline$x$ & $F$ & W & 30 & 5 & 14 & $\begin{array}{l}\text { Personnel } \\
\text { Asst. }\end{array}$ & \\
\hline
\end{tabular}

average age of the seminar participant was forty-six.

Eight married couples were in attendance at the seminar. This translates to 66 percent of the participants. While 67 percent of the congregation is married, 28 percent of these have spouses that are not members of the church. Compared to the church, then, the seminar was composed of a higher percentage of married couples.

The educational level of the participants was high. Twenty-one of the participants have at least one year of college and sixteen (66 percent) have a college degree. This high level of education is not surprising in view of the professional orientation of the congregation.

\section{Employment}

Fourteen participants (58 percent) were employed in the Adventist hospital, a health-related field, or were spouses of such people (three physicians; two anesthetists; a hospital chaplain, an accountant, a personnel director, a personnel assistant, and a director 
of nursing; and four of their spouses). Of the three participants not currently employed, two were retired and one was a spouse of one of the physicians. Of the remainder, three were teachers, a chemist, a sales representative, a child day-care director, a phone company service representative, one in purchasing, and one systems operator.

It is interesting to note that none of the participants were employed in either blue collar or agricultural vocations. While the employment of a number of church members does fall into these categories, the seminar participants were from the service sector and many were professionals.

\section{Church Relationship}

All but four participants held church offices. Nine participants were church board members representing 50 percent of the board. Four of the six church elders were present, as was the head deacon, superintendent of the Sabbath School, social committee chairman, and school board chairman.

All three church-school teachers were present as was the director of Kinderland, the community services director, a member on the Otey Johnson Oil Producing Property Trust, as well as a member from the Ardmore Hospital and Sanatarium Corporation Board.

Fifteen participants (63 percent) were reared 
Adventists. ${ }^{1}$ Only three had been members of the church for ten years or less.

\section{Attendance}

The attendance record is recorded in table 5 .

TABLE 5

ATTENDANCE RECORD

\begin{tabular}{|c|c|c|c|c|c|c|c|c|c|}
\hline \multirow{2}{*}{$\begin{array}{l}\text { Participant } \\
\text { Letter }\end{array}$} & \multicolumn{8}{|c|}{ Session Number } & \multirow{2}{*}{ Test } \\
\hline & 1 & 2 & 3 & 4 & 5 & 6 & 7 & $\overline{8}$ & \\
\hline A & $x$ & $x$ & $\mathrm{x}$ & $\mathrm{X}$ & $x$ & $x$ & $x$ & $\mathrm{X}$ & $\mathrm{T}$ \\
\hline $\mathrm{B}$ & $\mathrm{X}$ & $\mathrm{X}$ & $\mathrm{x}$ & $\mathrm{X}$ & $x$ & $\mathrm{X}$ & $\mathrm{X}$ & $X$ & $\mathrm{~T}$ \\
\hline $\mathrm{C}$ & $\mathrm{X}$ & $\mathrm{X}$ & $\mathrm{X}$ & $\mathrm{X}$ & - & $\mathrm{x}$ & $x$ & $\mathrm{X}$ & $\mathrm{T}$ \\
\hline $\mathrm{D}$ & $\mathrm{X}$ & $\mathrm{X}$ & $\mathrm{x}$ & $\mathrm{X}$ & $\mathrm{x}$ & $\mathrm{X}$ & $\mathrm{X}$ & $\mathrm{X}$ & $\mathrm{T}$ \\
\hline$E$ & $\mathrm{X}$ & $\mathrm{X}$ & $x$ & $\mathrm{X}$ & $\mathrm{x}$ & $\mathrm{X}$ & $\mathrm{x}$ & $\mathrm{X}$ & $\mathrm{T}$ \\
\hline $\mathrm{F}$ & $\mathrm{X}$ & $\mathrm{X}$ & $\mathrm{x}$ & $\mathrm{X}$ & $\mathrm{x}$ & $\mathrm{x}$ & - & $\mathrm{X}$ & $\mathrm{T}$ \\
\hline $\mathrm{G}$ & $X$ & $\mathrm{X}$ & $\mathrm{X}$ & $X$ & $\mathrm{X}$ & $\mathrm{X}$ & - & $X$ & $\mathrm{~T}$ \\
\hline $\mathrm{H}$ & $\mathrm{X}$ & $\mathrm{X}$ & $\mathrm{X}$ & $X$ & $\mathrm{X}$ & $\mathrm{X}$ & - & $x$ & $\mathrm{~T}$ \\
\hline$I$ & $\mathrm{X}$ & $\mathrm{X}$ & $X$ & $X$ & $\mathrm{X}$ & $\mathrm{X}$ & X & $X$ & $\mathrm{~T}$ \\
\hline $\mathrm{J}$ & $\mathrm{X}$ & - & $\mathrm{X}$ & $X$ & $\mathrm{X}$ & $\mathrm{X}$ & $\mathrm{X}$ & - & $\mathrm{T}$ \\
\hline K & $\mathrm{X}$ & $\mathrm{X}$ & $\mathrm{X}$ & $X$ & $X$ & $X$ & $X$ & $X$ & $\mathrm{~T}$ \\
\hline $\mathrm{L}$ & $\mathrm{X}$ & $\mathrm{X}$ & $\mathrm{X}$ & $\mathrm{X}$ & $\mathrm{x}$ & $\mathrm{x}$ & $\mathrm{X}$ & - & $\mathrm{T}$ \\
\hline M & $\mathrm{X}$ & $\mathrm{X}$ & $\mathrm{X}$ & $\mathrm{X}$ & $\mathrm{X}$ & $X$ & $\mathrm{X}$ & - & $\mathrm{T}$ \\
\hline $\mathrm{N}$ & $X$ & $X$ & - & $\mathrm{X}$ & $\mathrm{X}$ & $x$ & $\mathrm{X}$ & $x$ & $\mathrm{~T}$ \\
\hline 0 & $X$ & $X$ & $\mathrm{X}$ & - & - & $X$ & $\mathrm{X}$ & $X$ & $\mathrm{~T}$ \\
\hline $\mathrm{P}$ & $\mathrm{X}$ & $\mathrm{X}$ & $\mathrm{X}$ & - & - & $\mathrm{X}$ & $x$ & $X$ & $\mathrm{~T}$ \\
\hline$Q$ & $\mathrm{X}$ & $\mathrm{X}$ & $X$ & $x$ & $\mathrm{X}$ & $X$ & $x$ & $\mathrm{X}$ & $\mathrm{T}$ \\
\hline $\mathrm{R}$ & $X$ & $X$ & $X$ & $X$ & $\mathrm{X}$ & $X$ & - & $x$ & $\mathrm{~T}$ \\
\hline$S$ & $\mathrm{X}$ & $X$ & $\mathrm{X}$ & $x$ & $\mathrm{X}$ & $x$ & - & $X$ & $\mathrm{~T}$ \\
\hline $\mathrm{T}$ & $X$ & $X$ & $\mathrm{X}$ & $\mathrm{x}$ & $\mathrm{X}$ & $X$ & $x$ & $x$ & $\mathrm{~T}$ \\
\hline $\mathrm{U}$ & $X$ & $X$ & $\mathrm{X}$ & $\mathrm{X}$ & $\mathrm{X}$ & $X$ & - & $X$ & $\mathrm{~T}$ \\
\hline V & $\mathrm{X}$ & $\mathrm{X}$ & $\mathrm{X}$ & $x$ & $\mathrm{X}$ & $X$ & - & $X$ & $\mathrm{~T}$ \\
\hline W & $x$ & $X$ & $x$ & $X$ & $X$ & - & - & - & - \\
\hline $\mathrm{X}$ & $\mathrm{X}$ & $X$ & $x$ & $x$ & $\mathrm{X}$ & $X$ & - & - & - \\
\hline
\end{tabular}

Attendance was 88 percent lout of a possible 192 person/sessions, twenty-two sessions were missed). A

${ }^{1}$ Note the SDA column in table 4. (SDA, seventhday Adventist; $R$, reared.) 
third of the participants missed no sessions at all and 79 percent missed one or less. The highest number of sessions missed by any student was three and only one student fell into that category. The rate of attendance during the first half of the program (sessions one through four) was 95 percent. During the second half, the attendance rate dropped to 81 percent. The session at. which the largest percentage of participants missed was session seven; nine participants (38 percent) were not at that session. Spring break certainly accounts for the high absentee rate for that session. In six of the eight sessions, three or fewer of the participants were absent.

\section{Conclusions}

While on the one hand it is true that those participating in the seminar are clearly not a representative group from the Admore church, it is equally clear that they represent a large portion of the leadership of the Ardmore church. Since informed leadership modeling conflict skills is a key element in conflict training in the church, it would appear that the high percentage of church officers participating in the seminar is crucial to the purpose of the program.

It would also be fair to assume that since participation in the seminar was voluntary, those who would attend would have a high degree of motivation not 
only to participate in the group activities but also to at tempt to apply the principles discussed in their life situation. The attendance statistics appear to bear this out. For instance, the attendance rate was 91 percent among the twenty-two who took the Conflict Attitude Test at the conclusion of the seminar.

It is also evident that all of the institutions and service organizations associated with the Ardmore church had participants in the seminar (ten from the Ardmore Adventist Hospital; one from the Ardmore Sanatarium and Hospital Corporation Board; one from the Otey Johnson oil Producing Property Trust; six from Beavers Memorial. Junior Academy--three teachers, four school board members; one from Kinderland House of Care; one from the Community Service Center; and nine from the church board). Personnel with conflict training could certainly have a positive effect not only within the organization in which they serve but their influence could also have an effect on the interrelationship of the various organizations listed above.

Description of the

Conflict Skills seminar

Following is (1) a statement of the objectives of the Conflict Skills Seminar, (2) a summary of each of the eight sessions that comprise the seminar, and (3) a brief analysis of the instructional rationale used in the development of the seminar. 
Seminar objectives

Introduction

The philosophy upon which the following instructional objectives are written is elaborated by Mager. His philosophy is that since all instruction is "effective to the de'gree that it succeeds in changing students in desired directions," instructional objectives should be written so as to "clearly specify the outcomes" that are desired in the student. ${ }^{1}$ He continues by suggesting several reasons why such thinking is beneficial. First, the writing of such statements is the first step that enables the teacher to select and arrange learning experiences for the student in accordance with principles of learning. ${ }^{2}$ second, such statements provide the basis for testing and evaluating. whether learning has taken place. ${ }^{3}$ Third, such statements provide students with the "means to organize their own efforts toward accomplishment of those objectives." 4

Statement of the instructional objectives

1. Be able to give an account of the origins of conflict from an Adventist perspective.

$$
\begin{aligned}
& { }^{1} \text { P. } 1 . \\
& { }^{2} \text { Ibid. } \\
& { }^{3} \text { P. } 6 . \\
& { }^{4} \text { Ibia. }
\end{aligned}
$$


2. Be able to identify the types and sources of conflict from case studies.

3. Be able to account for diversity in the church from a biblical perspective.

4. Be able to identify human differences in terms of the temperaments.

5. Be able to list five positive and five negative results that can develop because of the differences that naturally exist between individuals.

6. Be able to list five positive benefits that can result from tolerable levels of conflict.

7. Be able to demonstrate five approaches to the management of conflict in role-playing situations.

8. Be able to identify one's preferred conflict management style.

9. Be able to evaluate one's own preferred conflict management style in terms of its effectiveness in resolving conflict as well as its effectiveness in maintaining interpersonal relationships in a conflict.

10. Be able to indicate from scripture (Matt $5: 43-48$ ) the values that determine how a Christian views an antagonist.

11. Be able to demonstrate skill in drawing out and understanding another's viewpoint by the use of paraphrasing and perception checking in a role-playing situation. 
12. Be able to demonstrate power-building techniques in a role-playing situation.

13. Be able to demonstrate ability to help a role-playing antagonist to identify his/her feelings about a conflict issue.

14. Be able to demonstrate skill in absorbing emotionally charged language by the use of fogging and "I feel" statements in role-playing situations.

15. Be able to recount the sources of anger.

16. Be able to recite nine elements that seem to indicate open communication.

17. Be able to explain how anger relates to human temperaments.

18. Be able to recite the key elements of "Rational Emotive Training" and how it affects the way one views anger.

19. Be able to defend the concept of confrontation from scripture.

20. Be able to analyze one's conflicts based on the "Loyality Fighting Profile."

21. Be able to recite the biblical concept of reconciliation using at least two scriptures.

22. Be able to explain how reconciliation relates to conflict management.

23. Be able to demonstrate the role of body language in the process of communication using emblem gestures. 
24. Be able to show from scripture the function of leadership in the church as related to conflict.

25. Be able to recite the five functions of leadership as it relates to conflict.

26. Be able to demonstrate skill in the affirmation/assertive technique.

27. Be able to demonstrate the attending skills in a role-playing situation.

\section{Objective categories}

Table 6 demonstrates how these objectives are arranged in the Conflict skills seminar. From two to four objectives are met in each of the eight seminar sessions: two objectives are met in one session; three objectives are met in three sessions; and four objectives are met in four sessions.

Further, the objectives are sub-divided into three categories; biblical concepts, conflict theory, and communication skills. The four objectives met under the biblical concept category are the theology of conflict, diversity within the church, a Christian's attitude toward an "enemy," the biblical concept of confrontation, reconciliation, and the biblical concept of leadership.

The objectives under the category of conflict theory explore a number of concepts taken from current conflict literature that are consistent with the theology of conflict developed in session one. These objectives 
stress the application of knowledge in such areas as the identification of conflict types and sources, the identi-

TABLE 6

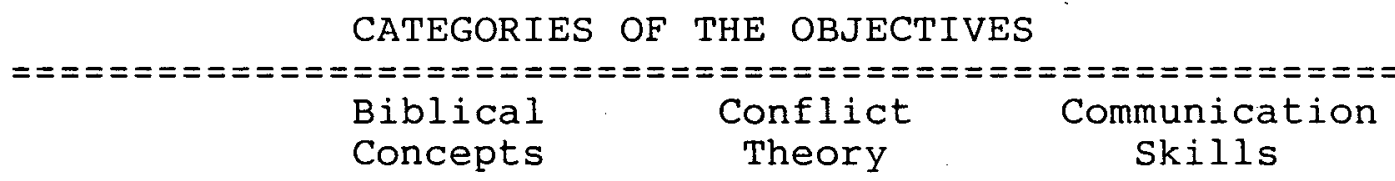

Session 1

Session 2

Session 3

Session 4

Session 5

Session 6

Session 7

Session 8
1

10

19

21

24
Conflict

fication of one's own conflict management style, the listing of positive benefits of conflict, the demonstration of power-building techniques, and so forth.

The objectives under the category of communication skills relate to both receiving and sending information. For instance, the process of receiving messages is covered by such listening skills as paraphrase, perception check, clarifying, and reflection; sending messages is covered by such skills as "I feel" statements, "fogging," the use of the "Fight Elements Profile," and body language. The distribution of the objectives over eight sessions assures that the sessions are not overloaded and that the material can be assimilated and put into practice and at a reasonable rate. 
Summary of Each Session

Following is a summary of the eight sessions of the Conflict Skills Seminar. 1

Session one--"Conflict:

Friend or Foe?"

Theme: Introduction to conflict

Purpose: (1) To help participants develop a theology of conflict that allows for the positive benefits that can come from conflict while at the same time not excusing the negative consequences of conflict. (2) To familiarize the seminar participants with conflict terms and definitions. (3) To inform the participants as to the three major ways in which conflict is experienced (intrapersonal, interpersonal, and substantive) with the primary consideration on substantive conflict. (4) To develop small-group dynamics through the use of ice-breakers.

Session two--"Pricked by Our Differences"

Theme: Diversity in the human family is often a source of conflict

Purpose: (1) To show that since diversity is an integral part of God's creation it should be expected that diversity is also evident in the church. (2) To demonstrate that conflict of ten develops as a result of

${ }^{1}$ See appendix 2 for the handouts used during the Conflict Skills Seminar. 
the differences that naturally exist between the perception and goals of one party and those of another party. (3) To encourage the seminar participants to explore their own unique temperament profile and, thereby, to increase their tolerance and appreciation for diverse temperaments of those around them.

\section{Session three--"You Can Change the Course of Conflict"}

Theme: The outcome of conflict can be influenced by the participants actions, reactions, and nonaction Purpose: (1) To show that conflict can lead to both positive and negative results. (2) To discuss the possible intervention strategies for dealing with conflict. (3) To test the participants for their preferred conflict management style. (4) To lead the participants in small-group practice of the conflict management styles for the purpose of increasing the number of skills available to them in conflict situations.

\section{Session four--"From Win-Lose} to Win-Win"

Theme: Power-building not only seems to reduce the intensity of conflict but also corresponds to Christian values

Purpose: (1) To show from scripture the Christian values that dictate how we are to look upon a fellow Christian with whom we disagree. (2) To 
demonstrate from conflict theory the possible goals or outcomes of conflict (e.g., lose-lose, lose-win, winlose, win-win). (3) To reveal the kinds of negative results that can come when one uses power to win a conflict. (4) To explain methods of power-building that have the effect of equalizing the power between two conflictive parties and that also seem to reduce the intensity of conflict and thus make problem solving easier. (5) To practice in role-playing situations the methods discussed above.

Session five--"Dealing with Emotion in Conflict"

Theme: Effective handing of conflict requires that attention be given to complicating emotions

Purpose: (1) To discuss the sources and implications of anger in conflict. (2) To discuss ways of coping with and reducing one's anger and hostility. To practice in small-group settings the processes of deflecting anger. (4) To discuss and practice in smallgroup settings the procedure of exploring not only the facts of the issue in contention but also the feelings that people have about it.

\section{Session six--"How to Fight Fair"}

Theme: Effective communication is fundamental to interpersonal maintenance.

Purpose: (1) To illustrate from scripture the 
process of loving confrontation. (2) To demonstrate the meaning of "loyality fighting." (3) To engage the participants in small-group role-playing "fights" scoring their "fairness" on the "Fight Elements Profile."1

\section{Session seven--"Reconciliation}

\section{--the Goal of Christian}

\section{Conflict"}

Theme: A Christian should give attention to both the preservation of interpersonal relationships and the issues of the conflict.

Purpose: (1) To demonstrate from scripture that the Christian is to engage in the work of reconciliation. (2) To show how reconciliation might relate to the process of conflict management. (3) To show strategies for guarding interpersonal relationships in conflictive situations. (4) To demonstrate the role that nonverbal communication plays in the total communication process. (5) To practice these skills while role playing in small groups.

Session eight--"The Christian Leader in Conflict Situations"

Theme: There are various processes available to the Christian leader that he can use in the management of conflict.

Purpose: (1) To demonstrate from scripture the

${ }^{1}$ George Bach, Intimate Enemy (New York: Avon Books, 1961), pp. 159-1 $\overline{67}$. 
role of leadership in the church as related to conflict. (2) To demonstrate from conflict theory the general approach a leader should take to prepare the church for conflict. (3) To demonstrate and practice in small groups the attending skills that increase the effectiveness of communication exchange.

\section{Analysis}

Since the goal of the seminar is help the participants develop positive and constructive conflict behavior, the seminar curriculum presents a blend of theory and information as well as the acquisition of certain skills. Information is seen as a catalyst that changes or shapes the attitude that in turn seems to play a role in shaping behavior. Add to this the fact that role playing also seems to be a vital factor in the process of integrating information into behavioral change and key elements are present upon which this seminar is built.

The kind of changes in attitude deemed important for behavioral change are: (1) attitudes toward conflict; (2) attitudes toward the differences that naturally exist between people; and (3) attitudes toward the antagonist in a conflict. Changes in the attitude along these lines increase the tolerance for conflict and encourages the kind of confidence necessary for one to participate constructively in a conflictive situation. 
The behavioral changes sought for are those that interfere with open and effective communication and thus prevent a solution from surfacing. Christian values are taken into consideration resulting in placing even greater value on the interpersonal relationships of those involved in a conflict.

\section{Schedule of Events}

The events that pertain to this section are those that either inform the congregation and/or church officers concerning the Conflict skills seminar or the events that surround the conducting of the seminar itself.

The congregation's first knowledge of this project came the Sabbath I assumed the pastoral responsibilites of the Ardmore Adventist church on August 3 , 1985. In his introduction of the new pastor to the congregation, Robert Rider, president of the oklahoma Conference of Seventh-day Adventists, mentioned that the new pastor was involved in the Doctor of Ministry program through Andrews University.

A week later, August 10, the Ardmore church elders met at my home for the purpose of getting acquainted and to discuss a number of items related to the church. One of the items discussed was the project that I wished to conduct in the church. The requirements of the Doctor of Ministry degree were discussed as well as the project 
outlined in this thesis. It was noted that there would be certain benefits to the congregation as they participated in the Conflict skills Seminar but that there would also be certain liabilities, especially as it related to the time necessary for the development of the seminar and the subsequent reporting on the seminar to fulfill the requirements of the degree.

A similar discussion took place with the Ardmore church board on October 21. The discussion concluded with a positive vote to allow the pastor to run the Conflict Skills Seminar during the winter of 1986 .

On February 1, 1986 the following announcement appeared in the Ardmore church bulletin: "A Conflict Skills Seminar taught by Pastor Johnson will begin this week. If you wish to join, meet in the pastor's study right after church to select the day for the meeting. The class meets weekly for eight weeks." Further information was given verbally during the announcement period between Sabbath School and the worship service. The points covered by the verbal announcement were as follows: (1) The seminar was for all who wished to develop skills that would help them preserve interpersonal relationships though engaged in a disagreement; (2) The seminar would be particularly helpful for church officers who must deal with conflict in a church setting; and (3) Participants in the seminar would be expected to make up sessions missed. Following the church service, 
twenty-two prospective participants met in the pastor's study and selected wednesdays, 6:00-7:30 p.m., for the sessions.

Another announcement appeared the following Sabbath: "The Conflict Skills Seminar continues this Wednesday, 6:00 p.m. in the fellowship room. If you would like to join, see Pastor Johnson today." As a result of this announcement, two more joined the seminar bringing the total number of participants to twenty-four. New participants along with those who missed sessions attended make-up classes which met at other than class time.

The first session of the seminar met on Wednesday evening, February 5, 1986. Sessions continued each Wednesday for the next five weeks. The remaining three sessions met Thursday evenings with the agreement of the participants due to scheduling difficulties.

The Conflict Attitude Test was administered to the seminar participants at the opening of the first session and again at the conclusion of the last session. The results of this test are discussed in chapter 4. The same test with a cover letter (see appendix 3, exhibit 2) was hand delivered by seven pastors who agreed to help with the task to forty prospective control group members in the state of Oklahoma. The test was handed to people who came to the February 8 church service on a random basis. Thirty-four of the original forty responded by 
returning their test in a self-addressed stamped envelope provided for that purpose. On March 6, a second copy of the test was sent to the control group with a cover letter (see appendix 3, exhibit 2). Of the thirty-four tests sent, twenty were returned. The results of this test are discussed in chapter 4 . 
CHAPTER FOUR

ANALYSIS OF THE PROJECT

This chapter analyzes the results of the conflict Skills seminar to ascertain whether the attitudes of the seminar participants toward conflict were significantly affected. This analysis is based on three factors: testing results; (2) the outlook of the participants; and (3) the conclusions of the pastor. Recommendations for a second implementation of this seminar conclude this chapter.

Testing Results

The testing instrument was the Conflict Attitude Test developed for the purpose of testing for changes in the attitudes of the seminar participants toward conflict and comparing the results with a control group. 1 Originally, this instrument was composed of thirty-five questions. During the final statistical analysis, however, only questions that exhibited a greater than .29 multiserial $R$ score were retained (see table 7). While

$1_{A}$ justification and description of the testing instrument is found in appendix 3. Basically, the Conflict Attitude Test was a quasi-experimental test using a nonequivalent control group design with a pretest and posttest. 
TABLE 7

TEST QUESTION ANALYSIS

\begin{tabular}{|c|c|c|c|}
\hline Question & $\begin{array}{l}\text { Proportional Score } \\
\text { Per Individual }\end{array}$ & $\begin{array}{l}\text { Point } \\
\text { Multiserial } R\end{array}$ & $\begin{array}{l}\text { Dis- } \\
\text { carded }\end{array}$ \\
\hline 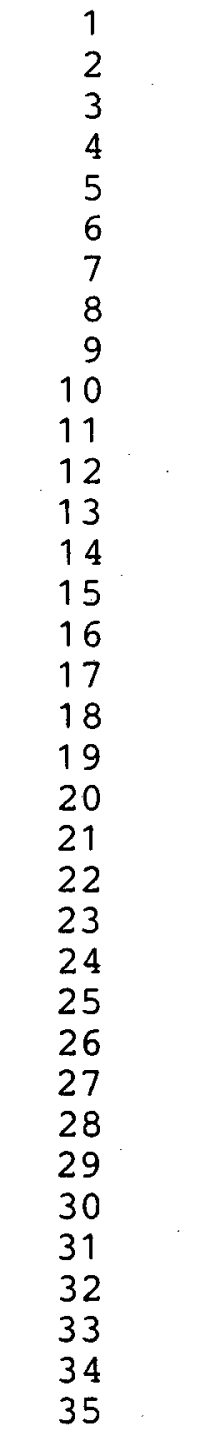 & $\begin{array}{l}.4683 \\
.5951 \\
.6146 \\
.8829 \\
.7122 \\
.6146 \\
.6146 \\
.7463 \\
.8780 \\
.7415 \\
.5415 \\
.7756 \\
.6780 \\
.7756 \\
.8000 \\
.8732 \\
.7707 \\
.7171 \\
.5122 \\
.8049 \\
.5902 \\
.4732 \\
.5561 \\
.5463 \\
.7371 \\
.9610 \\
.8195 \\
.6927 \\
.8049 \\
.5854 \\
.7268 \\
.8195 \\
.5512 \\
.8195 \\
.6098\end{array}$ & $\begin{array}{r}.1861 \\
.4512 \\
.2981 \\
.1025 \\
.5740 \\
.2774 \\
.5489 \\
.3735 \\
-.2471 \\
.6120 \\
.5381 \\
.3747 \\
.3771 \\
.5138 \\
.0961 \\
.7784 \\
.5504 \\
.4459 \\
. .0907 \\
.2093 \\
.3511 \\
.3031 \\
.5879 \\
.4158 \\
.3619 \\
.2822 \\
.4756 \\
.4413 \\
.6697 \\
.2236 \\
.1330 \\
. .0074 \\
.3941 \\
.4973 \\
.2033\end{array}$ & $\begin{array}{l}X \\
X \\
X \\
X\end{array}$ \\
\hline
\end{tabular}

this reduced the number of questions from thirty-five to twenty-three, it effectively raised the reliability coefficient alpha from .7986 to .8570 .

The test was applied to twenty-two participants in 
the treatment group and nineteen in the control group for a total of forty-one applications. Total possible points for any one score was 115 . The range was forty-eight to one hundred. The raw mean (see table 8 ) indicates a TABLE 8

ESTIMATE OF MEANS

\begin{tabular}{|c|c|c|}
\hline & Treatment group & Control group \\
\hline $\begin{array}{l}\text { Pretest } \\
\text { Posttest }\end{array}$ & $\begin{array}{l}77.3636 \\
89.5908\end{array}$ & $\begin{array}{l}80.2631 \\
78.5789\end{array}$ \\
\hline
\end{tabular}

shift of about twelve points $(+12.2272)$ upward from the pretest to the posttest in the treatment group while the control group dropped slightly $(-1.6842)$ between the two applications.

A more significant measurement, however, is the figures produced when the effect of the covariant is removed (see table 9). This produces an adjusted group

TABLE 9

ADJUSTED GROUP MEAN

\begin{tabular}{|c|c|c|c|}
\hline Group & Group mean & $\begin{array}{c}\text { Adjusted group } \\
\text { mean }\end{array}$ & $\mathrm{s}$ \\
\hline $\begin{array}{l}\text { Treatment } \\
\text { Control }\end{array}$ & $\begin{array}{l}89.59084 \\
78.57887\end{array}$ & $\begin{array}{l}90.44745 \\
77.58696\end{array}$ & $\begin{array}{l}1.65436 \\
1.78106\end{array}$ \\
\hline
\end{tabular}

mean that allows for a more accurate comparison of any changes that may have occurred between the two groups 
from the pretest to the posttest applications. The resulting figures indicate that the treatment group shifted 12.89 points in comparison with the control group. This shift indicates that the treatment group seems to have experienced a significant change in their attitude toward conflict between the two applications of the test. Furthermore, results also indicate that the attitude of the control group toward conflict remained nearly constant during the same period. It may be inferred that the shift experienced by the treatment group is a result of their exposure to the conflict skills seminar.

The internal integrity of the testing instrument is open to view by the analysis of covariance (ANOVA). This statistical procedure analyzes the difference between scores in a given sample (or group) in comparison with other scores in the same group. Likewise, it analyzes the difference between the means of the various samples (or groups) in comparison with other means. Table 10 contains the ANOVA data.

The mean square score is derived by dividing the sum of the squares by the degrees of freedom. The $F$ ratio is computed by dividing the between-group means square by the within-group means score. The resulting figure ( $F$ ratio) in this testing is 27.8033. The greater $F$ is than 1.0 , the higher the probability that the treatment group was affected by the implementation of the 
seminar. ${ }^{1}$ Also, adding significance to the validity of the $F$ ratio is the level of significance of the test which computed to be .00005 . It is generally felt that .05 is sufficiently conservative on a behavioral test to validate its findings. ${ }^{2}$

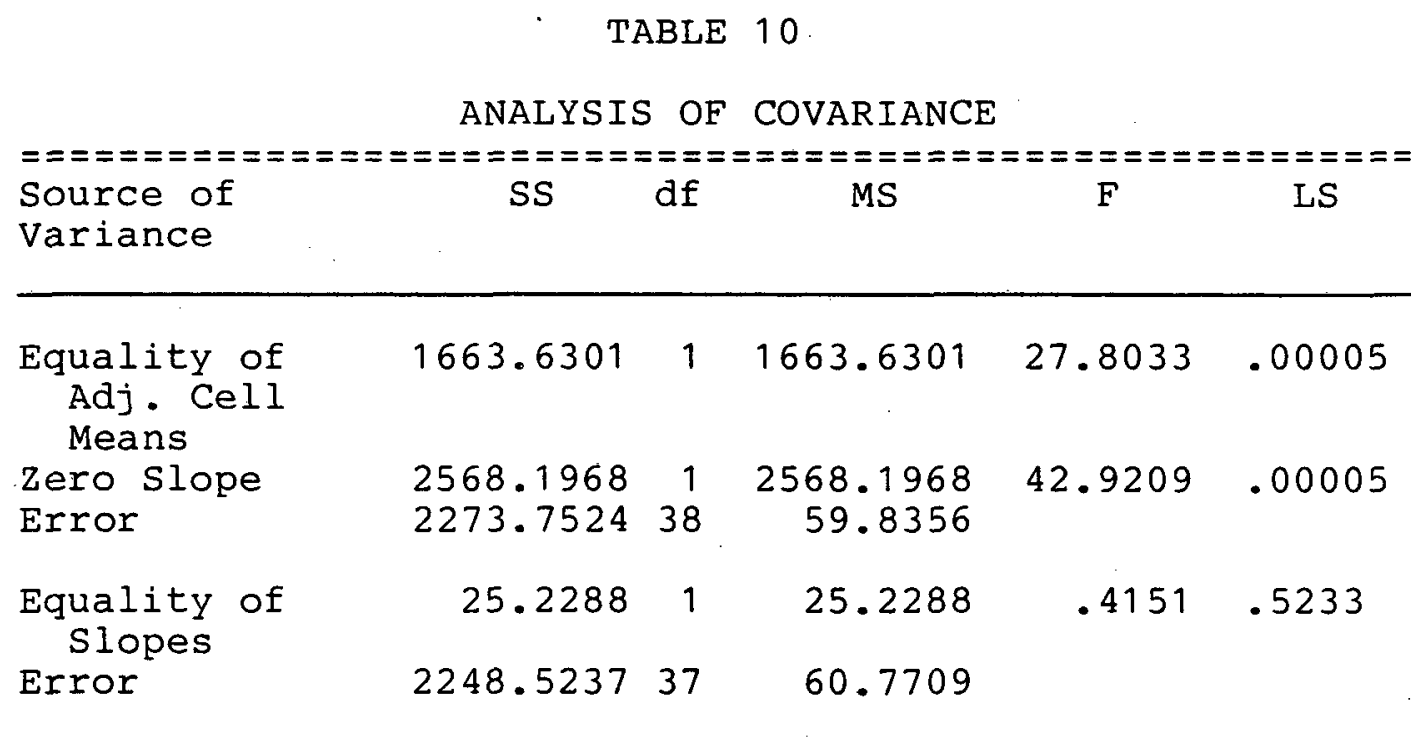

Key: $\quad$ SS $=$ sum of squares

$\mathrm{df}=$ degrees of freedom

MS = mean square

$\mathrm{F}=\mathrm{F}$ ratio

LS $=$ level of significance

One further statistical item also seems to validate the hypothesis of this paper. The $t$ value computed on thirty-eight degrees of freedom with a .00005 level of significance is -5.2729 . The critical t value

${ }^{1}$ David W. Martin, Doing Psychology Experiments, 2nd ed. (Monterey, Calif.: Brooks/Cole, 1985), p. 230 .

${ }^{2}$ Joan Welkowitz, Robert B. Ewen, and Jacob Cohen, Introductory Statistics for the Behavioral Sciences (New York: Academic Press, 1982), p. 131. 
for this test is 4.389 .1 The $t$ test determines whether the measurements of the pretest and posttest differ systematically. A $t$ value in absolute value (that is, ignoring the sign) ${ }^{2}$ that is larger than the critical $t$ is an additional reason for accepting the validity of the findings of the testing instrument.

\section{Outlook of the Participants}

Along with the Conflict Attitude Test, a feedback sheet was handed to the seminar participants at the conclusion of the last session (see appendix 4, exhibit 1). The directions on this sheet asked the participants to give their opinion on seven points: five dealing with key seminar elements (handouts, lectures, group activities, homework, and time allocation); one with how the seminar affected the participant's conflicts; and one asking suggestions regarding future conflict seminars.

No claim is made for the scientific accuracy of the feedback sheet or the responses. Instead, these responses are included for informative purposes with the understanding that they are simply subjective responses to selective questions.

${ }^{1}$ Robert Rosenthal and Ralph L. Rosnow, Essentials $\frac{\text { of }}{451}$.

${ }^{2}$ Welkowitz et al., p. 136 . 


\section{Handouts}

Generally, comments regarding the handouts were positive (see appendix 4, exhibit 2). Such comments as "helpful," "fine," "OK" characterize nearly a third of the responses. Four participants wrote that they intended to use the handouts as resource material by referring back to them in the future. Another respondent wrote that the handouts "helped gel some ideas that couldn't be covered in class."

The negative comments regarding the handouts centered in three areas. The first was the volume of material contained in the handouts. Four participants complained that there was too much material. Three of these added that there was too much material for the amount of time allocated to its study. The second area dealt with the pagination of the material. One respondent stated, "I was always confused about what is information only, homework, activities, etc." The third area dealt with the fact that a folder was provided in which the handouts were stored. One person suggested that a three ring notebook would have been more convenient.

Of the three areas of negative comment regarding the handouts, the amount of material in relationship to the amount of time available for the seminar seems to be significant. The fact that more material was presented in the handouts than could easily be covered in the 
lecture/discussion segments of the seminar seemed to be a source of concern and frustration to a significant number of participants.

\section{Lectures}

All of the participants' comments expressed positive elements regarding the lectures (see appendix 4 , exhibit 3 ). Perhaps the more helpful comments were regarding the interaction of the participants with the teacher during the lecture segments of the seminar. Two comments suggested satisfaction with the manner in which participants' questions and comments were handled. on the other hand, one comment suggested that more time was needed for questions.

Three comments also centered on the relationship of the lecture to the handouts. One participant wrote that the lectures gave "all material" attention. Another commented that although the lectures were "splendid," the handouts gave the opportunity to refresh the memory. A third commented that the lectures were helpful "in bringing together materials such as handouts, etc." These comments may indicate some confusion regarding the nature of the handout material and its relationship to the lectures. All lectures had handout material which was to be used by the participants for reference. Not all handout material, however, was included--or designed to be included--in the lectures. For instance, the group 
activities and the homework assignments were distinct from the lecture handouts.

\section{Group activities}

There was more divergent opinion expressed regarding group activities than in any other area (see appendix 4, exhibit 4). For instance, while some said that the group activities were "excellent and fun," "enjoyable," and "very good"; others said that they were "not particularly helpful," "mediocre," and "too limited." The positive comments cited three benefits of the group activities: (1) they gave opportunity to glean ideas from other participants; (2) they reenforced the points made during the lectures; and (3) they forced seminar students to participate. While it was true that the group activities forced participation, one student complained that though it was "always helpful," nonetheless it caused him/her to feel "awkward and uncomfortable" at times. It is clear, however, that the group was divided on this is sue because instead of less group activities, five participants either urged more group activities or for more time for what activities there were.

\section{Homework}

One participant suggested that the "information load (of the seminar) would be inadequate without... (the homework assignments)." However, the fact is 40 
percent of the participants either admitted they did not complete the homework assignments or questioned whether others completed them (see appendix 4, exhibit 5). It seems as though the major complaint of this group was not with the quality of the assignments but that they did not take the time to complete them. One participant suggested that time should be allotted prior, during, or after class for completion of these assignments.

\section{Time allocation}

The participants were asked to respond regarding their satisfaction with the amount of time allocated for the seminar (see appendix 4, exhibit 6). Fifty percent responded that the time was adequate. The remaining 50 percent suggested that either longer sessions or more sessions should be held to handle the amount of material presented. Noticeably lacking was any recommendation to reduce either the length or the number of sessions.

\section{Personal reflection}

The responses to the question, "How have the concepts covered in this seminar affected your conflicts?" seem to fall into two categories (see appendix 4, exhibit 7). First, the majority of respondents (68 percent) wrote statements that indicated that their attitudes toward conflict had changed. For example, representative comments include: "I look at conflict in a totally different way, I feel I can deal 
with it better and it's helped in my relationship with my wife"; and "I understand a little better how conflicts can be healthy." A correlative effect of a new attitude toward conflict is a new self-assurance as conflict is addressed. Representative comments include the two cited above and the following: "I feel that having a conflict can and should be constructive. And I feel more confident that I can engage in conflict with someone who has not had this seminar"; and "I feel more comfortable in dealing with hostility and anger with better understanding of (the) mechanics of dealing with these problems."

Second, respondents indicated that the seminar helped them form new attitudes toward others, especially as it relates to differences between people. As in the case above, these new attitudes are translated into a more confident way of relating to people. Representative comments are: "I believe for the first time in my life I now begin to understand many differences that exist between all of us"; and "(The seminar) helped me understand my spouse better and fellow workers better and how to relate to others and their feelings."

\section{Suggestions}

The final question on the feedback sheet asked, "What suggestions do you have for future conflict seminars?" Eight participants offered suggestions 
regarding the time/material ratio (see appendix 4, exhibit 8). By and large, these comments paralleled those offered in response to question five suggesting a more thorough coverage of the material and/or more time for group activities by increasing the length of the seminar.

Two participants suggested that something ought to be done about the domination of the question and discussion time by a few vocal participants. Another commented that private conversations ought to be discouraged during the seminar. These responses point out a dilemma inherent in the open nature of the seminar format. While the participants are encouraged to ask questions and offer comments at any time, the danger is that those who are more vocal do dominate while others who are less inclined to speak remain silent.

One participant suggested that the seminar ought to be offered on a regular basis and another suggested that a short follow-up course be added presumably for the benefit of those who took the regular course. Another suggested that the seminar could be reduced in length for the purpose of exposing more of the church membership to the seminar. Perhaps this person was reasoning that a shorter seminar would appeal to more people and thus participation would be increased.

Another suggestion was that Ellen G. White could be used to better advantage as an authoritative source of 
instruction, especially in the area of church conflict. Though her material was considered in the development of the theology of conflict (thus her influence underlies the entire conflict seminar), little effort was made to use her writings in a validative capacity.

A final comment worth noting was offered by an obviously troubled person who found the kind of help he/she needed in the seminar.

If it hadn't been for this seminar, I may have been a good suicide candidate. The conflicts I have (had) through the last five months have been so huge in my life (that) I don't think I could have made it. The help you have given and the guiding of the Holy spirit is really making a change in my outlook. Thank you from the bottom of my heart. Just pray for me.

\section{Conclusions of the Pastor}

The personal reflections contained in this section are divided into four categories: (1) mechanics and materials of the seminar; (2) quality and enthusiasm of the group; (3) application made of the material; and 4) general appraisal. This section is not intended to be evaluative in nature nor an analysis of either the seminar processes or results. Instead, it is intended to reflect the personal reaction, reflections and conclusions of myself as the pastor who conducted the seminar.

Mechanics and Materials of the Seminar

The seminar setting has positive elements that make it the format of choice for the application of the 
task outlined in this project. However, there are several weaknesses inherent in the seminar that are counterproductive. Interestingly, the weaknesses of the seminar are an outgrowth of the strengths that led to the use of the seminar format in the first place. First, while the seminar format encourages an atmosphere in which the participants can talk, it is not always possible to control either what it said or the length of time it takes for the participant to say it. Second, while it encourages those. who are vocal to be more vocal, it does not always lead the less vocal to speak. In fact, the domination of the time by the vocal may even discourage others from making a contribution. Third, there is a trade-off between group participation and time; the more participation there is by the group the less time there is for the teacher to disseminate information.

The materials that seemed to create the most interest were those that engage the participants in selfevaluation (Temperament Inventory instrument, the Conflict Management style Test, and the Anger Inventory). The fact that these were placed near the beginning of the seminar may have contributed to the high degree of interest and enthusiasm seen in the participants throughout the duration of the seminar. Another item that generated considerable discussion was the Rational Emotive Training (RET) material presented in session 
five. The fact that the concepts of RET run counter to established thinking probably accounts for the difficulty the participants experienced in understanding and applying the RET concepts. In a second application of the seminar, this material should be presented with authoritative references for support.

\section{Quality and Enthusiasm of the Group}

It was personally gratifying to have the quality of participants that attended the seminar. The high number of church officers (many of whom were also church board members), the high educational and professional level, and the mix from related Adventist institutions and groups served to make the seminar a success both in terms of the quality of interaction and in terms of the long-run results as the participants continue to work together in potentially conflictive situations. As leaders of the church, these people have the potential to shape not only the course of conflict but also the way in which people engage in conflict.

Also, this group exhibited enthusiasm for what they were learning. Their participation in the discussions and group activities, their high rate of attendance, and their readiness for introspection and self-evaluation all serve to indicate that they felt what they were learning was meaningful and valuable. 
Application Made of the Material

A number of conversations subsequent to the seminar have indicated that efforts have been made to apply the information provided in the seminar. For instance, one participant who avoided most conflict both at home and at work said that as a result of taking the seminar he now on occasion chooses to be more assertive by engaging in rather than avoiding conflict. Another participant who had the habit of alienating people because of his combative and arrogant demeanor has attempted to integrate communication skills that project him as open and caring. A final example includes a woman who found herself repeatedly hurt and angry as a result of her husband's remarks. She has now come to use certain skills that help her deal with her own emotions while engaged in conflict.

\section{General appraisal}

Certainly a pragmatic and perhaps a most meaningful appraisal of any program is whether it is was productive enough in its results to be used again. Pastors do not want for programs; there are many coming from church as well as nonchurch sources. However, since the church must be conscious of its stewardship responsibilities, the results of a program must offset its costs. There is also the additional factor that since the church must not be deterred from its primary 
task of mission, programs must be evaluated at least partially on the basis of whether they contribute to or hinder progress toward the mission of the church. It is my judgment that this seminar fulfills both criteria. The most valuable resource used in the conflict skills Seminar is time. It is time well spent, however, since it may save a great deal of time in the future--not to mention other church resources--that might otherwise be spent in fruitless conflict. Also, a church in dysfunctional conflict is not likely to make significant progress toward the fulfillment of its mission. Therefore, I not only plan to continue using the seminar in the churches I pastor but also I intend to make the material available in a form that other pastors can use in their churches.

\section{Recommendations for a second Implementation}

The recommendations that follow are based on the preceding analysis of the conflict skills seminar. For convenience, the recommendations are categorized under three headings paralleling the headings covered in this chapter: (1) Recommendations based on testing; (2) recommendations based on the participants' outlook; and (3) recommendations based on the pastor's reflection.

\section{Recommendations Based on Testing}

A first recommendation is that a second application of the seminar be made to ascertain whether 
the results achieved in the first application can be reduplicated. Very little can be inferred about the potential of the seminar for use in the church generally from one application. It is possible that such elements as the educational level of the seminar participants, the loyalty of the participants to the teacher and their desire to see him succeed, and the teacher's ownership of the program he developed has an unknown land perhaps substantial) influence on the success of the program.

A second recommendation is that this second application of the seminar be made by the pastor of the group selected. Since the project purports to be a program that pastors may be able to use with their congregations, it seems reasonable to assert that the success of the program is not fully tested until verified in actual field conditions.

A third recommendation is that the program be tested in multiple church environments. There are a number of factors that may make the Ardmore Adventist church out of the ordinary as compared to other Adventist churches (e.g., size, institutional setting, educational level). Most churches in the Adventist system have memberships of under 150 and lack a church-related institution for employment. The fact that the seminar seems effective in the Ardmore church does not mean that it will also be effective in the majority of these other situations. 
A fourth recommendation is that there should be long-term testing and evaluation to ascertain whether the results indicated by the initial testing are lasting changes. The question is whether a twelve-hour seminar over a period of eight weeks can result in lasting changes in people's conflict management style.

\section{Recommenciations Based on the Participants' Outlook}

A fifth recommendation is that the seminar be repaced so that the time/material ratio be more in keeping with the participants' ability to react and absorb the material presented. This could be achieved in one of three ways: (1) The amount of material could be reduced per each one and a half hour session by adding sessions; (2) the amount of material could remain the same per session by lengthening each session; and (3) the amount of material could be selectively reduced leaving the length of the sessions and the number of the sessions unchanged.

A sixth recommendation is that more time be allotted to group activities. While some of the participants admit that the practice sessions were at times awkward, it seems that permanent life-style changes can be achieved best as the students interact with the material presented. The amount of material presented combined with the time restraints sometimes resulted in rushed practice sessions. 
A seventh recommendation is that greater use of recognized authoritative sources be used. In the context of an Adventist group, this might be reflected in the use of Ellen G. White material on the subject of conflict. This is necessitated by the fact that the seminar presents a number of ideas and concepts that are new and, perhaps, even contrary to personally held views. The use of material that is viewed as authoritative by the seminar participants would be an aid in reshaping their attitudes as well as providing illustrative instances.

\section{Recommendations Based on the Pastor's Conclusions}

An eighth recommendation is that priority be given by conference and/or union administrators to the training of pastors in the area of conflict management. By and large, pastors are not well-equipped to deal with interpersonal conflict in the church. Generally, the style they employ for its management is Iimited to what they have found has worked in the past. Conflict training could open new methods of managing conflict by enabling pastors to select the most appropriate method of managing conflict based on the type of conflict they face.

A ninth recommendation is that a conflict training curriculum be published by the church for the purpose of conflict training in local congregations. The church has always been concerned with the education of its 
membership. 1 This education is not restricted just to matters of doctrine or faith. Instead, the church must ultimately concern itself with how its doctrines and faith are translated into relational matters. Education in the area of conflict training is certainly an acid test of the church's ability to translate its faith into terms that relate to what is potentially the best and worst in human relationships.

${ }^{1}$ Matt $28: 19-20$ 
A P P E N D I C E S 


\section{APPENDIX 1}

\section{INFORMATIONAL EXHIBITS}

1. Definitions of Conflict

2. Letter to the Church Officers 


\section{EXHIBIT 1}

\section{DEFINITIONS OF CONFLICT ${ }^{1}$}

I. Definitions favoring behavior.

". . conflict exists whenever incompatible activities occur."

"Conflict is the interaction of interdependent people who perceive incompatible goals and interference from each other in achieving those goals."

Conflict is a ". . protracted struggle, clash, fight, opposition between personalities, ideas, and interests."

"Social conflict results from the pursuit of what are perceived to be incompatible goals such that gains to one party occur at the expense of another."

"Conflict describes those experiences of individuals and groups trying to achieve goals which are either incompatible or appear to be so."

"Conflict is viewed as the active striving for one's own preferred outcome which, if attained, precludes the attainment by others of their own preferred outcome, thereby producing hostil ity."

II. Definitions favoring perception.

"Conflict occurs when two or more parties believe that what each wants is incompatible with what the other wants."

"Interpersonal conflict refers to the conflict which exists between individuals because of competing goals or differing viewpoints on how similar goals should be achieved."

Conflict is". . a situation in which two or more human beings desire goals which they perceive as being attainable by one or the other but not by both."

${ }^{1}$ See references respectively: King, "Three Cheers for Conflict!" p. 15; Joseph P. Folger and Marshall scott Poole, working Through Conflict (Glenview, Ill.: 
Scott, Foresman and Co., 1984), p. 4; Patterson, "Small Pump," p. 42; Weber, Management, p. 447; Rensis Likert and Jane Gibson Likert, New Ways of Managing Conflict (New York: MCGraw-Hill, 1976 ), p. 7 ; MCSwain, Con Ministryy, p. 26; Savage, "Getting In and Out of Conflict," p. 42; Richard and olsen, "Go to Your Corners," p. 7; Stagner, ed., The Dimensions of Human Conflict, p. 136, quoted by McSwain and Treadwell, Conflict Ministry, p. 25. 
828 LOCUST ST., N.W. $\quad-\quad$ ARDMORE, OKLAHOMA $73401 \quad \bullet \quad(405)$ 223-1975

\author{
January 29, 1986 \\ John Smith \\ Rt. 1, Box 75 \\ Ardmore, OK 73401 \\ Dear John,
}

The Conflict Skills Seminar that I have been working on in conjunction with my class work at Andrews University is now ready.

If you choose to be a part of this seminar, you will not only learn new and exciting information that will change your outlook toward conflict, but also you will learn and practice skills that can make your conflicts an opportunity for personal and interpersonal growth.

This seminar should be particularly helpful to you as a church officer. That is to say, because of your position in the church, you not only deal with conflictive and potential conflictive situations, but also you are bound by your faith to deal with conflict in a manner consistent with Christ's principles of love. This seminar will give you the knowledge and skills to deal with conflict in a Christian manner.

This seminar is composed of eight sessions with each session one and half hours in length.

If this seminar interests you, please meet with me for a few moments after church this Sabbath in the Pastor's Study for the purpose of selecting the day and time of the seminar meetings.

In Christ,

Jan G. Johnson, Pastor 


\section{APPENDIX 2}

CONFLICT SKILLS SEMINAR HANDOUTS

1. Session I

2. Session II

3. Session III

4. Session IV

5. Session V

6. Session VI

7. Session VII

8. Session VIII 
Conflict Skills Seminar

Session I

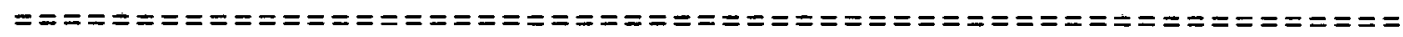

Handout $A$

THE CONFLICT SKILLS SEMINAR

Welcome to the "Conflict Skills Seminar."

During the next eight sessions, you will not only learn new and exciting information that will change your outlook toward conflict, but also you will learn and practice skills that can make your conflicts an opportunity for personal and interpersonal growth.

While you are waiting, please fill out Handout B, "Conflict Attitude Test."

This testing instrument will help your instructor evaluate the effectiveness of this seminar. Please be candid in your responses; there are no right or wrong answers--only your answers.

Remember, this instrument evaluates the course not the student.

After you have completed the "Conflict Attitude Test," return it to the receptionist. You will then be given Handout D, "What Is Conflict?"

This handout will form the basis of our first tenminute discussion. Read the questions carefully and mark your responses. 


\section{CONFLICIN ATITHUDE "THEST"}

\section{READ BEFORE YOU BEGIN}

The following questions are designed to examine how you perceive conflict.

Read each question thoughtfully, then circle the number that indicates the $\mathbb{D E G R \mathbb { E }}$ to which you $\mathbb{A G R E}$ or $\mathbb{D I S A G R \mathbb { E }}$.

It is important that you circle a number for EVERY question.

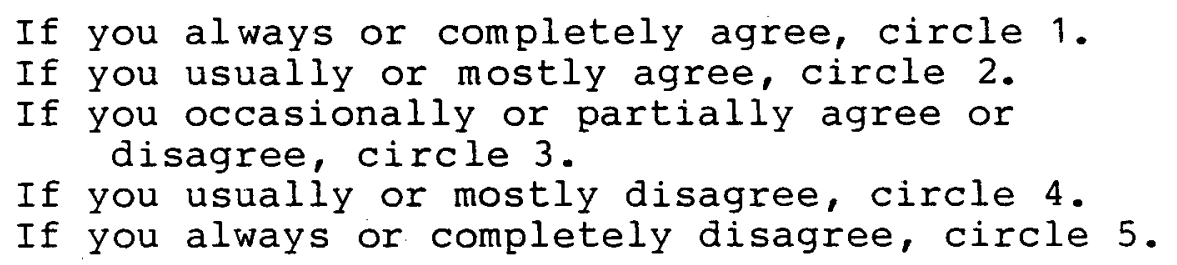

Please be honest and candid. There are No right or wrong answers.

QUESTION:

AGREE DISAGREE

1. Conflict occurs because of $\sin$ in $1.24 \quad 3 \quad 4 \quad 5$ the human heart.

2. I feel ill at ease when someone $\quad \begin{array}{llllll}1 & 2 & 3 & 4 & 5\end{array}$ disagrees with me in public.

3. I avoid people who have made me $\quad \begin{array}{llllll}1 & 2 & 3 & 4 & 5\end{array}$ angry.

4. Conflict arises because people $\quad \begin{array}{llllll} & 1 & 2 & 3 & 4 & \end{array}$ view situations differently.

5. It is best not to bring sensitive $\begin{array}{llllll}1 & 2 & 3 & 4 & 5\end{array}$ issues to the surface because it only seems to increase conflict.

6. When in a conflict, I feel compelled to win.

7. It is best to avoid a situation $\quad \begin{array}{llllll}1 & 2 & 3 & 4 & 5\end{array}$ that may result in conflict.

8. It is possible for conflict to $\quad \begin{array}{llllll}1 & 2 & 3 & 4 & 5\end{array}$ have a positive effect on church life. 
Conflict Skills Seminar

Session I

= = = = = = = = = = = = = = = = = = = = = = = = = = = = = = = = = = = = = = = = = = = = = =

Page 2

Handout $B$

QUESTION :

9. The church should allow people to express their differing opinions.

10. Conflict is out of place in the church.

11. I worry that if I get angry in a conflict I may say things that I'll regret.

12. I get irritated with people who express ideas that conflict with mine.

13. Conflict closes the lines of communication.

14. To love others is to avoid conflict with them.

15. If a person is agitated on some $\quad \begin{array}{llllll}1 & 2 & 3 & 4 & 5\end{array}$ issue in the church, he should be allowed to express his opinion.

16. Conflict is the opposite of caring for people.

AGREE DISAGREE

$\begin{array}{lllll}1 & 2 & 3 & 4 & 5\end{array}$

$\begin{array}{lllll}1 & 2 & 3 & 4 & 5 \\ 1 & 2 & 3 & 4 & 5\end{array}$

$\begin{array}{lllll}1 & 2 & 3 & 4 & 5\end{array}$

If church members were converted, $\begin{array}{llllll}1 & 2 & 3 & 4 & 5\end{array}$

they would not be in conflict.

18. The less said when people are $\quad \begin{array}{lllllll}1 & 2 & 3 & 4 & 5\end{array}$ in disagreement the better.

19. Conflict occurs most often in congregations in which there is

a deep commitment to the church.

20. An open expression of differences $\begin{array}{lllllll}1 & 2 & 3 & 4 & 5\end{array}$ of opinion is good for the church.

21. If there is conflict in the church, the pastor should preach on the subject of unity.

22. I feel frustrated and upset when $\begin{array}{lllllll}1 & 2 & 3 & 4 & 5\end{array}$ someone gets angry with me. 
Conflict Skills Seminar

Session $I$

= = = = = = = = = = = = = = = = = = = = = = = = = = = = = = = = = = = = = = = = = = = = = = =

Page 3

Handout $B$

QUESTION :

23. The church functions best when

AGREE DISAGREE conflict is not present.

24. I feel confident in dealing with $1 \quad 2 \quad \begin{array}{lllll}3 & 4 & 5\end{array}$ people who are angry with me.

25. If there is conflict over an issue in a business meeting, it is best to limit discussion and vote before people lose control of their tempers.

26. In an argument, it may be to my advantage to point out my opponent's spiritual weaknesses.

27. Conflict is normal and unavoidable $\begin{array}{llllll}1 & 2 & 3 & 4 & 5\end{array}$ whenever people come together in organizations (including the church).

28. In a conflict, it is best to disregard people's personal feelings about the issue and stick to the facts of the issue.

29. Conflict in the church should be $\begin{array}{llllll}1 & 2 & 3 & 4 & 5\end{array}$ suppressed.

30. Majority vote is a fair and appropriate way of settling $\begin{array}{lllll}1 & 2 & 3 & 4 & 5\end{array}$ conflict.

31. One reason there is so much conflict is because people hold

$\begin{array}{lllll}1 & 2 & 3 & 4 & 5\end{array}$
such unusual ideas.

32. It is not' possible for an organization to go through change without also experiencing conflict.

33. A Christian leader may find it necessary to escalate conflict. 
Conflict Skills Seminar

Session I $=====$
Page 4 Handout $B$

QUESTION

34. In a conflict, I might have to AGREE DISAGREE reveal some unrelated but embarrassing information about the other person if it would help truth prevail.

35. Conflict leads to positive $\begin{array}{lllll}1 & 2 & 3 & 4 & 5\end{array}$ results.

36. Date of your birth.

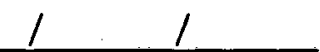

37. Number of years of education. 
= = = = = = = = = = = = = = = = = = = = = = = = = = = = = = = = = = = = = = = = = = = = = = Page 1

Handout $\mathrm{C}$

"CONFLICT: FRIEND OR FOE?"

OUTLINE

I. Pre-session

A. Register the seminar participants

B. Give the participants the following handouts titled:

Handout A--"The Conflict Skills Seminar"

Handout B--"Conflict Attitude Test"

Handout C--"Outline"

Handout D--"What Is Conflict?"

II. What is conflict? (10 minutes)

A discussion centering on the participants' ideas about conflict aided. by Handout D, "What is Conflict?"

III. Analysis of conflict types and sources (20 minutes) Handout E--"Definitions of Conflict"

Handout F--"Analysis of the Types of Conflict"

Handout G--"Definitions of the Four Types of Conflict"

An introduction to conflict and a discussion of the various types of conflict.

IV. Practice session--identification of the sources of conflict $(20$ minutes $)$

Handout $\mathrm{H}--$ "Case Study 1 "

Small group practice of the concepts learned.

V. Theology of conflict (20 minutes)

Handout I--"Theology of Conflict"

A lecture about the origin and outcome of conflict from a biblical perspective.

VI. Justification of the seminar (10 minutes)

Handout J--"Course Objectives"

Handout K--"Course Outline"

A clarification of the objectives of the seminar so as to shape expectations and formulate goals in the minds of the participants. 
Conflict Skills Seminar

Session I

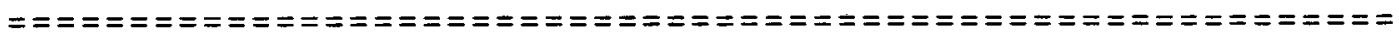

Page 2

Handout $\mathrm{C}$

VII. Homework assignment ( 5 minutes)

Handout L--"Case Study 2"

An at home practice assignment featuring the identification of the sources and types of conflict. This assignment will form the basis of discussion at the beginning of the next session. 
I. Circle those with which you agree.
A. Conflict occurs because we care.
B. Conflict is a consequence of sin.
C. Conflict signifies vitality and life.
D. Conflict increases communication and under- standing.
E. Conflict is Satan's way of diverting us from our mission.
F. Conflict is neither good nor bad; it is simply inevitable.
G. Conflict results in hurt feelings and strained relationships.
H. Conflict is best avoided.
I. Conflict is an asset to the work of Christ.

II. Circle the definition of conflict with which you most closely agree.

A. Conflict occurs when one personality clashes with another.

B. Conflict results from the pursuit of incompatible goals so that gains to one party occur at the expense of another.

C. Conflict occurs when two or more parties believe that what each wants is incompatible with what the other wants.

II. Circle one response to the following questions.

A. In this church we have

1. open conflicts

2. mainly submerged conflict

3. almost no conflict

B. Our conflicts are primarily over

1. personalities

2. facts

3. means--how something is to be done

4. goals--what is to be done

5. values 
Conflict Skills Seminar

Session I

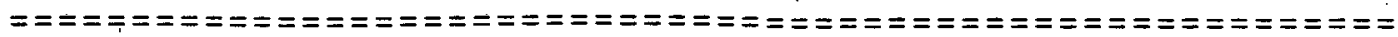

\section{DEFINITIONS OF CONFLICT}

Handout $\mathrm{E}$

Mark whether the following definitions favor behavior (actions signaling the presence of conflict) or thinking (perceptions that form the basis of conflict).

Behavior Thinking

". . conflict exists whenever incompatible activities occur."

"Conflict occurs when two or more parties believe that what each wants is incompatible with what the other wants."

"Conflict is the interaction of interdependent people who perceive incompatible goals and interference from each other in achieving those goals."

Conflict is a ". . protracted struggle, clash, fight, opposition between personalities, ideas, and interests."

"Interpersonal conflict refers to the conflict which exists between individuals because of competing goals or differing viewpoints on how similar goals should be achieved."

"Social conflict results from the pursuit of what are perceived to be incompatible goals such that gains to one party occur at the expense of another."

"Conflict is viewed as the active striving for one's own preferred outcome which, if attained, precludes the attainment by others of their own preferred outcome, thereby producing hostility."

Conflict is ". . a situation in which two or more human beings desire goals which they perceive as being attainable by one or the other but not by both." 
Conflict Skilis Seminar Session. I

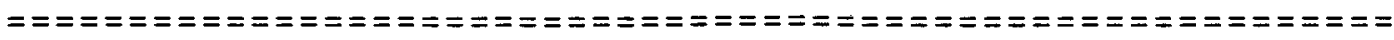
Handout $F$

\section{ANALYSIS OF THE TYPES OF CONFLICTS}

There are three major ways in which conflict is experienced.

1. Intrapersonal Conflict

2. Interpersonal Conflict

3. Substantive Conflict

A. Facts

B. Means/methods

C. Goals/ends

D. Values 
Conflict Skills Seminar

Session I

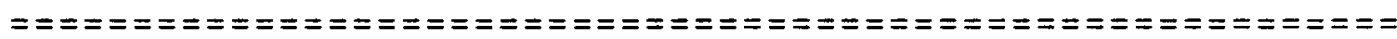
Page 1

Handout $G$

DEFINITIONS OF THE FOUR TYPES OF CONFLICT

Substantive conflict can be divided into one of four types. Master these types and practice analyzing your conflicts.

\section{FACTS}

Conflict may develop over the facts of a situation. For example, some may say that the church budget offering has dropped of during the last year, whereas others may say that it is increasing. This conflict can be settled by checking the treasurer's reports.

\section{MEANS/METHODS}

Conflict can also develop over the means or methods for achieving a solution to a problem. We may agree that giving to the church budget has dropped of during the last year, but we may disagree as to what ought to be done about it. one person believes that a strong preaching series on the subject of stewardship would correct the problem while another feels that "strong preaching" has already alienated members and is part of the problem. Or there may be agreement that the church should evangelize the community, but there is contention as to what program (i.e., method) of evangelism should be used.

A couple may agree that they need to reduce their spending but one wants to cut down on the clothing budget while the other wants to cut down on entertainment.

\section{GOALS/ENDS}

A more difficult conflict to resolve is disagreement over goals or the kinds of results desired. This is illustrated by a contest over the purpose of a church school. Is it an evangelistic agency that should reach out to community children? Or is it a sheltered community--a place away from the "world"--for "worthy" Adventist children?

This type of conflict is often found at the base of wage disputes. An employer's goal is to maintain the institution's profitability while the employee's goal is to receive a larger paycheck. 
Both would have methods of achieving his goal. An employee may strike, engage in a work slow down, or pilfer company property. On the other hand, an employer would use such methods as he deemed necessary to protect the interests of the company--use "scabs", use threat of job loss, or use incentives.

Goals are philosophical in nature whereas means/methods are concrete. Questions such as the following indicate goals: What is the committee's purpose? What is the direction we need to take in this department? What is the aim of our company? What is the mission of our church? What kind of adults do we want our children to become?

IV. VALUES

Values differ from goals in that values form the foundation upon which goals are built. Goals determine the direction that the organization will take but values determine which goals will be chosen. All social systems have a body of common values, beliefs, and sentiments. These are the criteria by which goals and means are selected.

A theological or doctrinal dispute is an obvious conflict over values. Other conflicts involving values may not be so clear. For example, a conflict involving such issues as the wedding ring, serving meat at fellowship meals, or theater attendance may seem to be a conflict over methods. However, the real issue usually involves one's values and belief structure more directly than the usual conflict over means/methods. Therefore, the approach one would use to deal with such conflict would necessarily be different than the approach used to deal with a conflict over means/methods.

Other examples of conflict over values include a Sabbath work problem, a Catholic 'woman facing pressure from a noncatholic spouse to use birth control methods, an Adventist facing pressure from a non Adventist spouse to engage in what he/she believes to be Sabbath-breaking activities. 
= = = = = = = = = = = = = = = = = = = = = = = = = = = = = = = = = = = = = = = = = = = = = = =

Page 1

Handout $\mathrm{H}$

\section{CASE STUDY 1}

Case 1:

Scene: A married couple discussing the need for a new car.

He (angry): "I've about had it with that car! Look at this repair bill. Do you realize that in the last four months we have spent nearly $\$ 300$ just to keep that old junk heap on the road?"

She (soothingly): "It does seem like quite a bit but at least its paid off so we aren't making payments. I guess we can live with some repair bills."

He (not too soothed): "Oh, Yes?! You never know what's going to happen next to the car. A wheel bearing last month, an alternator this month, the engine next month. we can't trust that car on our vacation."

She (interíuts): "At least we can afford a vacation. If we buy a new car, we may as well kiss a vacation goodbye."

He (aryly): "Oh, we'll get a vacation alright. We may have to spend it here at home but we'll have one. We're also going to get a new car--I've made my decision."

She (obviously angry): "Great! Another home vacation just because you have to have a new car."

She walks out of the room letting her words trail after her: "I hope you enjoy your vacation; I'll have to wait another year for mine." 
Conflict Skills Seminar

Session I

Page 2

Handout $\mathrm{H}$

Case 2 :

Scene: The Sabbath School Council discussing whether to have a department for academy-aged youth.

First person: "It is obvious that our church offers a Sabbath School program for every age group but the youth. They are left to themselves! I suppose that some are attending the adult program while others are attending an early teen department. But I believe that they need their own program."

Second person: "I agree with you. If there is a need, we must fill it."

Third person: "I agree as well. However, do we have enough youth to justify a new department?"

First person: "I found about a dozen on the church membership records, but the number is not the issue as I see it. We need to offer a program even if only one or two attend."

Third person: "One or two are probably about all we have that attend regularly. Most of the others attend academy or attend church infrequently."

Second person: "I sympathize with the idea of offering a program for only one or two. However, I think that it would be a foolish waste of resources to do so. It would be much better to incorporate our youth into an existing. program." 
Conflict Skills Seminar Session $I$

= = = = = = = = = = = = = = = = = Page 1

$=======$

THEOLOGY OF CONFLICT

I. Three Views of the Origin of Conflict

A. Conflict originated with $\sin$

B. Conflict results from human limitations

C. Conflict results from dualism

II. Toward a Christian View of Conflict

A. Adventist Godward approach to theology 


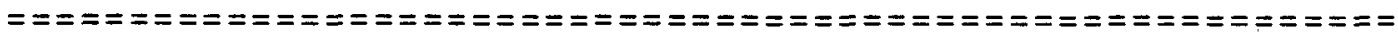
Page 2

B. Potential for conflict resident in creation

C. Conflict-- a conceptual model

THEOLOGICAL CONCEPTUAL MODEL OF CONFLICT

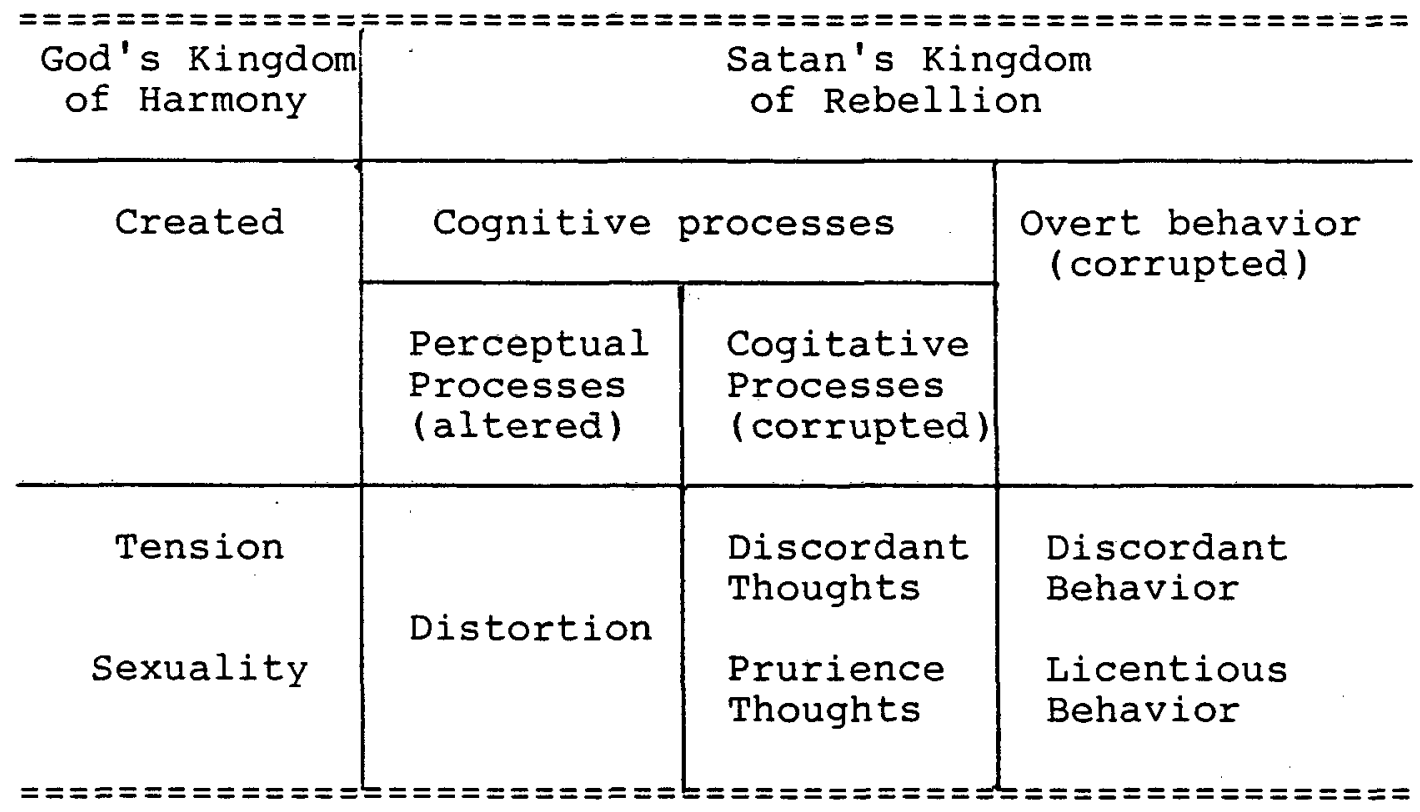




\section{COURSE OBJECTIVES}

1. Be able to give an account of the origins of conflict from a Seventh-day Adventist perspective.

2. Be able to identify the types and the sources of conflict from case studies.

3. Be able to account for diversity in the church from a biblical perspective.

4. Be able to identify human differences in terms of the temperaments.

5. Be able to 1 ist five positive and five negative results that can develop because of the differences that naturally exist between individuals.

6. Be able to list five positive benefits that can result from tolerable levels of conflict.

7. Be able to demonstrate five approaches to the management of conflict in role-playing situations.

8. Be able to identify one's preferred conflict management style.

9. Be able to evaluate one's preferred conflict management style in terms of its effectiveness in resolving conflict as well as its effectiveness in maintaining interpersonal relationships in a conflict.

10. Be able to indicate from scripture (Matt 5:43-48) the values that determine how a Christian views an antagonist.

11. Be able to demonstrate skill in drawing out and understanding another's viewpoint by the use of paraphrasing and perception checking in a roleplaying situation.

12. Be able to demonstrate power-building techniques in a role-playing situation.

13. Be able to demonstrate ability to help a roleplaying antagonist to identify his/her feelings about a conflict issue. 
14. Be able to demonstrate skill in absorbing emotionally charged language by the use of fogging and "I feel" statements in role-playing situations.

15. Be able to recount the sources of anger.

16. Be able to recite nine elements that seem to indicate open communication.

17. Be able to explain how anger relates to human temperaments.

18. Be able to recite the key elements of "Rational Emotive Training" and how it affects the way one views anger.

19. Be able to defend the concept of confrontation from scripture.

20. Be able to analyze one's conflicts based on the "Loyality Fighting Profile."

21. Be able to recite the biblical concept of reconciliation using at least two scriptures.

22. Be able to explain how reconciliation relates to conflict management.

23. Be able to demonstrate the role of body language in the process of communication using emblem gestures.

24. Be able to show from scripture the function of leadership in the church as related to conflict.

25. Be able to recite the five functions of leadership as it relates to conflict described by speed Leas.

26. Be able to demonstrate skill in the affirmation/assertive technique described by David Augsburger.

27. Be able to demonstrate the attending skills in a role-playing situation. 


\title{
COURSE OUTLINE
}

\author{
Session I \\ "Conflict: Friend or Foe?"
}

An introduction to conflict centering on the types and sources of conflict.

\author{
Session II \\ "Pricked by Our Differences"
}

A proper understanding of the diversity within the human family is an essential element in Christian conflict theory.

\section{Session III}

"You Can Change the Course of Conflict"

Conflict has the potential of positive and/or negative results, and further, its outcome can be influenced by the participants' actions, reactions, and even nonaction.

\section{Session IV \\ "From Win-Lose to Win-Win"}

Power-building not only seems to correspond to Christian values but also seems to reduce the intensity of conflict as a solution is sought.

\section{Session $V$ \\ "Dealing with Emotion in Conflict"}

Dealing effectively with conflict from a Christian perspective requires attention given to complicating emotions.

$$
\begin{aligned}
& \text { Session VI } \\
& \text { "How to Fight Fair" }
\end{aligned}
$$

Fighting fair involves communicating clearly to the right person one's feelings and beliefs about the issues that are in contention. 
Conflict Skills Seminar

Session $I$

= = = = = = = = = = = = = = = = = = = = = = = = = = = = = = = = = = = = = = Page 2

Handout $\mathrm{K}$

\section{Session VII}

"Reconciliation--the Goal in Christian Conflict"

A Christian view of conflict includes a concern for the healing of interpersonal relationships as well as resolving the issues of the conflict.

Session VIII

"The Christian Leader in Conflict Situations"

There are various processes available to a Christian leader that can be used in the management of conflict. 
Conflict Skills Seminar

Session I

$====$
Page 1

Handout $\mathrm{L}$

\section{CASE STUDY 2}

Directions: Read through this case study noting the types of conflict manifested. Write in the right margin whether the conflict is over facts, means, goals, or values.

"I don't see how we can go ahead with our plans for an evangelistic meeting at this time." The Pastor's words were still ringing in the ears of the personal ministries director as he walked across the parking lot toward his car. The church board seemed so supportive of a fall campaign two months ago. Considerable work had been done since then including setting up a budget, securing an evangelist, engaging conference cooperation, and developing a visitation program for the church. Now all that work was down the drain not to mention the embarrassment of having to cancel the evangelist. As he drove home, the director tried to reconstruct the events that led up to the proposal's defeat.

During the board meeting two months ago, the director presented what he thought was a well-reasoned statement on the importance of reaching the community for Christ. Taking the silence that followed as agreement, he then proceeded to present his evangelistic plans which included securing the services of a well-known evangelist at considerable expense. This expense, he noted, was to be shared by the church and the conference. He also mentioned that there was the likelihood of a sizable anonymous gift. The treasurer ask for a specific dollar figure that would represent the obligation to be assumed by the church but the director could not be more specific. The director assured him, however, that he would have that information at the next board. An elder questioned the advisability of holding a series of evangelistic meetings during a time when the church was in an obvious spiritual decline. The pastor suggested that it is just such a time when an evangelistic meeting is most needed. The elder responded dryly, "I thought that evangelistic meetings are to convert the community not the church."

At the next board, the evangelistic budget continued to be discussed. "I don't care how you cut it," the treasurer concluded, "the church just can't afford it." Several board members seemed to agree with treasurer. "We are responsible to the congregation to balance the books. Obviously, we cannot pay for an evangelist on what we are currently receiving through offerings," was 
Conflict Skills Seminar

Session I

Page 2

Handout $\mathrm{L}$

one comment. The director countered by paraphrasing scripture, "we can do all things through Christ who strengthens us." The director overheard an elder mumble that that was supposing members were allowing christ to strengthen them. The vote was 8 to 5 to continue planning for the series.

During tonight's board, the evangelistic budget came up during the treasurer's report. The report indicated that the church budget had fallen even further into the red. The treasurer said that he suspected that some of the members were withholding their church budget offerings. The pastor seemed reluctant to accept that as a fact. "That may not be true," he said, "people may not give offerings for a month or two for any one of a number of reasons." That's when one of the elders pushed back his chair, stood, leaned over the table resting on his fists, and said, "It's that stupid campaign. You can't expect people to continue giving offerings when we spend money foolishly."

"We don't know if that's the reason some aren't giving," the pastor countered.

Speaking louder than necessary, the elder replied, "That's the reason I'm not giving! And I know that I'm not the only one. You're talking about holding evangelistic meetings when what we really need is a revival."

The board sat in stunned silence. Then the pastor said with an edge in his voice, "There are a lot of things we need! But the gospel commands us to make disciples. I don't believe that we have a choice in this matter."

The elder strengthened to his full height, folded his arms and said, "God didn't send the disciples into the world until they experienced Pentecost. I don't see anything like pentecost here. You can hold your evangelistic meeting if you want, but you will do it by yourself. I've talked to a lot of people about this thing and they agree with me."

The pastor and director were silent for some time while the discussion continued around them. It was clear that support for the series had eroded. Finally, the pastor spoke, "I don't see how we can go ahead with our plans for an evangelistic meeting at this time." 
Conflict Skills Seminar

Session II

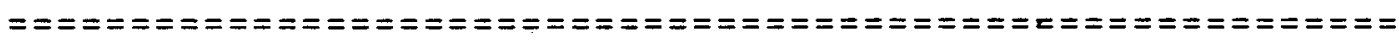
Page 1

Handout $A$

"PRICKED BY OUR DIFFERENCES"

OUTLINE

I. Pre-session

Handout A--"Outline"

II. Theology of conflict (20 minutes)

Handout B--"Theological Steps in Conflict"

Conclusion of the lecture about the origin and outcome of conflict from a biblical perspective.

III. Practice session--identification of the types of conflict (10 minutes)

Small group practice of concepts learned using Handout L ("Case Study 2") from Session I.

IV. Temperament Analysis Test (15 minutes)

Handout C--"Temperament Inventory"

A psychological instrument dividing the human temperament into four categories.

V. Group inductive study of scripture (10 minutes) Handout D--"Scripture Study"

A biblical basis for understanding the diversity within the human family.

V. Theory of the temperaments (28 minutes)

Handout E--"Temperament Profile"

Handout F--"Temperament Blends"

Handout G--"Underlying Weakness"

Handout H--"Bibliography"

A lecture and discussion of the meaning of the four temperaments types.

VI. Conflict and diversity (5 minutes) Handout I--"Conflict and Diversity"

A discussion of the relationship of conflict and human differences. 
VII. Homework assigned ( 3 minutes)

Handout J--"Biblical Conflict"

A look at conflict in scripture and how it was resolved. This homework assignment will form the basis of our discussion at the beginning of session III. 


\section{THEOLOGICAL STEPS IN CONFLICT}

\section{Diversity}

When the universe is taken as a whole, it appears to be homogeneous. In actual fact, however, diversity is common and uniformly dispersed throughout the creation (e.g., light and dark, heat and cold, wet and dry, matter and void, male and female, etc.l.

However, diversity within the creation does not necessarily lead to confusion. It would appear God's design provided a diversity within creation that would be balanced with order and harmony.

II. Tension

Diversity even within an ordered and harmonious creation would have the potential of producing certain tension. One must assume, however, that the presence of tension in creation does not represent a destructive element that denies or diminishes the balance of order and harmony. In fact, since tension is God-ordered, it might be

\section{THEOLOGICAL CONCEPTUAL MODEL OF CONFLICT}

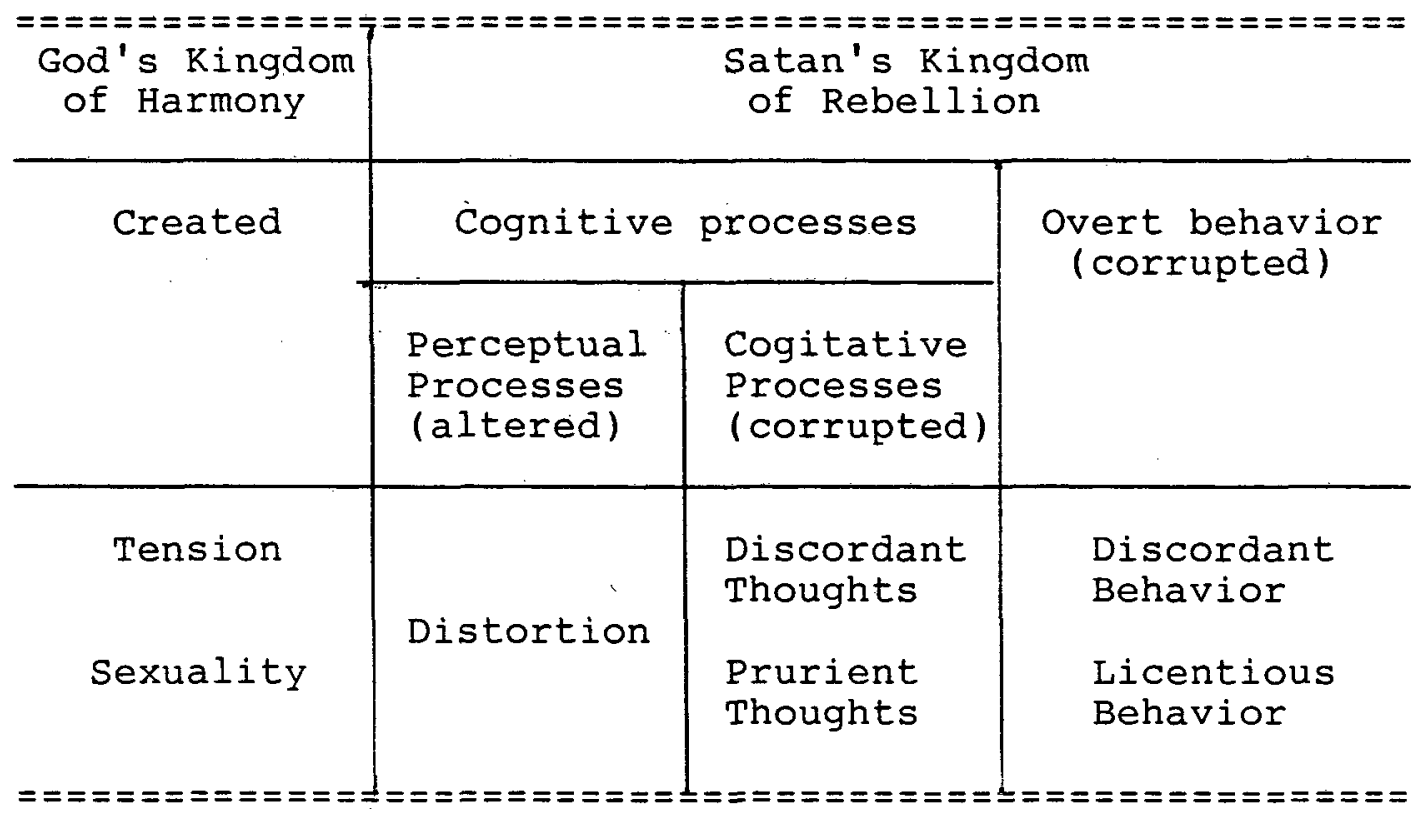


Conflict Skills Seminar

Session II

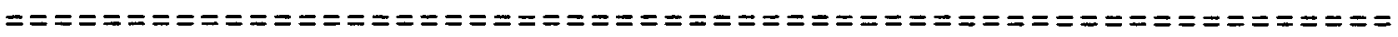
Page 2

Handout $B$

assumed that its presence is at least not opposed to order and harmony and may, in fact, be a function of it.

The presence of tension in creation is well supported by the laws of the physical sciences that regulate such things as gravity, magnetism, the molecular structure, and the atomic structure. Interestingly, in each of these, tension is a positive and constructive force that contributes to the order of the system.

God intended diversity within the human family as is witnessed by the fact that he not only created a male and female but that he created in both a reproductive system that allows for near infinite variety. Add to this that it seems that God intended for mankind to be individual thinkers and individually accountable to himself and one begins to understand that the presence of diversity could result in tension.

The orderliness of God would instruct us that this tension was not to lead to disharmony--rebellion-between humans or between humans and God. Instead, it seems logical to assume that the tension that God designed in his creation would effectively result in yet closer human relationships through deeper and more meaningful interpersonal contacts. Tension would be resolved between unfallen humans as in all other parts of creation--with balance and order.

A glimpse as to how this might work is found in $E$. G. White's description of the "counsel of peace." Here she describes a meeting between God the Father and God the son in which they discuss the plan of redemption. Though both seem agreed as to the goal (i.e., that mankind must be saved), there is "tension" over plans (i.e., how mankind is to be saved). White alludes to this tension when she describes the son "pleading with His Father" and the Father in a "struggle,.. to yield up His Son to die for the guilty race" (PP 63). This tension, however, did not result in a breakdown of communication. Instead, there is evidence that this tension contributed not only to a resolution that provided for mankind's salvation but also resulted in the defining of roles that the members 
Conflict Skills Seminar

Session II

= = = = = = = = = = = = = = = = = = = = = = = = = = = = = = = = = = = = = = = Page 3

Handout $B$

of the Godhead would take in the plan of salvation.

III. Satan's kingdom of rebellion

Even though tension may have contributed to the order and harmony of creation prior to the fall, it seems to have been through the avenue of tension that Satan broke the order and balance of creation that resulted in estrangement, separation, and alienation of interpersonal relationships.

It must be said here that one cannot attribute to Satan creative acts. There is only one creator and that is God. Satan is a creature and as a created being he has his limitations. It can be said, then, that satan did not originate conflict in the sense of creating it. Rather, it seems reasonable to assume that he used the elements already present within creation to form his society in rebellion. In effect, the destruction of order and the introduction of conflict seemingly produced by Satan resulted from his ability to alter what God had ordered (e.g., sexuality became licentiousness, diet became gluttony, worship of God became idolatry, individuality became individualism).

It can be argued, then, that God implanted in his creation the possibility of disorder and conflict by creating the diversity that produced the tension described earlier. Such would be in keeping with similar acts of God such as the creation of mankind as intentional beings with a free will and the creation of the tree of knowledge of good and evil planted in the garden of Eden to test that will.

Having said this, however, it cannot also be said that God is responsible for conflict by creating tension in his creation anymore than it can be said that God created licentiousness when he created human sexuality. Satan will have to assume the responsibility of degrading creation because he altered creation.

IV. The altered mental processes

Satan's rebellion has had two effects upon mankind's cognitive processes as it relates to the issue of conflict. First, mankind's perceptual processes have been altered. That is, mankind's 
ability to perceive and to know has been greatly affected by sin. This is due to the limitations of being human and results from the fact that people perceive reality differently based on their temperament, life-experience, and environment.

Though this perceptual distortion that mankind now experiences-results from the degraded state of God's creation, it should not be viewed as sin. While it is certainly a problem of knowing, it is not a problem of thinking. Conflict resulting from differing perceptions should be seen as a healthy conflict in that it forces us to view a matter from another's perspective.

However, conflict arising from the second mental process is far more serious. The cogitative processess involve the thinking or contemplative processes; it is what humans allow their minds to dwell upon. Discordant thoughts entertained here is far more than merely a perceptual difference; it is a perceptual difference nurtured, dissected, and reconstructed by the active thinking processes. It is akin to prurient thoughts in the sexual area. Prurience is more than a perceiving that two people differ biologically (perception), it is an active thinking of lewd (lascivious) thoughts.

Dwelling on lustful thoughts results in awakening and nurturing certain emotions (e.g., desire, passion, etc.) that may eventually lead one to commit a lustful act. Likewise, dwelling on discordant thoughts results in awakening and nurturing certain emotions (e.g., anger, bitterness, fear, etc.) that may eventually lead one to engage in discordant behavior.

It is at this point that sin enters. Just as prurient or lustful thoughts lead to licentious (immoral) behavior so discordant thoughts lead to discordant behavior.

Prov 23:7--"For as he thinketh in his heart, so is he."

Matt 5:28--"But I say unto you, that whosoever looketh on a woman to lust after her hath committed adultery with her already in his heart." 


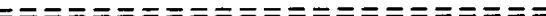

\section{TEMPERAMENT INVENTORY}

The "Temperament Inventory" instrument will not only help us to better understand ourselves but will also help us to understand and appreciate others. 


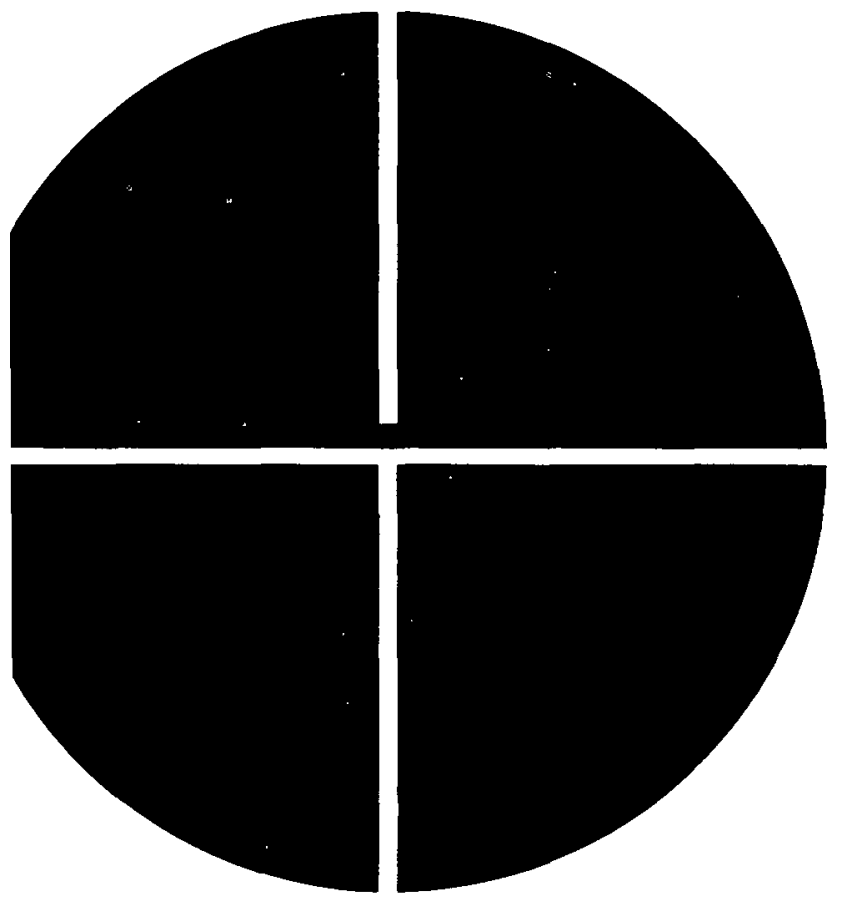

Please fill in the information requested below.

A Name

$\hat{\Delta}$ Mailing Address

A Phone number

$\Delta$ Sex

\section{Directions:}

This is an inventory of temperament, and not of "emotional adjustment." There are no better or worse temperaments, only different ones. Neither are there any right or wrong answers. You can indicate whether a statement describes you or not by blackening in the space under the column headed YES or NO.

Only if you are absolutely honest in answering the statements will the test be of any real help to you in understanding yourself.

There is no time limit, but work rapidly and do not spend too much time on any one item. Be sure to answer every item. Now turn over your booklet and begin.

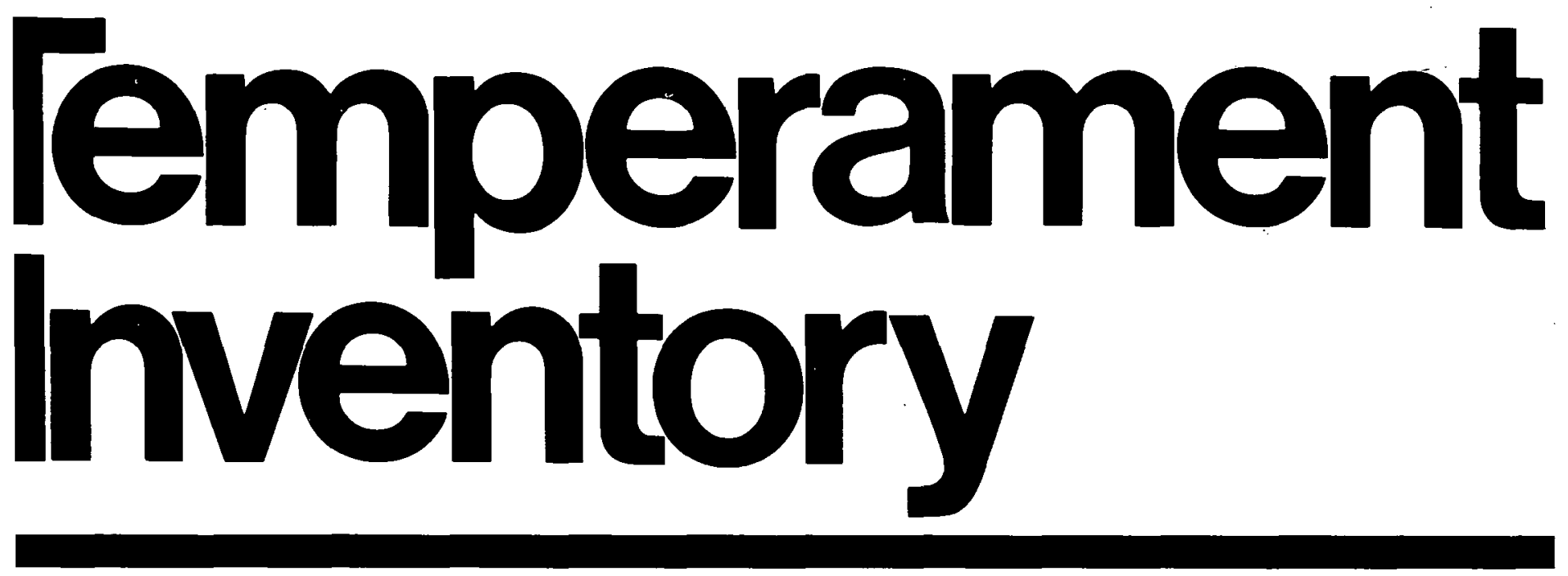

רed by

vs University Press I Springs, Ml 49104

ght (C) 1977

hts Reserved by

Robert J. Cruise, Ph.D.

W. Peter Blitchington, Ph.D. 


\section{Put your answers to this page in Column 1.}

1. I succeed when some people fail, not because my plans are better, but because I keep pushing when they get discouraged and quit

2. My calm, tranquil nature usually keeps me from getting upset in the face of external turmoil or stress.

3. I seem to be able to diagnose fairly accurately the obstacles and dangers of projects I am planning

4. I'm annoyed by the enthusiasm of some people, and I guess I kind of needle them sometimes

5. I usually allow other people to meet me, rather than pushing forward to meet them.

6. My leadership ability is more the result of drive and persistence than charisma.

7. I am not able to converse easily with other people, but I'm pretty good at sizing them up and analyzing them.

8. I frequently find myself arriving late for engagements and forgetting resolutions.

9. I am more the kind of person who is deeply loyal to the few friends I have than the kind of person who has a lot of friends.

10. I tend to be motivated by the crowd (or situation). If they are busy I get busy, if they aren ' $\mathrm{I}$ 'm not

11. I am self-motivated. If something is there to be done, I can't be satisfied until I've completed it.

12. I usually prefer solitary activities, such as reading, to activities which involve other people

13. I go over and over decisions after I make them, asking myself if I chose right.

14. I sometimes only halfheartedly help others because deep down inside I think I have a better plan and an easier way.....

15. I tend to remember when people have insulted me and to think about it every now and then.

16. I really enjoy myself, and my attitude seems to be contagious to those around me.

17. In my introspection ! tend to relive over and over again the events of the past.

18. I have a fairly keen mind and can usually plan worthwhile long-range projects

19. I'd probably be more sociable if I weren't afraid people would reject me.

20. I like to be where there is something going on all the time.

21: It makes me gloomy when other people ignore or avoid me.

22. Some people say that I am a born leader because of my tendency to "take over.'

23. I know where I want to go and I usually discipline myself to get there.

24. I have a tendency to hold grudges against people who are rude to me.

25. I tend to be emotional. Things arouse or upset me pretty easily.

26. It usually takes something drastic to get me excited or upset.

27. I have a rather even-tempered emotional response to things. 
Put your answers to this page in Column 2.

28. Sometimes when I see two people laughing, I wonder if they're laughing at me.

29. I have a pretty even disposition, not too many ups and downs. .

30. My friends would describe me as relaxed and even-tempered.

31. I should have more self-confidence; I tend to under-estimate my abilities.

32. If a job needs to be done I do it regardless of how unpleasant it is.

33. I tend to reflect a good deal on my dreams, hopes, and aspirations.

34. I can put up with frustration without becoming depressed or angry.

35. I make new friends so easily that I tend to forget old friends.

36. | wouldn't mind belonging to several clubs at the same time.

37. I have a tendency to think gloomy, pessimistic thoughts.

38. I often have trouble finishing things that I've started.

39. In social situations, I am talkative and spontaneous.

40. I am usually uncomfortable in a group of people.

41. I enjoy people and just like to be around them.

42. I should probably be less moody and sensitive.

43. I have a somewhat defensive, touchy nature

44. Sometimes I think about getting revenge for old wrongs.

45. Adversity just stimulates me to push a little harder.

46. I am somewhat serious and very deeply emotional.

47. I like to spend time planning things way ahead of time.

48. I have a warm spirit. I am lively and enjoy living

49. By nature I seem to be a pretty good "peacemaker."

50. My friends consider me to be a tactful person

51. I tend to be pretty tolerant of other people.

52. I am usually very well organized in my work

53. When things go wrong I knuckle down and try harder.

54. I have a pretty good ability to get things done. 
Put your answers to this page in Column 3 .

55. I am calm and relaxed, and rather unemotional.

56. I tend to get my feelings hurt fairly easily

57. I see myself as a cheerful, sociable person.

58. I have a tendency to feel sorry for myself.

59. Socially, I am a pretty outgoing person

60. A strong will is one of my best assets.

61. I usually have a good time at parties.

62. I usually make new friends easily.

63. My life is fast-paced and active.

64. I need to learn to worry less

65. I tend to move and speak slowly and calmly

66. I have a tendency to brood about things.

67. I tend to be a pretty easygoing person.

68. I usually finish whatever I begin.

69. I don't get upset very often.

70. I'm rarely at a loss for something to say.

71. I usually get a lot of fun out of life

72. My friends would call me an extrovert.

73. I tend to analyze myself frequently.

74. Unfinished tasks really bother me.

75. I don't get ruffled easily.

76. I tend to be a hard, persistent worker.

77. I tend to resent people who oppose me

78. I seldom get angry or overemotional.

79. I don't make friends very easily

80. I should probably be less lazy. 


\section{SCRIPTURE STUDY}

Directions: Read the following portions of scripture and then discuss the questions with your group.

"Now there are varieties of gifts, but the same Spirit; and there are varieties of service, but the same Lord; and there are varieties of working, but it is the same God who inspires them all in every one. To each is given the manifestation of the spirit for the common good." 1 Cor 12:4-7 (RSV).

"For just as the body is one and has many members, and all the members of the body, though many, are one body, so it is with Christ.. . For the body does not consist of one inember but of many... As it is, there are many parts, yet one body. The eye cannot say to the hand, 'I have no need of you,' nor again the head to the feet, 'I have no need of you.' on the contrary, the parts of the body which seem to be weaker are indispensable, and those parts of the body which we think less honorable we invest with the greater honor, and our unpresentable parts are treated with greater modesty, which our more presentable parts do not require. But God has so composed the body, giving the greater honor to the inferior part, that there may be no discord in the body, but that the members may have the same care for one another. If one member suffers, all suffer together; if one member is honored, all rejoice together." 1 Cor 12:12,14-26 (RSV).

1. What does the body represent in this scripture?

2. What is meant by the various parts of the body?

3. Who is the responsible for the diversity within the body?

4. What is the purpose of diversity within the body?

5. What general conclusions can we draw regarding human diversity? 
Conflict Skills Seminar

Session II

$====$
Page 1

Handout $E$

TEMPERAMENT PROFILE

I. Introduction

The following pages outline the characteristics of the four temperament types: Sanguine, Choleric, Phlegmatic, and Melancholy.

As you study the temperament types, you will discover insights that will not only help you to understand your own attitudes, feelings, and actions but also the attitudes, feelings, and actions of others.

More than 400 years before Christ, Hippocrates, a Greek physician and philosopher, developed a theory that there are basically four types of temperament. This theory has had wide acceptance over the years. Most scientific work on the temperaments has been done by British psychologist Hans Eysenck. Most recently, authors Tim LaHaye (Spirit Controlled Temperament) and Florence Littauer (pérsonality Plus) have popularized the theory in the Christian community. The instrument used in this seminar was developed by Peter Blitchington and Robert Cruise, professors at Andrews University.

II. Definitions ${ }^{1}$

A. Temperament is the combination of inborn traits that subconsciously affects our behavior. These traits are arranged genetically and are passed on by the genes.

B. Character is the real "you." It is the result of your natural temperament modified by childhood training, education, and basic attitudes, beliefs, principles, and motivations.

C. Personality is the outward expression of ourselves which may or may not be the same as our character, depending on how genuine we are. Often personality is a pleasing facade for an unpleasant or weak character.

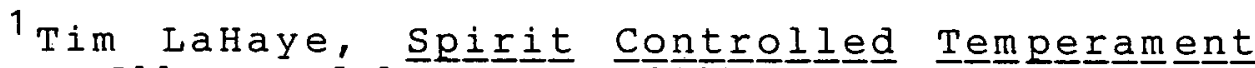
(Wheaton, Il1.: Tyndale House, $19 \frac{1}{82}$ ), pp. $5-\frac{1}{6}$. 
The temperament is the combination of traits we were born with; character is our "civilized" temperament; and personality is the "face" we show to others.

III. Three Notes of Caution

A. As we discuss these four types of temperament, bear in mind that no person is a singletemperament type. Instead, we are a combination of the four with one usually predominating above the rest.

B. People are individuals who are far more complex than indicated by this model alone. Though this model will likely open a new world of understanding to you, remember that it does not have all of the answers. As a result, you are misusing this tool if you pigeonhole people into a category without taking into account how they may differ from the "norms" or how they may be empowered to be different by the Spirit.

C. There is also a danger that this tool might be used as an excuse for negative behavior. While it is true that each temperament has its own list of weaknesses, we must remember that weaknesses are to be overcome in Christ. 


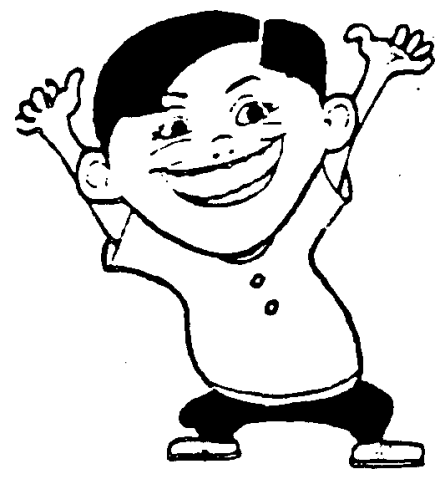

\section{Sanguine}

183

EMOTIONS
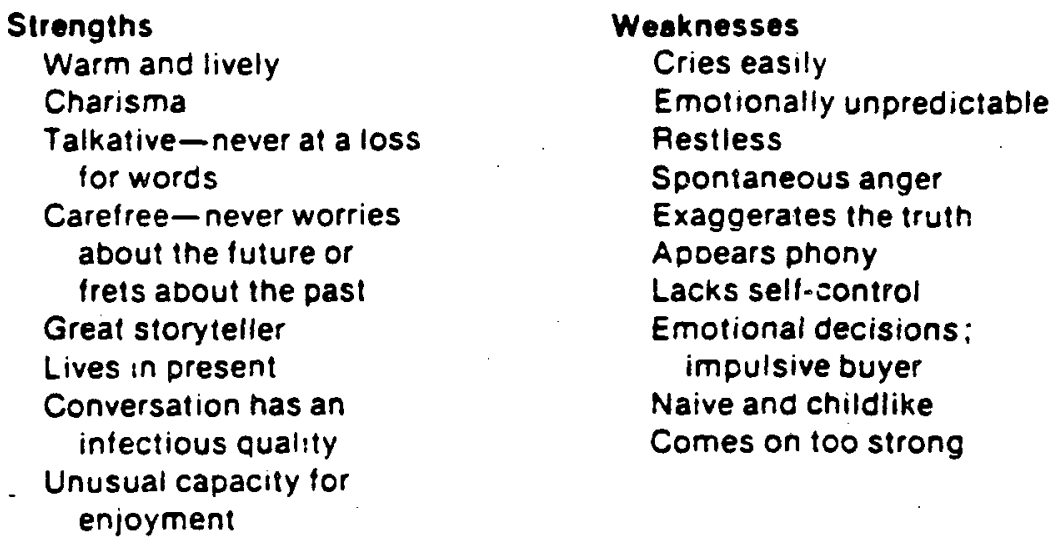

RELATIONSHIP TO OTHERS

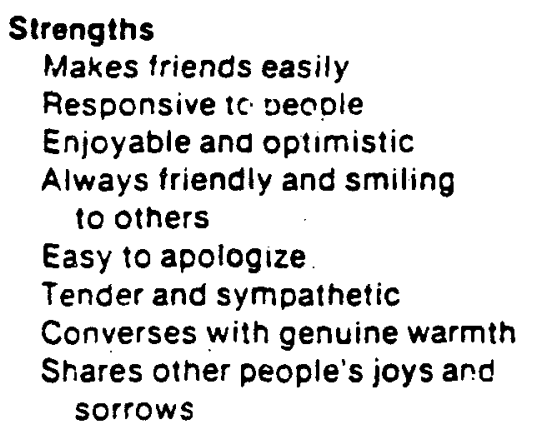

Sirengths

Makes good first impression

Nol bored because living in the

ine present

Gifted in caring for the sick

Easily engages in new plans or projects

Breeds entnusiasm

\author{
Weaknesses \\ Dominates conversation \\ Not attentive \\ Weak-willeo ano little conviction \\ Seeks credit and approval \\ Enjoys people and then \\ forgets them \\ Makes excuses for negligence \\ Talks 100 often about self \\ Forgets promises and obligations
}

\section{ACTIVITIES}

\author{
Weaknesses \\ Completely disorganized \\ Undependable; late \\ Undisciplined \\ Wastes time talking when \\ should be working \\ Many unfinished projects \\ Easily distracted \\ Falls short of goal
}

\section{OCCUPATION AND HOBBIES}

Public speaker

Actor or aciress

Courtroom lawyer

Salesman or saleswoman

Preacher

Athletic director

Receptionisi
Visiting and caring for sick

Volunteer worker

Given to hospitality

Participant in athletics

Loving parent

\section{GREATEST NEEDS}

To be more reliable and dependable

To develop a grearer self-disciplined life

To replace ego with genuine humility 


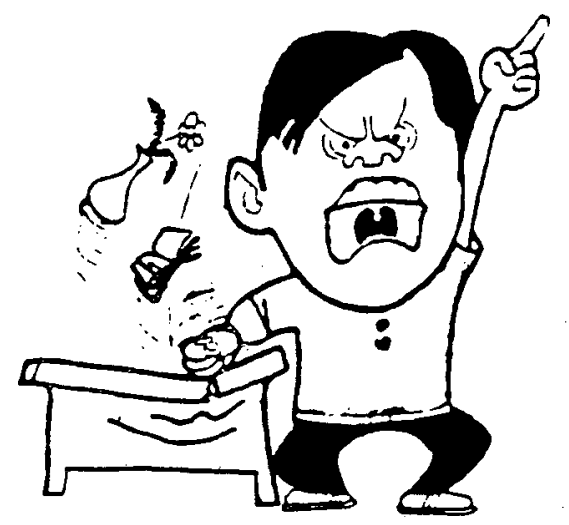

\title{
Choleric
}

\section{EMOTIONS}

\author{
Strengths \\ Confident and strong \\ to make decisions \\ Strong-willed and self- \\ determined \\ Optimistic \\ Sell-sulficient \\ Fearless and bold
}

\author{
Weaknesses \\ Violent anger problem \\ Highly opinionated \\ Insensitive to needs of others \\ Unemotional and cold \\ Little appreciation for \\ aesthetics \\ Unsympathetic and harsh \\ impeivous and violent \\ Disgusted by tears
}

\section{RELATIONSHIP TO OTHERS}

\section{Strengths}

Does not expect anyone else to do something sine can't do

Not easily discouraged

Strong leader

Good judge of people

Motivator of others

Exhorter

Never daunted by circumstances

\author{
Weaknesses \\ Lack of compassion \\ Makes decisions for others \\ Cruel, blunt, and sarcastic \\ Tends to dominate a group \\ Arrogant and bossy \\ Uses people for own benefit \\ Unforgiving and revengeful \\ Prone to bigotry \\ Haughty and domineering
}

\section{ACTIVITIES}

\section{Strengths}

Good organizer and promoter

Decisive; intuitive ability to make decisions

Quick and bold in emergencies

Keen, quick mind

Greal capacity for action

Does not vacillate

Very pracical

Stimulates others to activity

Thrives on opposition

Sets goals and reaches them

\section{Weaknesses}

Overly selt-confident

Crafty

Prejudiced

Opinionated

Bored by details

Non-analytical

Forces others to agree to plan of work

Tiresome and hard to please

Only time for own plans or projects

OCCUPATION AND HOBBIES

Manager/Leader

Producer

Builder/Organizer

Promoter

Educator

Executive
President

Crusader

Home entertainer

Participant in athletics

\section{GREATEST NEEDS}

To become sensitive to the needs of others

To confess angry and cruel spirit

To develop inner strength and beauty by quiet hours spent reading the Bible and praying 


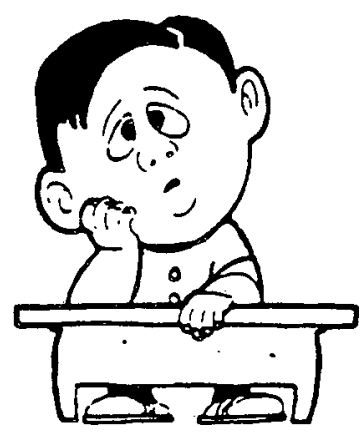

\title{
Phlegmatic
}

\section{EMOTIONS}

\section{Strengths}

Calm and dependable

Good-natured and easy ta get along with

Cheertul and pleasant even it doesn't have much lo say

Kind-hearted

Peace-loving

\author{
Weaknesses \\ Lacks confidence in self \\ Pessimistic and fearful \\ Worrier \\ Rarely laughs aloud \\ Passive and indifferent \\ Compromising \\ Self-righteous
}

\section{RELATIONSHIP TO OTHERS}

\section{Strengths \\ Pleasant to be with \\ Has many friends \\ Dry, witty sense of humor \\ Softening and conciliating \\ effect upon others \\ Constant and faith'ul \\ Diplomatic and peacemaker \\ Good listener \\ Faithful friend \\ Gives advice only when asked}

\author{
Weaknesses \\ Doesn't allow self to get involved \\ Selfish and stingy \\ Siudies people with indifference \\ Unenthusiastic \\ Siubborn \\ Indifferent about others \\ Feases others who annoy him/her \\ Not too cordial \\ Altitude of superiority
}

\section{ACTIVITIES}

\author{
Strengths \\ Works well under pressure \\ Practical, easy way of working \\ Eonservative \\ Neat and proficient \\ Plans work before beginning \\ Stabilizing influence \\ Dependable worker
}

\author{
Weaknesses \\ Calm, serene, uninvolved spec. \\ tator in lite \\ Slow and lazy \\ Reluctant leader. \\ Lack of motivation \\ - Indecisive \\ - Overprotects self from involvernent \\ Discourages others \\ Opposes change of any kind
}

\section{OCCUPATION AND HOBBIES}

Accountant

Technician

Diplomat

Elementary Education teacher

Social Worker

Counselor

Crafts
Administrator

Seamstress

Secretary

Spectator of athletics

Good mother/father

\section{GAEATEST NEEDS}

To overcome passivify

To learn to give of self to others

To stop acting like a Christian and really be one

To recognize fearfulness as a sin

and cope with it accordingly 


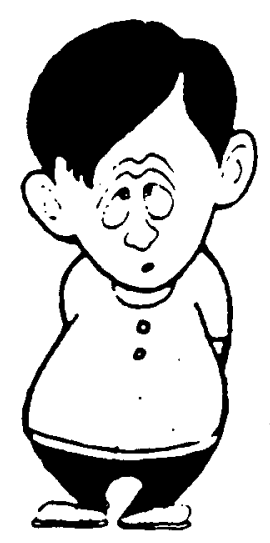

\section{Melancholy}

\section{EMOTIONS}

\section{Strengths}

Loves music and ark

Rich, sensitive nature

Analytical ability

Emotionally responsive

Deep, reflective thinker

\author{
Weaknesses \\ Moody and gloomy \\ Pessimistic; always looking \\ on the negative \\ Likes to sutfer; martyr \\ Hypochondriac \\ Introspective to the point \\ of being harmful \\ Depression \\ Proud
}

\section{RELATIONSHIP TO OTHERS}

\section{Strengths}

Dependable friend

Self-sacrificing friend

Faithful and loyal triend

Makes friends cautiously

Deep feeling for friends

\section{Weaknesses}

Critical of others' imperfections

Searches for perfection and jucges everything according to own ideas

Fearful of what others think

Suspicious of others

Can erupt into violent anger after prolonged animosity

Often deeply hurt by others

Will carry a grudge and be revengeful

Dislikes those in opposition

Hard to get along with

\section{ACTIVITIES}

\author{
Strengths \\ Strong perfectionist tendencies \\ Likes detail and analytical \\ work \\ Self-disciplined; finishes \\ what $s /$ he undertakes \\ Fitted for creative, \\ intellectual work \\ Conscientious and thorough \\ Gitted; genius-prone \\ Knows own limitations
}

\author{
Weaknesses \\ Indecisive \\ Theoretical and impractical \\ Tires easily \\ Hesitant to start a new project \\ Too much analysis: leads to dis- \\ couragement \\ Life work must demand the greatest \\ in sacrifice, self-denial and \\ service \\ Gets moody over creations
}

\section{OCCUPATION AND HOBBIES}

Professor
Philosopner
Inventor
Physician/Nurse
Musician

Professor

Inventor

Musician
Antist

Seamstress

Accountant

Beautician

Spectator at athletic events
Interior Decorator

Fashion Designer

Author

Crafts

Poel-either to write or to enjoy

\section{GREATEST NEEDS}

To overcome critical spirit

To be delivered from self-absorption

To become occupied in loving service for orners, thus forgetting self

To develop a thanksgiving spirit 
TEMPERAMENT BLENDS ${ }^{1}$

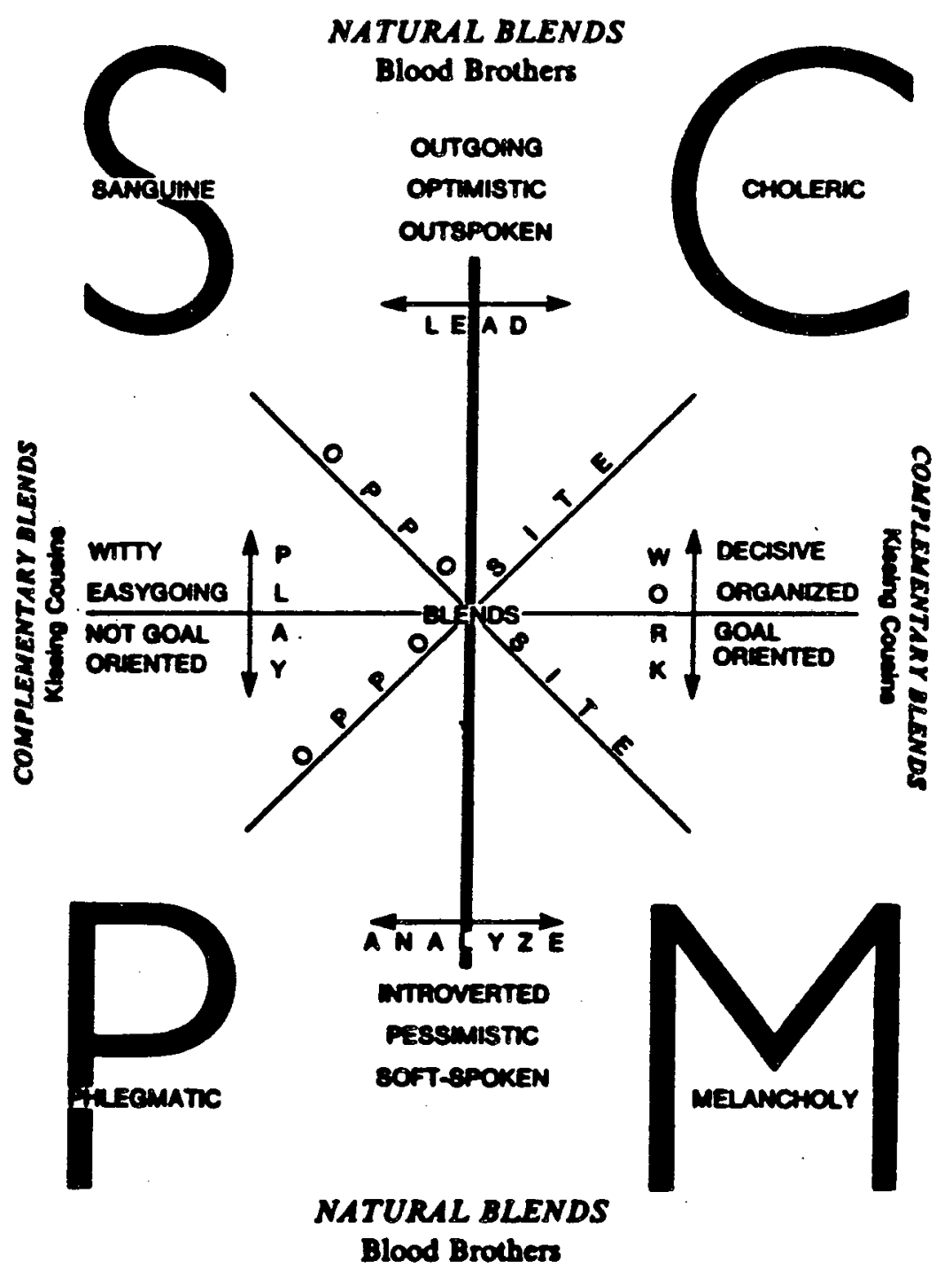

${ }^{1}$ Florence Littauer, Personality Plus (Old Tappan, New Jersey: Fleming H. Revell, 1983), p. 142 . 


\section{UNDERLYING WEAKNESS ${ }^{1}$}

EXTROVERT

Sanguine

Weak-willed

Restless

Egotistical

Emotionally unstable

Choleric

Self-sufficient Impetuous

Cruel

Hot-tempered

INTROVERT

Melancholy

Moody

Self-centered

Critical

Pessimistic

Phlegmatic

Indolent

Teasing

Stubborn

Indecisive

\section{Anger}

Sellfishness

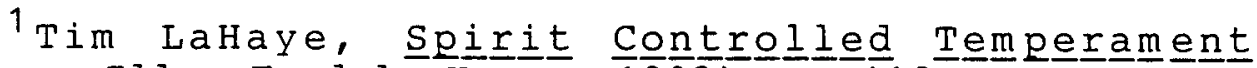
(Wheaton, Ill.: Tyndale House, 1982 ), p. 112 . 
Blitchington, Peter, and Cruise, Robert J. Understanding Your Temperament. Berrien Springs, Mich.: Andrews University Press, 1979.

LaHaye, Tim. Sppirit Control led Temperament. Wheaton, Ill.: Tyndale House, 1982.

Transformed Temperaments. Wheaton, Ill.: Tyndale House, 1983 .

- Understanding the Male Temperament old Tappan, New Jersey: Fleming H. Revell, 1977.

- Your Temperament Can Be Changed. Wheaton, I11.: Tynda le House, 1983.

Littauer, Florence. Personality $\underline{\text { Plus}}$ s. Old Tappan, New Jersey: Fleming H. Revell, $19 \overline{83}$.

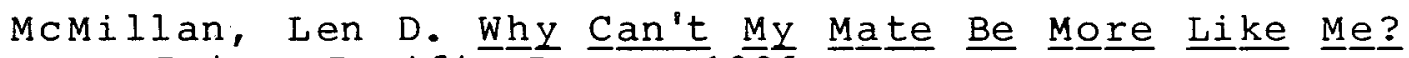
Boise: Pacific Press, 1986. 
Conflict Skills Seminar

Session II

= = = = = = = = = = = = = = = = = = = = = = = = = = = = = = = = = = = = = = = = = =

Handout I

\section{CONFLICT AND DIVERSITY 1}

Diversity or pluralism is a way of saying that there is more than one way to live. In fact, it goes further and says there is more than one race, one sex, one ideology, one culture, one way to worship, or one way to look at a problem. To accept other ideas as good is to recognize diversity in God's creation and to echo his blessing that "it is good."

Diversity is as much a state of mind as anything else. The world has known for centuries that there are varieties of peoples, cultures, beliefs and institutions. What the leaders of the world have not acknowledged is that diversity must be dealt with by allowing all people to have rights and privileges that only leaders have enjoyed.

Diversity is a positive force in society and in the church for several reasons.

1. Diversity allows for the surfacing of ideas and concerns that can spark new ways of acting and thinking.

2. Diversity increases the possibility of innovation.

3. Diversity encourages the development of good and sensitive leaders.

Diversity, however, can be painful. Diversity may be seen as a threat by some especially as new approaches to old problems are suggested and explored. The real danger, however, is that those threatened will close communication caused by an inability or unwillingness to listen to each other.

The presence of diversity demands that the leadership in the church be better in the future. Leaders must be skilled in negotiations, in dealing with conflict in an open and even manner, in the ability to act deliberately and considerately rather than running about at every whim of the largest giver, and in involving many people in the decision making processes.

${ }^{1}$ Adapted from Douglas $W$. Johnson, Managing Change in the Church (New York: Friendship Press, 1974), pp. 10-17. 
Conflict Skills Seminar

Session II

= = = = = = = = = = = = = = = = = = = = = = = = = = = = = = = = = = = = = = Page 1

Handout $J$

BIBLICAL CONFLICT ${ }^{1}$

Barnabas and Paul Jerusalem with John Mark Council

(Acts 15:36-39) (Acts 15:1-31)

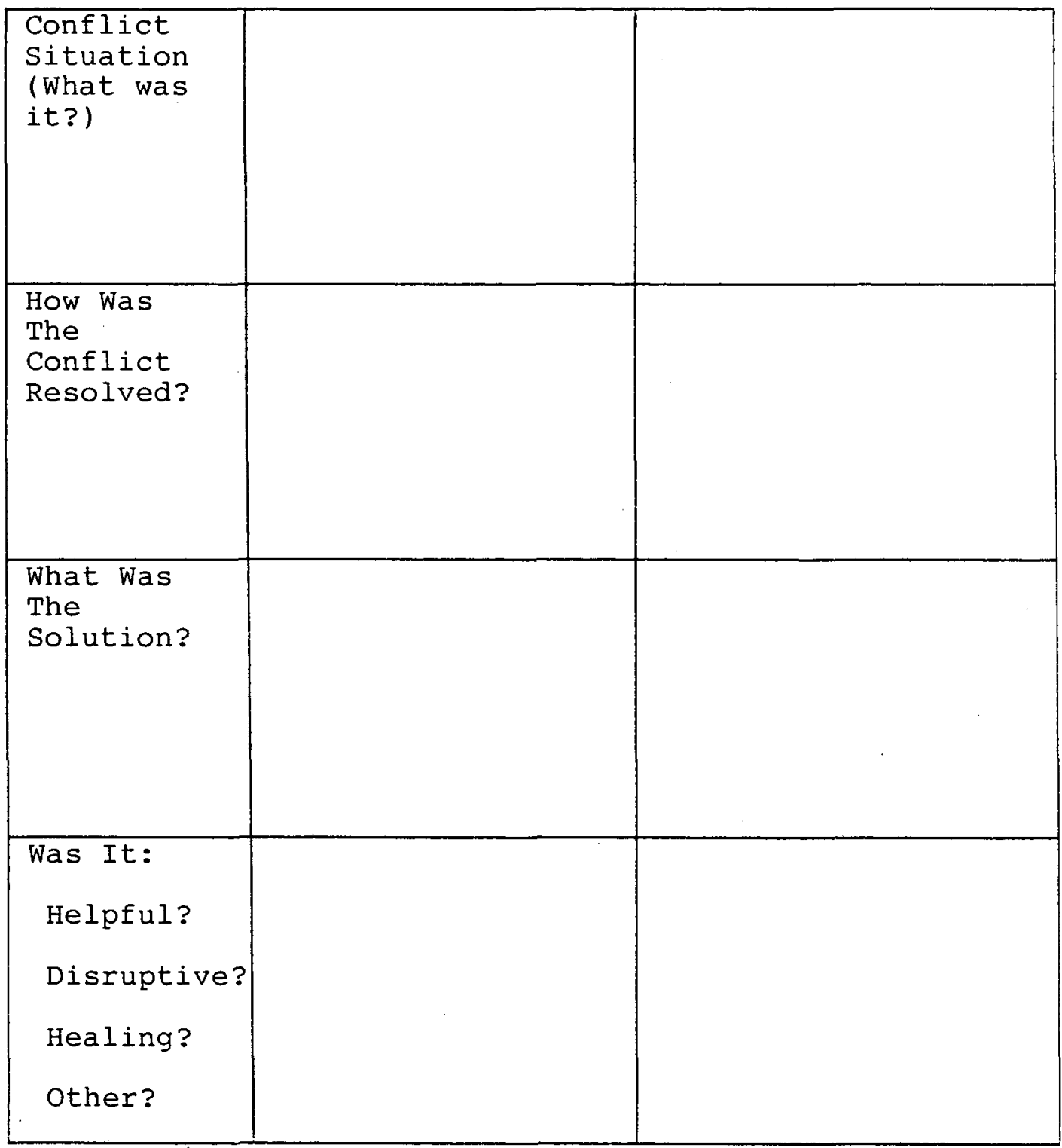

1 Adapted from Lynn Buzzard and Juanita Buzzard, Resolving Our Differences (Elgin, Ill.: David C. Cook Publishing, 1982), p. 21 。 
Conflict Skills Seminar

Session II

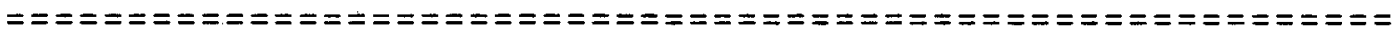
Page 2

Handout $\mathrm{J}$

$\begin{array}{lll}\text { Peter and } & \text { James and } & \text { Deacons } \\ \text { Paul } & \text { John } & \text { (Acts 6:1-5) } \\ \text { (Gal 2:6-21) } & \text { (Mark 10:35-45) } & \end{array}$

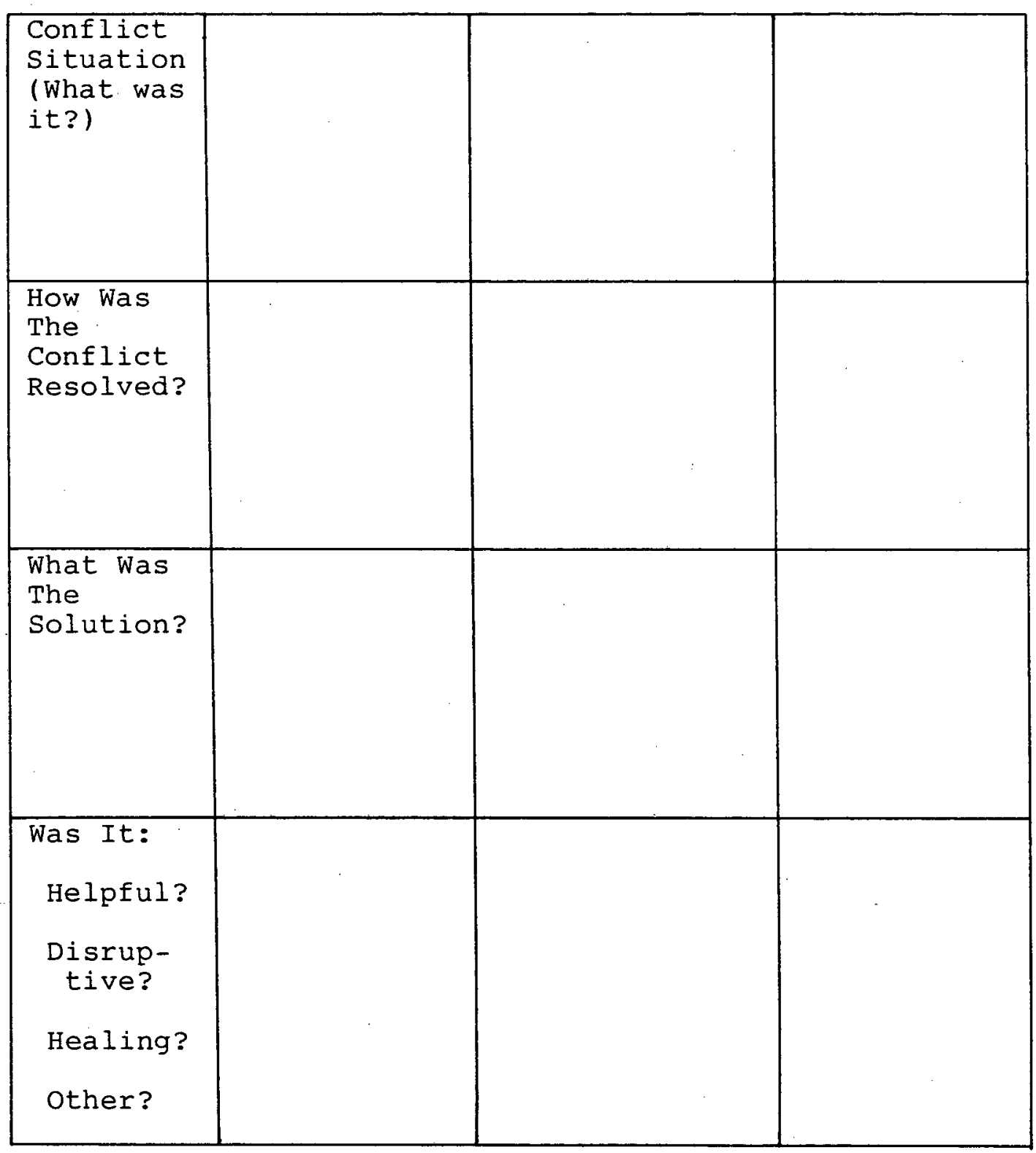


"YOU CAN CHANGE THE COURSE OF CONFLICT" OUTLINE

I. Pre-session

Handout A--"Outline"

II. Negative and positive results of conflict $110 \mathrm{~min}$ utes)

Handout B--"Negative Results of Conflict"

Handout C--"Positive Functions of Conflict"

A discussion of the negative results and positive functions of conflict.

III. Biblical conflict ( 20 minutes)

A discussion of several examples of conflict in the Bible using Handout J ("Biblical Conflict") from Session II. The purpose is to show that there can be positive results from conflict.

IV. The Conflict Management style test (10 minutes) Handout D--"Conflict Management Style Test"

A testing instrument that analyzes one's preferred conflict management style.

V. Theory of conflict management styles (30 minutes)

Handout E--"Conflict Management styles Scoring Sheet"

Handout F--"Conflict Styles"

Handout G--"Two Dimensional Model of Conflict Behavior"

A discussion of six ways of managing conflict.

VI. Small group practice of the conflict styles 117 minutes)

Handout H--"Small Group Practice of the Management styles"

A small group practice of the conflict management styles.

VII. Homework assignment ( 3 minutes)

Handout I--"Personal Conflict Evaluation"

A reflection exercise for the purpose of selfevaluation. 
= = = = = = = = = = = = = = = = = = = = = = = = = = = = = = = = = = = = = = = = = = = Page 1

Handout $B$

\section{NEGATIVE RESULTS OF CONFLICT ${ }^{1}$}

I. Negative Results of Conflict

A. Disintegration

The church uses up its resources (losing members, money, and energy) on unhealthy conflict.

B. Dysfunction

The church spends energy on nonproductive issues.

C. Dissociation

The church experiences the agony of interpersonal hostility.

II. Symptoms of Conflict in the Church

internal division

members informally organizing cliques and factions increasing use of voting to make decisions

long-drawn-out, personally unfulfilling meetings

sharply increased attendance at certain meetings decreasing attendance over the long run

increased use of hostile language

experiencing other members as enemies

feelings of fear that the organization is out of control

sons of light versus sons of darkness

win/lose attitudes in decision-making

people looking for conspiracies

conspiracies

increased discussion about the goals of the church indicating a breakdown of consensus

increased incongruity between what people say at meetings and what they say over the phone concerning church matters

unfocused anxiety and anger

displacement: people looking for reasons to disagree without naming (or sometimes without knowing) the "real" problem

${ }^{1}$ Adapted from speed Leas and Paul Kittlaus, Church Fights (Philadelphia: Westminster Press, 1973), pp. 1617 . 
acting out: overresponding or other incongruous behavior

blocks of pledges not being paid

members transferring membership

every issue at every meeting experienced as part of a larger struggle

communication patterns change

friendship patterns change

increasing mistrust of others

painful pressure on the minister, evidenced by increased use of the theme of reconciliation in sermons, prayers, and hymns

minister developing a sense of personal failure job-hunting by the minister

increased calling/letter writing to the conference

increased use of and dependence on procedural rules

III. The Conflict Experience

Conflict is an inevitable feature of social life and it is experienced at every level of the social structure.

Intrapersonal

Intragroup

Intraorganization

Intranational
Interpersonal

Intergroup

Interorganization

International 


\section{POSITIVE FUNCTIONS OF CONFLICT}

Most of us readily agree that conflict has negative consequences. However, conflict also has positive results. In fact, some of the positive functions of conflict are essential to organizational life giving it vitality to accomplish its mission. Some of the positive results of conflict are as follows:

Conflicts allow important issues to be aired; they produce new and creative ideas; they release built-up tension; they can strengthen relationships; they can cause groups and organizations to reevaluate and clarify their goals and missions; they can also result in social change to eliminate inequities and injustice. 1

Conflicts may increase the motivation and energy available to do tasks required by the social system; they may increase the innovativeness of individuals and the system because of the greater diversity of the viewpoints and a heightened sense of necessity; each person may develop increased understanding of his own position because the conflict forces him to articulate his views and to bring forth all supporting arguments; each party may achieve greater awareness of his own identity; interpersonal conflict may be a means for managing the participants' own internal conflicts.

While it is true that too much conflict can immobilize a group, tolerable levels of conflict can do the following: ${ }^{3}$

increase group cohesiveness, energize group life, establish or increase group identity, unify the ingroup,

helps the members of the group bear the intolerable.

1 Joseph P. Folger and Marshall scott Poole, Working Through Conflict (Glenview, Ill.: Scott, Foresman and Co., 1984), p. 1 .

${ }^{2}$ Richard E. Walton, Interpersonal Peace (Reading, Mass.: Addison-Wesley, 1969), p. v.

${ }^{3}$ Speed Leas and Paul Kittlaus, Church Fights (Philadelphia: Westminster Press, 1973), pp. $\frac{1}{35}-41$. 
Conflict Skills Seminar

Session III

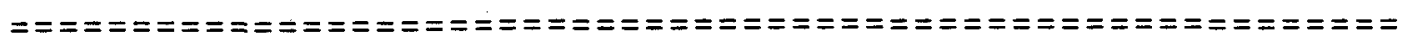
Page 1

Handout $D$

\section{CONFLICT MANAGEMENT STYLE TEST ${ }^{1}$}

Instructions: Choose a conflict "setting" in which you are sometimes or often in conflict. You should not attempt to think of yourself "in general" or in a variety of settings, but in one particular environment. A "setting" is an environment, or organization, or relationship which has significance for you as distinct from other settings or relationships. For example, a setting might be your relationship with your spouse as distinct from your relationship with your children; it might be your relationship with your co-workers or with your boss; it might be your relationships at church, or on a particular community board.

People tend to get different scores as they think of themselves in each setting. So, you may wish to fill out the instrument for more than one environment in order to get a more accurate picture of your preferred conflict management style.

It is not a good idea to choose one particular conflict that may have occurred in a setting. Rather, let yourself be reminded of several conflicts that may have occurred in that setting. Moreover, do not choose the worst conflict that you may have experienced in this setting. Try to reflect on yourself in the usual and regular situations that you get into, as. well as those which may have been particularly tough or easy.

Answer each question with a response that is as close as it can be to how you usually respond in this conflict setting. Each question contains a pair of statements describing possible behavior responses. For each pair, circle the "A" or "B" statement which is most characteristic of your own behavior.

In many cases, neither " $\mathrm{A}$ " nor " $\mathrm{B}$ " may be very typical of your behavior; nonetheless, please select the response which you would be more likely to make.

${ }^{1}$ Speed Leas, Discover Your Conflict Management Style (Washington, D.C.: Alban Institute, 1984), pp. 1-4. 


\section{Instrument:}

1. A. Using logic, I try to convince the other of the value of my position.

B. I use whatever authority I have to convince the other of my position.

2. A. I let others take responsibility for solving the problem.

B. I seek the other's help in working out a solution.

3. A. I try to find a compromise solution.

B. I actively listen to the other.

4. A. I make an effort to get my way.

B. I will make an effort to go along with what the other wants.

5. A. I don't let others abuse my rights.

B. I show empathy about his/her plight.

6. A. I try to surface all of his/her concerns.

B. If I give up something, I expect the other to give up something.

7. A. I press my argument to get points made.

B. I attempt to work on all concerns and issues in the open.

8. A. I assert my rights.

B. I will give up some points in exchange for others.

9. A. I might try to soothe the other's feelings to preserve our relationship.

B. I encourage the other to act for himself/herself.

10. A. I tell him/her my ideas.

B. I propose a middle ground.

11. A. I remind the other I am an authority on the subject we are dealing with.

B. In order to keep the peace, I might sacrifice my own wishes for those of the other. 
12. A. I invite the other to join with me to deal with the differences between us.

B. I assume that giving advice creates dependence on me.

13. A. I try to show him/her the logic of my position.

B. I usually repeat back or paraphrase what the other has said.

14. A. I use the constitution or policy manual as a backup for my position.

B. I encourage the other to stay with me in the conflict.

15. A. I try to do what is necessary to avoid useless tensions.

B. If it makes the other happy, I might let him/her retain some of his/her views.

16. A. I subtly threaten our relationship if I don't get my way.

B. I am firm in pursuing my argument.

17. A. I am concerned with satisfying all our wishes.

B. I try to avoid unpleasantness for myself.

18. A. I don't try to persuade another about what should be done. I help him/her find his/her own way.

B. I try to find a fair combination of gains and losses for both of us.

19. A. I try to postpone the issue until a later time.

B. I try to show the logic and benefits of my position.

20. A. I am non-judgmental about what the other says or does.

B. I call in an authority who will support me.

21. A. I try to find an intermediate position.

B. I usually seek the other's help in working out a solution. 
22. A. I tell the other about the problem so we can work it out.

B. I propose solutions to our problems.

23. A. I usually ask for more than I expect to get.

B. I offer rewards so the other will comply with my point of view.

24. A. I try not to give advice, only to help the other find his/her own way.

B. Differences are not always worth worrying about.

25. A. I calculate about how to get as much as I can, knowing I won't get everything.

B. I try to gain the other's trust in order to get him/her on my side.

26. A. I sometimes avoid taking positions which would create unpleasantness.

B. I pout or withdraw when I don't get my way.

27. A. I help the other take care of his/her own problems.

B. When someone avoids conflict with me, I invite him/her to work it out with me.

28. A. I try to put as little of myself forwardas possible, attempting to utilize the strengths of others.

B. I point out the faults in the other's arguments.

29. A. When someone threatens me, I assume we have a problem and invite him/her to work it out with me.

B. When I am right, I don't argue much; I just state my position and stand firm.

30. A. I will give in a little so everybody gets something he/she wants.

B. I try not to hurt the other's feelings.

31. A. I carefully prepare my case before joining the argument.

B. I admonish the other to do as I say. 
32. A. I try to be considerate of the other's wishes.

B. If we are at a loss as to how to work as issue through, we ask for a third party.

33. A. In order to succeed, one needs to be flexible.

B. In a conflict, one should focus on factfinding.

34. A. I evaluate the positives and negatives of the other's argument.

B. If the other's position is important to him/her, I would try to meet those wishes.

35. A. It is more important to be right than to be friendly.

B. I try to help the other feel courage and power to manage his/her own problems.

36. A. I assume that in a conflict we will all be able to come out winners.

B. I assume conflict management is the art of attaining the possible.

37. A. When opposed, I can usually come up with a counter argument.

B. I assume we can work a conflict through.

38. A. I clearly prescribe my goals and expectations.

B. In a conflict, everybody should come out with something though not everything that was expected.

39. A. I prefer to postpone unpleasant situations.

B. I support the other in trying to find his/her way.

40. A. I defend my ideas energetically.

B. I only share that which is helpful to my case.

41. A. I let others know whether my requirements are being met.

B. I try not to hurt the other's feelings. 
42. A. I attempt to define our mutual problems jointly.

B. I sympathize with the other's difficulties, but don't take responsibility for them.

43. A. I put together a logical argument.

B. I express a lot of caring toward the other.

44. A. If it is important, I will put pressure on the other to get what is needed.

B. I join with the other to gather data about our problems.

45. A. I assume relationships are more important than issues.

B. I assume that each of us must give something for the good of the whole. 
Conflict Skills Seminar

Session III

Page 1

Handout $E$

CONFLICT MANAGEMENT STYLES SCORING SHEET

$\begin{array}{llll}\text { Per- Compel Avoid/ Collab- } & \begin{array}{l}\text { Nego- Support } \\ \text { suade } \\ \text { Accom- orate } \\ \text { modate }\end{array} & \text { tiate }\end{array}$

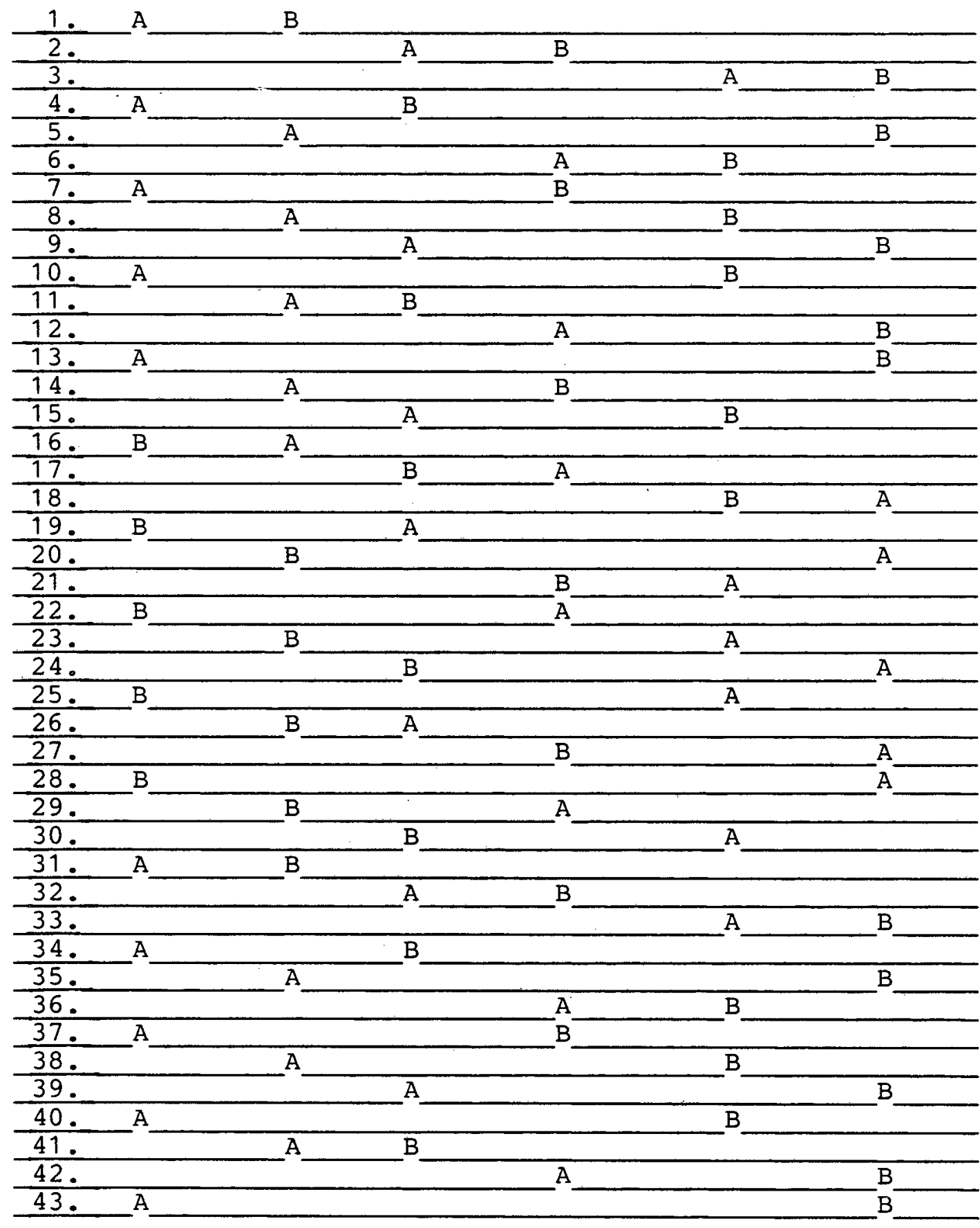


Conflict Skills Seminar

Session III

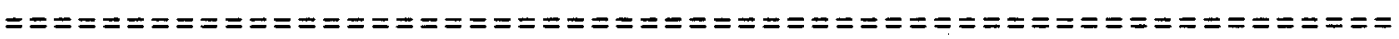
Page 2

Handout $\mathrm{E}$

44. $45.2{ }^{\mathrm{A}}-{ }^{\mathrm{A}}{ }^{\mathrm{B}}-{ }^{\mathrm{B}}-$

Total number of items circled in each column:

\section{Interpreting Your Score:}

None of the conflict managing styles tested by this instrument should be considered "bad" or inferior. A certain style can cause a problem when it is used inappropriately, but one should not assume that avoiding is wrong or that all conflicts must be confronted.

It is possible to get a score from zero to fifteen on each scale in this instrument. The lower your score, the less likely you are to choose this particular strategy or style; the higher your score, the more likely you are to use this style.

The style receiving the highest score will be the style with which you feel most comfortable in the setting you were thinking about when you filled out the form. Of course, the lowest score names the style with which you are least comfortable in this setting. The theory of the instrument is that you are likely to behave more in the modes of your high scores and less in the modes of your low scores.

To interpret your scores, notice the number of differences between each score. If you have a difference of only one between your highest score and your next highest, it will probably be fairly easy for you to choose the second highest strategy as a backup when your first choice seems not to be working. But if the difference is three or more, you will tend to hold on to the strategy with the higher score longer, even when it is not working, because it is significantly preferred over the strategy with the lower score. Those strategies which have very low scores will be very difficult for you to use in the setting on which you were giving yourself feedback. 
Conflict Skills Seminar

Session III

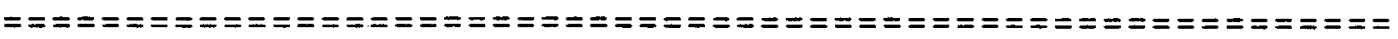
Page 1

Handout $F$

\section{CONFLICT STYLES}

The material that follows was prepared by speed Leas (Discover Your Conflict Management Style). Several conflict management style models have been developed but Leas has the advantage of approaching conflict management from a Christian context. 


\section{Interpreting Your Score}

This instrument identifies six different styles for managing differences: Persuading, Compel I ing, Avoiding/Accommodating, Col laborating, Negotiating, and supporting. Each can be an appropriate style, and none should be thought of as "bad" or inferior. A certain style can cause a problem when it is used inappropriately, but one should not assume that Avoiding is always wrong or that all conflicts must be confronted. Nor should one assume that Compelling is always inappropriate or that one should make an effort in every situation to Collaborate or persuade. In fact, those styles which have been recently touted as always appropriate can be harmful when they are used in contexts which call for other strategies (For example, using collaborative strategies is inappropriate in situations where people will take advantage of naive individuals who may become inappropriately vulnerable. Collaboration is also inappropriate when both sides will not or cannot share all information.)

It is possible for you to get a score of from zero to fifteen on each scale in this instrument. The lower your score, the less Iikely you are to choose this particular strategy or style; the higher your score, the more likely you are to use this style.

The style on which you received the highest score will be the style with which you feel most comfortable in the setting you were thinking about when you filled out the form. of course, the lowest score names the style with which you are least comfortable in this setting. The theory of the instrument is that you are likely to behave more in the modes of your high scores and less in the modes of your low scores.

To interpret your scores, notice the number of differences between each score. If you have a differ- ence of only one between your highest score and your next highest, it will probably be fairly easy for you to choose the second highest strategy as a backup when your first choice seems not to be working. But if the difference is three or more, you will tend to hold on to the strategy with the higher score longer, even when it is not working, because it is significantly preferred over the strategy with the lower score. Those strategies which have very low scores will be very difficult for you to use in the setting on which you were giving yourself feedback. Let's look at some examples. Here is one woman's score:

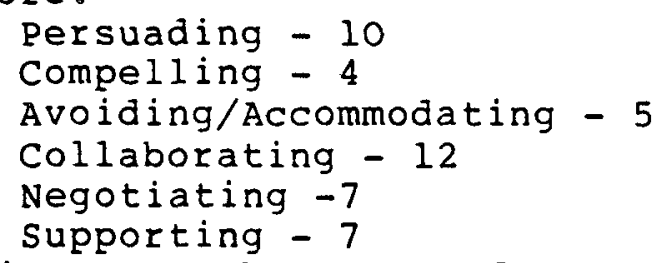

This score shows a preference for collaboration and persuasion in dealing with conflict. The closeness of the two high scores (twelve and ten) means that it will be fairly easy for the person to choose either style, and perhaps use them in conjunction with each other. The difference between the persuasion score (10) and the scores for negotiating (7) and supporting (7), however, is three and this means that it will be difficult for this person to shift into the negotiating or supporting mode if collaboration and persuading don't work. (It will be very difficult indeed for her to use compelling behaviors in the setting she was thinking about.) Let's look at another example: Persuading - 3

Compeliing - 2

Avoiding/Accommodating - 2

Collaborating - 10

Negotiating - 14

Supporting - 14

The scores for this man are different from those for the woman above. Here we have a person who has two 
ores tied for the highest mark. is means that he may have some ternal conflict as to whether to gotiate or support before he will tually be able to enter into the nflict management process. Even ough there is a relatively high ore of ten for collaboration, ere is a difference of four beeen the two highest scores and the cond highest. This person probabwould delay significantly before ing this second strategy. of urse, the extremely low scores for rsuading, compeling and avoidg/accommodating mean that these yles would be virtualiy impossible $r$ him to use. Let's look at one re example:

Persuading - 7

Compelling - 6

Avoiding/Accommodating - 7

Collaborating -9

Negotiating -8

Supporting - 8

ese scores, as you can see, are ry close together, with a total fference between the highest score I and the lowest (6) of three. us, it will not be difficult for is person to use any of the styles the instrument. This person has $\supseteq$ most flexibility of the three amples. The problem with this nd of score is that in those situions which call for a decided il 1 in one area this person may $t$ have enough "stuff" in that ena to perform well. On the other ad, if a wide variety of resources a constantly changing environment needed, this score would be ideal. If you are interested in compai$g$ your scores to the averages of lers who have used this instrument the past, here they are:

Persuading -8.2

Compelling -4.2

Avoiding/Accommodating - 8.1

Collaborating -9.3

Negotiating -7.2

Supporting - 6.3

sse averages represent mostly

ergy and a few lay leaders who have been to workshops with the author of this instrument. For a fuller description of these scores, see the appendix at the end of this booklet.

\section{Choosing a Conflict Management Strategy}

\section{Persuasion}

Persuasion is a style of managing differences that has not been written about much over the past several years; it has been held in disrepute by a number of conflict theorists, especially those--such as Rensis Likert, william Dyer, and Alan Eilley--who tout collaborative approaches to dealing with differences. Nonetheless, it is my perception that persuasjue strategies are

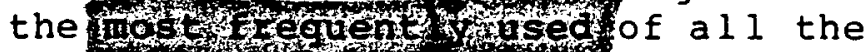
contlict management strategies. (Indeed, they are the most frequently misused strategies,

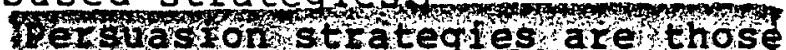
Whel a oerson or groupattemptst

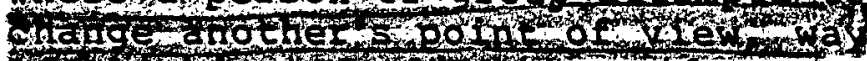

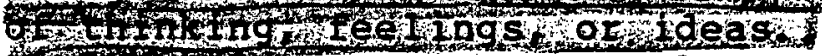
when one attempts to persuade another she uses and

deductive and inductive argument, and any other which she thinks will the other that her opinion is the one which should prevail.

When one chooses to use a persuasixe strategy in conflict, one Wssines that the other is

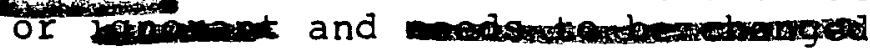
in order to improve the situation, the relationship, the organization or the individual. The persuader does not assume that she needs to change, that she needs to act or think differently. The only one who is expected to change is the target of the persuasive behavior. Thus, persuasive strategies are quite diferent from negotiation or collaboration where it is assumed that all of the parties to the conflict are going to have to share in the change. 


\section{How to Persuade}

There have been many books and articles written on the subject of persuasive argument, especially for debaters and salespersons. Some of the following advice comes from the experience of the writer and some comes from observation of laboratory or field experiments. It is not possible within the 1 imited scope of this instrument to look at a wide range of advice and learning from these sources, but we can skim some of the more important learnings.

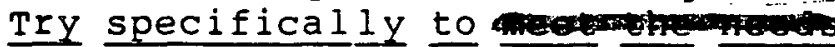
fortan or persons who are the target of your persuasive activities. Many, many scholars have expanded on this truism from Abraham Maslow to Frederick Herzberg, and it is al so recognized by the best conflict management practitioners of our time such as Gerard Nierenberg, Chester Karrass, and Roger Fisher. What they say is that if you want to influence another person, you must know what that person wants, what his interests are. As Fisher and Ury ${ }_{*}$ say in their book Getting tb Yes", "The basic problem in a negotiation lies not in conflict pgsitions, but in the conflict between each side's needs, desires, concerns, and fears"(page 42). They describe a "position" as the individual's or group's conclusion as to how needs can be met. Fisher and Ury define needs as interests. They believe that persuasion is most effective when you understand the problem that the other is facing (the need, or interest) and you respond to that rather than to the position or solution the other is proposing. Responding to the position alone does not help the other perceive that you appreciate what she is up against and it may keep you stuck until you can find a solution (position) that meets both the needs of the other and your own.

*Houghton Mifflin, 1981

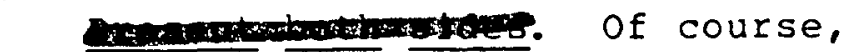
the tendency for all of us in conflict is to downplay or denigrate the position of the other and enhance our own position. This only makes persuasion more difficult. The other resists our arguments because he does not think we understand or appreciate his position. When you move against your own tendency to be. self-protective and one-sided you are inviting the other to respond in $k i n d$. Appreciation goes a long way toward helping persuasion be effective. Recognizing the good points of the other's position is appreciation which is appreciated.

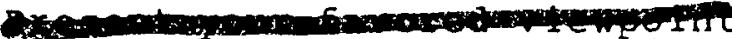
a. people tend to remember and respond to what they heard last. If you put your best argument at the beginning of the discussion, the other will not remember it and will be responding to things that you said later rather than that which you really wanted her to take seriously. Save your best "shot" for the time when it will be best remembered and dealt with.

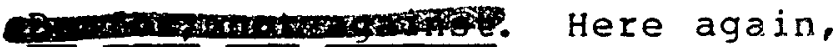
we know that a positive approach is more effective than one which is negative and against which one has to be protected. Those who are best able to persuade are those who are attractive, and negative persons and negative arguments tend not to attract others.

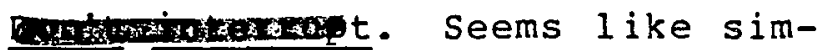
ple and hackneyed advice, yet difficult to practice. Letting the other have his say is another way of appreciating the other and what the other has to say.

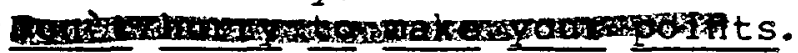
Rushing, pushing, crowding is not persuasive; it is experienced as compeling, and compeling generates resistance to you and your arguments. Taking time, approaching an argument with ease and comfort will generate trust on the part of the other in you and your argument. 


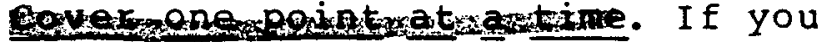
e trying to persuade somebody of mething, she is more likely to be rsuaded one small point at a time an she will be if you try to skip rriedly over the little points at make up the argument for the ole. Build a foundation and step step move toward your goal.

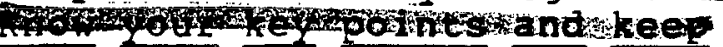

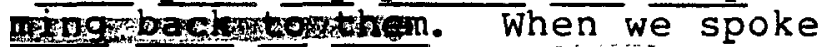
the importance of making your st point last, we recommended this a mnemonic device. Repetition is so effective as an assist to the mory. Even more important than petition and saving your best gument for last, however, is to ow your facts. To be most effecve startby knowing what you are $1 \mathrm{king}$ about--this may not only press those you are trying to rsuade, but it may lower your own nse of inadequacy to the point ere your anxiety will not be teleaphed to the other, corrupting ur ability to persuade.

\section{ien to Persuade}

ile persuasive strategies are tractive to many of us and we are ick to use them, they are often propere, especially Behavioral ience research has been finding at persuasion tends in tow in other rds, as the conflict increases, e trust decreases, and the less kely people are to listen to, let one be persuaded by, what their ponent or enemy has to say.

If you are going to try to change meone else's way of thinking the nditions under which you are most kely to be successful are these: The other is unclear about what e/he wants;

The other trusts your motives; You have prestige and competence the other's eyes;

The other perceives your goals d his/hers to be compatible;
The other perceives herself/ himself to be appreciated or respected by you;

The other does not have strong needs for independence and selfcompetence;

The other does not have strong opinions on the subject.

There are two other conditions that will affect your choice of a persuading strategy: your own willingness to change or compromise in the situation, and whether collaborative or negotiative strategies are available to you.

With regard to your willingness to change, how do you see the problem? Is there any need or reason for you to change your behavior or the way you are thinking about this subject? If you believe that it is unnecessary for you to change and that it is only the other who must do the changing, collaboration or negotiation is not really possible. If you can see the "handwriting on the wall" and don't want to change, but are aware that you must, it is possible to collaborate or negotiate. However, it is not possible to collaborate or negotiate without some willingness on your part to bend or change. If you are not going to bend, then persuasion or compelling or avoiding are about the only choices that you have.

Another way to say this is that you don't see the problem as "your" problem, you think it "belongs" to someone else, and therefore you don't have to modify your behavior or your thinking. When the difficulty that we are experiencing is "ours," then we have the possibility of doing something about it. So the husband who says he is unhappy with the marriage, but is unwilling to do anything to change his own behavior, cannot collaborate or negotiate; he can only attempt to compel or persuade.

The other condition for choosing persuasion strategies we mentioned was whether collaborative or nego- 
tiative strategies are open to you. There are some situations in which it is not possible to negotiate or collaborate, even when you are willing to change your own behavior or thinking: such as when it is not possible for you to be fully open with another person (this would preclude collaboration, but not negotiation), when you or the other parties involved don't have sufficient skill tolerance or experience at collaboration to be able to use this mode, or when repeated and significant attempts have been made to collaborate or negotiate and these have failed. In these circumstances you may have to turn to persuasion or compelling as your inly alternative strategies.

\section{Probable Outcomes of Persuasion Strategies}

Persuasion strategies can be ingenene often, when we hope that we can convince others of doing things that are "for their own good". and/or for the good of the organization, they and while they are with us, but when they are not in sur presence. Much has been written about power in organizations and relationships and people are continuously clamoring to find ways to nake people do things without actually compeling them. This is the problem with persuasion. We hope that the other will comply, but argument without authority often seems weak and inadequate in the Eace of those who have the power and right to overricie our recommenaations when they choose.

Further, it is precisely when trust is low and resistance is high that we wish we could influence another person through persuasion. sut these are the situations in which persuasion is least likely to se effective. What's the alternative? It is mon-

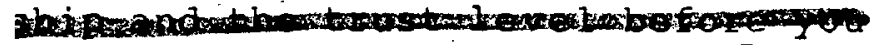

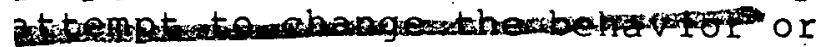

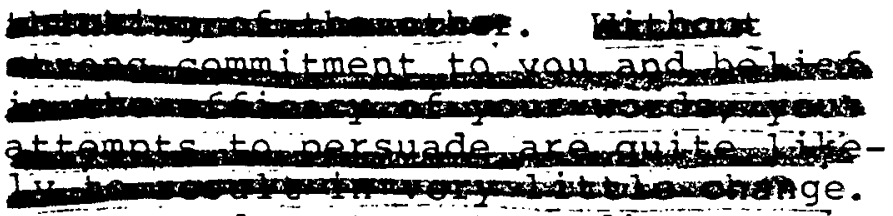

So we do not want to discount persuasion as an effective conflict management tool--but it is more likely to be effective with people on your side than it is with the opposition (especially in high con$f(i c t)$, and $i t$ will not be useful until significant work has been done in relationship building.

\section{Compelling or Forcing}

I define compelling as the use of ity or or oblige or constrain another to do something that another group or person wants done. (Notice that here I did not say or imply that you can compel a person to think a certain way. I don't believe that is possible. People

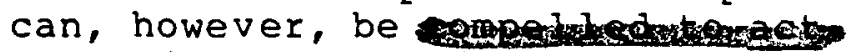
according to the wishes of those with the most physical force.)

Most of the compeling that we experience in our day-to-day 1 ives is not compelling through the use of physical force but that which comes through the use of authortey Authority is the right that we give to a person or group to make certain decisions for us -- because it is expedient or because we can't agree. Authority comes through a tacit or explicit contract we make with others. For example, when people join an organization they discover it has an explicit contract (constitution or bylaws) by which the members are expected to abide. This contract sets forth the rules of the game by which people will play and authorizes certain groups or individuals to make certain decisions for the rest of the group: i.e., the president names the nominating committee, the treasurer prepares the first trial budget for the following year, and so on. There are also many 
cit contracts in an organization relationship: "we've always done that way" is one, social mutual derstandings of roles, like those mothers and fathers, are another. thority is the understanding that have of who is responsible for at, and we let people exercise rtain influence within the bounds of at understanding. of course, when person steps beyond the bounds of at mutually understood authority, cit or explicit, his or her auority ceases and the ability to mpel or force is nil.

What are some examples of compe1ng using explicit authority?

A policewoman pulling a motorist the curb and giving her a ticket. A pastor explaining to a couple at he will not marry them because does not think they are yet mare enough to understand or carry $t$ a long-term mutual commitment. A doctor admitting a patient to e hospital.

An arbiter telling each side what will get out of a particular ttlement.

What are some examples of the use tacit authority?

A parent telling a child to pick his room.

A consultant telling the members

a group to be quiet so they can

ar one another.

A stockbroker telling a person in ich stock to invest.

The question that comes before alst every person in a conflict tuation is, "Is it or to use comIling strategies?" And the answer that question (as to most quesons in life) is, "It all depends." have learned a great deal about a impact of compeling behaviors others, and we know that if they $\geqslant$ used consistently over a long riod of time people suffer, relaonships deteriorate, individuals se their spontaneity, manipulative ravior develops, and rebellions ? likely. But there are times en compeliling behavior is needed and/or wanted within an organization or within a relationship. These will be discussed below. The point to make here is that compelling is like the use of certain drugs: in short-term emergencies sometimes not only is it called for, but nothing else will work. In the long term compeling is caustic and rots out relationships and organizations.

\section{How to Compel or Force}

/To increase your success_at_compelling behavior, your both tacit and explicit.; As we al 1 know, it can be to the advantage of an influencer of policy to have the rules changed so that she or he is given the right to make more decisions in the organization. But your authority can also be enhanced by your youre about a particular subject (hence you become an authority), by imengeng your

and and by and the size of the which is favorable to your point of view. Audiences are a significant force in organizational dynamics. To the extent one perceives that he or she is under the scrutiny of either numbers of people or certain individuals particularly respected by the rest of the organization, one is likely to act in ways designed to please these individuals or this audience. Thus a way to increase your power in the organization is to get those who are already authorities there to agree with you

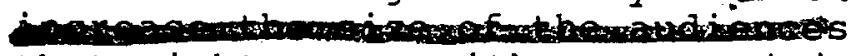
drat micht acrea with your positiong" of course, the simererey are about what it is that you want-your goals, your standards, your values, your expectations--the greater your ability to compel others will be. Nothing will vitiate your ability to influence others more than your own unclarity about what it is that should be done. To the extent that you can keep control of the conversation and keep 
the wingan the argument, you $f$ increase the chances of your compel1 ing behavior having an impact. To the extent that you lose the initiative, you will be put more on the defensive and find that more of your energies go to protecting yourself rather than getting the change that you want in others. You will find that compelling behavior also seems to stick better when you end the conversation when it is finished, rather than going back over ground that has al ready been covered or attempting to move into "softer" modes such as persuading. Responses to authoritative behavior seem to be more effective with a compelling style. To the extent that the compeller also tries to tone down or sweeten the style, s/he is likely to diminish the compulsive power.

(Note well that "compulsive power" is not long 1 ived nor does it have much effect when the authority is not present. So, to the extent that you push this behavior you are likely to diminish later self-generated behavior on the part of the individual or group you are trying to influence.)

of course, the compel ler will need to be about what $\chi$ the are, if what is being "requested" is not complied

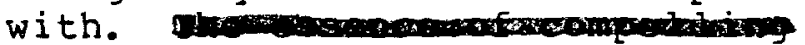

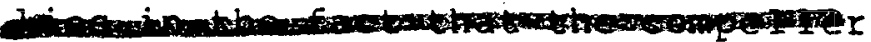

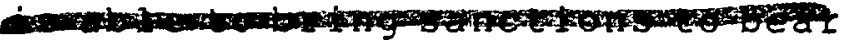

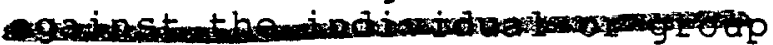

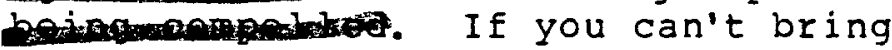
sanctions, you are not literally compelling the other. Some people threaten consequences which they could theoretically bring to pass, but it is known that the threats are empty. This also is not compelling behavior. It will have little, if any, impact on others if they don't believe you can or will implement your threats.

If you want your threats to have meaning in the future you will want to be sure that you whoms to bear immediately upon non-compli- ance with your demands. This will show that when you say something, your are not just mouthing words, but you will follow through on your statements -- thus your words are more likely to be believed and to have more tacit authority.

Compeling behavior is further

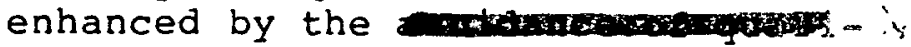
wom such as "I hope," "I wish," "perhaps," "wouldn't it be a good idea if...." "in my opinion." These phrases take the punch out of the more direct, authoritative statement that lets the other know where you are coming from and demands a clear response. The rule here is: a clear statement will get a clear response (not always what you want, but at least you'll know where you stand).

Just because you think you are clear doesn't always mean that you are clear, so it will always be a good idea to check to see whether of not you have been understood. Check to see that the other understands you by requesting some kind of statement that will indicate to you that he knows how to comply.

\section{When to Use Compelling}

intreguerty. Because of the probFin's that come with regular use of this strategy, you will find that it is not only more effective, but people will respond better when these strategies are used sparingly.

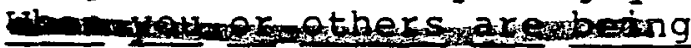

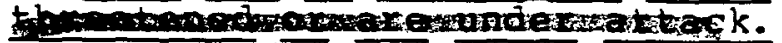
course, this is the time tocall sush stitategies into play--under emergency conditions. Assuming that these conditions won't last long, you respond with appropriate authority and force in order to protect what is being threatened.

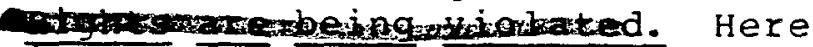
again, we are talking about threat and attack. In situations of injustice, when other means have failed, it is appropriate to increase the level of pressure to a point where 


\section{Avoid/Ignore/Accommodate/Flee}

Under this third category I have included four distinct conflict management styles or strategies. I could have developed this instrument in a way that would have separated these four styles. We would then have ended up with nine categories of conflict strategies. This would have required us to remember too many categories ( $\mathrm{six}$ is almost too much as it is) and answer too many questions--108--more than twice as many). In order to avoid these problems I combined these four categories defined as follows under the heading "Avoid/Accommodate."

\section{Hordande}

When one avoids conflict, one exdes it or stays away from it. one attempts to skirt it or keep it from happening. Putting a tricky agenda item late in the meeting in hopes that you won't get to it, not bringing up an uncomfortable subject, attempting to keep people who might bring up "the" subject from speaking--all are avoiding.

\section{Igroing}

Throling a conflict is acting as if it weren't going on. Most people aren't able to do this very well, but it is possible. In an organization, sometimes the leaders are able to ignore conflict by never putting the issues on the agenda of the organization and only talking about "it" before or after the meetings.

\section{atering}

Frioring (above) is the only passive strategy for dealing with conflict. Avoidance takes effort and attention to what is happening so it won't be Jealt with and so does fleeing. Eleeing is actively removing yourself from the arena in which conflict might take place. As a conflict management strategy fleeing an occur before or during a conflict, but if it occurs after the conflict has taken place, it would be a result of conflict not a conflict strategy.

\section{Hecostunodat on}

This is another active strategy. When one accommodates, one goes along with the other, with the oppom sition. A person who is using an accommodative style often believes

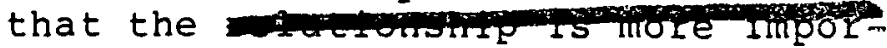
tont thanthomeses and will therefore shrink from any confrontation that might be required to deal with the issue in order not to jeopardize the relationship. Often it will take some self-control to suppress the feelings that arise when one is not able to get what he wants because he chooses to go along with what the other wants. Another word for accommodation could be "giving in." (Avoidance, ignoring, and fleeing are also kinds of "giving in" in that they allow the status quo ante to stand rather than changing the situation in any way.)

\section{How to Avoid, Ignore, Accommodate or Flee}

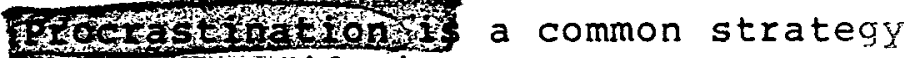
used to avoid, ignore or accommodate. Putting off dealing with the confict may be the most common way that people utilize this set of strategies.

Another common way of implementing these strategies is to $\mathrm{sa}$ destrito every request that is made

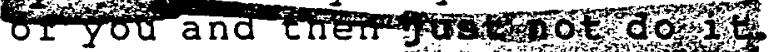
Note that this i ganotherily accommodation, though it seems so on the surface. Accommodation means actually going through with what the other wants you to do. Saying one thing and doing another is ignoring. Another kind of ignoring strategy

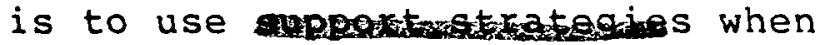
you should be using collaboration, negotiation, compelling or persuading. We'll discuss support strategies a little later, but at this point suffice it to say that paraphrasing and showing concern for the 
elings of the other, without reunding to the problem, is in fact loring or avoiding the problem-you are a part of the problem or fully or partly responsible for $\checkmark$ it gets dealt with.

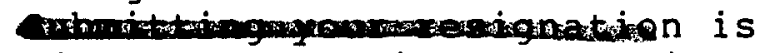
eeing. Threatening to submit your ;ignation unless you get your way compe 11 ing. And, of course, a time honored oidance strategy for governments lorganizations is to atadyatwo boluem with no intention of doing thing about it.

\section{en to Use Avoidance, Ignoring, :ommodating, or Fleeing Strategies}

i le the manner in which I have scribed the avoidance/accommodaon strategies above tends not to respectful of their use, there $\geq$ many occasions when it is indeed eful and appropriate to employ em.

Sometimes the cost of actualiy tempting to work a problem through greater than the value of having eked it through. In those cases ese strategies would be the right oice.

When individuals within the orization or relationship are parzularly fragile and insecure, you l choose not to work certain ises because doing so would cause j much damage.

When people need time or "space" cool down, avoidance is sometimes propriate.

When there is conflict on many onts, you may want to avoid cerin areas of conflict in order to vote your energy to others.

When the differences are trivial irrelevant to your relationship the organization, they are often st avoided.

When the parties in a conflict a unable or unwilling to reconcile 2ir differences or attempt to work em through and they must continue be in the same place or to work together, avoidance, ignoring, and/ or accommodating are the only

choices available.

When you don't care about the relationship and the quality of interaction within it avoidance or fleeing is appropriate.

When you are powerless to affect change of any kind, when the other does not or will not respond and repeated efforts have been made to invite the other to address the issues with you and try to work them through, then fleeing (leaving) is the only choice. Notice here that the key word is "powerless." Don't underestimate your power and the resources available to you with the result that you too quickly bail out of a relationship that could be salvaged.

\section{Probable Outcomes}

The most serious problem with this cluster of conflict strategies is

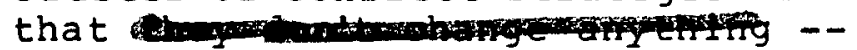
usually hov don'tamen when one chooses to avolid, accommodate, flee, or ignore, and und they are: what is unjust remains unjust, what is unfair remains unfair, and what is disrespectful remains disrespectful.

We believe that people we respect can stand up to and grow from a loving confrontation. Avoiding says, "I have given up on you and the relationship at this point. I don't think it, you, I can improve or change. Thus, the element of disrespect.

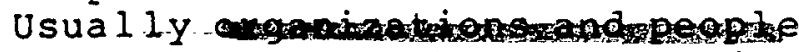

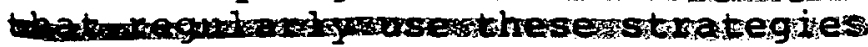
-redereasedrandemandepressed

The people don't feel good about themselves and use much of their energy restraining themselves.

\section{Collaboration}

Collaborative conflict strategies are frequently touted as the best or only strategy to use when dealing 
with conflict. As I have indicated above, it is only the best strategy in those situations that appropriately call for its use.

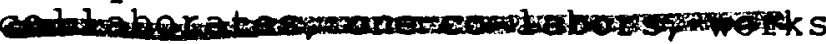

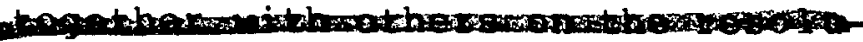

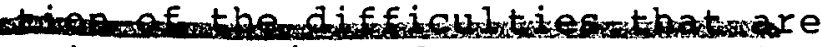
armanged In a conflict situation collaboration means that you work together with the people with whom you disagree. You might

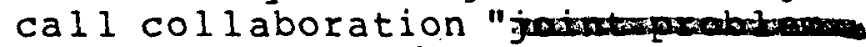
er "mutual problem solving," because that is the essence of what a collaborative strategy is.

\section{How to Collaborate}

When one is using a collaborative approach to dealing with conflict the following steps must be carried out by all parties to the conflict. Where any step is taken without the involvement of the others in the conflict setting, it must be repeated with the others in order for it to be truly collaborative.

- jointly acknowledge that there is

a problem;

- jointly agree on ground rules;

- jointly agree on process for dealing with the problem;

- jointly define the problem(s);

- jointly identify shared interests;

- jointly invent options for mutual

gain;

- jointly agree on criteria for

choosing among the options;

- jointly choose an option or

options.

Frost and wilmont give an example of how to collaborate in their book Interpersonal Conflict ${ }^{*}$ :

"A married couple have conflict about their priorities. For the wife, the husband works too much and does not spend enough time with her. Eor the husband, the wife is not

\footnotetext{
${ }^{\star}$ P. 30 (Will iam C. Brown Dubuque, IA 1978).
}

interested enough in his work. A simple lowering of his working hours and spending more time with the wife and an increase of her interest would be one possible way to manage the conflict. But if the two parties collaborate, they work together on the conflict to identify the underlying concerns of both parties. It may be for example, that both of them want more warmth and affection in the relationship and the conflict arose because each one's way of attempting to get affection was not working. Through such collaborative effort, they explore the disagreement in order to learn from one another's insights. They may discover, for instance, that the time of day for taking time together makes a big difference. They may be able to meet for lunch occasionaly $y$ and then the husband can work at home late on an evening. Collaboration as a style means that one person asserts individual goals while being concerned with the goals of the other also."

\section{When to Use Collaboration}

The time to choose collaborative strategies is in those situations where you and the others involved

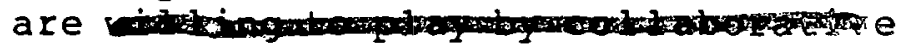

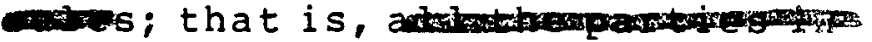

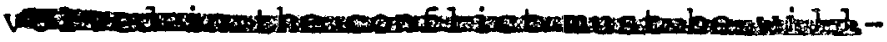

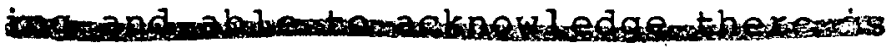

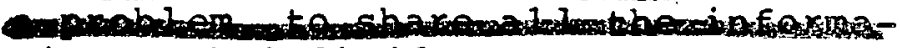
tian each individual or grouts bass

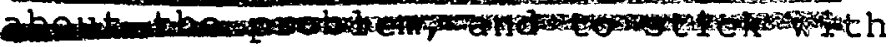

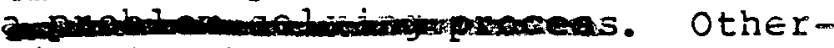
wise it will not be possible for one individual or one group or some individuals or some groups to "collaborate" while the others are doing something else. All the parties must be able to enter into this mode.

Al 1 of the parties must be willing and able to come to sessions where the issues will be discussea. And there must be a good deal of motivation on each group's part to 
ick with the problem solving prois once it is under way. This

Il take stick-to-itiveness on the :t of everybody concerned, because often seems easier to move out of ? collaboration and on to quicker id what seem in the short run to be re satisfying) modes to use, perasion and compelling:

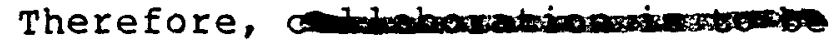

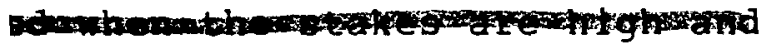

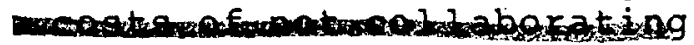

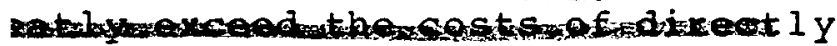

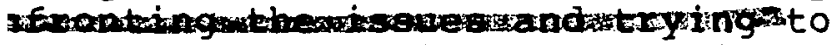

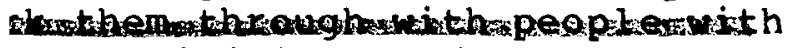

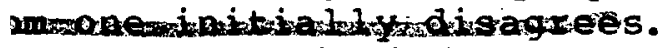
Not only do individual predilecsns interfere with a group's abil, to collaborate, but also the ims or unwritten rules of the lanization sometimes conspire inst collaboration. Often the up is well trained to believe lert's Rules is the only recourse n the going gets rough, and these es assume persuasion and compelig as the major means of dealing h difference. To overcome these ms (and sometimes written poli$s$ about how to proceed in conct) may be a formidable chalge in itself.

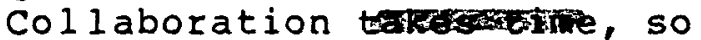
re has to be enough time availe to use this method.

Sometimes, also, the issue will ect whether or not it is possible

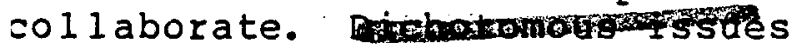
sues where only two choices ex, such as whether to fire a Ef person) cannot be worked coloratively. Rather the issue must zhanged to one which will allow laboration: for example, "How this staff person's performance improved?"

iurther, gonflimeverabimated jurces, where the resources are lequate to meet fully every per$s$ or group's needs, cannot be .t with collaboratively. These is of conflicts will require

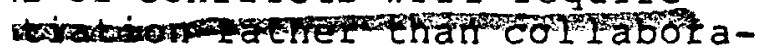

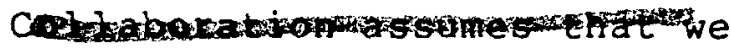

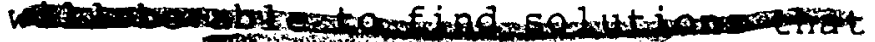

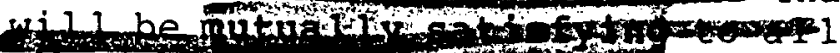
thenarties, which as weal l know is not always possible.

Finaliy it needs to be recognized that collaboration is probably not going to be possible in waymo

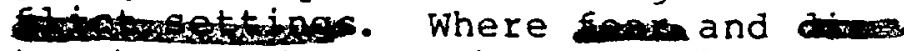
arare at exceptionally high levels, these emotions are likely to cloud people's ability to share fully with one another and genuinely engage in a joint problem solving process.

\section{Likely Outcomes of Collaboration}

The reason why behavioral scientists and others who study conflict are so keen on collaborative strategies is that the likelihood of real success is greatly increased when people are able to join in mutual problem solving:

- People will have high motivation to comply with their joint decisions.

- The quality of decisions is usually significantly increased.

- People's problem-solving abilities are usually strengthened.

- All the parties to the original conflict usually walk away from it with a sense of satisfaction and success: "We did it!"

\section{Bargaining or Negotiation}

We can use the words "bargain" and "negotiate" interchangeably; they mean virtually the same thing. Muray

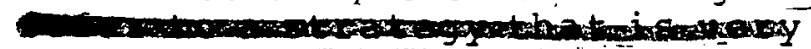

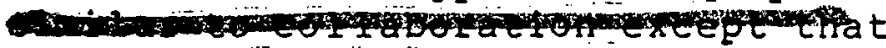

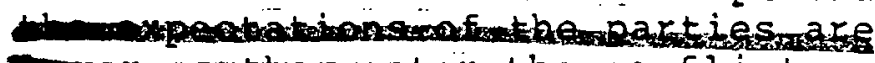

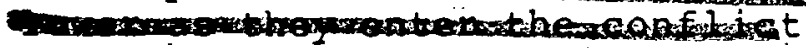
arena: Instead of seeking solutions which are mutually fulfilling to both parties or all of the groups, persons who use negotiation will be trying to get as much as they can, assuming that they will not get everything they want but at least they will get some of what they 
want, as the others get some of what they want. In other words, where collaboration is a "win/win" strategy, negotiation is a "sorta-win/ sorta-lose strategy.

\section{How to Bargain}

Bargaining is the At it is a process of matas

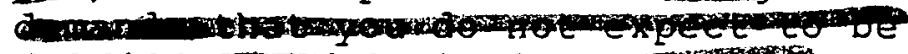

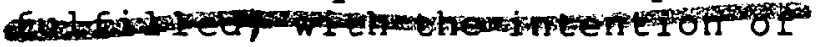
G6x

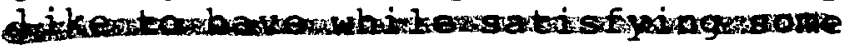

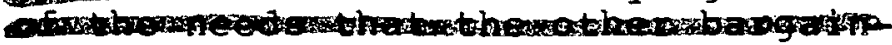

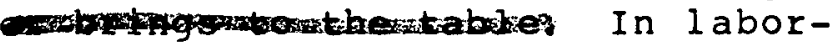
management negotiations "good faith" bargaining is often defined by whether or not a party has shown "progress" in the negotiations through willingness to back off from some of the original demands. If a party has not reduced the original demand or demands in some way, the other side or persons who are monitoring the process may call "foul" because of the unwilingness of one of the parties to reduce the original demands.

Because of this need to prepare to settle for less at the beginning of the bargaining process, some bargainers may start with outlandish demands in order to end up with a satisfactory settlement. of course, when this is taken to an extreme the other bargainers find this behavior offensive and they not only have diminished trust, but sometimes become quite hostile. This makes bargaining even more difficult.

In order to do a sood job of bargaining, there must be sme mared and mamaton between the parties involved. You will recall that in our discussion of collaboration we indicated that the parties must share all the information that each has; in other words, there must not be secret or privileged information withheld from the other party. When we are bargaining this is not the case. We do not expect the other side to share everything, nor do we share everything; we share only that which we think will be helpful to our case. This reluctance to share reduces trust between the parties, but it is understood as one of the givens of this style of conflict management--and because it is expected, the withholding of information is not $1 \mathrm{ikely}$ to be as harmful. to the process as it would be in a situation where the parties assume that the other will be open and fully disclose everything relevant to the case.

Many experts propose that the negotiators start with the cumber there are a number of problems to be resolved. Starting with things we can agree on can help us to generate some optimism about our ability to work things through, and it can help us be less defensive.

Effective bargainers also find they are helped by a process in

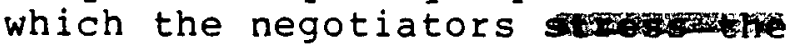

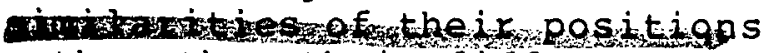
rather than their differences. In order to reach agreement the parties will have to believe that agreement is possible and well within the realm of reasonable and responsible action. To the extent that the bargainers are not optimistic about this fact, they are likely to reduce their efforts to look for solutions that incorporate some payoffs for a 11 sides.

Bargainers are also helped by

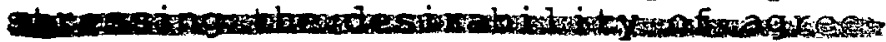
When you are in a conflict with another person and that indi$v i d u a l$ doesn't seem to be entering into the conversation in a way that leads you to believe you will be able to find agreement, you may become discouraged and begin to believe the whole business is hopeless. It is from such a despairing stance that belligerent and hardline positions are likely to escalate rather than reduce the tensions. The more you can let the other know you really want agreement 
It is not possible for one side to bargain alone. All the parties must come to the table and join in the give and take.

We find that bargaining is not a good idea in those situations where there is a great power disparity between the parties (unless that power disparity is compensated in some way). What may officially be designated as bargaining does not feel like bargaining when one of the parties perceives that they must go along with the proposals suggested by the other (This is not bargaining; it is compelling.)

Finally, we know that bargaining is not a good strategy to use when the level of fear and perceptual distortion about the other and the situation is high in one or more of the parties. This is a condition in which negotiation is not impossible, but in which it is best postponed until all sides feel a modicum of safety and each is able to approach the problems somewhat rationally and with a clear head.

\section{Probable Outcomes}

The outcomes of negotiated conflict management are similar to those for collaboration, except that the commitment to the decisions is not quite as strong. The solutions that people come up with seem to suffice, but they don't fully satisfy. Sometimes with negotiated agreements the parties have to be reminded of their agreements after they have been made. On other occasions, because of the lessened commitment to the decisions, the parties may look for chances to revise the decision since they didn't get everything they wanted out of the original decisions.

\section{Support}

Many people have learned support strategies through training in the helping professions. Often these strategies are called exmmuivatwan major a the major assumption of this strategy is that owsond on

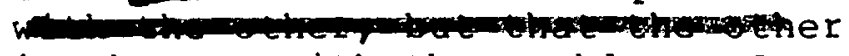

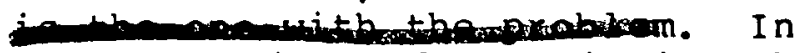
collaboration and negotiation the major assumption is that the parties share responsibility for "fixing" the difficulty. Not so with support. Here the assumption is that

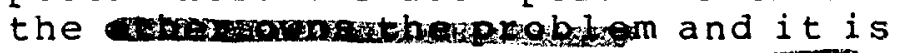

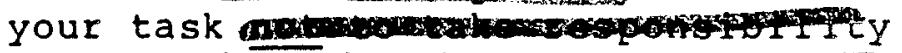

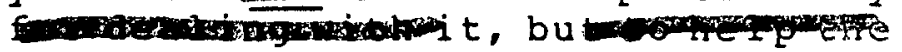

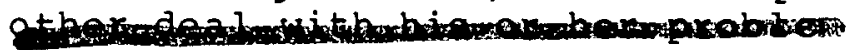

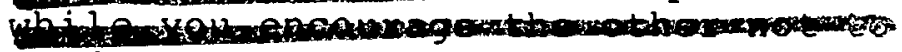

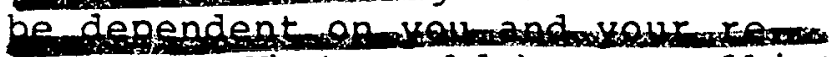
solurges. What would be a conflict situation where this kind of strategy would be appropriate? Where two parties are in conflict with one another and one or both are trying to get you to take a side. If one of the parties complains about the behavior of the other, then it is not your problem -- but you can be helpful to one or the other by trying to help them function in a healthy and ethical manner toward the other.

Perhaps another way to define this strategy is to call it a

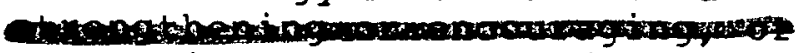

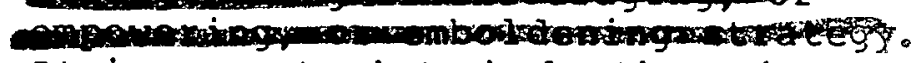

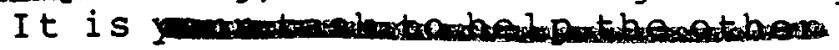

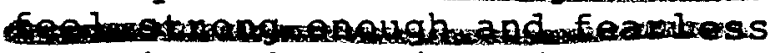

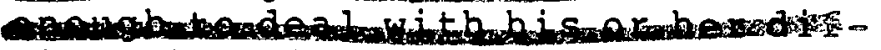

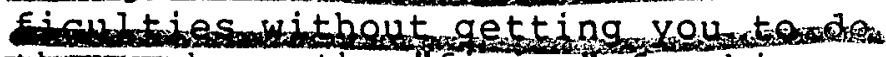

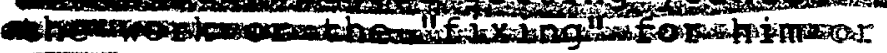
Fier.

\section{How to Support}

When a person is under stress, it is important to give him or her an immediate opportunity to expend some of his or her energy. We can relieve some of the stress by encouraging the other to express or describe the feelings being experienced. This means that we encourage him or her to talk, to be angry, or to cry. It will help if you ...make short, neutral statements 
questions that acknowledge the her's feelings;

...reflect the feeling content of person's words or actions.

ually this will reduce the feelys temporarily, allow the other to ok at the situation a little more jectively, and facilitate more Eective problem-solving.

Moreover, support can be enhanced helping the individual to explore əther other issues are bothering $\geq$ person in addition to the "preating problem." Sometimes a small zident will trigger an unexpectedstrong reaction, and it becomes portant to check the possibility tt something else is bothering the sson, beyond what has been exəssed. Frustrations may have been ilding up for some time, perhaps Ly now being expressed. Without zouragement, a person may still be sitant to discuss the real sources his or her frustration.

If we want to find out the real urce of a person's stress, it is portant to ask neutral, open-ended istions that stimulate the other talk. If we ask specific or saded" questions, we may never get the source. In this phase it is so important to communicate an :eptance of what the person is ing. If we judge him or make him II ashamed of his condition, we I 1 compound the problem. If it is possible to do so, with ? support strategy one should tempt to help the other adapt to ? situation being encountered. ptation can take place in differ: ways: taking action to change ? self or the environment or oth$;$, or by redefining the situation. is means that we help the other by , loring the situation with him or : and look for ways that changes lht be forthcoming. We can sugit alternative modes of action and $L p$ the other come up with new as for how to deal with the situon.

(The above material has been modi- fied from stress in Community Groups, by Jerry Robinson, Roy Clifford, and Joke Dewalle, University of Illinois, 1975.)

Mostly, however, support strategies help the other to feel confident and strong that he or she can deal with what is out there. Here you function primarily as a cheering section prodding the other to act and to deal with the situation. To the extent that you try to admonish, judge, warn, order or bargain with the other, you are likely to hinder your efforts at supporting -- because these strategies essentially require your motivation rather than the other person's to get the needed change and action.

\section{When to Support}

The critical issue in choosing support strategies has to do with "whose problem is it" with which we are going to deal. If it is not your problem, that is, it is not your responsibility to deal with it, or you do not want the responsibility for dealing with it, and it is the responsibility of the other person to do something about it, then a supportstrategy would be in order. For example, if someone came to you (from a neighborhood distant from yours) complaining of neighbors who are noisy at all hours of the night, that is not your problem to solve. What you want to do is to help your friend deal with the issue in the best way possible. You want to strengthen and encourage your friend to do what needs to be done in that particular setting.

It is also appropriate to use support strategies when the other person is bringing to your relationship troubles and dissatisfactions outside of your relationship with him or her. For example, your spouse may come home from work annoyed at the events at the office that day. Perhaps she is angry and 
TWO DIMENSIONAL MODEL OF CONFLICT BEHAVIOR ${ }^{1}$

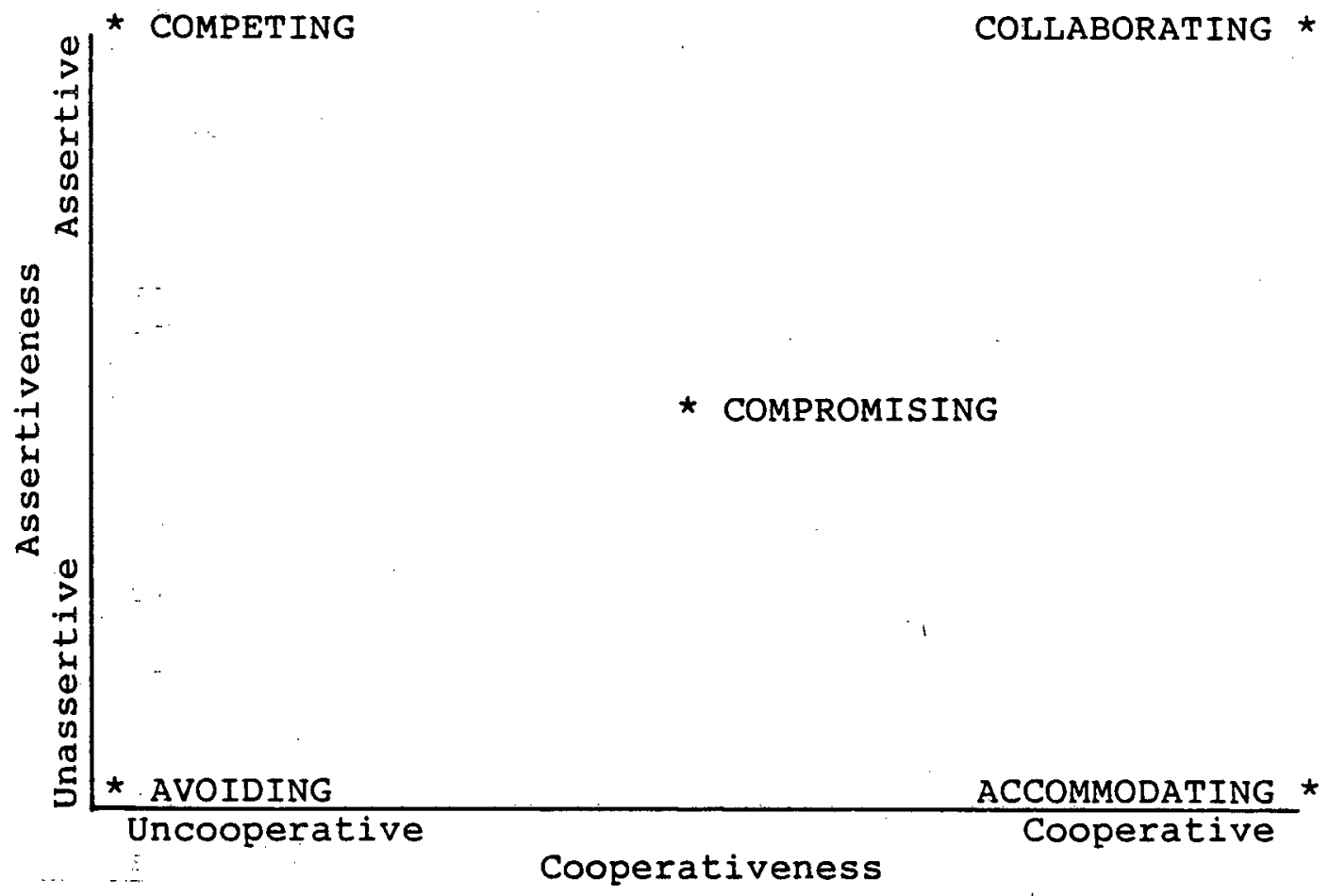

${ }^{1}$ Richard A. Cosier and Thomas L. Ruble, "Research on Conflict-Handling Behavior: An Experimental Approach," Academy of Management Journal 24 (December 1981): 817. 
SMALL GROUP PRACTICE OF THE MANAGEMENT STYLES

\section{Directions:}

Read the background statement below.

Do not discuss the background statement specifically with the rest of your committee.

Do not specifically discuss the style of management that you as a group should take to solve the issue because likely, you would not do this in a reallife committee.

You are to role play your part on the committee. If you are among the two older committee members, then you are in favor of the status quo. If you are among the two younger committee members, then you are in favor of the innovation. Your committee must either come to a decision on this matter this evening or it must set up the mechanism to resolve the problem.

\section{Background:}

You are a committee commissioned to redecorate the church sanctuary. Early in your work, a conflict developed in your committee over whether to replace the pews with movable seating and to extend the podium into the seating area. Your committee is evenly split on the subject--the younger members favor the innovation and the older members opt for the status quo. Though there has been some discussion among the members of the congregation over the possibility of change, so far the members of your committee feel more strongly about the issue than the rest of the church. Though you would like to see your way prevail, you are not anxious that the is sue divide the church. You feel, however, that if the committee was able to make a unanimous decision either way the membership would likely go along. 


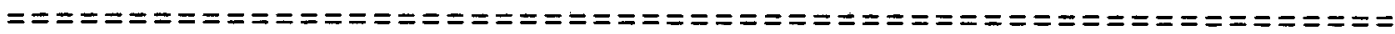

Handout $\mathrm{H}$

SMALL GROUP PRACTICE OF THE MANAGEMENT STYLES

Directions:

Read the background statement below.

Do not discuss the background statement specifically with the rest of your committee.

Do not specifically discuss the style of management that you as a group should take to solve the issue because likely, you would not do this in a reallife committee.

You are to role play your part on the committee. If you are among the two older committee members, then you are in favor of the status quo. If you are among the two younger committee members, then you are in favor of the innovation. Your committee must either come to a decision on this matter this evening or it must set up the mechanism to resolve the problem.

Background:

You are a committee commissioned to redecorate the church sanctuary. Early in your work, a conflict developed in your committee over whether to replace the pews with movable seating and to extend the podium into the seating area. Your committee is evenly split on the subject--the younger members favor the innovation and the older members opt for the status quo. There has been a great deal of discussion among the members of the congregation over the possibility of change and some feel as you do. Though you haven't stated it publicaly you feel so strongly about the change that if it doesn't go your, way you will transfer to another church. You are hoping that the committee will delay a decision rather than make the wrong one. 
SMALL GROUP PRACTICE OF THE MANAGEMENT STYLES

Directions:

Read the background statement below.

Do not discuss the background statement specificalIy with the rest of your committee.

Do not specifically discuss the style of managment that you as a group should take to solve the issue because likely, you would not do this in a reallife committee.

You are to role play your part on the committee. If you are among the two older committee members, then you are in favor of the status quo. If you are among the two younger committee members, then you are in favor of the innovation. Your committee must either come to a decision on this matter this evening or it must set up the mechanism to resolve the problem.

\section{Background:}

You are a committee commissioned to redecorate the church sanctuary. Early in your work, a conflict developed in your committee over whether to replace the pews with movable seating and to extend the podium into the seating area. Your committee is evenly split on the subject--the younger members favor the innovation and the older members opt for the status quo. Though there has been some discussion among the members of the congregation over the possibility of change, your not aware of any deepseated feeling either way. You are aware, however, that a member on your committee has said privately that he would transfer his/her membership if the committee voted the wrong way. You, personally, can't see why chairs should be such an important issue. 
SMALL GROUP PRACTICE OF THE MANAGEMENT STYLES

Directions:

Read the background statement below.

Do not discuss the background statement specifically with the rest of your committee.

Do not specifically discuss the style of managment that you as a group should take to solve the issue because likely, you would not do this in a reallife committee.

You are to role play your part on the committee. If you are among the two older committee members, then you are in favor of the status quo. If you are among the two younger committee members, then you are in favor of the innovation. Your committee must either come to a decision on this matter this evening or it must set up the mechanism to resolve the problem.

Background:

You are a committee commissioned to redecorate the church sanctuary. Early in your work, a conflict developed in your committee over whether to replace the pews with movable seating and to extend the podium into the seating area. Your committee is evenly split on the subject--the younger members favor the innovation and the older members opt. for the status quo. There has been some discussion among the members of the congregation over the possibility of change, and a few of you have studied Ellen white on the subject. You are now convinced that she supports your viewpoint. Since you certainly don't want the church to sin, you have determined to stand your ground. 


\section{PERSONAL CONFLICT EVALUATION}

Directions: Select a conflict that you experienced or witnessed during the last week. Answer the questions in the space provided.

1. Briefly describe the conflict.

2. Relate the portion of conversation that indicates what type of conflict was experienced.

3. What style of conflict management did each participant use in the conflict?

4. What would you do differently next time? 


$$
\begin{aligned}
& \text { "FROM WIN-LOSE TO WIN-WIN" } \\
& \text { OUTLINE }
\end{aligned}
$$

I. Pre-session

Handout A--"Outline"

II. Reflection on the "Personal Conflict Evaluation" sheets (10 minutes)

Handout B--"Summary of The Conflict Management Styles"

A reflection exercise using Handout I ("Personal Conflict Evaluation") from Session III.

III. Biblical concepts (15 minutes)

Handout C--"Biblical Values"

Biblical values dictate how we look upon those with whom we disagree.

IV. The use of power in conflict ( 27 minutes)

Handout D--"Negative Use of Power"

Handout E--"Power Building"

Handout F--"Conflict Gaming"

A discussion of the costs of the use of power to resolve conflict and the possible alternatives.

V. Listening Skills (20 minutes)

Handout G--"Communication Gap"

Handout H--"Two Listening Skills: Paraphrase, Perception Check"

A discussion of two skills that facilitate communication.

VI. Small group practice $(15$ minutes)

Handout I--"Listening Skills Practice"

Small group practice of the skills learned.

VII. Homework assignment ( 3 minutes)

Handout J--"Reading: 'Group Conflict May Promote Positive Solutions'"

Handout K--"Listening Skills Exercise"

An at home exercise to in the use of the listening skills. 
SUMMARY OF THE CONFLICT MANAGEMENT STYLES

I. Persuade

A. Strengths

Works best in lower levels of conflict when there are higher levels of trust.

often faster than other methods.

works best if you have prestige, authority, or are respected.

B. Weaknesses

A person may give you verbal assent but not follow through.

without strong commitment to you, there is little change.

II. Compelling or Forcing

A. Strengths

Fastest method of getting a desired response.

Best method for an important, unpopular course of action.

only practical if you have authority and can bring sanctions to bear.

Best method if under attack or threatened by an outside source.

B. Weaknesses

Should be used infrequently.

Reduces morale.

Those compelled will seek means of increasing their power and independence.

Causes loss of self-respect.

Friendships often threatened.

Outward compliance often achieved at the expense of inward cooperation.

III. Avoid

A. Strengths

Possible to avoid problems that are not your own, or stay away from problem situations you know you can't handle. 
= = = = = = = = = = = = = = = = = = = = = = = = = = = = = = = = = = = = = = = = = = = = = = Page 2

No risk involved.

No confrontation.

B. Weaknesses

You allow others to make a decision for you; no willingness to get involved.

Loss of self-respect; may resent lack of involvement.

Breeds conceit: "I'm not the cause of the trouble."

Avoiding does not change anything.

IV. Accommodation

A. Strengths

You may feel a measure of success because relationships are maintained.

You may feel good about self; may feel Christlike, although this can be a misconception.

B. Weaknesses

Loss of self-respect, especially if you give up something you really believe in.

others can lose respect for you; tends to set patterns that allow others to walk over you.

V. Collaborate

A. Strengths

People work together to settle conflict by arriving at a mutually acceptable solution. Works best when the stakes are high and the costs of not collaborating greatly exceed the costs of directly confronting the issues and trying to work them through.

B. Weaknesses

Takes time.

Does not work unless there is trust and openness.

Does not work if the conflict does not allow for a middle ground solution. 
Conflict Skills Seminar

Session IV

= = = = = = = = = = = = = = = = = = = = = = = = = = = = = = = = = = = = = = = = = = = =

Page 3

Handout $B$

VI. Negotiate (Compromise)

A. Strength

Engenders a feeling of maturity.

Maintains relationships; allows people to keep self-respect.

Helps people find new solutions that did not previously present themselves.

Lowers expectations.

B. Weaknesses

You may feel uneasy if some aspect of the solution violates what you believe you should stand for.

Conflict can become a game--a battle of wits.

Does not work when the conflict does not allow for a middle ground solution.

Takes time.

VII. Support

A. Strength

The other person feels you are sympathetic.

You are not committed to a course of action.

You remain aloof from the conflict.

Engenders good feelings.

B. Weaknesses

Does not lead to a solution.

Ultimately, the other person may feel disappointment when you do not become involved. 


\section{BIBLICAL VALUES}

Read the following verses and be prepared to discuss what light they shed on how a Christian ought to view a person with whom he is in conflict.

"You. have heard that it was said, 'You shall love your neighbor and hate your enemy.' But I say to you, love (agape = love, respect, not necessarily a feeling but revealed in actions) your enemies and pray for those who persecute you, so that you may be sons of your Father who is in heaven; for he makes his sun rise on the evil and on the good, and sends rain on the just and on the unjust. For if you love those who love you, what reward have you? Do not, even the tax collectors do the same? And if you salute only your brethren, what more are you doing than others? Do not even the Gentiles do the same? You, therefore, must be perfect, as your heavenly Father is perfect (teleios = whole, complete, mature)." Matt $5: 43-48$ (RSV).

"It is actually reported that there is immorality among you, and of a kind that is not found even among pagans; for a man is living with his father's wife. And you are arrogant! Ought you not rather to mourn? Let him who has done this be removed from among you. For though absent in body I am present in spirit, and as if present, I have already pronounced judgment in the name of the Lord Jesus on the man who has done such a thing. When you are assembled, and my spirit is present, with the power of our Lord Jesus, you are to deliver this man to Satan for the destruction of the flesh, that his spirit may be saved in the day of the Lord Jesus." 1 Cor 5:1-5 (RSV). 


\section{NEGATIVE USE OF POWER}

Conflict is intimately related to power. It is often a source of conflict, and it is often used in an attempt to resolve or manage conflict. As a general appraisal, one theorist wrote, "Power inevitably begets conflict, in some form and in some degree." 1 For instance, the manner and degree in which conflict is expressed depends on the reciprocal power of the person who is the target of the initial change attempt; the target of change may use his/her power to resist attempts to change his/her behavior. Alternatively, if his/her own power is great enough, he/she may "counter" with an attempt to change the other person.

Examples:

A parent compels the child to clean up its room. The child pushes the mess under the bed.

Or, the child "punishes" the parent by throwing a tantrum.

The pastor compels the elders into a visitation program.

The elders vote as a block to defeat the pastor's cherished program on board.

Or, the elders get too busy to make their visits.

Power may be defined as A's ability to modify the behavior of $B$ in $A$ 's desired direction without altering his/her own behavior.

Power bases include:

Reward

Coercion .

Referent

Legitimate

${ }^{1}$ Robert Kahn and Elise Boulding, eds., Power and Conflict in Organizations (London: Tavistock, 1964), pp. 1-7, quoted in George F. Weiland and Robert A. Ullrich, Organizations: Behavior, Design, and Change (Homewood, Il 1.: Richard D. Irwin, 1976, p. 226 . 
Conflict Skills Seminar

Session IV

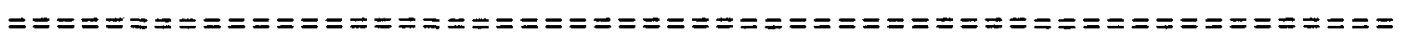

Page 2

Handout $D$

Expert

Informational

Examples of what can be the negative use of power that are often used in a church setting:

majority vote to settle a conflict
limiting discussion on a controversial issue
preaching on unity
using the nomination committee to remove opposition
from the board
using procedural technicalities to defeat opposi-
tion

The use of power (compelling and forcing) may result in short term success but over the long run problems usually develop.

Morale will be lower in an organization that continually uses power to settle conflict.

Those who are compelled will:

seek means of increasing their own power,

seek for ways of being independent from those who exercise power.

will find ways of revenge through sabotage, noncooperation, nongiving, etc.

Frustration and disappointment with those who use power unfairly causes heightened emotions (such as anger, hatred, bitterness) that results in public and private outbursts and other irrational behavior.

In effect, the negative use of power increases the likelihood that interpersonal relationships will be damaged. 


\section{POWER BUILDING}

Power building is using your power for the purpose of building up the power of your opponent.

People and groups that perceive that they have a balance of power tend to fight fair and reach mutually acceptable solutions more readily.

Ways of power building:

Referent

Legitimate

Expert

Informational

Further suggestions:

Never patronize.

Use open body language.

Use listening skills.

Consult the other for the purpose of learning the strengths of the other's point of view.

Compliment sincerely.

Engage the other in the process of problem solving. If a subcommittee is formed, see that the other is on the committee.

Encourage openness by being open.

Discuss the issue and how you feel about the issue and encourage the other to be frank about his/her feelings.

Remember, the other person's opinion though different from yours is a resource.

Examples:

To wife: "You know, honey, I respect your opinions. I know that we differ on this one, but I am anxious to know your thinking. Tell me, about your plan?"

To a child who wishes for an extra privilege you would prefer not granting for several years: "I feel that you are a very responsible young man/lady. The fact that you have made this suggestion indicates to me that you have given this 


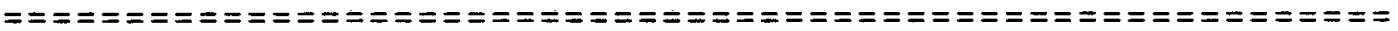

a great deal of thought. How have you decided that you would handle this new responsibility?"

To a fellow church board member with whom you disagree on a sensitive issue: "Jim, your position makes a lot of sense. I am especially impressed with your point that... I doubt that we can come to a satisfactory solution on this matter tonight. However. I think that I would like to work with you. I believe that by putting our heads together we can find an acceptable solution." 

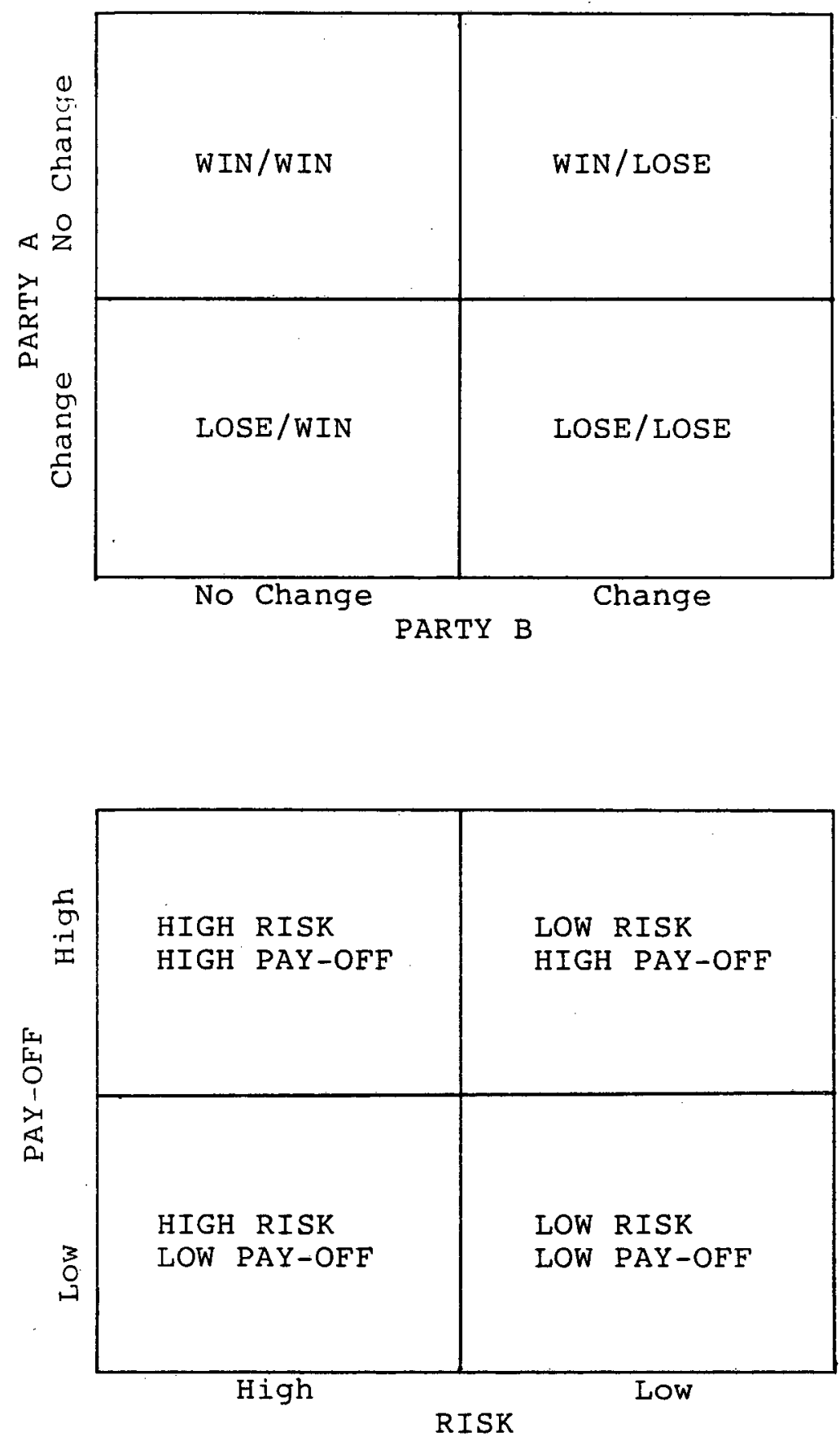


\section{COMMUNICATION GAP}

I. Lag Time

The average rate of speaking is 100-150 words per minute.

The average rate of listening is 400-500 words per minute.

The difference between the rate of speaking and the rate of listening is called "lag time".

Lag time can be use constructively or destructively.

The purpose of this training is to provide you with listening skills that will help you to use lag time productively.

II. Congruence in Communication

Communication components:

Words $-7 \%$

Tone--38\%

Body language--55\%

When all give the same message there is congruence. Examples of incongruence:

III. Four Stages in Developing Listening Skills
A. Information
B. Awkard
C. Intentional
D. Integrated 
Conflict Skills Seminar

Session IV

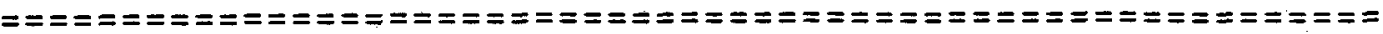

Page 2

Handout $G$

IV. Communication Cycle

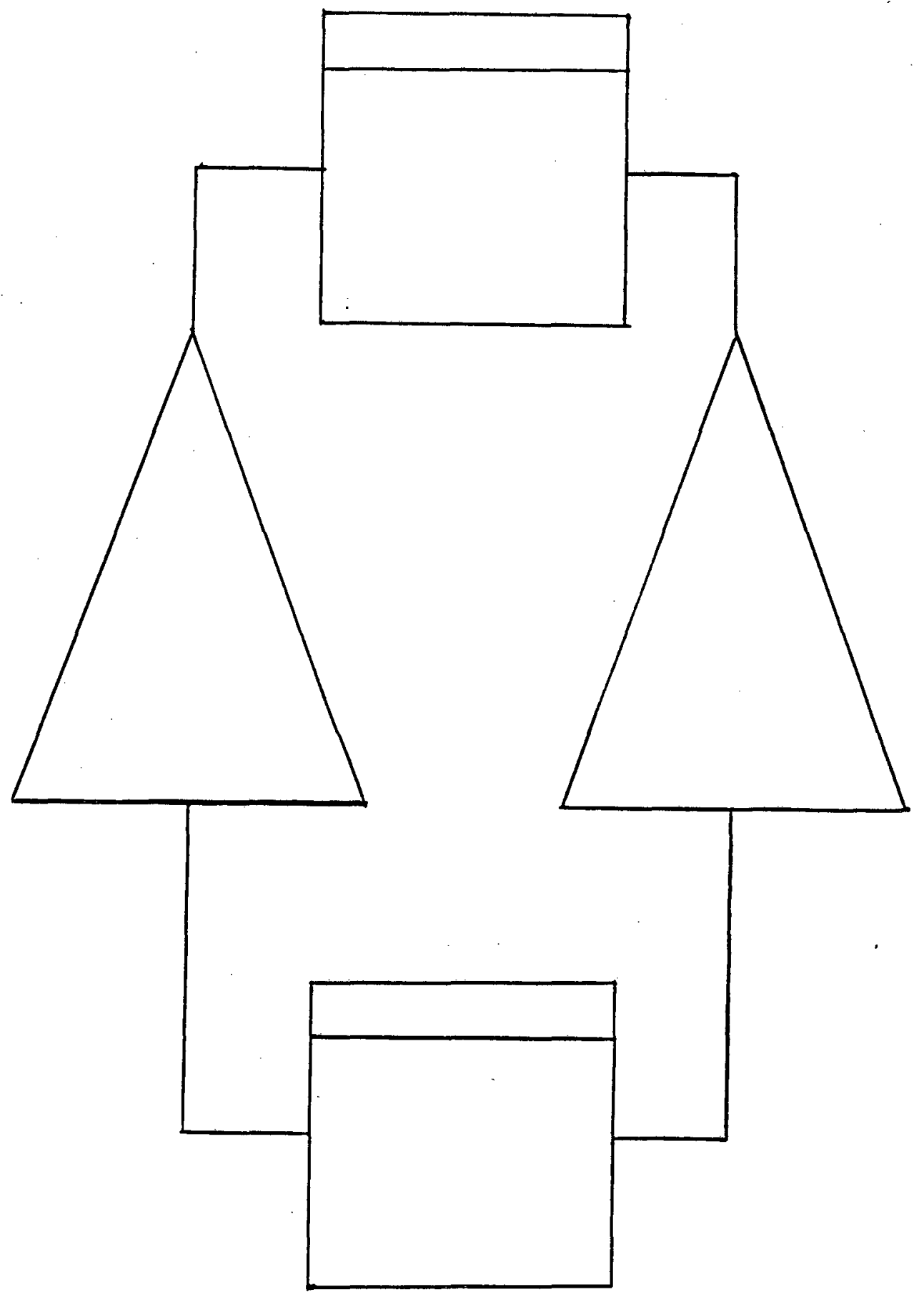


Conflict Skills Seminar

Session IV

= = = = = = = = = = = = = = = = = = = = = = = = = = = = = = = = = = = = = = = = = = = = =

Page 1

Handout $\mathrm{H}$

\section{TWO LISTENING SKILLS: \\ PARAPHRASE, PERCEPTION $\mathrm{CHECK}^{1}$}

During the next four sessions, we will be learning and practicing a number of valuable skills that will help you maintain positive interpersonal relationships even though you may be engaged in conflict.

\section{Paraphrasing}

Pharaphrasing is the skill of responding to the content and meaning of another's verbal communication.

The purpose of pharaphrasing is to let the other person know that you have heard him/her, to make sure that you understand what the other is intending to say, and to let the other know that you are interested in what he/she may be saying. It is not probing or psyching out the other. Rather, it is letting the other know what his/her statements mean to you. It deals primarily with the content of what the other is saying--facts, ideas, questions, and so forth.

Example:

A committee member says, "I tried a half dozen times to get Tom to accept my idea, but every time I try he cuts me off."

Paraphrase checking content for accuracy: "You're saying that after trying many times to share with Tom, he cuts you off."

Pharaphrase checking meaning of inference: "Do you mean that Tom doesn't care about what you say?"

Use these:

"Do you mean . . ?"

"Is this... (statement) an accurate understanding of your ideas?"

${ }^{1}$ Adapted from Kenneth. J. Mitchell and John $S$.

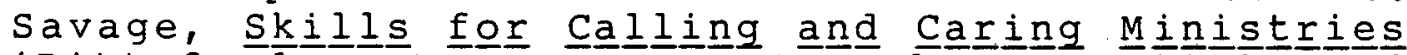
(Pittsford, N.Y.: L.E.A.D. Consultants, 1979) and Lawrence $M$. Brammer The Helping Relationship 3 rd ed. (Englewood Cliffs, N.J.: Prentice-HaIl, 1973). 
". . is that correct?"

"If I hear you correctly, you're saying . . ? ?"

"What I hear you saying is . . ."

"Do you mean...?"

\section{Perception Check}

Whereas, paraphrasing is primarily concerned with verbal communication, perception checking seeks to identify the the other's feelings.

You describe what you perceive the other is feeling in order to see if you understand correctly. You transform the other person's nonverbal expressions of feeling (gestures, expressions, tone of voice) into a tentative, nonjudgmental description of feelings. A good perception check conveys the message, "I want to understand your feelings. Does this describe the way you feel?" Use a neutral tone of voice.

Examples:

Tom: "I have worked with Fred for six years now and I still can't get to first base with him. He's a hard nut to crack. Nothing seems to please him."

Bill: "It sounds to me as if your experience over the years with Fred has made you feel the situation is hopeless. Am I right?"

Tom: "Yes, you're right. I have tried so hard to get along with him but nothing works. He is so critical and demanding!"

Bill: "Tom, I'm wondering if you're not feeling a lot of discouragement at this time. Would I be right?"

Use These:

"I get the impression that. . ."

"I'm wondering if...."

"It seems to me that... ."

"It sounds to me if...."

"I have a hunch that...."

"It appears to me that... . ."

"Is it possible that you might be feeling . . ?"

"I sense that we might have caused you to feel..."

"I have feeling that you're experiencing...." 


\section{LISTENING SKILLS PRACTICE}

This is a ROUND. ROBIN practice of the active listening skills--paraphrase and perception check.

Divide into groups of three. There are three rounds of 5 minutes each in this activity. In each round, one of the three will be the "speaker", the "listener", and the "observer".

Speaker: Talk about what you heard in the presentation, "The Communication Gap." What are the important points that remind you of the problems that you face?

Listener: Your task is to be helpful to the speaker in thinking through what was said in the presentation. Listen actively to what the speaker is saying. Particularly work at paraphrasing what is said to make sure you understand. Also, see if you can detect any inner feelings that can be identified by a perception check.

Observer: Watch listener for use of the skills of paraphrasing and perception checking. Make notes of the behaviors you see and hear. You will share your observations with the listener in order to help him/her improve his/her listening skills.

Format of each round:

Three minutes: speaker shares

Listener actively listens

observer is silent and takes notes

Two minutes: Observer shares observations

All three discuss listener's behavior

Rotate for next round: speaker becomes listener listener becomes observer observer becomes speaker

Repeat the round robin three times. 


\section{READING: "GROUP CONFLICT \\ MAY PROMOTE POSITIVE SOLUTIONS"}

Read the article written by Delbert Fisher titled "Group Conflict May Promote Positive Solutions" (Ethicon, 1985). Be prepared to discuss at our next meeting some of the key concepts of this article.

1. According to the article, what are some of the results of viewing conflict as destructive?

2. What are the reasons for encouraging debate?

3. What guidelines does the author suggests are necessary in order to have constructive conflict?

4. What method of conflict management does the author favor? 


\title{
roup Conflict May Promote ssitive Solutions
}

\author{
I W. Fisher, Ed.D. \\ ate Chief of Staft for Education \\ ins Administration Medical Center \\ oose, Als.
}
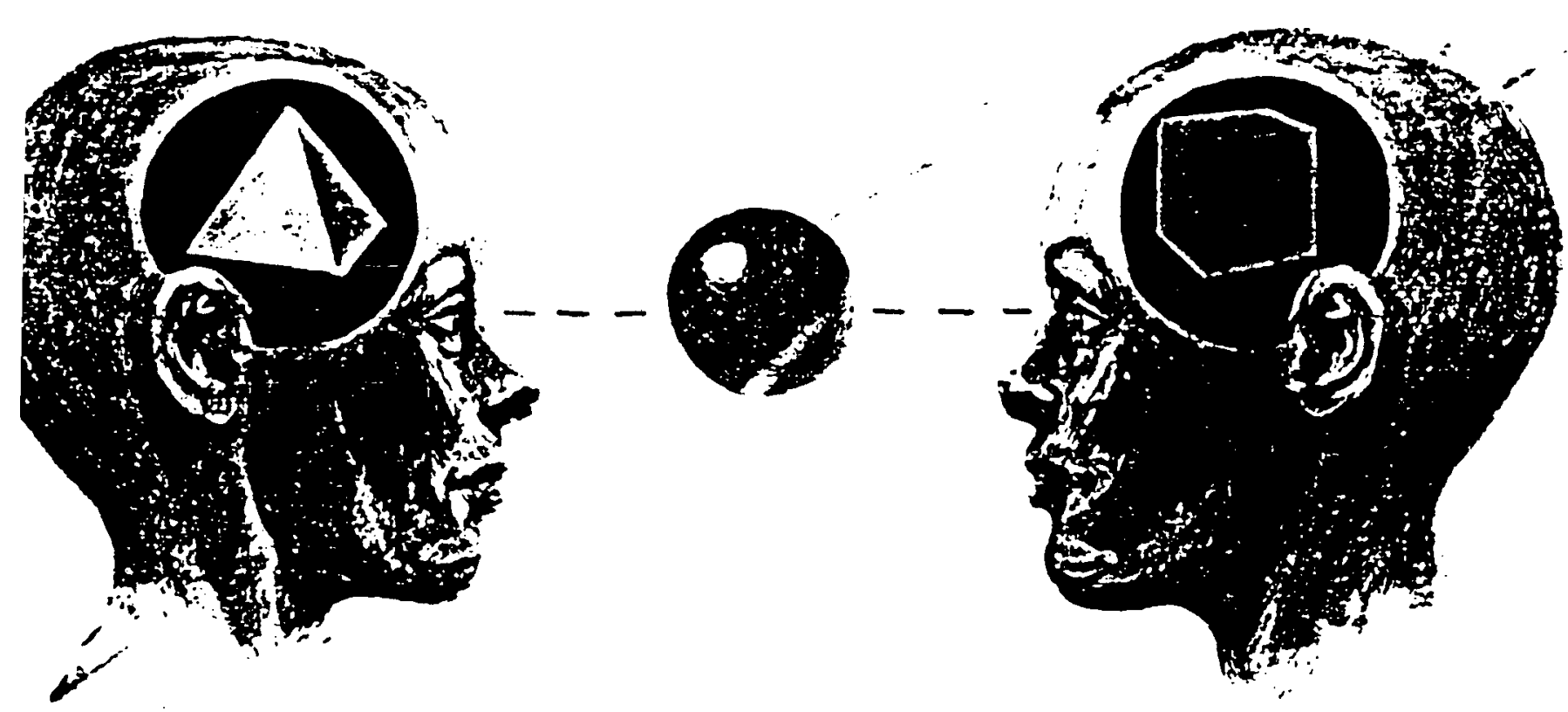

3usc people have different points of 4. Connict in the work situation is inable. Although contlist is a normal romenon. some staff members may erience frustration in accepling conas a positive torce in effective decimaking. For some people, conflict ites a state of ambivalence which must eetlled by suppressing the conflict at cost. For them nice people don't fight. - cannol accepl conflict as a nermal ess. And they have even greater diffi$y$ in appreciating the fact that when ady managed confict is a dynamic $e$ in reaching a consensus on a shared dem.

When conflict is viewed as destructive, ren phenomena develop within the f. Members with a low tolerance for nict become passive. For these people, solution is better than the present e of conlict. Members with a greater rance for conflict become competiltive. se members divide the staf into wins and losers. And they want to be ners

Both reactions to conflic indicate that staff-members do not have a team it. The members cannot integrate their fideas inte a common goal. Settling the issue or winning becomes more important than searching for the best solution for the geatesi number of people.

When conflict is perceived as destruc. live. the behavior of the members reinforces this climate. Members develop defense mechanisms; they begin to withdraw. become spectators or project blame onio others. Members quickly become locked in to their point of view. Each has difuculty finding the good in the ideas presented by others. It is even possible for members to become aggressive and resort to personal attack, rather than focus their disagreement on the issues. The best solutien to common problems generally is found by reviewing different points of view about the issue. When a staff can tolerate argumentation, a climate exists that supports a rigorous review of the evidence and a thorough discussion of alternate courses of action. When these actions are supported, chances for making wise and effective decisions are greater.

There are at least three reasons for encouraging the statf members to debate for their point of view:

1. When members present their points of view, all gain a broader view of the problem and its implications. When different viewpoints are encouraged, the total staff becomes beller infarmed about the problem. This broad understanding is important in helping the members appreciate what the real problem is. The real problem may not be what started the discussion, but it can be more readily detected in debate.

2. When free discussion about the problem is encouraged, the staff has more alternatives from which to select a solution. Peter Drucker. who has srudied decision making in organizations. concludes that only in disaereement are alternatives developed. 1 Without discussion, a staff may prematurely commit to a solution or apree with the only solution that was allowed to surface. Both of these allernatives lend themselves winoffeetive deeisionaking.

3. Strong discussion has the potential for involving the members in a participative manner in searchine for a solution to a mutual problem. When a good discussion is going on. members are less like y lo be passive or thinking about their next activity. They are more ac- 
tively listening and assisting with a positive attifude.

A climate that allows free and open discussion has the potential for bringing out creativity. A fres and open climate changes the atmosphere to an exciting adventure in which each person's skills and talents are used in a common goal.

\section{Constructive Criticism}

Argumentation becomes constructive conflict only when it is effectively managed. Constructive criticism requires a good teamleader and a tew guidelines:

1. Staff members must be open and straightforward. Suggestion of criticism without follow through does not and the situation.

2. Staff members must be aware of their biases and not let them interfere with real listening. When a member is thinking. "What can you expect from a doctor. nurse, administrator, etc.," not much real listening is taking place.

3. Criticism must be of the proposal and not the individual. A critical remark directed at an individual is usually perceived as a personal attack. A critical remark directed at a proposal has a better chance of being accepted.

4. The word you makes remarks personal. Instead of, saying. "You missed the point," substitute. "The point in this proposal is ..." This is more helpful.

5. Words such as all, more, always, never and invariablv are absolutes. They are easily refuted and may close the door in the seanch for alienatives.

Nithough few will admit it. seldom do people come to work with a desire to be negative. We seek to be interested and use our skills. Disagreements arise because of a sincere involvement with the problem from a particular point of view.

Through work and good leadership. staff members will ciscover they can be open. Thus their ideas do receive support and fair trealment. They then become commilted to working for aconsensus on a common problem. This should result in pride in accomplishments and a commiment to work tor implementation of solutions and a sense of satistaction in belonging to the staft.

\section{Negative Conflict Resolution}

Conflict or disagreement is an integral part of life. The question about conflict is not whether or nol if exists, but rather how is it manaced? - negatively or positively?

One negative way of managing conflict is to deny it: simply refuse to acknowledge that it exists. Similar to denial is the effor to smooth it over. "We run a happy ship." Both of these negative approaches are ineffective. Conflict dots hot go away; it onty submerges. Different points of view are discussed outside a staff meeting or after a decision is made.

Power or authority also has the potential for being a negative way to settle conflict. Power can be vested in a person or in a position. If a particular person or the leader makes all the decisions. the other staff members may feel helpless in bringing about real improvemerit.

Power car atso be'present in conflict reducing strategies. such as voting. When this strategy is used. usually there is an underlying assumption that discussion never really settles anything, so let's vote. Voting may work in a general election but in a work unit it can divide people in to winners and losers. Future interactions are influenced by the memory of how previous contlict was resolved.

Bargaining is also a conflict reducing strategy. Bargaining means people give a little on this issue, and then collect some points on the next issue. In certain situatons bargaining is necessary. But as a regular tool in solving problems. it generally creates more problems than il solves. Members lose the focus of the hospital or depariment, and are more concerned in winning a few concessions for their own area, without regard for the overall
benefits.

\section{Positive Problem Solving}

Effective problem solving is dependent upon a review of varying points of view in an open and trusting climate. Disagreement is the best vehicle for broadening perspectives discovering aliematives and stimulating creative interaction. The effects of disagreement depend on how $h$ is managed. When mismanaged. conflict can destroy effectiveness. When managed well. it can greatly increase the quality of work. make people proud of their depar. ment. and improve the decision making effectiveness of the staff.

Training in the nature of conflict and methods of managing it is a pressing need in many hospitals. There is a need to dispel the negative associations of conflict and replace them with positive concepts When staff members realize that conflict can be a creative force in discussion, they are better prepared to adopt effective personal attitudes and behavior in staff meetings.

\section{References}

1. Drucker PF: Menagement: Teske Responsubilitues. Practices. New York: Harper and Row. 1973

2. Simpson OT: Manding group and organization con fict. The 1970 Annual Handbook for Group Facth. tators. Luvolla. Ca: Jones. Pfertier. 1979

3. Ward JT: Constructive conflict in discussions Learning to manage disagreement effectively. The 1070 Handbook for Group Facilitalors. Lajolla Ca: Jones. Pfeitter. 1979

4. Weiss 8: Constructing your eriticism. Supervinosy Management 26 (5). May 1981
Delbert $W$. Fisher is coordinator of education and training at the Veterans Administration Medica Center, Tuscaloosa. Ala. He holds an EdD degree in adult education from Indiana Universion He has spent his career in varrous phases of human relations including teaching. counseing and administering 


\section{LISTENING SKILLS EXERCISE}

Directions: Select a conflict that you experienced or witnessed during the last week. Answer the questions in the space provided.

1. Briefly describe the conflict.

2. What type of conflict? (Facts, or values.)

3. What management styles were used by the participants? (Persuade, compel, avoid, accommodate, collaborate, negotiate, or support.)

4. Write down the portion of conversation that demonstrates the use of paraphrasing and perception checking. 
= = = = = = = = = = = = = = = = = = = = = = = = = = = = = = = = = = = = = = = = = = =

\section{DEALING WITH EMOTION IN CONFLICT}

OUTLINE

I. Pre-session

Handout A--"Outline"

II. Feedback on the homework assignment (27 minutes)

A. Feedback on Handout J ("Group Conflict May Promote Positive Solutions") from Session IV.

A. Practice of the listening skills--paraphrase, perception check--using Handout $K$ ("Listen Skills Exercise") from Session IV.

III. Theory of anger (30 minutes)

Handout B--"Theory of Anger"

Handout C--"Methods of Handling Conflict"

A discussion of the theory of anger for the purpose of learning how to handle anger in one's self and in others.

IV. Listening skills (10 minutes)

Handout D--"Two Listening Skills: 'I Feel'

Statements, Fogging"

A discussion of two skills that facilitates communication.

V. Small group practice (20 minutes)

Handout E--"Listening Skills Practice"

Small group practice of the skills learned.

VI. Home work assignment ( 3 minutes)

Handout F--"Reading: 'Anger and Your Temperament"" Handout G--"Listening Skills Exercise"

Handout $\mathrm{H}--$ "Anger Inventory"

An at home exercise to develop an understanding of anger within the temperament environment and to develop the use of the listening skill called fogging. 
Conflict Skills Seminar

Session V

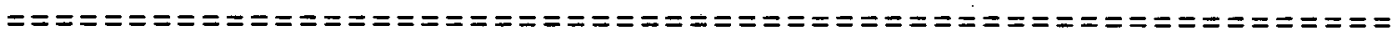
Page 1

Handout $B$

\section{THEORY OF ANGER ${ }^{1}$}

The traditional dualism of religious piety tended to split feelings, attitudes, and emotions into two categories labeled "good" and "bad." Warm and gentle emotions--love, kindness, patience--were classified as good. The cold emotions, such as hate, or the hot emotions, like anger, were categorized as bad. Spiritual development was understood as a process of eradicating the bad emotions and cultivating the good.

This position, however, ignores the fact that anger has other functions than to smash, hurt, spoil and destroy. For instance, anger can be useful in establishing values, correcting injustice, and promoting growth. A person without anger cares about little, cannot love, and is not likely to experience supreme joy.

Description:

"Anger is an emotion. It arises when a wish or a desire is not fulfilled. When a desire is not fulfilled, we feel an urge to change that situation or to destroy it. Anger, then, is an urge to attack somebody or some thing for the purpose of altering or destroying it. Or, anger can be deflected away from the primary object of anger and displaced onto a substitute object. This happens when the primary object of anger is too powerful or too necessary in our lives to risk attacking it.

"Anything that prevents us from gaining what we want is called a frustration. We say our goals or desires are frustrated when they cannot be obtained. Frustration is the event, and the emotional response to frustration is what we call anger. Technically the expression 'I feel frustrated' is inaccurate. We can BE frustrated, but the emotion we usually feel when frustrated is anger or hostility."2

${ }^{1}$ Norman Rohrer and S. Phillip Sutherland, Facing Anger (Minneapolis: Augsburg, 1981); Tim LaHaye and Bob Phillips Anger is a Choice (Grand Rapids: Zondervan, 1982 ).

${ }^{2}$ Rohrer and sutherland, p. 8-9. 
Conflict Skills Seminar

Session $\mathrm{V}$

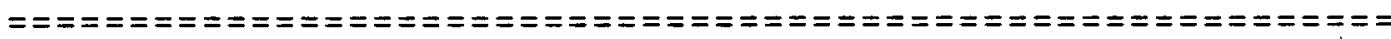

Page 2

Handout B

Sources of anger:

1. The desire to feel powerful.

2. The desire to feel self-sufficient.

3. The desire to feel important.

4. The desire to be perfect.

How to handle anger in others:

1. Determine the source of the anger.

2. Remain separated from angry people's emotions.

3. Don't accept blame.

4. Determine what their anger is covering up.

5. Refuse to be a "garbage dump."

6. Don't augment their fantasies.

7. Determine what anger they are projecting.

8. Help them to "synthesize." 


\section{Methods of Dealing with Conflict} MORE SOCIALLY ACCEPTED

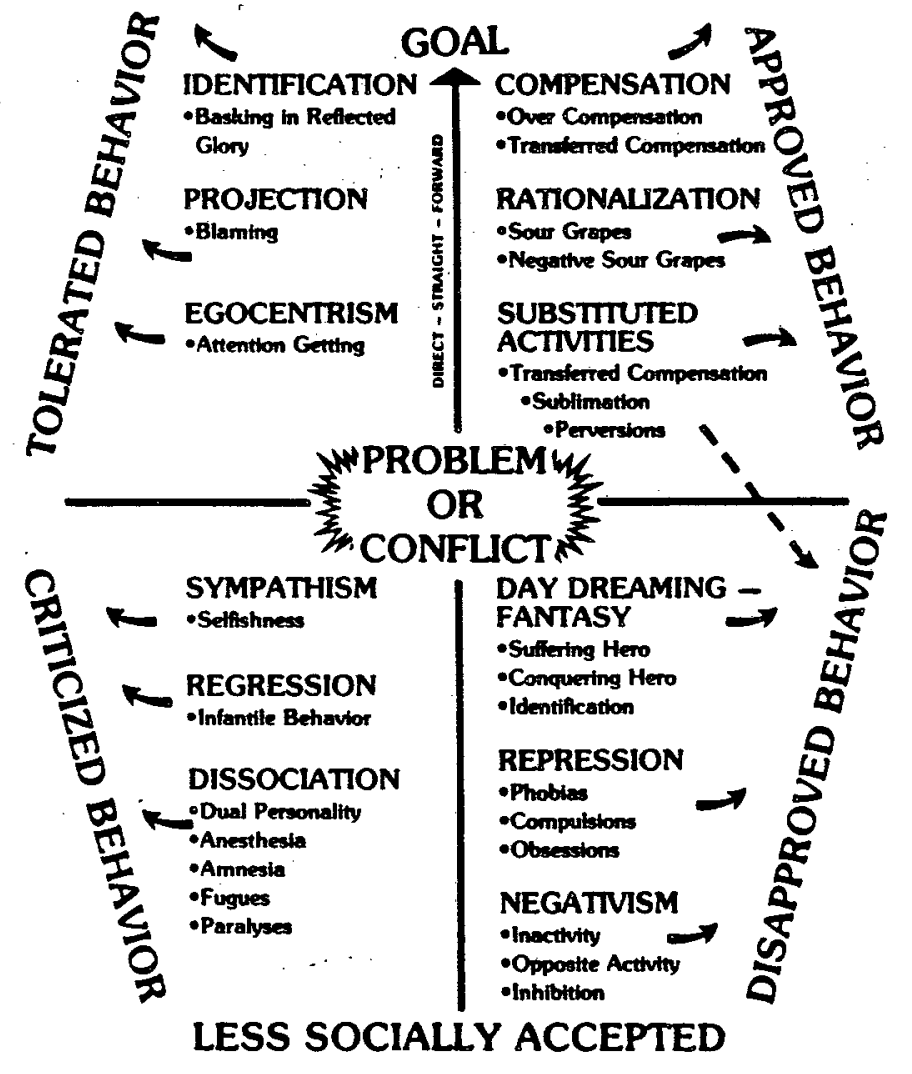

${ }^{1}$ Tim LaHaye and Bob Phillips, Anger $\underline{\text { is }}$ a $\underline{\text { Cho }}$ ice (Grand Rapids: Zondervan, 1982), p. 57 . 


\section{TWO LISTENING SKILLS: \\ "I FEEL" STATEMENTS, FOGGING 1}

It is difficult for most of us to respond to criticism or the anger that often underlies it. Criticism may be directed as a personal attack upon you, upon another person, or upon the church. When under the attack of criticism, we often become defensive and find ourselves feeling anger, belittled, or guilty, especially if there is truth in what the other is saying.

The problem with such feelings is that they of ten lead to blocked communication especially as they lead to defensiveness. This keeps us from fully hearing the other person and it does not help him/her deal with his/her negative feelings. Even when the criticism seems totally unjustified, a defensive response does not help deal with the issue.

Reactions to criticism:

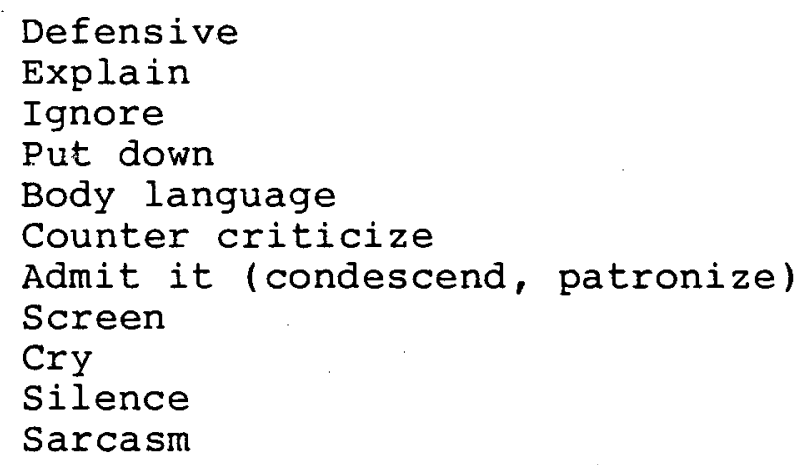

Certain responses can be helpful in dealing with criticism. These tend to keep communication flowing, to let the other person know he/she is being heard, and to deal with the feelings involved.

\section{Paraphrase}

One response is to let the other person know that you are hearing what he/ she is saying, and to make sure you are clear about what is being said. A paraphrase is putting

1 Adapted from Kenneth J. Mitchell and John $S$.

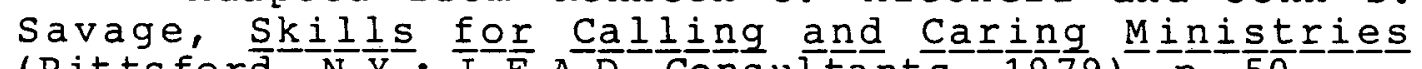
( $P$ it ts ford, N.Y.: L.E.A.D. Consultants, 1979), p. 50 . 
in to your own words what you heard from the other person. It is not analyzing, judging, or digging for more information; it is responding to what you hear. The tone of voice is extremely important with this skill.

"I want to make sure that I understand. You're upset that I didn't call to let you know that I would be late."

\section{Perception Check}

A perception check can be useful when the other person is not fully open with his/her feelings. It is a way of responding to nonverbal clues (tone, gesture) that are communicating feelings.

"Your tone of voice makes me think that you're pretty angry about that. Is that right?"

\section{"I Feel" Statements}

This response is an at tempt for you to be honest with your own feelings as you hear the other's criticism. It acknowledges that you are a person with feelings as well as the other, and invites a more personal relationship with the other. It is important that your own feelings be shared directly ("I" messages) and not indirectly ("you" messages).

Tone and gestures are very important if this is to be successful. You must project honesty, sincerity, and openness.

"I want to understand what you are saying, but I am aware that I am very uncomfortable with your statements."

\section{Fogging}

Fogging is agreeing with what is true for you. One of the quickest ways to defuse another's criticism is to agree with the truth in what they are saying. Fogging assumes that there is the possibility of truth in any critical statement, that it is important to listen for the element of truth, and to agree with it. It is not 
Conflict Skills Seminar Session $\mathrm{V}$

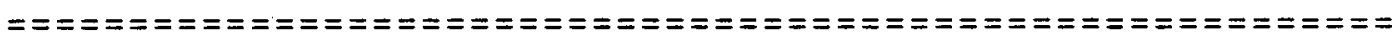
Page 3

agreeing with all that the other person says, but only with the part that may have some truth to it.

1. Critic: "The minister has not called on me for two months."

Fogging: "You're right. The minister probably does not call as often as some people would like him

2. Critic: "You're always late. Can't you be on time for once?"

Fogging: "Yes, I am of ten late. I'm sure that I could be on time more often."

3. Critic: "All the church wants from me is money."

Fogging: "You're right. The church doesn't hesitate to ask us all for financial support and you may have been hit with a lot of those calls. (Continuing with a perception check.) If it seems that all the church wants is money, that would be very upsetting. Is that right?"

None of these responses are sufficient alone. Mix your responses for effective communication. 


\section{LISTENING SKILLS PRACTICE}

This is a ROUND ROBIN practice of the active listening skills--"I feel" statements and fogging.

Divide into groups of three. There are three rounds of 5 minutes each in this activity. In each round, one of the three will be the "speaker", the "listener", and the "observer."

Speaker: Make a number of critical statements about the church, the church leadership, and the listener. After each statement, give the listener a moment to respond.

Listener: Your task is to deflect the criticism by following fogging techniques.

Observer: Watch listener for use of the skill of fogging. Make notes of the behaviors you see and hear. You will share your observations with the listener in order to help him/her improve his/her listening skills.

Format of each round:

Three minutes: Speaker shares

Listener actively listens

Observer is silent and takes notes

Two minutes: Observer shares observations All three discuss listener's behavior

Rotate for next round: speaker becomes listener listener becomes observer observer becomes speaker

Repeat the round robin three times. 


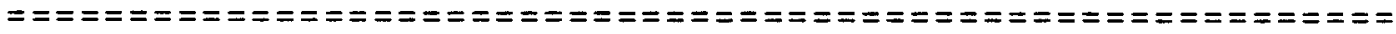

READING :

"ANGER AND YOUR TEMPERAMENT"

Following is a chapter from Tim LaHaye's book, Anger is a Choice. Read it carefully noting how anger relates to each temperament and then answer the questions below.

1. List the key elements of anger for your temperament ás described by LaHaye.

2. How does your anger parallel LaHaye's description of anger in your temperament?

3. According to LaHaye, what dramatic changes occur in your anger when the spirit reigns in your life? 
far as my new nature is concerned; but there is something else deep within me. In my lower nature, that is at war with my mind and wins the fight and makes me a slave to the sin that is still within me. In my mind I want to be God's willing servant but instead I find myself still enslaved to sin.

"So you see how it is: my. new life tells me to do right. but the old nature that is still inside me loves to sin. Oh, what a terrible predicament I'm in! Who will free me from my slavery to this deadly lower nature? Thank God! It has been done by Jesus Christ our Lord. He has set me free" (Romans 7:15-25).

"I advise you to obey only the Holy Spirit's Instructions. He will tell you where to go and what to do, and then you won't always be doing the wrong things your evil nature wants you to. For we naturally love to do evil things that are just the opposite from the things that the Holy Spirit tells us to do: and the good things we want to do when the Spirit has his way with us are Just the opposite of our natural desires. These two forces within us are constantly fighting each other to win control over us, and our wishes are never free from thetr pressures" (Galatlans 5:16-17).

There is a struggle raging continually in our lives. It is the battle for the will-the will to do right. When a person recelves Christ, he or she receives a new resource for doing right-a new resource for dealing with the emotion of anger.

In the following chapters we will look at many different ways to deal with anger. These techniques and suggestlons will, however, be effectlve only as we allow Christ to control and guide through them. Before we examine these techniques, it is helpful to look at another strong influence on the emotion of anger . . . our basic temperament. 


\section{9. \\ Anger and Your \\ Temperament}

"I Just don't understand myself," Judy said with tears streaming down her face. "Clyde said that he's had it. That he is through. He sald he couldn't take any more of my perfectionism. Can 1 help it if I like a clean house and he is messy? l've always been neat and organlzed. No one else in the family seems to care."

What made Judy so tidy and Clyde so disorganized? Was it just the way they were raised? Was it just the different environments in which they grew up?

Numerous theorles have been generated in an attempt to explain man's behavior. The anclents emphasized man's inherited traits as the cause for his actions. Freud and his followers blamed man's environment and childhood experiences. Actually, both contribute to our conduct, but our inherited temperament influences us most.

Through the genes at conception. man inherits from his parents and grandparents his entire nature. Including the color of his halr, eyes, body structure, talents and, of course. his temperament. That temperament acts as the single most powerful influence on his behavior, for it is the cause of his spontaneous actions and reactions.

Occasionally some of the brainwashed victims of modern psychology try to accentuate the significance of "learned behavior." but I find this suggestion rather puzzling. Consider. for example. four children all raised in the same basic home environment and subjected to the same training principles. Will they all act the same? No, they will be as different as night and day! Something dissimilar in their inherited ingredients must have caused this. One will be neat and 
orderly, and one will be messy. One will dress in "grubbles" and casual clothes, and the other in dress-up styles and coordinated outfits. These and a host of other differences will appear in their lives long before their parents have a chance to teach such things.

The Four Basic Temperaments

Made up of the traits we inherit at conception. temperament is Influenced later by childhood training, education. life experiences, environment, and both human and spiritual motivation.

The best theory of temperament was proposed by Hippocrates 2.400 years ago. He suggested that people fit into four basic categories: the sanguine super-extrovert salesman, the choleric extrovert strong-willed leader, the melancholy introvert perfectionist, and the phlegmatic super-Introvert passivist. Although varlations have been suggested, this theory is disseminated today very similar to its original form. Perhaps the key addition is that no one fits perfectly into one of Hippocrates' molds, for people tend to represent a blend of two or more of these temperaments. This seems to be a reasonable corollary. since they show physical characteristics of both the mother and father.

Most people tend to be predominantly one temperament with slight traits of another. It is not uncommon for a person to be 80 percent sangulne and 20 percent phlegmatic, or 70 percent choleric and 30 percent melancholic. There is no end of variations and percentages these traits may produce; one man 1 tested proved to be about 60 percent sanguine, 20 percent melancholy, and 20 percent phlegmatic.

\section{Temperament and Trancformed Temperamente}

The analysis of human temperament is one of the most fascinating subjects I have ever studied. Although it is tempting to launch into a comprehensive discussion of $\mathrm{It}$. I must deal with temperament here only as It relates to the problem of anger. For additional insights I suggest you read the followIng books: Sptrit-Controlled Temperament. Transformed Temperaments. Understanding the Male Temperament. and How to Develop Your Chlld's Temperament. ${ }^{1}$ 


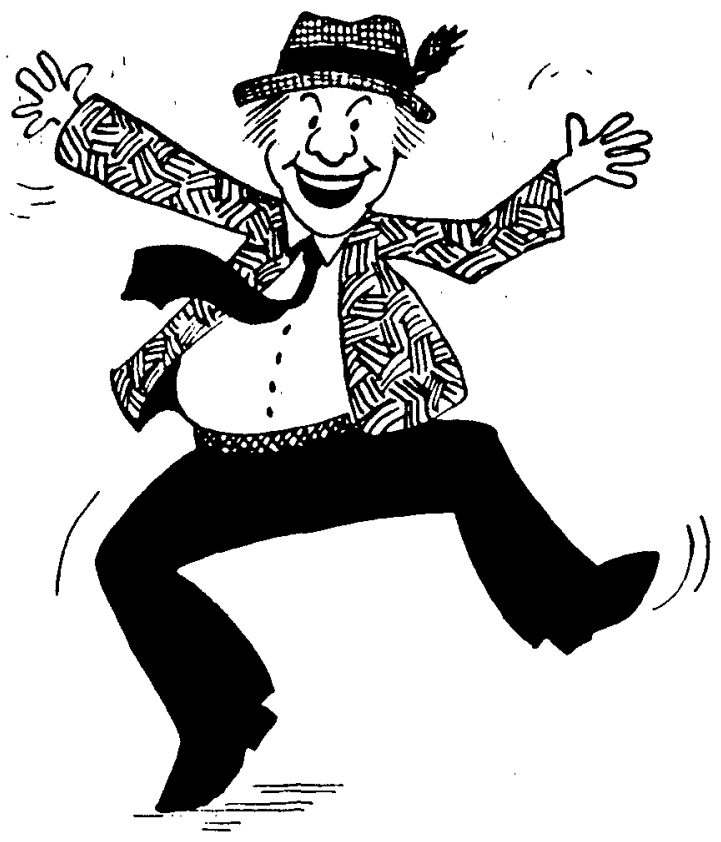

The Sangutne and Anger

The sanguine temperament breeds a warm. friendly, and outgolng person who draws people to himself like a magnet. He is a good talker, a happy-go-lucky optimist, the "life of the party." Though generous and compassionate. responsive to his surroundings and to the moods or feelings of others. like the other temperaments he features some natural weaknesses. He is often weak-willed. emotionally unstable and explosive, restless and egotistical. Voted "most likely to succeed" in his youth, he rarely measures up to expectations. He has great difficulty following through on detalls and is almost never quiet. Beneath his bold exterior he is often insecure and fearful. Sanguines make good salesmen, speakers, actors, and sometimes leaders. 
A sanguine is rarely depressed in the company of others. He is such a response-oriented person that the sight of another individual usually lifts his spirits and brings a smile to hls face. Whatever pertods of depression he does experience almost invariably occur when he is alone.

Many undisciplined sanguines experience anger. Their lack of discipline and weakness of will has usually made them rather unproductive, much to their chagrin and selfdisappointment. They are also prone to obesity because of their inability to refuse fattening desserts and other dellcacies. This lowers their self-esteem and heightens their tendency toward angry expressions. Although they usually go through the motions of responding happily to other people, their tendency toward anger will increase. One writer likened them to Peter Pan ... they wish never to grow up. Although they are well-liked and attractive, they are undependable and without real substance.

Sanguine individuals have a strong tendency to be disorganized and unproductive. You have probably heard about the sanguine businessman who rushed into the airport and up to the ticket counter and said, "Give me a ticket quick!" To which the clerk replied, "A ticket to where, sir?" "Anywhere," sald the businessman. "I've got business all over."

Their anger is of the "hot-flash" variety. They can explode faster than any other temperament. One thing about their anger, though. is that once they have exploded, they forget all about it . . . you don't but they do. They rarely get ulcers ... they give them to everyone else.

As these charming sanguines who often act like overgrown children become aware of their own shallowness, their insecurities are heightened. They become defensive, sensitive to slights or criticism, almost obsessed with others' opinions of them. It is not uncommon for them to become angry at this point. They may even blame their parents for Indulging them so much in childhood that they never developed selfdiscipline, but it is very difficult for them to blame themselves, confess their sin, and seek the filling of the Holy Spirit for the strength of character they so desperately need.

If they do not face their problem realistically and learn to walk in the Spirit, they will fluctuate up and down between 
anger and happiness for a tlme untul, in some chlldlike way, they make the mental adjustment and then go through life fixed in a playful position far beneath their level of potentlal.

Spirit-filled sanguines are different! The Holy Spirit convicts them that their angry thought patterns are sin, and guides them to those areas of productivity that make it easier for them to accept and appreclate themselves. When a sanguine is filled with the Spirit, like the apostle Peter in the Book of Acts, he or she becomes a productive and effectlve person not overwhelmed with anger.

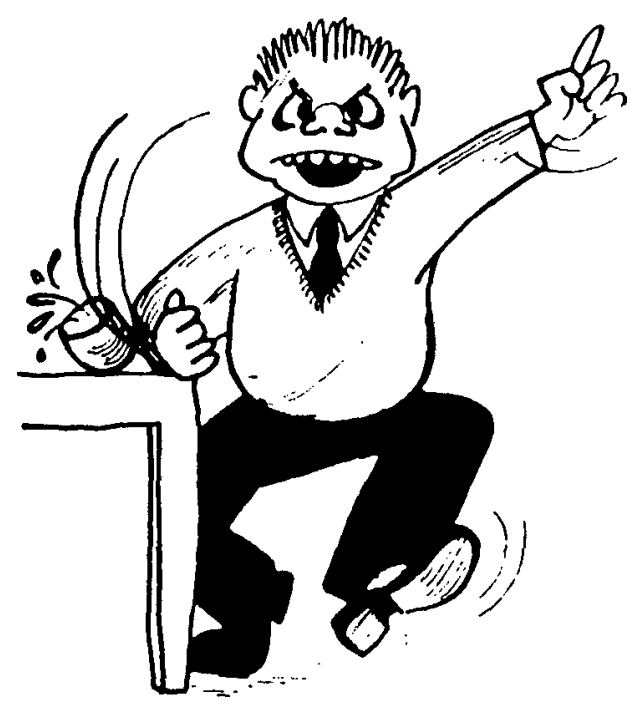

$\bigcup_{0}^{N}$

\section{The Cholerte and Anger}

The choleric temperament produces a practical activist. He is strong-willed, a natural leader, and very optimistic. His brain is filled with ideas, projects, or objectives, and he usually sees them through. Like Mr. Sangulne he is extrovert, 
but not nearly so intense. Although very productive in life, he reflects serious natural weaknesses. He is self-sufficient. impetuous, and hot-tempered, and he tends to be harsh or cruel. In fact, no one can be as cutting and sarcastic as a choleric. He makes a good supervisor, general, bullder. crusader, politician, or organtzer, but he is not usually able to do precise detall work.

The choleric rarely becomes depressed, primarlly because his active. goal-conscious mind keeps him so motivated that he projects fourteen different programs simultaneously. If one of them proves baffing or frustrating, his disappointment is short-lived and he quickly pursues a fresh challenge. Cholerics are happy when busy, and thus they have little time to be depressed. Their primary frustration in life is that there are not enough hours in the day to engage in their endless supply of goals and objectives.

Cholerics have a strong will and are very determined individuals. You may recall the story of the sanguine man married to his choleric wife. One day she came to her husband and said, "Henry. I want to buy a pair of scissors."

Henry replied, "We can't afford them."

The conversation went on like this:

"But I want them."

"I said no!"

"But I need them."

"The answer is no."

"Henry, I need those scissors!"

Henry responded, "Woman, if you say one more word about those scissors., I am going to take you outside and dump you down into the well."

"Scissors." said the choleric wife.

Henry then jumped up. grabbed her, and took her outside to the well. "Woman, if you promise not to say one more word about scissors, I will not throw you down the well."

"SCISSORS!" she replied.

"Okay, you asked for it!" With that Henry tied a rope on his wife and lowered her into the well. When she was halfway down, he said. "If you promise not to say anything about scissors, I"ll pull you back up."

"SCISSORS!" came the echo from the well. 
"That did it!" sald Henry. He let go of the rope, and his wife's head disappeared underwater. As Henry peered into the well, the only thing he could see was his choleric wife's hand stıcking out of the water. The first two fingers of her hand were moving back and forth in a scissors-like motion. Choleric individuals are very strong-willed and determined.

The rejection or insults that often set off other temperaments into perlods of depression never faze a choleric. He is so thick-skinned, self-sufficient, and independent by nature that he rarely feels the need for other people. Instead of feeling sorry for himself when alone. he spends the time originating new plans.

Emotionally he is the most underdeveloped of all the temperaments. For that reason he usually experlences very slight mood changes. Although he quickly becomes angry, he rarely Indulges in self-pity. Instead, he explodes all over everyone else. Because he is so insensitive to a person's opinion of him, he is not vulnerable to depression brought on by others. If a choleric ever battles depression. It will come as a result of frustration or retreat.

Unless he achleves victory over his anger early in life, the choleric becomes a very hostlle and bitter old man. He is unforgiving by nature and consequently usually has ulcers by the time he is forty years old. He is the one temperament that both gets and gives ulcers.

As a Christian, the choleric must learn to rest in the Lord and commit his way to Him. An Indomitable will and spirit of self-sufficiency often cause htm to be a useless, unproductive Christian because he insists on doing everything in the flesh instead of the Spirit. If he does successfully promote Christian activities, his pride makes him spiritually myopic and he falls to discern his carnal motivation.

The peace of the Holy Spirit that passes all understandjng will modulate his thinking pattern, causing him to concentrate on the Lord first and then on the task. He must learn that God's program does not depend on hIm; rather, he needs to depend on God. He must further recognize that fulfilling the work of God is not enough: he must do it in the power of the Spirit. As the Bible says. "Not by might, nor by power, but by my spirit, saith the Lord of hosts" (Zecharlah 
4:6. ksv). The apostle Paul, possibly the best illustration of a Spirit-filled cholerlc used of God, had learned this well, for he sald, "When I am weak, then am I strong" 2 Corinthlans 12:10, KJvl.

The flesh-filled cholerlc Christian can become angry untll he realizes this princlple, because he gets frustrated by the lack of spiritual results from his hard-driving. fleshly efforts. Instead of blaming himself for his carnal, self-willed spirit, he may swell up in self-pity and withdraw from his church activitles.

A choleric's carnal spirit is often easily discerned by others in the congregation, and thus he may be bypassed when officers are elected. "I don't understand," he complains. "Isn't my hard work sufficlent proof of my devotion to Christ?" Happy is the choleric who learns with James to say, "If the Lord will, we shall live, and do this, or that" (James 4:15, kJv). If he seeks the prioritles of the will of God through the leading of the Holy Splrit in his life, he will be not only more productive, but also more composed. When once he comprehends that walking in the Spirit is the secret to spirItual productivity, he will gain consistency in his Christlan life.

The abllity of the Holy Splrit to transform a choleric tendency to anger is illustrated superbly in the life of the apostle Paul. If ever a man was an illustration of choleric temperament, It was Saul of Tarsus before he became a Christian. renamed Paul. After his conversion, his Indomitable cholerlc will directed by the Holy Spirit surged forward throughout the events related in the Book of Acts.

Paul's response to confinement offers a classic illustration of circumstances overcome through the Invasion of man's spiritual nature by the Holy Spirit. Confined to the cold, clammy Mamertine Prison In Rome for preaching the Gospel. he manifested not one sign of self-pity. Instead, this dynamic Christlan took advantage of the opportunity to share his falth personally with every new Roman soldier assigned to him as a guard. So many of these men were converted that he addressed the church of Rome. "All the saints salute you. chlefly they that are of Caesar's household" (Philipplans $4: 22, \mathrm{ks}$ ). In addition, from this prison he penned the prison 
epistles, Including the epistle of joy called the letter to the Philipplans, in which he stated. "I have learned. in whatsoever state I am. therewith to be content" $(4: 11, \mathrm{kJv})$. Even Spirit-filled cholerics can have victory over angry outbursts.

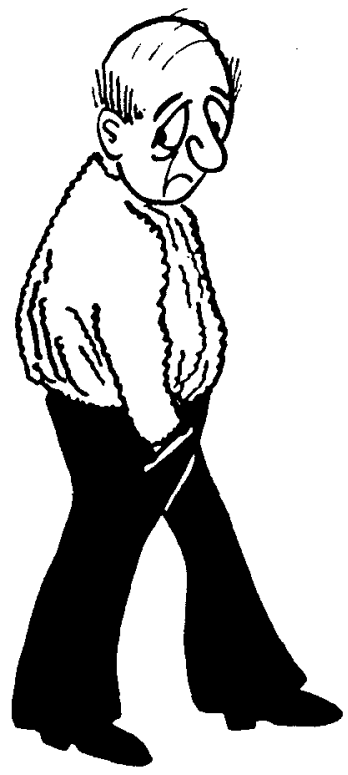

\section{The Melancholy and Anger}

The richest of all temperaments is the melancholy. Rich not only in gifts and esthetic appreciation. it has the capacity to experience the entire spectrum of emotional mood fluctuations. It is also rich in emotional weaknesses, particularly in the tendency to become angry and depressed. Some of the world's greatest genluses have been gifted melancholies who squandered their talent in the slough of despondency. becoming apathetic and unproductive. This is so much in evidence that the ancients frequently used the words melancholy and depresston interchangeably. 
The melancholy is usually the most talented of all temperaments. A natural perfectlonist, very sensitive and appreciative of the fine arts, he is analytical and self-sacrificing. As a rule he is not outgolng by nature and rarely pushes himself forward, but he makes a very falthful frlend. However, he tends to be moody, critical, pessimistic, and self-centered. The world's great artists, composers. phllosophers, inventors, and theoretictans have usually been melancholtes.

Although everyone is vulnerable to his own thinking pattern, none is more responsive than the melancholy. Among his other creative glfts, he harbors a great abllity to suggest Images to the screen of his Imagination-probably In living color with stereophonic sound. Because melancholles are moody by nature. they may regard their moods as spontaneous, but it has been learned that moods result directly from thinking patterns. If a melancholy guards his thought processes and refuses to indulge in the mental sins of anger. resentment, self-persecution, and self-plty, he will not yield to his predisposition toward depression.

One day several friends and 1 were dining in a restaurant. Suddenly a melancholy college-aged man with a gaunt look appeared at the edge of our table and asked, "Pardon me, but may I ask you folks If you were laughing at me?" Naturally we were shocked into sllence. Finally I sald, "Young man. I don't think we ve ever seen you before in our lives." With that he excused h/mself and walked away. Reflecting on the incident, we concluded that during our laughter and conversation. we must have looked in his direction. which gave this troubled young man the Impression that we were laughing at his expense. Equally as substantial are many of the depression-causing events in the life of the average melancholy.

\section{Melancholy Perfectionists}

Melancholles often are easlly depressed because they are perfectlonists. Most people could profit by having more perfectionist tendencles, but the true perfectionist $1 \mathrm{~s}$ made miserable by them. In the first place, he measures himself by his own arbitrary standard of perfection and becomes discouraged with himself when he falls short. The fact that his 
standard is usually so high that netther he nor anyone else could live by it rarely occurs to hIm. Instead, he Insists that his criterion for perfection is "realistic."

In addition to perfectionism he also is very conscientious and prides himself on being "dependable" and "accurate." Naturally all of his friends fall short of this standard. so it is not uncommon for him to become angry about himself and his associates. Very rigid and inflexible, he finds it difficult to tolerate the slightest deviation from what he considers to be the measure of excellence.

Such perfectionist-prone melancholles can love their children dearly while at the same time becoming angry with them. Children are notorlously disorganized and unpredictable; they follow their own schedules and insist on acting like children. A rigid melancholy parent finds it difficult to cope with such unpredictabllity and consequently may experience anger. Sometimes a melancholy mother may become ambivalent. loving her children intensely while at the same time being filled with anger and bitterness toward them. The carefree, happy-go-lucky tyke who insists on trekking across the clean kitchen floor in muddy boots can be a source of Irritation to any mother, particularly to a melancholy. Before she was married, she probably could not retire for the night until her shoes were lined up properly and the bathroom was in perfect order. Children automatically change that. but perfectionists find it difficult to cope with such change: consequently, depression is thetr outlet. They become angered at the lack of perfection in others and indulge in self-pity because they are the only ones striving for lofty goals. Such thought patterns invarlably produce anger.

In falrness to melancholy people. we note that they are as critical of themselves as they are of others. Consequently they tend to develop an Inadequate view of themselves. From early chlldhood they construct a disparaging self-image on the screen of their imagination. As they get older, they tend to reject themselves even more. unilke some of the other temperaments who learn to accept themselves. If they were permitted to verbalize their criticisms in childhood. they are apt to be verbally critical in adulthood. Each time they indulge In oral criticism. they only embed the spirit of criticism more 
deeply in their mind, and critics are never happy peoplel

One day I had an opportunity to see this principle in action. As I was passing through the security screening before boarding a plane, the security officer was criticizing the individuals who flew on that airline as "slovenly, inconsiderate, disorganized, and ungrateful people." I took it just about as long as I could, but finally, looking at him with a big smlle (I find one can say almost anything if he smiles). I observed. "You must be an unhappy man!"

He looked at me rather startled and replied. "Why do you say that?"

"Because you're so critical. l've never met a happy person who is a critical person."

After Inspecting my baggage, the officer sald, "Thank you, sir. I needed that." To my amazement he turned to the next customer and sald, "Hello. how are you? So glad to have you on our alrline."

I don't know how long the officer will profit from that experience, but I am certain he Is capable of making himself happy or miserable in direct proportion to the way he thinks of and talks to people.

\section{Self-Sacrifice and Persecution-Proneness}

Two characteristics of the melancholy short-circuit each other: the natural desire to be self-sacrificing and the selfpersecution tendency. Unless the melancholy is careful, this conflict will likely make a martyr out of him. Ordinarlly he chooses the most difficult and trying location to ply his vocation. When others seem to be more successful or gain more renown. Instead of facing realistically the fact that he has chosen the path of self-sacrifice, he Indulges in self-pity because his journey winds uphill and leads through arduous straits.

Melancholies rarely explode-at first. That is, if you insult a melancholy, he will usually react properly at the time. But after you're gone he will mull it over, stew about it. and become upset. When you see him two months later. long after you have forgotten the experience. he may "blow up" just at the sight of you. Melancholies have a slow-burning fuse that is very long. 
The determination of a melancholy to gripe and criticize merely compounds his negative thinking. perpetuates his anger, and ultimately brings him to despair. For this reason 1 Thessalonlans 5:18 can come to his rescue. If he painstakingly and consistently follows its formula, he will never become depressed: "In everything give thanks: for this is the will' of God In Christ Jesus concerning you". (kJv).

\section{Melancholy Creativity}

Fortunately for the melancholy. he possesses an unusual creative ability to project all kinds of images on the screen of his imagination. Once he fully realizes that positive feelings are the direct result of constructing wholesome mental images of himself and his circumstances, he is well on the road to recovery and prevention of future bouts with anger. Melancholy people risk anger primarily because of the continual misuse of their creative Imagination. That is, on the Imagination screen of their mind they project negativism. hurt, self-pity, helplessness, and despair. When they realize that thetr creative suggestions can work either for or against them, they can carefully project only those Images that are pleasing to God. Such thoughts will lift their spirits. stabilize their moods, and help them to avold anger.

\section{The Phicgmatic and Anger}

The easygolng, never-get-upset "nice guy" is the phlegmatic. Besides featuring a calm and likable disposition. Mr. Phlegmatic is a cheerful fellow who works well with other people. an efficient, conservative, dependable. witty person with a practical turn of mind. Since he is quite introvert, as a rule. his' weaknesses like his strengths are not so readily perceptible as those of other temperaments. His most obvious weakness is a lack of motivation. He can tgnore work graciously and is prone to be stubborn, stingy. and Indecisive. His abilIty to look at life through the eyes of a spectator may generate a tendency to avold "getting involved" with anything. Phlegmatics make good diplomats. since they are natural peacemakers. Many are teachers, doctors. scientists. comedians. and editors. When externally motivated, they make very capable leaders. 


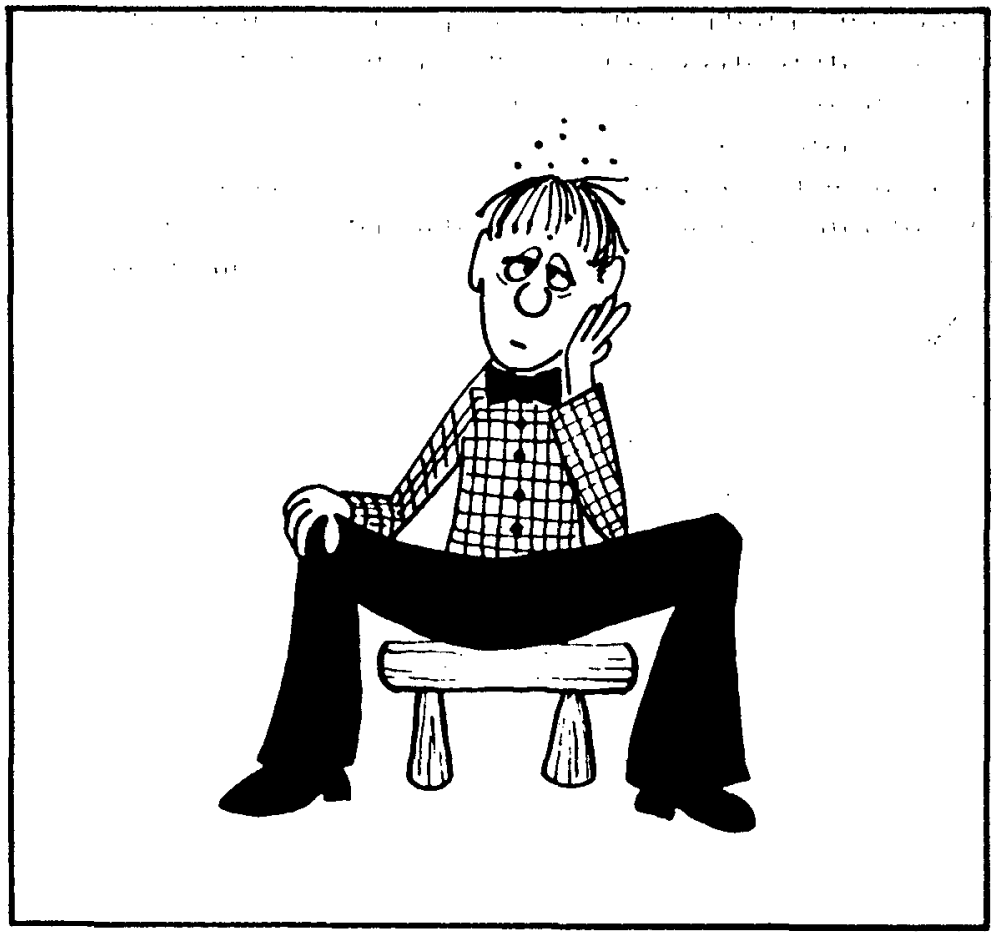

Generally a phlegmatic person is not easlly angered. He usually has such a high bolling point that he will seldom be explosive, though he may burn red inside. His unique sense of humor signals a happy outlook on life, and rarely does he reflect much mood fluctuation in elther direction. It is posstble to know a phlegmatic all his life and never see him truly angry. for no matter what the occasion, he tends to mentally excuse the person who has offended, injured, or rejected him. His abllity to adjust to unpleasant ctrcumstances is unbellevable to the other three temperaments, which find it easy to gripe or criticlze mentally and verbally.

If a phlegmatic ever does display anger. it is usually almed at his own lack of aggressiveness. Many times his practical, capable mind devilses a sultable plan of action for a given set of circumstances, but because of his passive Inclination or his fear of being crittcized by others, he keeps it to himself. 
Consequently; driven by famlly or other group pressure. he may find himself pursuing a plan inferlor to his own. This can produce Irritation which, when followed by self-pity, will make him angry. His anger is usually short-lived, however. because before long someone will come along who will amuse and entertain him.

There is one critical period in life when the phlegmatic is most vulnerable to anger. During the fifth or sixth decade he often becomes aware that the other temperaments have passed him by vocationally, spiritually, and in every other way. While he was passively watching the game of life as a spectator, his more aggressive friends were stepping through the doors of opportunity. His security-mindedness has checked him from attending upon daring adventures in life, and thus hls existence may seem rather stale to $\mathrm{hlm}$ during this period. If he indulges in self-plty. he will definitely become angry.

Instead of blaming his fear or Indolence, he finds it much easier to reproach "society" or "the breaks" or "my luck." Such a person should learn from the Lord Jesus early in life to attempt great things for God, for Christ sald, "According to your falth be it unto you" (Matthew 9:29, kJv).

\section{The Romed for Tomperament Woalonese}

God has a thrilling plan for overcoming all temperament weaknesses-even anger. In Epheslans 5:18 He designates it as being continually "filled with the Spirit." The filling of the Holy Spirit produces three great emotional characteristics:

1. A song in the heart (Epheslans 5:19);

2. A thanksgiving mental attitude (Epheslans 5:20);

3. A submissive spirit (Epheslans 5:21).

It is impossible to be angry when all three of these emotions are present: The filing of the Splrit, therefore, is the obvious remedy for the emotion of anger.

When Christians walk in the Spirit, they will maintaln the proper mental attitude so that they can respond in praise and thanksgiving to the negative circumstances of life. Remember. God has promised not to permit negative circumstances above our ability to cope with them. He is. of 
course, presupposing that we maintain the proper mental attitude.

Several components make up the right mental attitude. Consider them carefully to see if you possess them.

1. Complete commitment to the will and way of Cod (Romans $6: 11-13 ; 12: 1-2)$. Circle the percent of commitment you feel that you have at this point in your life. $10 \%$ 20\% 30\% 40\% 50\% 60\% 70\% 80\% 90\% 100\%

2. Knowledge of the princlples of God (Romans 12:2). No one will know perfectly all the principles of God for living. but you can dally refresh your mind on them by reading and studying the Word of God. I study the Blble ( ) Every day (1) Several times a week ( ) A couple of times a month () Rarely ( ) Never.

3. Falth (Romans 14:23; Hebrews 11:6). It is impossible to enlist the dynamic dimensions of God into your life without falth. If your faith is weak, don't wait for some miracle to make it strong. The following steps will strengthen your falth.

a. Hear, read, and study the Blble (Romans 13:10).

b. Pray for Increased faith (1 Corinthians 12:31).

c. Walk in the Spirit (Galatians 5:22-23).

d. Expertence faith (Romans 1:17) Each time you trust God for something, It is easier to trust Him the next time. I would like to trust God for the following: 


\section{0.}

\section{Is It Ever Right to Be Angry?}

"I feel so gullty," said Carla. "I have all these angry feelings Inside me, and I know that they are bad. I know the Blble says it is wrong to get angry, but I am angryl I know the Bible says to forgive, but I just can't do It! It's not fair what they did to mel"

Carla is not alone in her feelings. At some point in our lives, we all have experienced them.

The question then comes, Is it ever right to be angry? Are there situations and circumstances in which anger is legitimate? Is it possible to be angry and not be sinning at the same time? Can a "born-again." "Spirit-flled" Christian be angry and still be walking with God? Some people believe that all anger is sin. But how can we reconclle the Bible verses that tell us to stop being angry, not to seek revenge, to avold those who are angry, and not to harbor resentment with the apostle Paul's words, "Be angry and sin not"? It is not a small problem; many dedicated, godly men and women struggle with this.

Carla's story will help to tllustrate this dllemma. It is one of the most tragic I have ever heard in my counseling. As a very young child she overheard a conversation which revealed that the person she thought was her father was not. Being so young, the only thing she knew to do was to cry. With the passage of time. she repressed the hurt she felt.

When Carla was seven, she spent the summer with an aunt and uncle. It was not a happy time. There were angry words from the couple. Uncle Sid would slap her in the face and beat her with a belt. 
Conflict Skills Seminar Session $\mathrm{V}$

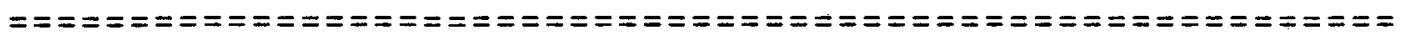
Handout $\mathrm{G}$

\section{LISTENING SKILLS EXERCISE}

Directions: This week find opportunities to use the listening skills taught to date. As you use them, notice the reaction of the other person. Fill in this sheet before Session VI.

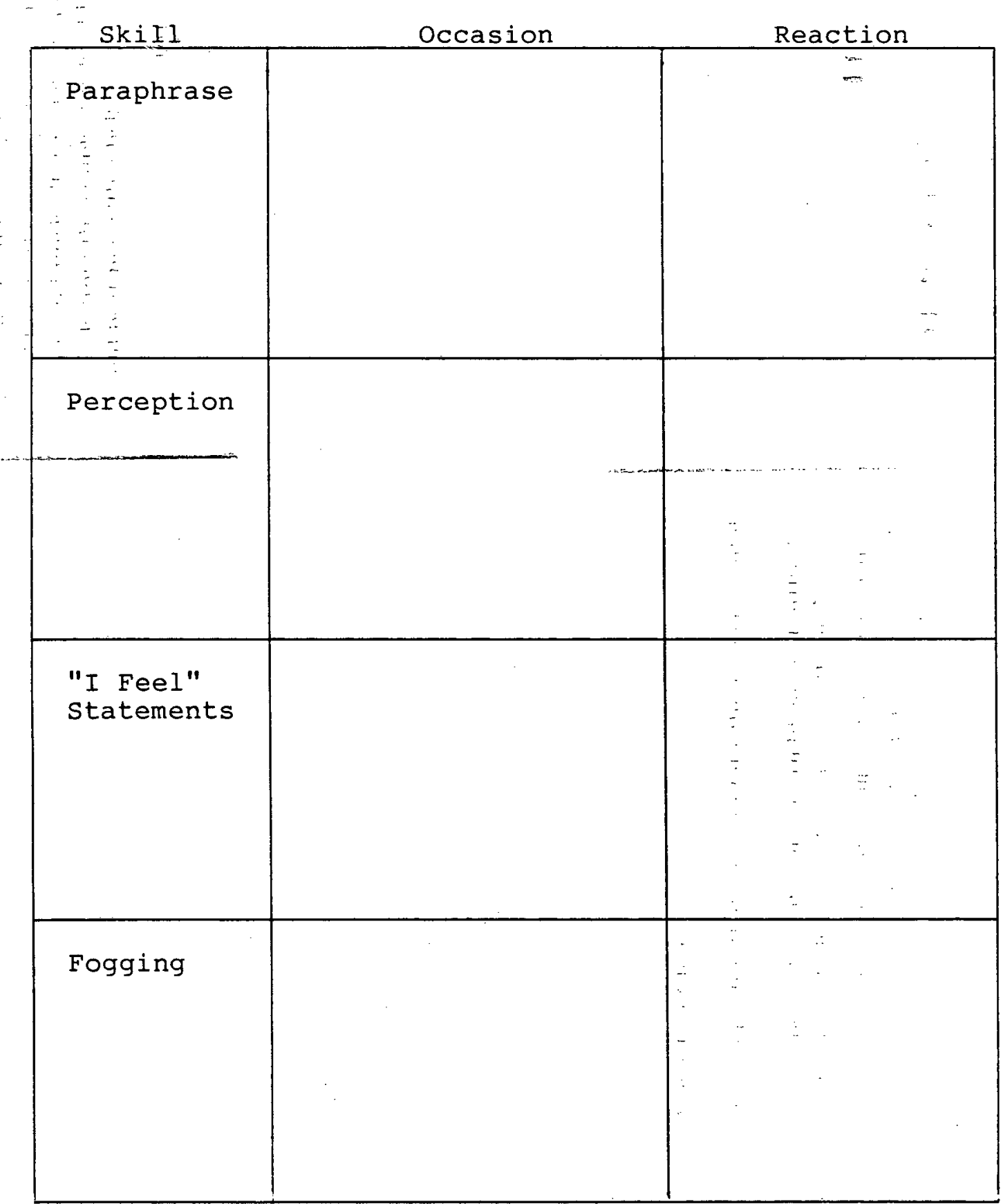




\section{ANGER INVENTORY ${ }^{1}$}

Read the list of twenty-five potentially upsetting situations described below. In the space provided after each incident, estimate the degree it would ordinarily anger or provoke you, using this simple rating scale:

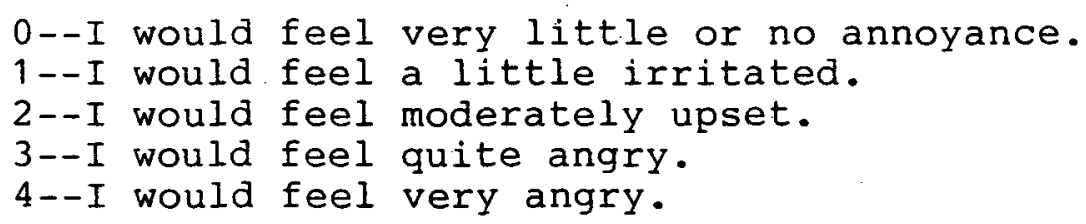

Mark your answer after each question as in this example:

You are driving to pick up a friend at the airport, and you are forced to wait for a long freight train. 2

The individual who answered this question estimated his reaction as a "two" because he would feel moderately irritated, but this would quickly pass as soon as the train was gone.

1. You unpack an appliance you have just bought, plug it in, and discover that it doesn't work.

2. You are overcharged by a repairman who has you in a bind.

3. You are singled out for correction when the actions of others go unnoticed.

4. You get your car stuck in the mud or snow.

5. You are talking to someone who doesn't answer you.

6. Someone pretends to be something he or she is not.

7. While you are struggling to carry four glasses of milk to your table at a cafeteria, someone bumps into you, spilling the milk.

${ }^{1}$ David D. Burns, Feeling Good: The New Mood Therapy (New York: William Morrow, 1980), pp. 137-40. 
Conflict Skilis Seminar

Session $\mathrm{V}$

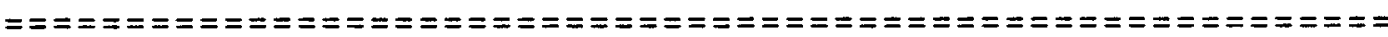

Page 2

Handout $\mathrm{H}$

8. You have hung up your clothes, but someone knocks them to the floor and fails to pick them up.

9. You are hounded by a salesperson from the moment that you walk into a store.

10. You have made arrangements to go somewhere, but the person backs out at the last minute and leaves you all alone.

11. You are being joked about or teased.

12. Your car is stalled at a traffic light, and the guy behind you keeps blowing his horn.

13. You accidentally make the wrong kind of turn in the parking lot. As you get out of the car, someone yells at you, "Where did you learn to drive?"

14. Someone makes a mistake and blames it on you.

15. You are trying to concentrate, but a person near you is tapping his or her foot.

16. You lend someone an important book or tool, and he or she fails to return it.

17. You have had a busy day, and the person you live with complains that you forgot to do something you agreed to do.

18. You are trying to discuss something important with your mate or partner, who isn't giving you a chance to express your feelings.

19. You are in a discussion with someone who persists in arguing about a topic he or she knows very little about.

20. Someone intrudes and interrupts an argument between you and someone else.

21. You need to get somewhere quickly, but the car in front of you is going $25 \mathrm{mph}$ in a $40 \mathrm{mph}$ zone, and you can't pass.

22. You step on a wad of chewing gum. 
Conflict Skills Seminar

Session V

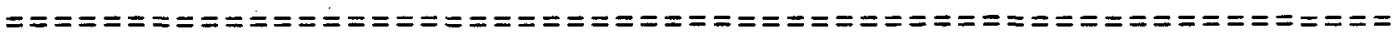

Page 3

Handout $G$

23. You are mocked by a small group of people as you pass them.

24. In a hurry to get somewhere, you tear a good pair of slacks on a sharp object.

25. You use your last dime to make a phone call, but you are disconnected before you finish dialing, and the dime is lost.

Calculate your score by adding your responses for the twenty-five incidents.

0-45 The amount of anger and annoyance you generally experience is remarkably low. Only a few percent of the population will score this low on the test. You are one of the select few.

46-55 You are substantially more peaceful than the average person.

56-75 You respond to life's annoyances with an average amount of anger.

76-85 You frequently react in an angry way to life's many annoyances. You are substantially more irritable than the average person.

86-100 You are a true anger champion, and you are plagued by frequent, intense, furious reactions that do not quickly disappear. You probably harbor negative feelings long after the initial insult has passed. You may have the reputation of a firecracker or a hothead among people you know. You may experience frequent tension headaches and high blood pressure. Your anger may of ten get out of control and lead to impulsive hostile outbursts which at times get you into trouble. Only a few percent of the adult population react as intensely as you do. 


\section{HOW TO FIGHT FAIR}

\section{OUTLINE}

I. Pre-session

Handout A--"Outline"

II. Feedback on the homework assignment (15 minutes)
A. Feedback on Handout F ("Anger and Your Temp- erament") from Session $V$.
B. Feedback on Handout G ("Listening Skills Exercise") from Session V.
C. Feedback on Handout $\mathrm{H}$ ("Anger Inventory Test") Session $V$.

III. Biblical study (13 minutes)

Handout B--"Care-fronting: A Biblical Necessity"
A Christian must at times confront others but in a caring way.

VI. Theory of Rational Emotive Training (10 minutes) Handout C--"Rational Emotive Training"

It is not that other people make us angry but that our irrational thinking about what they say or do that causes us to be angry.

\section{Listening skills ( 30 minutes)}

Handout D--"Loyalty Fighting Profile"

Nine elements that signify open communication.

VI. Small group practice (15 minutes)

Handout E--Listening Skills Practice"

Small group practice of the skills learned.

VII. Homework assignment ( 3 minutes)

Handout F--"Reconciliation"

Handout G--"Loyalty Fighting Practice Profile" Handout $\mathrm{H}--$ "Thoughts to Contemplate"

An at home reading assignment to develop an understanding of the role of reconciliation in conflict and a practice profile sheet for personal reflection. 
Read the following verses and be prepared to discuss the following points:

1) Who should confront and who should be confronted?

2) When should one confront?

3) What is the nature of Christian confrontation?

"Judge not, that you be not judged. For with the judgment you pronounce you will be judged, and the measure you give will be the measure you get. Why do you see the speck that is in your brother's eye, but do not notice the log that is in your own eye? Or how can you say to your brother, 'Let me take the speck out of your eye,' when there is the log in your own eye? You hypocrite, first take the log out of your own eye, and then you will see clearly to take the speck out of your brother's eye." Matt 7:1-5 (RSV).

"If your brother sins against you, go and tell him his fault, between you and him alone. If he listens to you, you have gained your brother. But if he does not listen, take one or two others along with you, that every word may be confirmed by the evidence of two or three witnesses. If he refuses to listen to them, tell it to the church; and if he refuses to listen even to the church, let him be to you as a Gentile and a tax collector." Matt 18:15-17 (RSV).

"Brethren, if a man is overtaken in any trespass, you who are spiritual should restore him in a spirit of gentleness. Look to yourself, lest you too.be tempted." Gal $6: 1$ (RSV).

"But when Cephas came to Antioch I opposed him to his face, because he stood condemned. For before certain men came from James, he ate with the Gentiles; but when they came he drew back and separated himself, fearing the circumcision party. And with him the rest of the Jews acted insincerely, so that even Barnabas was carried away by their insincerity. But when I saw that they were not straightforward about the truth of the gospel, I said to Cephas before them all, 'If you, though a Jew, live like a Gentile and not like a Jew, how can you compel the Gentiles to live like Jews?" Gal 2:11-14 (RSV). 
Conflict Skills Seminar

Session VI

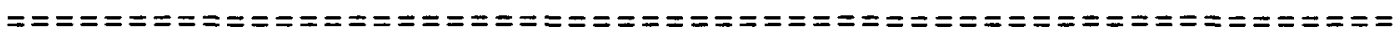

Page, 1

Handout $\mathrm{C}$

\section{RATIONAL EMOTIVE TRAINING}

The importance and role of feelings/emotions in mental health has recently been popularized by Albert Ellis and his student, Paul Hauck. Adventists, however, have had the witness of Ellen G. White who said years ago that if we think wrong our feelings will be wrong.

"If the thoughts are wrong the feelings will be wrong, and the thoughts and feelings combined make up the moral character." 5T 310.

Wrong thinking, then, produces wrong emotions. Or, to state it in reverse, negative emotions (fear, anxiety, anger, etc.) is a result of wrong thinking.

If I were to kick you, you could say, "I hurt you."

$$
\begin{aligned}
& \mathrm{A}=\mathrm{Kick} \quad \ldots-\ldots \mathrm{C}=\mathrm{Pain} \\
& \text { (Event) (Effect) }
\end{aligned}
$$

While this is true of physical pain, we cannot say the same for emotional pain. That is, if I say nasty and regretfully mean things about you, you cannot say "I hurt you." WORDS CANNOT HURT! The old taunt "stick and stones may break my bones, but words will never hurt me" is essentially correct. Instead, it is what you believed about those words that caused you to hurt. We might see it as follows:

$$
\begin{aligned}
& A=\text { Words } \ldots \ldots \text { B Belief } \ldots \ldots \text { Bemotional Pain } \\
& \text { (Event) (Effect) }
\end{aligned}
$$

Belief can be either rational (rB) or irrational (iB). It is the irrational beliefs that result in emotional pain. These irrational beliefs may relate to the following:

1) USTabation--"Life must be happy" or "You must do it that way or else." Basically, mustabation is the belief that things must be a certain way or it is not right.

2) $\mathbb{f}$ inimg--"It is just awful that I got sick," or "It is just awful that sister Jones said that." This is also called catastrophizing. That is, one sees catastrophic results in what occurs.

3) People-rating--some refer to this as 
Conflict Skilis Seminar

Session VI

$====$
Page 2

Handout $\mathrm{C}$

globalizing. That is, a person is seen as all bad or wrong because of one thing. "My wife nags, nags, nags, nags.. she is no good!"

This theory states that these irrational thoughts lead one to the kind of emotional pain that disrupts one's ability to cope with the situation in ways that would otherwise be open to him/her.

The purpose of this discussion is to help you dispute (D) your beliefs (B) about a situation so that you can see what might be the irrational nature of the beliefs that are causing you to feel angry. The diagram now looks like this:

$$
\begin{array}{lllll}
\text { A }----> & \text { iB }-----> & C-----> & D----> & E \\
\text { (Event) } & \text { (Belief) } & \text { (Effect) } & \text { (Dispute) } & \text { (New Effect) }
\end{array}
$$

This simple process can enable you to focus on what really troubles the majority of those who are disturbed. Instead of concentrating on the events (those things that you might perceive to be the problem), you can now evaluate your beliefs about the events so that the emotional effect is changed making your life more bearable and perhaps even pleasant.

The theory outlined above does not deny the fact that God holds people accountable for their words/actions that might cause another person to be angry or discouraged. Instead, it allows me to withhold the kind of personal judgment that breeds negative emotions. After all, judgment belongs to the Lord. Healthy thinking is reflected in Jesus' words on the cross, "Father, forgive them for they know not what they do." Remember, prior to that statement Jesus had endured the greatest suffering (events) at the hands of evil men. Instead of anger, however, Jesus felt pity (effects). This can be your experience as well--anger is a choice. 


\section{LOYALTY FIGHTING PROFILE ${ }^{1}$}

Interpersonal conflicts can be an opportunity for deeper intimacy (closer contact marked by warm friendship). This is only possible, however, if those engaged in conflict have learned to sharpen their communication skills. Our differences are often accentuated by our inept fighting techniques.

There are nine elements that form our communication profile. These can be placed on a chart and used to score our fighting profile. The elements are as follows:

1) REALITY. This element measures the authenticity of the fight. The fight may be labeled "realistic" if the fighter's aggression is based on justifiable, rational considerations that also feel real and authentic. The fight should be styled "imaginary" if the aggression is based on nonathentic reasons or if it contains elements of phoniness or game-playing.

2) INJURY. This dimension measures the fairness, unfairness, or meanness of the fight. The fight may be styled "fair" (above the belt) if the fighter keeps injuries within the opponent's capacity to absorb them. The fight is "dirty" (below the belt) if the aggression is hurtful and intolerable to the opponent.

3) INVOLVEMENT. This measures how seriously the fighter becomes involved in the aggression. The fight is "active" (reciprocal) if there is plenty of give and take. It is "passive" (or one-way) if the fighter displays an attitude of disengagment, if he is evading and avoiding or rolling with the punch; and/or, if the fight is not reciprocal but shows an attitude of, "Let the other fellow fight.".

4) RESPONSIBIIITY. This is a measurement of how the subject meets or declines responsibility for participating in the fight. The fighter is rated as "owning up" if he accepts his responsibility for placing (or responding in) the fight without enlisting support of others. The fighter is rated "minus" (anonymous or group) if he hides responsibility for his aggression or

${ }^{1}$ George R. Bach and Peter Wyden, The Intimate Enemy: How to Fight Fair in Love and Marriage (New York: Avon Books, 1968), pp. 159-166. 
parcels it out onto others ("The Pastor says. . .").

5) HUMOR. If one or both partners laugh, giggle, or joke during the fight, this dimension measures the purpose of the humor. The fighter rates a "plus" if humorous behavior brings some joyous relief to one or both partners, as for example when they laugh benevolently at each other, simultaneously or in relays. The fighter rates "minus" if he/she gets sarcastic enjoyment out of watching the opponent when he/she is down; if he/she ridicules the other or enjoys his/her suffering or embarrassment; if he/she clowns or is flip when the other is serious or disturbed; or if he/she tried to derail the other's concern by joking, etc.

6) EXPRESSION. This item evaluates the way the fighter's aggression is expressed. He/she rates "plus" (open, leveling) if his/her expression is overt, transparent, and not disguised; if he/she means what he/she says and the meaning is obvious. He/she is rated "minus" (hidden or camouflaged) if his/her manner of expression is covert, subtle, or open to considerable interpretation.

7) COMMUNICATION. This item measures the amount and clarity of verbal or physical communication that takes place in the fight. The fighter rates "plus" if communication is transparent, flowing openly, in quantity, freely, reciprocally; if it is effectively received with little misunderstanding; if the "noise level" of any interfering "static" is low; and if reception of the communication is acknowledged through feedback. The fighter rates "minus" if there is relatively little open communication, much interfering static, poor listening and receptivity, much redundancy or misunderstanding.

8) DIRECTNESS. This item measures to what degree the aggression is focused on the here-and-now opponent and his/her current actions--with no references to older or irrelevant situations. The fighter rates "plus" if his/her aggression is primarily directed to the present opponent and his/her current actions. The fighter rates "minus" if his/her aggression is related to the opponent but toward the past, or is displaced toward objects that the op ponent holds dear, such as children or persons or things or values.

9) SPECIFICITY. This item measures how much the attacks and counterattacks refer to the fighters' 
= = = = = = = = = = = = = = = = = = = = = = = = = = = = = = = = = = = = = = = = = = = = = Page 3

specific, observable actions, feelings, or attitudes as contrasted with fight tactics that generalize, interpret, or, for example, label certain of the opponent's behavior as "typical" of a broader personality trait. The fighter rates "plus" if his/her attacks and counterattacks are limited to directly observable behavior. He/she rates "minus" if by his/her actions the opponent is "analyzed" as belonging in a larger category or pattern.

The scoring process is designed to determine how a particular fight or fight round affected the mutual "swing" of the partners; whether the fight was relatively constructive or destructive.

Scoring may be done in one of four ways: 1) you may independently assign ratings to each other and then compare notes; 2) you may collaborte in determining the ratings; 3) you may ask a reasonably objective observer to rate them; 4) you may both work together with an objective outsider. 
Conflict Skills Seminar

Session VI = = = = = = = = = = = = = = = = = = = = = = = = = = = = = = = = = = = = = = = = = = = = = Page 4

\section{LOYALTY FIGHTING PROFILE}

\begin{tabular}{|c|c|c|}
\hline Imaginary & Minus $\left.\right|_{\text {REALITY }}$ Plus & $\begin{array}{l}\text { Authentic, } \\
\text { Realistic }\end{array}$ \\
\hline $\begin{array}{l}\text { Dirty, } \\
\text { Below the belt }\end{array}$ & INJURY & $\begin{array}{l}\text { Fair, } \\
\text { Above the belt }\end{array}$ \\
\hline $\begin{array}{l}\text { Passive, } \\
\text { One-way }\end{array}$ & INVOLVEMENT & $\begin{array}{l}\text { Active, } \\
\text { Reciprocal }\end{array}$ \\
\hline $\begin{array}{l}\text { Anonymous, } \\
\text { Group }\end{array}$ & RESPONSIBILITY & Owning up \\
\hline $\begin{array}{l}\text { Ridicule, } \\
\text { Clowing }\end{array}$ & HUMOR & $\begin{array}{l}\text { Laugh with } \\
\text { relief }\end{array}$ \\
\hline $\begin{array}{l}\text { Hidden, } \\
\text { Camouflaged }\end{array}$ & EXPRESSION & $\begin{array}{l}\text { Open, } \\
\text { Leveling }\end{array}$ \\
\hline $\begin{array}{l}\text { Static, One- } \\
\text { way, No feed- } \\
\text { back }\end{array}$ & COMMUNICATION & $\begin{array}{l}\text { High, Clear, } \\
\text { Reciprocal feed- } \\
\text { back }\end{array}$ \\
\hline Displaced focus & DIRECTNESS & Direct focus \\
\hline $\begin{array}{l}\text { General } \\
\text { "Analysis" }\end{array}$ & SPECIFICITY & Specific \\
\hline
\end{tabular}




\section{LISTENING SKILLS PRACTICE}

Directions:

1. Recall a conflict in which you were recently involved and evaluate your conflict responses on the Loyalty Fighting Profile.

2. Choose a partner. Select no more than three minus scores and discuss the strategy you plan to use to score pluses-in those areas. Each partner has six minutes.

\section{Time:}

3 minutes

12 minutes 


\section{RECONCILIATION}

Directions: Rewrite the following verse in your own words. Use creativity. Do not necessarily try to translate word for word. Rather, rewrite the ideas. Be prepared to share your ideas during the next class.

"And all things are of God, who hath reconciled us to himself by Jesus Christ, and hath given to us the ministry of reconciliation." 2 Cor $5: 18$ (KJV). 


\section{LOYALTY FIGHTING PRACTICE}

Directions: select a conflict that you experienced during the last week. Use the Loyalty Fighting Profile to score and analyze your response during the conflict. Be candid; this exercise will only be as valuable as you are honest about your responses. 


\section{LOYALTY FIGHTING PROFILE}

\begin{tabular}{|c|c|c|}
\hline Imaginary & Minus $\left.\right|_{\text {REALITY }}$ & $\begin{array}{l}\text { Authentic, } \\
\text { Realistic }\end{array}$ \\
\hline $\begin{array}{l}\text { Dirty: } \\
\text { Below the belt }\end{array}$ & INJURY & $\begin{array}{l}\text { Fair, } \\
\text { Above the belt }\end{array}$ \\
\hline $\begin{array}{l}\text { Passive, } \\
\text { One-way }\end{array}$ & INVOLVEMENT & $\begin{array}{l}\text { Active, } \\
\text { Reciprocal }\end{array}$ \\
\hline $\begin{array}{l}\text { Anonymous, } \\
\text { Group }\end{array}$ & RESPONSIBILITY & Owning up \\
\hline $\begin{array}{l}\text { Ridicule, } \\
\text { Clowing }\end{array}$ & HUMOR & $\begin{array}{l}\text { Laugh with } \\
\text { relief }\end{array}$ \\
\hline $\begin{array}{l}\text { Hidden, } \\
\text { Camouflaged }\end{array}$ & EXPRESSION & $\begin{array}{l}\text { Open, } \\
\text { Leveling }\end{array}$ \\
\hline $\begin{array}{l}\text { Static, One- } \\
\text { way, No feed- } \\
\text { back }\end{array}$ & COMMUNICATION & $\begin{array}{l}\text { High, clear, } \\
\text { Reciprocal feed- } \\
\text { back }\end{array}$ \\
\hline Displaced focus & DIRECTNESS & Direct focus \\
\hline $\begin{array}{l}\text { General } \\
\text { "Analysis" }\end{array}$ & SPECIFICITY & Specific \\
\hline
\end{tabular}


Conflict Skills Seminar

Session VI

= = = = = = = = = = = = = = = = = = = = = = = = = = = = = = = = = = = = = = = = = = = = =

Page 1

Handout $\mathrm{H}$

THOUGHTS TO CONTEMPLATE ${ }^{1}$

TIMING

old Self Instructions--catch them off guard:

Start the argument when least expected.

Drop the criticism when she's unprepared.

Raise the issue when he's overloaded.

spring the fight when she's overwhelmed.

choose the time that is best for you.

New Self Instructions--take time to set a time:

I want equal willingness, equal readiness, equal openness, at a mutually chosen, mutually satisfactory time.

TURF

old Self Instructions--pick your best turf:

spring the fight where you are comfortable.

slip the criticism in front of kids or guests.

Drop the bombshell just as you're leaving.

Pick the turf where you feel secure and the other insecure.

New Self Instructions--choose neutral turf:

I want equal comfort, equal security, equal freedom, in a mutually satisfactory place.

ATMOSPHERE

Old Self Instructions--step up the anxiety:

sulk to set the stage.

stall to build tension.

Salt with sarcasm.

Escape with busyness.

Top with hysteric overreaction.

Load with foreboding overcontrol.

New Self Instructions--set a caring atmosphere:

I want equal relaxation, equal genuineness, equal control, equal caring with mutual trust for each other.

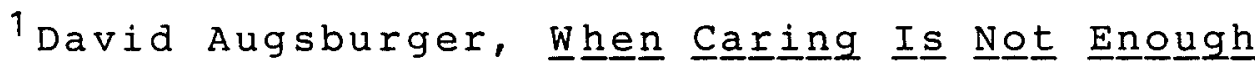
(Ventura, Calif.: Regal Books, 1983), pp. $36-7.0$. 
Conflict Skills Seminar

Session VI

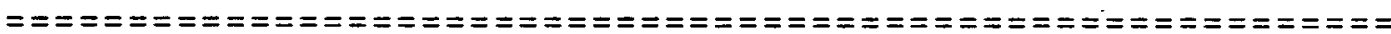
Page 2

Handout $\mathrm{H}$

\section{YIELDING}

Old Self Instruction--be nice, sweet, yielding: Sweet polite tact is the basis of human harmony. So all tensions must be temperate, frustrations are best forgotten, irritations are best ignored, differences can be deferred, smile, yielding is safer; overlook it, forget it, give up on it, sleep on it.

New Self Instructions--be genuine, honest, real:

I want a balance of honesty and openness, of caring for and candor with, of genuineness of loving and leveling, to excite health, and to invite growth.

FOGGING

old Self Instruction--filibuster, fog, fume:

Monopolize the time, inflate both facts and feelings.

Amplify pitch, volume, tone.

Agree with anything to evade.

Deluge them with data.

Overstate your case.

Overload the emotions.

Overwhelm their defenses.

New Self Instructions--seek equal communications:

I will respect your right to be equally heard.

I want to hear you.

I will claim my right to be equally heard.

I want you to hear me.

MYSTIFYING

old Self Instruction--ramble, chain react, mystify:

Learn to move quickly from issue to issue.

Ramble to confuse.

Meander to evade.

Switch quickly to mystify.

Chain react to overwhelm.

Keep multiple complaints going.

If one falters, flee to another.

New Self Instructions--seek mutual participation:

one issue at a time ( $I$ will wait until you feel heard). 
Conflict Skills Seminar

Session VI

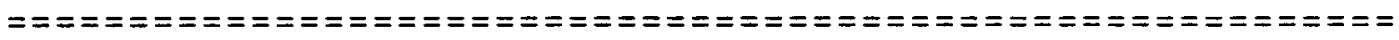
Page 3

Handout $\mathrm{H}$

One beef at a time (I will work until we both understand).

One argument at a time (I will seek for us both to win).

\section{GENERALIZING}

old Self Instructions--generalize, universalize, exaggerate:

Do not speak of a single instance; generalize on patterns of behavior--"you always," "you never," "you're forever."

Do not speak of one person; universalize on human behavior--"you're like all men," "that's a woman for you."

Do not speak of the actual extent; exaggerate to increase the impact--"you don't care at all," "you demand perfection."

New Self Instruction--focus, center, simplify:

Define the conflict narrowly--focus on the actual act, the present instance at stake.

Define the conflict neutrally--clarify, simplify, specify (reduce to the smallest unite of behavior).

Define the conflict naturally--center on the persons present and the particular behaviors in question.

ANALYZING

old Self Instructions--analyze, intellectualize, advise:

Analyze the other's shortcomings.

Critique the other's behavior.

Evaluate the other's choices (if she disagrees, it proves you were right).

Advise, to show it's their problem.

Help, to keep it at their doorstep.

Rescue with a vengeance (you're only doing it for his/her own good).

New Self Instructions--own my part in our pain:

I will own my part in our two-person problem.

When I analyze, I'm fleeing my fear.

When I intellecutalize, I'm fleeing my pain.

When I advise, I'm fingering the other. 
RECONCILIATION--THE GOAL IN CHRISTIAN CONFLICT

OUTLINE

I. Pre-session

Handout A--"Outline"

II. Feedback on the homework assignment (15 minutes)

A. Feedback on 2 Cor 5:18 using Handout F ("Reconciliation") from Session VI.

B. Feedback on Handout G ("Loyalty Fighting Practice Profile") from Session VI.

III. Biblical study ( 37 minutes)

Handout B--"Bible Study--What is Reconciliation?"

Handout C--"Bible Study--Effects of Reconciliation"

The primary goal in conflict between Christians is to maintain interpersonal relationships.

IV. Body language (20 minutes)

Handout D--"Nonverbal Behavior"

Handout E--"Encoding Messages--Emblems Practice"

The purpose of this discussion is to help the participants become more aware of the role that nonverbal behavior plays in communication.

V. Small group practice (20 minutes)

Handout F--"Body Language Feedback"

A feedback session in a small group setting for the purpose of exploring one's nonverbal behavioral patterns.

VII. Homework assignment ( 3 minutes)

Handout G--"Reading: 'Ministering to Antagonists'"

Handout $\mathrm{H}--$ "Thoughts to Contemplate"

An at home reading assignment to be completed by the next session. 
Conflict Skills Seminar

Session VII

= = = = = = = = = = = = = = = = = = = = = = = = = = = = = = = = = = = = = = = = = = = = = Page 1

Handout $B$

\section{BIBLICAL STUDY--WHAT IS RECONCILIATION?}

Directions: Divide into four groups. Study the scripture that is assigned to your group.

1) Read the text three times.

A. The first time your group should pretend it has never read the text before. What new things do you see?

B. The second time your group should pretend it has been hired by a dictionary company to consider meanings of words. Does everyone in the group understand the passage?

C. The third time your group should pretend it has to give a speech on this verse. What things seem most important? What single point might be emphasized?

2) Next, your group should discuss and record what point or points the text adds to your understanding of reconciliation.

3) Finally, your group should consider what the place of reconciliation is in God's plan according to the text.

". . that is, in Christ God was reconciling the world to himself, not counting their trespasses against them, and entrusting to us the message of reconciliation." 2 Cor 5:19 (RSV).

"So we are ambassadors for Christ, God making his appeal through us. We beseech you on behalf of christ, be reconciled to God." 2. Cor 5:20 (RSV).

"I appeal to you, brethren, by the name of our Lord Jesus Christ, that all of you agree and that there be no dissensions among you, but that you be united in the same mind and the same judgment." 1 Cor 1:10 (RSV).

"So if you are offering your gift at the altar, and there remember that your brother has something against you, leave your gift there before the altar and go; first be reconciled to your brother, and then come and offer your gift." Matt 5:23-24 (RSV). 


\section{MATCHING}

Directions: Match the scriptures with the best statement. Complete this exercise after the groups have reported.

1. Emphasizes man's work in the process of reconciliation.

2. Emphasizes God's work in the process of reconciliation.

3. God doesn't force us to be reconciled.

4. Emphasizes the individual's work in being reconciled to a brother.

5. God's action initiated the work of reconciliation.

6. Priority of reconciliation over worship.

7. Demonstrates that the innocent party acts in the reconciling process.

8. Reconciliation brings unity.

9. Demonstrates the part the church plays.
A. 2 Cor 5:19
B. 2 Cor $5: 20$
C. 1 Cor $1: 10$
D. Matt 5:23-24 
Directions: Return to your original group. Read Eph 2:11-22 for a case-study contrast in what the Ephesians were like before they were reconciled to God and what they were like after they accepted $\mathrm{Him}$ as Savior. Your group will be assigned the task of looking for either the "before" or "after" phrases, words, ideas, relationships.

"Therefore remember that at one time you Gentiles in the flesh, called the uncircumcision by what is called the circumcision, which is made in the flesh by hands-remember that you were at that time separated from Christ, alienated from the commonwealth of Israel, and stangers to the covenants of promise, having no hope and without God in the world. But now in Christ Jesus you who once were far off have been brought near in the blood of Christ. For he is our peace, who has made us both one, and has broken down the dividing wall of hostility, by abolishing in his flesh the law of commandments and ordinances, that he might create in himself one new man in place of the two, so making peace, and might reconcile us both to God one body through the cross, thereby bringing the hostility to an end. And he came and preached peace to you who were far off and peace to those who were near; for through him we both have access in one spirit to the Father. So then you are no longer strangers and sojourners, but you are fellow citizens with the saints and members of the household of God, built upon the foundation of the apostles and prophets, Christ Jesus himself being the cornerstone, in whom the whole structure is joined together and grows into a holy temple in the Lord; in whom you also are built into it for a dwelling place of God in the Spirit." Eph 2:11-22 (RSV).

BEFORE

AFTER

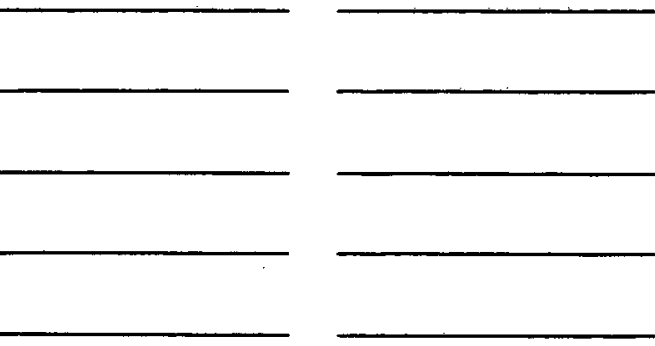




\section{NONVERBAL BEHAVIOR ${ }^{1}$}

Nonverbal behavior comprises $93 \%$ of our communication (body language 55\%, tone 38\%). Clearly, nonverbal behavior speaks more forcefully than our words. In fact, it is often a more accurate barometer of our innermost feelings. This being the case, we should train ourselves to notice and interpret the clues in the nonverbal behavior of others. Also, since it is a communication enhancer, we should learn to let our body language speak for us in positive ways.

Nonverbal behavior has been classified into the following categories:

\section{BODY MOTION OR KINESIC BEHAVIOR}

Body motion, or kinesic behavior, typically includes gestures, movements of the body, limbs, hands, head, feet and legs, facial expressions (smiles), eye behavior (blinking, direction and length of gaze, and pupil dilation) and posture. The furrow of the brow, the slump of a shoulder and the tilt of a head are all kinesic behavior. Obviously, there are different types of nonverbal behavior just as there are different types of verbal behavior. Some nonverbal cues are very specific while others are more general. Some are intended to communicate while others are expressive only. Some provide information about emotions while others carry information about personality traits or attitudes.

EMBLEMS. These are nonverbal acts which have a direct verbal translation or dictionary definition usually consisting of a word or two or a phrase. Usually the emblems are produced with the hands but not exclusively.

Examples:

$$
\begin{aligned}
& \text { "A-OK" } \\
& \text { "Peace" } \\
& \text { "Quiet" }
\end{aligned}
$$

ILLUSTRATORS. These are nonverbal acts which are directly tied to, or accompany, speech and serve to

${ }^{1}$ Mark L. Knapp, Nonverba 1 Communication in Human Interaction, 2 nd ed. (New York: Holt, Rinehart and Winston, 1978), pp. 12-20. 
Conflict Skills Seminar

Session VII

= = = = = = = = = = = = = = = = = = = = = = = = = = = = = = = = = = = = = = = = = = = =

Page 2

Handout $D$

illustrate what is being said verbally. These may be movements which accent or emphasize a word or phrase, sketch a path of thought, point to present objects, depict a spatial relationship, depict the rhythm or pacing of an event, draw a picture of the referent, or depict a bodily action, and emblems used to illustrate verbal statements, either repeating or substituting for a word or phrase.

AFFECT DISPLAYS. These are primarily facial configurations which display affective states: fear, anger, sadness, disgust, etc. Usually, these are not intended to communicate, but they can be intentional.

REGULATORS. These are nonverbal acts which maintain and regulate the back and forth nature of speaking and listening between two or more interactants. They tell the speaker to continue, repeat, elaborate, hurry up, become more interesting, give the other a chance to talk, and so forth. An example of a regulator is turn-taking which refers to the cues we use: to tell another person we want to talk, to keep another person from getting the floor away from us, to give up a speaking turn and ask the other person to continue, and to show we are finished speaking and the other person can take a turn. Generally, we don't say these things verbally; they are communicated by many nonverbal behaviors like head nods and eye behavior. If head nods occur frequently in rapid succession, the message may be "hurry up and finish," but if the nods follow points made by the speaker and appear slow, deliberate, and thoughtful they may signal, "keep talking" or "I like what you're saying." People trying to terminate a conversation often severely decrease the amount of eye contact with the other person. Regulators seem to be on the periphery of our awareness and are generally difficult to inhibit. They are like overlearned habits and are almost involuntary, but we are very much aware of these signals sent by others.

ADAPTORS. These nonverbal behaviors are labeled "adaptors" because they develop in childhood as adaptive efforts to satisfy needs, perform actions, manage emotions, develop social contacts, or perform a host of other functions. There are three types of adaptors: self-, object-, and alter-directed. Self-adaptors refer to manipulations of one's own body--holding, rubbing, squeezing, scratching, pinching, or picking. 
Conflict Skills Seminar

Session VII

$====$
Page 3

Handout $\mathrm{D}$

Examples:

$\begin{array}{ll}\text { picking nose } & \begin{array}{l}\text { comfort or frustration } \\ \text { sadness } \\ \text { wiping corner of eyes } \\ \text { covering eyes }\end{array} \\ \text { "scratch-pick" act } & \text { hostility/aggression }\end{array}$

Alter-adaptors are learned in conjunction without early experiences with interpersonal relations--giving and taking from another, attacking or protecting, establishing closeness or withdrawing, and the like. Leg movements may be adaptors showing a desire be aggressive or to flee.

object-adaptors involve the manipulation of objects and may be derived from the performance of some instrumental task--for example, smoking, writing with a pencil, and so on.

\section{PHYSICAL CHARACTERISTICS}

Body characteristics which are not movement-bound also communicate. They are influential in communication and affect interpersonal relationships. Included are such things as physique or body shape, general attractiveness, body or breath odors, height, weight, hair, and skin color or tone.

\section{TOUCHING BEHAVIOR}

Touching has been shown to be not only important in a child's early development but it also plays a role in adult communication. A casual touch to the arm or hand, stroking, patting, hugging, holding, guiding another's movements are examples of the touching behavior.

\section{PARALANGUAGE}

This deals with how something is said and not what is said. It deals with the range of nonverbal vocal cues surrounding common speech behavior.

VOICE QUALITIES. This includes such things a pitch range, pitch control, rhythm control, tempo, articulation control, resonance, glottis control, and vocal lip control.

VOCALIZATIONS. 1) Vocal characterizers include such things as laughing, crying, sighing, yawning, belching, 
Conflict Skills Seminar

Session VII

$====$
Page 4

Handout $D$

swallowing, heavily marked inhaling or exhaling, coughing, clearing of the throat, hiccupping, moaning, groaning, whining, yelling, whispering, sneezing, snoring stretching, and the like. 2) Vocal qualifiers include intensity (overloud or oversoft), pitch height (overhigh to overlow), and extent (extreme drawl to extreme clipping). 3) Vocal segregates include such things as "uhhuh," "uh," "ah," and variants thereof.

\section{PROXEMICS}

This deals with social and personal space including seating arrangements, spatial arrangements as related to leadership, communication flow, and the task at hand. The term "territoriality" is often employed to denote the human tendency to stake out personal territory--or untouchable space--much as wild animals and birds do.

\section{ARTIFACTS}

Artifacts include the manipulation of objects in contact with the interacting persons which may act as nonverbal stimuli. These artifacts include perfume, clothes, lipstick, eyeglasses, wigs and other hairpieces, false eyelashes, eyeliners, and the whole repertoire of falsies and "beauty" aids.

People can learn to recognize and interpret nonverbal behavior on the conscious level as well as change or modify their own nonverbal behavior. There are three aids to change:

FEEDBACK. One source of developing your nonverbal skills resides in the feedback you receive from others and your sensitivity and receptivity to it. Ironically, some feedback will be in the form of subtle nonverbal cues--the very thing you are trying to learn. Nevertheless, situations which provide you with an opportunity for feedback and interpersonal "coaching" will certainly be preferred over situations where feedback is minimal, coaching is inhibited, and your receptivity to feedback is low.

ROLE-PLAYING. Role-playing integrates knowledge with behavior.

INFORMATION. Information on nonverbal behavior can be obtained from numerous books and articles on the subject as well as from lectures. 
Directions: Encode the following messages into a symbolic gesture.

1. Sit down beside me

2. Be silent, hush

3. Wait-hold it

4. Get lost

5. Follow me

6. Stop

7. Look!

8. Take it away

9. Go ahead

10. What time is it?

11. I'm hot and it's hot

12. A close shave

13. I'm full of food

14. I've got a headache

15. Tastes good

16. How could I be so dumb?

17. He's crazy and He's stupid

18. I don't know

19. I promise

20. I'm angry

21. I'm sad

22. I'm surprised

23. Yes, I agree

24. Me

25. Gossip

26. Suicide
27. Come here

28. I can't hear you

29. I warn you

30. Be calm

31. Time to go

32. Go the other way

33. Go away

34. Go this way

35. Hurry and quickly

36. Stay here

37. Hard work

38. It's cold and I'm cold

39. I've got a toothache

40. I am smart

41. Shame on you

42. OK

43. Woman with a nice figure

44. I doubt it

45. I'm disgusted and something stinks

46. Good-bye

47. You

48. Hitchhiking

49. Money

50. Good luck

51. Counting

52. Finished 


\section{BODY LANGUAGE FEEDBACK}

Directions: Divide into groups of three and complete the three exercises listed below. Make notes for the discussion that will follow.

1) Identify the various nonverbal behaviors that might be associated with each of the following: (Hint-think of your own nonverbal activity in specific situations where these are present.)

Wish to appear sincere:

Wish to get away from an uncomfortable conversation or situation:

Wish to be open and honest:

Wish to hide or cover up something--fear of exposure:

Anger: 
Conflict Skilis Seminar

Session VII

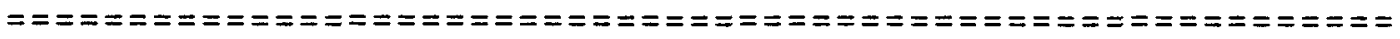
Page 2

Handout $F$

2) What nonverbal behaviors do you display that you have not already listed above. List five behaviors and the circumstances in. which they are likely to be displayed:

Behavior:

Circumstance:

1.

2 .

3.

4 .

5 .

3) List as many nonverbal behaviors that you can in the time remaining that enhance positive and constructive communication between individuals (private conversation) and between an individual and a group (public speaking). 


\section{READING: "MINISTERING TO ANTAGONISTS"}

Directions: Read the article "Ministering to Antagonists." Though the article is written from a pastor's viewpoint, consider yourself the church leader and put yourself his place. Answer the following questions.

1) According to the author, what is the greatest obstacle to happiness among church leaders.

2) List the three basic attacks that antagonists make on church leaders.

3) Notice the five methods the author suggests be used to deal with an antagonist. Evaluate his suggestions based on what you now know about conflict.
A) Disarm and neutralize them.
B) Do not give an antagonist more attention than is necessary.
C) Present a united front.
D) Treat the problem as a congregational one, not a personal one.

E) Give the antagonist enough rope.

4) Evaluate the author's suggestions as to one's personal response to antagonists. Which of his suggestions would you likely not use? Why? What are his two strongest suggestions? Why? 


\section{Ministering to Antagonists}

\section{RONNIE LITTLEJOHN}

One afternoon a pastor friend of mine sat in my office sharing with me the relentless pressure he was receiving from a few families in his church. Using the telephone and various informal occasions, these families were carrying on an active program of subversion and criticism. Although these antagonists disclaimed that they were trying to force my friend's resignation, they were destroying his effectiveness as a leader. What is worse, they were causing him so much personal stress as to make him doubt his own competency and call.

A few days later a discussion at our community ministerial alliance revealed that nearly all of the church staff members present had had such problems as my friend was facing. It occurred to me that the basic obstacle to happiness in church vocations had very litrle to do with theology or proper biblical interpretation. On the contrary, the nagging exaggeration of what was said (or not said) to this or that person; the opposition over moving a Sunday School class; the different impressions over what games to play in the fellowship hall; or how many hymns to have the congregation sing as opposed to the number sung by the choir all seem to be much greater threats to a happy and fruitful ministry. Invariably, my experience has been that the issues which are most relevant to the everyday operation and happiness of a congregation, are those which my academic experience minimized.
I wish to share some observations about dealing with antagonists in our congregations. In doing so, I will attempt to avoid any speculation on why some people tend to be antagonists. I am more concerned with what to do when such individuals attack and how to prevent such attacks whenever possible.

\section{Knowing When You Are Being Attacked}

I know it sounds odd to suggest that someone would be attacking you and you not know it. However, it happens! Sometimes it occurs because the staff member is unaware of what is beiris said. More often though, staff members simply misread the potentially serious nature of antagonistic and critical remarks. Have you ever been under attack? Well, do not answer "no" too quickly. Most attacks involve some combination of the following. See if you recognize their imprint on your ministry.

(1) Accusations-An antagonist may accuse the staff member of being lazy or insensitive. For example, "the pastor doesn't visit enough," or "all the pastor's sermons make the same point," or "the pastor doesn't get church approval for anything," or "the pastor caters only to the young (or old) people." Often these accusations are lodged in statements said half-jokingly, but their seriousness should not be underestimated.

(2) Intimidation-The antagonist may imtmidate you in many ways. Perhaps the most frequently used form of intimidation is the appeal to a substantial following. An individual may say to you, " many people have said they don't like that new program of yours," or "I'm not the only one who thinks this way, everybody l've talked to agrees with me."

Vague phrases like "many people," and "everybody" create a feeling of insecurity in most staff members. However, the very lack of specificity inherent in these terms should be a clue to the staff member that these estimates are not to be taken literally.

Other forms of intimidation include phone calls or secret meetings used by the antagonist to garner support.

(3) Threats-It is a threat when someone begins to pay extraordinary attention to how you use your time. Most church members are unaware of the large amounts of time staff members invest in evening and weekend work. They simply do not realize how ever-present a minister's job is. It is not unusual to counsel a man about his marriage while at the car wash, and how many "days off" have you spent with a bereaved family! Antagonists who are insensitive to such use of your time may see you at the barber shop, or the tennis court, or the grocery store during the week and conclude that you are not using your time wisely.

Antagonists may threaten to leave the church and take others with them, or they may threaten to resign from the office or committee they hold. Of course, the most 
serious threat occurs if the antagonist threatens to seek the censure or termination of a staff member.

What to Do With An Antagonist

(1) Disarm and neutralize them.

Talk to the antagonist, satisfy objections if possible and reasonable. Admit your errors if they are real. Point out where criticisms are misplaced or inaccurate if they are. Above all, be in control of the situation. Very often antagonists will defuse themselves after talking with you.

(2) Do not give an antagonist more attention than is necessary. Many antagonistic attacks are probably attempts at getting attention. Strangely, those who protest about not wanting recognition or attention, are often those who desire it most.

Siructure open meetings in such a way as to prevent the antagonist from having more time on the agenda than is warranted. As a general rule, never allow antagonists to speak before groups or committees to which they have not been elected.

(3) Present a united front. Arrange for antagonists to have freouent contact with people who support you, your activities, or your program. These persons do not necessarily have to defend you. They may simply not listen to the antagonist. However, do not hesitate to use other church leaders and staff members as your shield in time of trouble.

There is a danger here. Be careful to avoid creating a faction or division in your church. There is a real question about whether a staff member is ever justified in splitting a church.

(4) Treat the problem as a congregational one not a personal one. Make it a point to avoid sounding personally defensive. When the issue surfaces (and that should always be at a time of your choosing), be sure to emphasize the broad implications and church-wide effect of the antagonist's challenges.

Always require an antagonist to work through the proper channels. With the right preparation,
298

personnel committees, church councils, deacons, can handle a problem without it becoming a source of stress and division.

(5) Give the antagonist enough rope. T do not mean for this to sound harsh. Yet, there are times when an antagonist should be allowed to state his case before some appropriate group. Of course, these instances should be carefully monitored. The key is to allow an antagonist to state his argument when he persists in ignoring significant information, records, or points you have made.

\section{What to Do With Yourself When Antagonists Attack}

(1) Business_as ysual. Be natural! If you must become unnaturally active in visitation, sermon preparation, communication, or friendliness, then the antagonist may have a case.

Work hard. Carry on. The effectiveness of what you are doing will drown out a lot of criticism about what you are not doing. If a program is ministering to people, an antagonist may soon realize the futility of attacking it. If it is not effective, then it should be reworked or terminated.

The most important reason to carry on as usual is that by doing so, some antagonistic attacks will die a natural death.

But be careful here. Many staff members believe that most antagonistic attacks are not serious, and will just go away if they leave them atone. This is not true. Most will not "just go away," but some Will. If ignored, the majority of antagonistic attacks will fester and become a constant source of anxiety. The staff member may become a paralyzed leader, afraid to make any really significant decisions.

(2) Be direct and confident. Never discuss personal problems with an antagonist. Avoid speaking of problems you are having with other members, especially in front of an antagonist.

Control the time, place, and length of meetings you have with an antagonist. If you have already tried to neutralize the situation, and it has not worked, then do not initiate other meetings unless you have very good reason to believe that they will produce a constructive resolution of the problem.

Remember that other affairs demand your attention. Let the antagonist know that he is being "worked into" your routine of visiting, counseling, administration, and sermon preparation. Do not be afraid to say you are too busy to talk to them.

(3) Exercise care when speaking of the antagonist. As a general rule, speak of the antagonist and/or the subject of the attack, only if asked a direct question. Even then, keep your response brief and non-inflammatory. Do not initiate discussions of problems you are having with an antagonist. Whatever you do, do not use your visitation for political purposes. In fact, be consciously disdainful of opportunities to be critical or petty.

(4) Do not use sermons to counter-attack an antaganist. There may be two situations when it is ethically legitimate to use sermons in such a way that they actually serve as a counter-attack. For example, in those instançes when the point at issue is theological. One might preach a series on theological doctrines and include the controversial idea. Be fair in your treatment of opposing views, but state the biblical and historical grounds for your position. Above all, display the basic principle that one's tireotogy and the reality of one's faith are not identical. One can have a meaningful faith and a poor theology, and vice versa.

I) A second occasion when the

- pulpit might be used to counter or prevent ahtagonistic attacks is if you usualiy preach a "state of the church" message. Such sermons may clarify your priorities in ministry. However, such messages should not be direct attacks an an individual or group. These sermons should more clearly address your. perception of the minister's role.

(5) Keep good records. Know when you visited someone, how many visits you make per day, and what types of visits these are. File your sermons so that you can 
299

show their balance and themes. Keep minutes on committee meetings, and double check them for accuracy with the committee before the meeting is dismissed.

(6) Should you ever resign? The answer, of course, must be "maybe." If antagonists are right about one-third of the fime, then you probably need to make some changes. Perhaps you can consctentiously adapt. If you do not feel you can, then you should begin to pray about some direction for your future service.

If you are under tremendous strain, you may need to resign or take a leave of absence. It is always wise to take a weekend vacation every now and then. Leave town for a day or two. Get a new perspective and renew your objectivity.

As a general rule, do not resign when an antagonist is wrong. And do not resign hastily. In fact, avoid discussing this subject until you are actually prepared to resign.

\section{What to Do When Things Settle Down}

(1) Be ready to forgive or ask forgiveness. Resolve a problem at the earliest stage possible. Do not be afraid to ask forgiveness if you need to, but be sure you need to! Do not use forgiveness and apologies as a regular means to squelch disagreement. Such an approach is not only dishonest, but it will eventually become ineffective.

(2) Do not bring up the probTem. Regardless of how things are resolved, trouble will result from renewed discussion of the issue.

(3) Allow the antagonist to leave - If the antagonist leaves, do not 80 after him. Even our Lord did not give himseif to all men. If your sincere overtures to forgive and rechannel the service of the antagonist are not accepted, then let him resign, drop out, or leave. Of course, no staff member should do this with a light heart. However, every staff member should realize that there are times when it must be done. There are occasions when the productivity and spirit of your congregation will be greatly enhanced by the absence of some antagonists.

\section{Can Antagonistic Challenges Be Prevented?}

I am convinced that not all attacks can be prevented. Some are too irrational to predict, and therefore, there is little defense for them. But many attacks can be prevented. Some steps that will help prevent antagonistic challenges are listed below.

(1) Have a realistic perspective on the ministry. Too many church staff members expect one hundred percent support. Consequently, they exaggerate any critical comment into a major crisis. This need for approval can be an enemy. Be prepared to accept some criticism.

On the other hand, some staff members have fallen into a compassion trap. In a day when the humanity and vulnerability of the minister has been emphasized, many church workers are too quick to compromise, to change plans, to speak of their vocational weaknesses. The result is that in some cases antagonists are too much tolerated. There is a time to confront persons who are chronic antagonists.

(2) Make it possible to evaluate your ministry. Of course, some efements of your ministry can never be quantified and measured. But some can, and if you will represent these, many problems will be prevented and it will be much more difficult to criticize you. Additionally, you will have a sense of satisfaction because you will be able to have some gauge about what you are doing.

Make your visitation public. Carry cards with you. Leave them when people are not at home, when they are asleep or incoherent. Give a monthly report on your visitation. Perhaps you can use some adaptation from Lyle Schaller's book, Survival Tactics in the Parish.

Keep your sermons. Update your messages. Plan your preaching program.

(3) Detect potential antagonists. Pay attention to an individual's past. Take notice of persons who have been antagonists in the past in your congregation. Be alert to people who change churches often. Know when someone is exaggerating how well they know you, or how much you confide in them. Be sensitive to persons who are present only at business ineetings, but never at präyer meeling or Sunday Evening semices. Such persons are revealing their true priorities. They are telling you how they define church membership.

(4) Admit your errors. Do not do this all the time! I remember a lecture that John Claypool gave at Yale Divinity School the Beecher lectures) in which he said that one of the real perils of the modern minister is that in sharing his darkness, in an attempt to identify, he falls into all kinds of phoniness.

However, there are times when an antagonist has a case and you are best off to admit your shortcoming. In such situations, be sure that you are the one to expose and admit your error. You call the meeting, or make the announcement.

Ronnie Littlejohn is pastor, First Baptist Church, Rockdale, Texas. 
= = = = = = = = = = = = = = = = = = = = = = = = = = = = = = = = = = = = = = = = = = = =

Page 1

Handout $\mathrm{H}$

THOUGHTS TO CONTEMPLATE ${ }^{1}$

BINDING

old Self Instruction--activate ambivalences:

watch for conflicting feelings and point them out to the other.

Note any contradictions and highlight them to the other.

Use his words to disprove his point.

set her thoughts against herself.

Mix up emotions to split feelings.

Polarize views to confuse perceptions.

New Self Instructions--one side at a time:

For these I am fully responsible:

The thoughts I think are mine no matter how conflicted.

The feelings I feel are mine no matter how mixed.

The views I hold are mine no matter how contrary.

For these I am fully responsible:

Your thoughts and feelings, and your values and views are yours no matter the contradictions.

\section{GUNNYSACKING}

old Self statements--gunnysack grievances:

Collect hurts.

Accumulate slights.

Remember injustices.

Brood on injuries.

When loaded to the gills, get it off your chest.

Keep grievances on file to balance any losses or to justify any acts.

New Self statements--deal with here and now:

I will finish my anger at past predicaments of failure.

I will cancel my anger of future predictions of failure.

I will work through the anger felt here.

I will open the future to risk being real now.

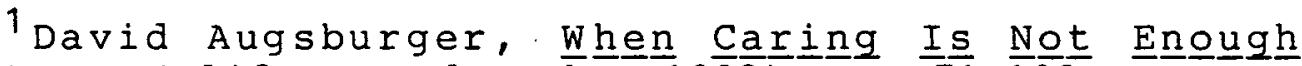
(Ventura, Calif.: Regal Books, 1983), pp. $71-102$. 


\section{NEUTRALITY}

old Self statements--be silent, superior, neutral:

"Silence" is strength (be unavailable).

stonewall by keeping mum (don't get hooked).

"Superiority" is security (be unreachable)。

Stay cool, stay uncommitted (don't get involved).

"Neutrality" is safety (be untouchable).

Rise above the situation (don't touch or be touched).

New Self statements--be open, present, available:

"Silence" is violence, openness is strength. Risk!

Share!

"Superiority" is flight, presence is power. Hurt!

Heal!

Neutrality is numbness, contact is aliveness. Touch!

Feel!

\section{ANGERING}

Old Self Instructions-hide anger; ventilate rage:

Don't admit to anger when denial is possible (I'm not angry, I'm just concerned).

Don't give them the satisfaction of knowing that they got to you (I'm not angry, I'm above that!).

Then blow up when they least expect it or don't get mad, get even.

New. Self Instructions--own anger clearly:

I will own my anxiety,

accept my anger,

admit my irritation,

describe my demands, assert those that are just,

cancel those that are unfair so that my arousal will both clear the air and show I care.

RUMORING

old Self Instructions--play detective:

Keep a file for future use.

Listen in on the phone extension.

Read your children's diaries. 
Conflict Skills Seminar

Session VII

= = = = = = = = = = = = = = = = = = = = = = = = = = = = = = = = = = = = = = = = = = = = Page 3

Handout $\mathrm{H}$

Go through your spouse's purse. Quize your children's friends.

Keep your eyes open for clues

Save any tidbits for ammunition, never waste it before a fight.

New Self Instructions--refuse hearsay:

Report only on recent events.

Refuse secondhand data.

Collect no anonymous stories.

Seek no covert information.

Save no painful memories.

Stay with the here and now.

Deal with firsthand experience.

BLAMING

Old Self Instruction--blaming and shaming:

Whatever goes wrong is somebody's fault, fix the blame.

Whenever something fails someone must suffer.

Stir up shame

(quick before you get blamed)

(better them than you shamed).

New Self Instructions--affirming responsibility:

You are responsible for whatever you do.

You are never to blame.

We are each responsible for whatever we do.

We need not feel shame.

WHO'S RIGHT?

old Self Instructions--find who's right:

Keep the focus clean, clear.

Keep the issues sharp, simple.

Either/or, right/wrong, true/false, nice/nasty.

Some people are wrong (like you, no offense intended).

Some people are right (like me, how can I help?). Admit it, face it, let's get on with it.

New Self Instructions--find what's right:

The central issue is:

not who, but what,

not which one of us, but which way for us.

My perspective is not "right," nor your point of view "wrong."

Each is corrected, completed, clarified by hearing, valuing, gaining from the other. 
Conflict Skills Seminar

Session VIII

= = = = = = = = = = = = = = = = = =

Handout $A$

THE CHRISTIAN LEADER IN CONFLICT SITUATIONS

OUTLINE

I. Pre-session

Handout A--"Outline"

II. Feedback on the homework assignment (15 minutes)

Feedback on Handout G ("Ministering to Antagonists") from Session VII.

III. Biblical study (15 minutes)

Handout B--"Bible Study--Gifted Leadership"

God appoints leaders for the sake of the church.

IV. A Christian style of conflict intervention ( 27 minutes)

Handout C--"Functions of Leadership"

Handout D--"Christian Leader as a Model of Loving Confrontation"

Handout E--"Reaction to Conflict"

A Christian leader approaches conflict with a set of predetermined values.

V. Attending skills (15 minutes)

Handout F--"Personal Qualities and Attending Skills for Communicating"

Communication is enhanced if body language is congruent with verbal communication.

VI. Homework assignment ( 3 minutes)

Handout G--"Thoughts to Contemplate"

An at home reading assignment to be completed at leisure.

VIII. Evaluation (15 minutes)

Handout $\mathrm{H}--$ "Conflict Attitude Test"

Handout I--"Feedback Sheet" 


\section{BIBLE STUDY--GIFTED LEADERSHIP}

Directions: Divide into four groups. Study the scripture that is assigned to your group.

1) Select someone in your group to read the text a loud.

2) Discuss and record the point or points the text adds to your understanding of leadership.

3) Finally, select a short phrase that best expresses the key thought of your text.

"Hence I remind you to rekindle the gift of God that is within you through the laying on of my hands; for God did not give us a spirit of timidity but a spirit of power and love and self-control." 2 Tim 1:6-7 (RSV).

"Now in these days when the disciples were increasing in number, the Hellenists murmured against the Hebrews because their widows were neglected in the daily distribution. And the twelve summoned the body of disciples and said, 'It is not right that we should give up preaching the word of God to serve tables. Therefore, brethren, pick out from among you seven men of good repute, full of the spirit and of wisdom, whom we may appoint to this duty. But we will devote ourselves to prayer and to the ministry of the word.' And what they said pleased the whole multitude, and they chose Stephen, a man full of faith and of the Holy spirit, and Philip.. . . These they set before the apostles, and they prayed and laid their hands upon them." Acts $6: 1-6$ (RSV).

"And his gifts were that some should be apostles, some prophets, some evangelists, some pastors and teachers, to equip the saints for the work of ministry, for building up the body of christ, until we all attain to the unity of the faith..." Eph 4:11-13 (RSV).

"But avoid stupid controversies, genealogies, dissensions, and quarrels over the law, for they are unprofitable and futile. As for a man who is factious, after admonishing him once or twice, have nothing more to do with him, knowing that such a person is perverted and sinful; he is self-condemned." Titus 3:8-11 (RSV). 


\section{FUNCTIONS OF LEADERSHIP ${ }^{1}$}

There are a number of things that leadership can do that will prepare the way for effective conflict management. The ultimate goal of the management of conflict is to move the congregation out of the chaos and confusion of enmity into reconciliation. Leaders can help people to choose to cope with difficult situations, help them feel in charge of themselves and the organization while not denying the right of others also to share in the control of that organization. Ultimately the goal is to move from enmity to amity, to move from malevolence to benevolence.

The intermediate steps toward this ultimate goal are as follows:

1) Making clear decisions. One of the most important steps to reconciliation is the ability of the organization to make a decision about its difficulties. often people wait too long before making the necessary decisions. This increases pain and drags out the difficulties. Conflict management-is the art of decision making, cutting off the fight and getting on with the business of the organization.

2) Increasing tolerance for difference. Leadership should teach members to appreciate the fact that people do differ and that is not all bad. Opposing opinions can be helpful for clarifying problems and surfacing differing levels of need. Differences are NOT a sign of failure.

3) Reducing aggression. Leaders should make it clear by modeling and by word that behavior directed at hurting, belittling, destroying, or getting rid of others is not helpful. Much more useful is behavior aimed at changing or improving others or, at least, stopping behavior that is hurting or harmful to others. Aggression differs from assertive behavior in that it is not carefully planned to be a loving act.

4) Reducing passive be $\underline{\text { havi }}$ 으. Quitting, "going limp."

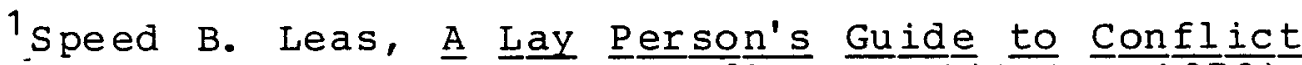
Management (Washington, D.C.: Alban Institute, 1979), pp. 7-8. 
Conflict Skills Seminar Session VIII

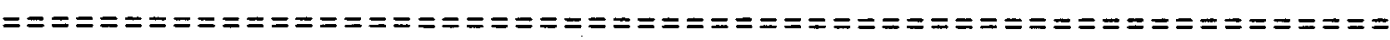
Page 2

withdrawing is not helpful because it does not allow for the joining of the groups or individuals in a collaborative effort to find a mutually acceptable solution. Even if a passive person "goes along" with the decision, his/her commitment will be weak and the relational bonds will more likely be insecure than they would be if the person or group spoke up and participated in the conflict.

5) Reducing covert, manipulative behavior. Both of these imply secret commitments not to go along with the other group or groups. The whole purpose of conflict management is to get joint decisions. Manipulative behavior produces only a forced decision with which the other may comply but to which it is unlikely there will be commitment. 


\section{CHRISTIAN LEADER AS A MODEL OF LOVING CONFRONTATION}

The style of communicating, confronting, asserting, and affirming used by a congregation's leadership tends to reappear quickly in others. If in a tense moment of conflict a leader responds firmly and caringly, those who observe can learn to do the same.

Example:

Dave's "come let us play ostrich" speech seemed to be carrying the day with the church board: "The only way to avoid a split in the church is to look the other way until this doctrinal issue dies down. If we can just ignore those agitating this situation--give them no attention at all--they'll lose their appeal. Let them have their little meetings; we'll get on with business as usual."

Several spoke in favor of Dave's idea. Then Mark said, "If we ignore a group with as much visibility as those involved in this doctrinal issue, that can only mean rejection to them. I have decided that I will neither reject these people nor allow myself to be rejected by them. I'm going to keep my friendships alive with them. I'll even be sitting in on some of their meetings. I will not let myself be walled out."

\section{Affirmation and Assertion}

This illustrates a kind of action that is both positive and powerful; it is also unfamiliar behavior to most persons. We are more familiar with either affirmation or assertion but seldom see both of these qualities together. To be assertive (act powerfully), however, does not require any loss in affirmativeness (act positively). Nor does an increase in affirmativeness necessarily decrease one's power in being assertive. Care for relationships (affirmative action) and concern for goals (assertive action) are coequal components of effective response to others.

${ }^{1}$ David $W$. Augsburger, Anger and Assertiveness in Pastoral Care (Philadelphia; Fortress Press, 1979), pp. $50-55$. 
Conflict Skills Seminar

Session VIII

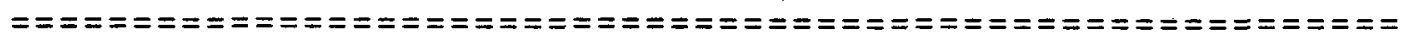
Page .2

Handout $D$

Defining anger as that which motivates us to action, notice the following elements of affirmative/assertive behavior:

Assertive anger focuses its demands clearly and acts firmly, whether in changing one's own behavior or in requesting appropriate change from another.

Affirmative anger acknowledges the equal worth of both myself and you.

Destructive, nonaffirmative anger attacks persons. It erects barriers and creates distance. It commonly takes the form of blaming and cutting criticism: "You are an insensitive lout." "I am totally fed up with you and your blaming." Notice the labeling, the blaming, the rejection and withdrawal.

Affirmative anger, on the contrary, attacks the situation between us. It cuts through the tension and confusion, levels the accumulating misunderstandings between the parties, and seeks to reduce distance and distrust: "I am angry about the misunderstandings that keep on accumulating between us." "I miss the times when we're close and everything is open between us." Notice the focus on the issues between the frustrations separating us.

\section{Assertive-Affirmative Balance}

Assertiveness means having something to stand FOR. Affirmativeness means having someone to stand WITH.

Effective assertiveness is grounded in authentic affirmativeness. The two need to be brought together in appropriate fashion. The leader who models an appropriate assertive-affirmative balance will be able to stand FOR human values while standing WITH the humans valued. The balance will show up in a variety of ways:

\section{TRUSTING/RISKING}

There is a balance, a relationship of interdependence, between ability to trust and willingness to risk. Trust and $r i s k$ go hand in hand in human relationships. As trust increases, new risks can be taken. Each additional risk taken represents both an extension of the trust experienced and an invitation to the expression of 
greater trust. Risk is grounded in trust. I trust you to be able to hear me express my frustration without feeling blamed or rejected.

\section{LOVING/LEVELING}

Love is the opening of the self to another. Leveling. is the open sharing of that self in all its dimensions. open loving and openly leveling are intimately, indeed integrally, related. The kindest and most loving thing I can offer you is the truth. When I love you, I share with you my perceptions, values, beliefs, and feelings-my self. But I am loving only if as I offer "my" truth I am equally open to hearing and receiving yours. I not only love to level; I love your leveling as well.

\section{CARING/ CONFRONTING}

A balance needs to be struck between caring for your needs and confronting the issues between us. Indeed, the two go hand in hand. Whoever cares confronts. Whoever does not confront does not care. Confronting is grounded in caring. When a firm base of caring exists, differences can be hassled, frustrations aired, and mutually satisfactory solutions sought. Caring means bidding others to grow, to realize what they truly are and are becoming.

\section{EMPATHY/INSIGHT}

The insight I would offer you must be balanced by a sensitivity to what you are actually experiencing. Empathy and insight are needed in equal measure. Understanding must precede interpretation. I need your support as much as your criticism. The empathic leader stands WITH others before offering them insight. 


\section{A TWO-DIMENSIONAL MODEL OF LOVE AND POWER}

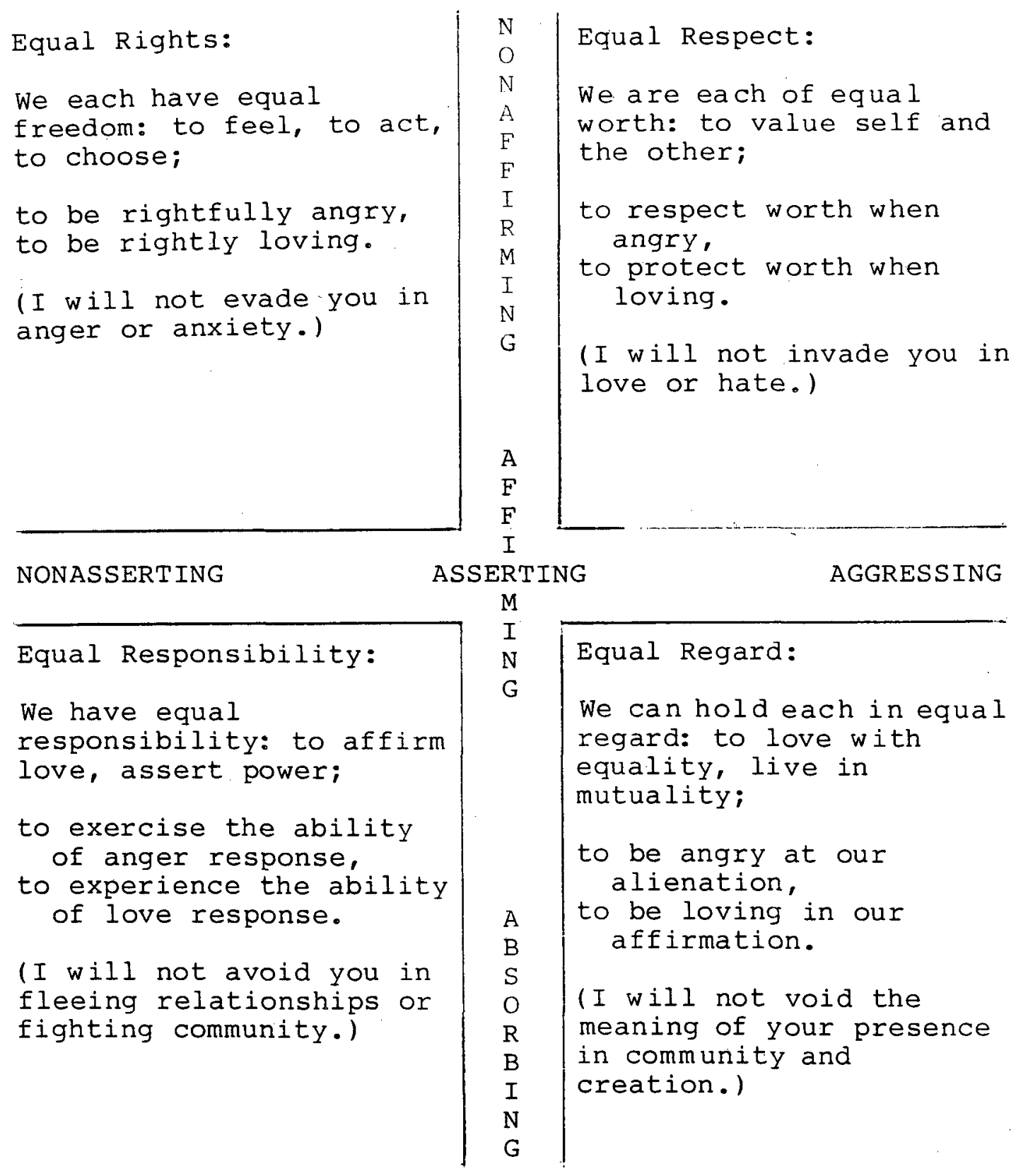


Directions: Write down what you feel would be appropriate responses to the following situations. Be prepared to share your thoughts.

1) You just happen to be in a small group that has informally gathered in the foyer following the church service. Several are angry with the nominating committee's report released that morning. It seems that a cherished but elderly man has been removed as church elder. Someone says, "I think it's awful the way they treated him. He has been a leader for years and now they've dropped him like so much garbage."

2) You are responsible for keeping the financial records straight in your home. Your spouse has had the habit of writing checks without noting the amount in the checkbook and not being able to recall the amount when asked. During the last week, he/she wrote three checks without recording the amount. You feel that now is the time for confrontation.

3) Your child has come home with a sad story of illtreatment by the teacher at school. It seems that a group of children were being rowdy in the back of the classroom about the time when your child went by them to sharpen his/her pencil. The teacher mistook your child's facial expression for mischievousness and wrongfully accused and punished him/her. If this had been the first such incident, you might have let it pass but you feel that you must confront the teacher in this situation.

4) It has gotten back to you that a friend has revealed something that you told him/her in confidence. You are embarrassed and hurt. You don't want to lose a cherished friend but you can't trust this one as things are now. You decide that it is best to confront him/her. 
Observation tells us that certain people have greater success in communicating than others. This fact has led researchers to analyze the combination of personal qualities and skills that are most likely present in good communicators.

PERSONAL QUALITIES:

The attending skills that are listed in the next section can be learned from books and developed by practice. The personal qualities suited for communication, however, are less likely learned and most likely caught. For the Christian, these qualities are God-inspired and Spiritgiven. You may be able to contrive some of the personal qualities (for instance, sincerity) by means of posture, vocal tone, etc. but there is no substitute for the genuine article that comes when the spirit works on the heart.

$\begin{array}{ll}\text { Personal Dimension: } & \text { Skills Emphasis: } \\ \text { Empathy } & \text { Listening/reacting to needs } \\ \text { Respect } & \text { Suspending frame of reference } \\ \text { Genuineness } & \text { Communicating self cautiously } \\ \text { Concreteness } & \text { Focus on feelings/events } \\ \text { Sincerity } & \text { Accurate "I" statements }\end{array}$

\section{ATTENDING SKILLS:}

A first impression of the term "attending skills" may be that attending is a passive act. on the contrary, attending is active because it is something that the communicator does.

The theory behind the attending skills is that body language projects one's interest and degree of participation during dialogue with others. What is your body language communicating?
Attending skill:
Component description:
Distance
Eye contact
Three to four feet
Gesture
Eye to eye but don't stare Open (not crossed) 
Conflict Skills Seminar

Session VIII

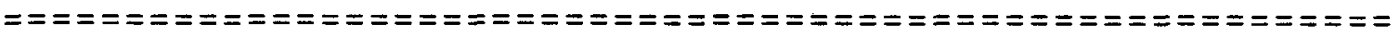
Page 2

Posture

Verbal

Touching

Noise
Lean toward person in a relaxed manner Avoid asking inappropriate questions, taking the topic in new direction, or adding to meaning

Light, quick, sincere--avoid any touch that might be interpreted as sexual in nature

Avoid communication inhibiting mannerisms 


\section{THOUGHTS TO CONTEMPLATE ${ }^{1}$}

WALKING OUT

old Self Instructions--walk out, clam up, shut off: Clam up when cornered.

Cut off a losing argument.

Get out of tense situations.

Send off the kids to their rooms.

Shut out unpleasant facts.

Lay off difficult employees.

Turn in your resignation when stressed.

Claim the way of escape.

New Self Instruction--work through to break through:

I will differ without withdrawing.

I will disagree without distancing.

I will care and confront without fleeing or facade.

I will work through until we break through.

JOKING

old Self Instructions--use sarcasm:

Soften the other with a smile then slip in the steel of irony.

Cover the chill of icy wit with false warmth.

Jab with a jest, but lightly.

It's nothing more than a joke.

Save your best sarcasm for when you have an audience.

New Self Instructions--delight in humor:

I will recognize that the line between tragedy and comedy is thin (my, your, our immaturity is both).

I will smile at our hassles which I once saw as tragic.

I will chuckle at our cycles which I once saw as catastrophic.

I am free as I can see my folly.

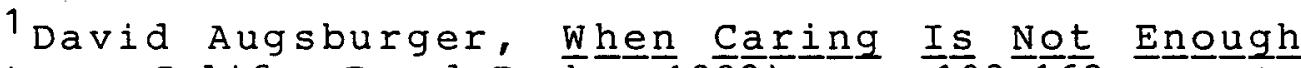
(Ventura, Calif.: Regal Books, 1983), pp. 103-163. 
Conflict Skills Seminar

Session VIII

$====$
Page 2

Handout G

QUESTIONING

Old Self Instruction--use clever questions:

Leading questions seduce.

Punishing questions ridicule.

Set-up questions manipulate.

Trapping questions bind.

Commanding questions order.

Hypothetical questions criticize (they are clever, concealed, hidden).

New Self Instructions--make clear statements:

I will make clear statements, I will welcome yours.

I will make frank requests, I will honor yours.

I will give simple invitations, I will respect yours (they're single level, and open).

\section{TRIANGLING}

old Self Instructions--pit people against people:

Quote others freely to prove your points.

Use others gladly to carry your messages.

Pit others against others to prod, or bind.

Compare others. with others to motivate or deflate.

Refer to those not present as the final court or authority.

Go through, over, around, under anyone you can, anything you can.

New Self Instructions--deal only firsthand:

I will say what I have to say

without citing others,

without using others,

without triangling others,

without involving others

as judge

as witness

as expert

as jury.

I will deal with you

one-to-one,

fact-to fact,

person-to-person.

UNDERMINING

Old Self Instructions--undermine self-esteem:

Deflate self-respect. 
= = = = = = = = = = = = = = = = = = = = = = = = = = = = = = = = = = = = = = = = = = = = = Page 3 Handout $G$

Undermine self-confidence.

Reduce independence.

Decrease autonomy.

Impugn motives.

Chip away self-esteem.

Remember vulnerable points for future use if necessary.

New Self Instructions--enrich self-esteem:

I will disconnect

self-esteem from success, self-respect from failure,

self-worth from performance, self-regard from competition, self-confidence from appearance.

My worth is not increased by winning and your worth is not insured by being right; nothing can increase or reduce it.

MARTYDOM

old Self Instructions--be a martyr (or saint):

Sacrifice, yield, surrender, comply, kowtow, submit.

Give in with longsuffering saintliness, give up with righteous superiority.

Never use obvious power when guilt and shame are available.

The sighing martyr is dynamic.

The silent martyr is dynamite.

New Self Instructions--be equal, mutual:

I will stand equal without placating.

I will stand mutual without ingratiating.

I will stand level without groveling.

I will neither use or be used.

I will never abuse nor be abused.

\section{MIND READING}

old Self Instructions--mind read, mind rape:

I have this hunch on what you're meaning.

(I'li bet I'm right, why check it out?)

I have this fantasy of what you're thinking.

(I'm sure I'm right, why ask your views?)

I have this suspicion of what you're feeling.

(I'm no dummy, it's all over your face.)

I have this conviction I can read your mind.

(I know you better than you know yourself.) 
= = = = = = = = = = = = = = = = = = = = = = = = = = = = = = = = = = = = = = = = = = = = = = Page 4

New Self Instructions--listen, wait, learn:

I will not

hunch your thoughts, second-guess your views, sense your wishes, suspect your motives, finish your sentences.

You alone can speak for you.

you alone know your heart.

\section{PROJECTING}

old Self Instructions--"you" message expose you:

You are the problem in any conflict.

You must be described, analyzed, diagnosed.

You must be confronted, lectured, persuaded.

You must be threatened, warned, punished.

You must be directed, ordered, commanded.

You must be criticized, labeled.

You must be exposed.

New Self Instructions--"I" messages reveal me:

I can only speak to my part of the problem.

I can only express my thoughts and feelings.

I can best reach you by self-disclosing.

I can gain more from you by actively listening.

I can find out your thoughts by inviting you to share them.

I can move toward you by opening myself.

I will share myself.

\section{DISARMING}

old Self Instruction--going for the kill:

If possible, intimidate.

If necessary, annihilate.

But never hesitate, or you lose.

There are no belt Iines, no safety zones; in the end you're alone!

New Self Instruction--honoring the belt line:

Never use the final weapon.

Never play the last card.

Never attack the bottom line or you both lose.

What is the profit if you win the whole world and lose your integrity? You're alone! 


\section{CONFIICT" ATHITUDE "TWEST"}

\section{READ BEFORE YOU BEGIN}

The following questions are designed to examine how you perceive conflict.

Read each question thoughtfully, then circle the number that indicates the $\mathbb{D E G R \mathbb { R }}$ to which you $\mathbb{A G \mathbb { R }}$ or $\mathbb{D I} S \mathbb{S A R \mathbb { R }}$.

It is important that you circle a number for EVERY question.

$$
\begin{aligned}
& \text { If you always or completely agree, circle } 1 . \\
& \text { If you usualiy or mostly agree, circle } 2 . \\
& \text { If you occasionally or partially agree or } \\
& \text { disagree, circle } 3 \text {. } \\
& \text { If you usualiy or mostly disagree, circle } 4 . \\
& \text { If you always or completely disagree, circle } 5 \text {. }
\end{aligned}
$$

Please be honest and candid. There are No right or wrong answers.

\section{QUESTION:}

1. Conflict occurs because of $\sin$ in $\begin{array}{llllll}1 & 2 & 3 & 4 & 5\end{array}$ the human heart.

2. I feel ill at ease when someone disagrees with me in public.

3. I avoid people who have made me angry.

4. Conflict arises because people view situations differently.

5. It is best not to bring sensitive $\begin{array}{llllll}1 & 2 & 3 & 4 & 5\end{array}$ issues to the surface because it only seems to increase conflict.

6. When in a conflict, I feel compelled to win.

7. It is best to avoid a situation that may result in conflict.

8. It is possible for conflict to have a positive effect on church life.

$\begin{array}{lllll}1 & 2 & 3 & 4 & 5 \\ 1 & 2 & 3 & 4 & 5 \\ 1 & 2 & 3 & 4 & 5 \\ 1 & 2 & 3 & 4 & 5 \\ & & & & \\ 1 & 2 & 3 & 4 & 5 \\ 1 & 2 & 3 & 4 & 5 \\ 1 & 2 & 3 & 4 & 5\end{array}$


Conflict Skills Seminar

Session VIII

Page 2

Handout $\mathrm{H}$

QUESTION:

AGREE DISAGREE

9. The church should allow people to $\begin{array}{llllr}1 & 2 & 3 & 4 & 5\end{array}$ express their differing opinions.

10. Conflict is out of place in $\quad 1 \quad 1 \quad 2 \quad 3 \quad 4 \quad 5$ the church.

11. I worry that if I get angry in $1 \begin{array}{llllll} & 2 & 3 & 4 & 5\end{array}$ a conflict I may say things that I' 11 regret.

12. I get irritated with people who $1 \quad \begin{array}{llllll}2 & 3 & 4 & 5\end{array}$ express ideas that conflict with mine.

13. Conflict closes the lines of $\quad \begin{array}{llllll}1 & 2 & 3 & 4 & 5\end{array}$ communication.

14. To love others is to avoid $\quad 1 \quad 1 \quad 2 \quad 3 \quad 4 \quad 5$ conflict with them.

15. If a person is agitated on some $\quad \begin{array}{llllll}1 & 2 & 3 & 4 & 5\end{array}$ issue in the church, he should be allowed to express his opinion.

16. Conflict is the opposite of caring for people.

17. If church members were converted, $\begin{array}{llllll}1 & 2 & 3 & 4 & 5\end{array}$ they would not be in conflict.

18. The less said when people are $\quad \begin{array}{lllllll}1 & 2 & 3 & 4 & 5\end{array}$ in disagreement the better.

19. Conflict occurs most often in $\quad \begin{array}{llllll}2 & 3 & 4 & 5\end{array}$ congregations in which there is a deep commitment to the church.

20. An open expression of differences $\begin{array}{lllllll}1 & 2 & 3 & 4 & 5\end{array}$ of opinion is good for the church.

21. If there is conflict in the church, the pastor should preach on the subject of unity.

22. I feel frustrated and upset when $1 \quad 2 \quad \begin{array}{lllll}3 & 4 & 5\end{array}$ someone gets angry with me. 
23. The church functions best when

24. I feel confident in dealing with $1 \quad 2 \quad 2 \quad 3 \quad 4 \quad 5$ people who are angry with me.

25. If there is conflict over an issue in a business meeting, it is best to limit discussion and vote before people lose control of their tempers.

26. In an argument, it may be to my $1 \quad 2 \quad 3 \quad 4 \quad 5$ advantage to point out my opponent's spiritual weaknesses.

27. Conflict is normal and unavoidable $\begin{array}{llllll}1 & 2 & 3 & 4 & 5\end{array}$ whenever people come together in organizations (including the church).

28. In a conflict, it is best to disregard people's personal feelings about the issue and stick to the facts of the issue.

29. Conflict in the church should be $\begin{array}{llllll}1 & 2 & 3 & 4 & 5\end{array}$ suppressed.

30. Majority vote is a fair and appropriate way of settling conflict.

31. One reason there is so much conflict is because people hold such unusual ideas.

32. It is not possible, for an organization to go through change without also experiencing conflict.

33. A Christian leader may find it necessary to escalate conflict. 
Conflict Skills Seminar Session VIII

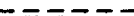

Page 4 .

Handout $H$

QUESTION

AGREE DISAGREE

34. In a conflict, I might have to

$\begin{array}{lllll}1 & 2 & 3 & 4 & 5\end{array}$ reveal some unrelated but embarrassing information about the other person if it would help truth prevail.

35. Conflict leads to positive $\begin{array}{lllll}1 & 2 & 3 & 4 & 5\end{array}$

36. Date of your birth.

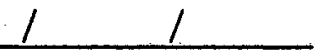

37. Number of years of education. 


\section{FEEDBACK SHEET}

Directions: Please take a few minutes to give your opinion on the various elements of the seminar listed below. Be specific. What was helpful, not helpful, exciting, stimulating, etc?

1) Handouts

2) Lectures

3) Group activities

4) Homework

5) Time (seminar length, session length)

6) How have the concepts covered in this seminar affected your conflicts? Be specific.

7) What suggestions do you have for future conflict seminars? 


\section{APPENDIX 3}

\section{EVALUATIVE EXHIBITS}

1. Descriptions of the Conflict Attitude Test

2. February 2, 1986, Control Group Letter and Conflict Attitude Test

3. March 6, 1986, Control Group Letter and Conflict Attitude Test 


\section{EXHIBIT 1 \\ DESCRIPTION OF THE \\ CONFLICT ATTITUDE TEST}

Underlying Assumption

People tend to live in accordance with their perception of reality. To do otherwise results in a psychological state called dissonance--inconsistency between one's actions and one's beliefs. Consequently, intrapersonal conflict develops that is only resolved when (1) one's perception changes to correspond to one's behavior, or (2) one's behavior changes to correspond to one's perception. Since people tend to live so that their perceptions and behavior agree, an instrument testing for one of these elements will tend to indicate the other.

\section{Purpose of the Test}

The thesis of the project is as follows:

As members of a congregation are enlightened by a biblical perspective of the nature of the church and by contemporary knowledge of human behavior, they can learn to disagree over perceived facts, methods, goals, or values without experiencing the complication of disintegrating human relationships.

The purpose of this project was to development a seminar that would teach church members methods of coping more effectively with interpersonal and/or intergroup conflict that inevitably accompanies social life. Coping was considered effective if one used certain 
communication/confrontational techniques that tend to lead conflict toward resolution without the antagonists experiencing the disintegration and dissociation in relationships that often accompanies conflict.

\section{Results Desired}

The instrument was to test the effectiveness of the seminar by attempting to ascertain if significant and measurable change occured in the participants' perception of conflict and toward the antagonists. The instrument could indicate one of three things: (1) no change in attitude; (2) a negative change in attitude; or (3) a positive change in attitude. A test result that might indicate a positive change in the participant's perception of conflict could be taken as an indication that a positive correlation exists between the seminar and that change.

The polarity of the test questions included both positive and negative statements. This assured that the respondents must agree and disagree with certain statements in order to show either a positive or negative change in attitude toward conflict.

\section{Method of development}

The instrument was applied on two occasions to two groups--a control group and the seminar group. It was designed so that the respondents could indicate their answers on somewhat of a continuum known as the Likert 
scale. This allowed for a simple design and an uncomplicated testing of the instrument.

The instrument was developed in four stages.

므르르 으르. The preliminary instrument was designed in counsel with. Dr. Roger Dudley, director of the Institute of Church Ministry at Andrews University.

Stage twwo. In order to refine the instrument, a test group was selected approximating the composition of the group likely to participate in the seminar. The test was given to this group on two occasions separated by six weeks.

The purpose of this administration of the test was to determine the consistency of results for each question. Since it was assumed that those participating in the first test group would remain constant in their perception of conflict from the time of the first testing to the second testing, those questions which showed wide variance in response were either deleted or amended.

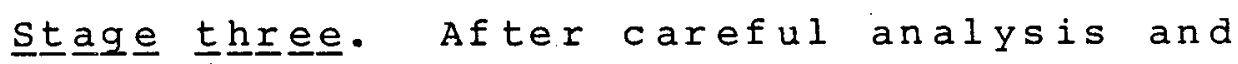
refinement based on the data from the test group and in counsel with Dr. Roger Dudley, the instrument was considered ready for application.

stage four. The instrument was applied to a control group and to the participants of the seminar. 
Test classification

Question considered:

Will a seminar on conflict change the participants' behavior in conflict situations?

Correlational question:

Will a seminar on conflict change the participants' atEitude and feelings about conflict?

Type of test:

Quasi-experimental test

Testing design:

Nonequivalent control group design with pretest and posttest

Analysis of the Testing Instrument

Table 11 analyzes the questions used in the testing instrument in several ways as noted by the key following the table. Table 12 further analyzes the positive/negative column $[(+,-)]$ in table 11 .

A casual look at table 11 demonstrates that the questions seem to be arranged in somewhat of a random fashion. An effort was made to arrange questions in such a way so a respondent's answers to certain questions would not be influenced by his answers to other questions.

Also, an attempt was made to include questions phrased positively and negatively requiring a mixed response. It was hoped that this procedure would reduce the error caused by the single response factor. 
TABLE 11

ANALYSIS OF THE QUESTIONS

USED IN THE TESTING INSTRUMENT

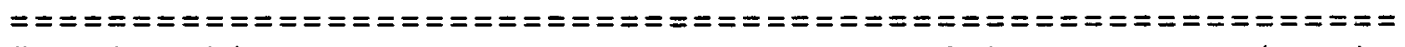

\# Question

Cat. Ses. $(+,-)$

1. Conflict occurs because of $\mathrm{sin}$ in the human heart.

A

I feel ill at ease when someone

disagrees with me in public.

3. I avoid people who have made me $E$ angry.

4. Conflict arises because people

A

view situations differently.

5. It is best not to bring sensitive $B$ to the surface because it only

seems to increase conflict.

6. When in a conflict, I feel E compelled to win.

7. It is best to avoid a situation that may result in conflict.

8. It is possible for conflict to

C

E

5

E $\quad 7$

have a positive effect on church

life.

9. The church should allow people

B

4

to express their differing opinions.

10. Conflict is out of place in the church.

11. I worry that if I get angry in a conflict I may say things that I'll regret.

12. I get irritated with people who express ideas that conflict with mine.

13. Conflict closes the lines of communication.

D 
14. To love others is to avoid

C conflict with them.

15. If a person is agitated on some

B

4 issue in the church, he should be allowed to express his opinion.

16. Conflict is the opposite of for people.

17. If church members were converted, $A$ there would be no conflict.

18. The less said when people are in $B$ disagreement the better.

B

19. Conflict occurs most often in congregations in which there is a deep commitment to the church.

20. An open expression of differences of opinion is good for the church.

21. If there is conflict in the church, the pastor should preach on the subject of unity.

22. I feel frustrated and upset when someone gets angry, with me.

23. The church functions best when conflict is not present.

24. I feel confident in dealing with people who are angry with me.

25. If there is conflict over an issue in a business meeting, it

B is best to cut off discussion as soon as possible and vote before people lose control of their temper.

26. In the heat of an argument, it may be to my advantage to point out my opponent's spiritual weaknesses. 
27. Conflict is normal and unavoidable wherever people come together in organizations (including the church.)

28. In a conflict, it is best to disregard people's personal. feelings about the issue and stick to the facts of the issue.

29. Conflict in the church should be
suppressed.

30. Majority vote is a fair and appropriate way of settling conflict.

31. One reason there is so much conflict is because people hold such unusual ideas.

32. It is not possible for an organization to go through change without also experiencing conflict.

33. A Christian leader may find it necessary to escalate conflict.

34. In a conflict, I might have to reveal some unrealted but embarrassing information about the other person if it would help truth prevail.

B

B 8

B

4

A

2

D

3

B

8

E

6

D

3 results.

Key:

$\#=$ The question number as it appears on the test.

Cat. = The subject category: A) Sources of conflict, B) Resolving conflict, C) Morality of conflict, D) Results of conflict, E) Selfappraisal in conflict.

Ses. = The session in which the question applies.

$(+,-)=$ Indicates a positive or negative phrased question.

Since the testing instrument was designed to evaluate attitudes and since there are several key 
attitudes that affect how one responds in conflict, there are a number of questions that appear to be similar that seek to evaluate a single attitude from various approaches. It seems that this is in keeping with testing procedures and aids in validating the test.

TABLE 12

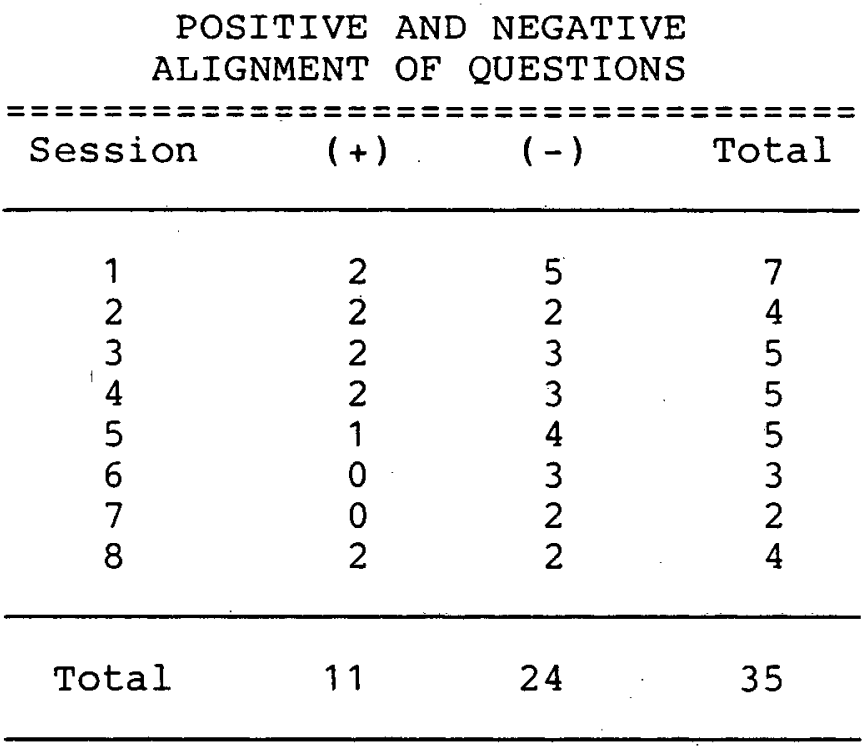

One further note may prove helpful. The test questions are conveniently divided into five categories (see table 11). The categories and the number of test questions covering each is as follows: (A) sources of conflict, six instances; (B) resolving conflict, eleven instances; (C) morality of conflict, five instances; (D) results of conflict, three instances; and (E) selfappraisal in conflict, ten instances. These categories represent the major subject areas covered in the seminar. The student is tested to see if his attitudes have 
shifted on points in these categories toward the kind of non-threatened, problem-solving, redemptive attitude that performs best in conflict. 
February 2, 1986

Dear Friend,

May I please take three minutes of your time.

You have received this letter and testing instrument from your pastor because I ask for and received his help. I am asking for your help as well. Should you decide to help, it will take an additional fifteen minutes to complete the enclosed test.

As you can see from the letterhead, I am a pastor in the ok lahoma conference. I am a lso working on a Doctor of Ministry degree through Andrews University. Part of my project/dissertation deals with an aspect of conflict management. The development of this testing instrument relates to what I am trying to accomplish in this project.

What I need you to do is complete this test today and return it in the enclosed stamped envelope. In approximately eight weeks, I will send you a second copy of the test to retake. You will also need to fill it out and return it just as you did in the case of the first test.

Should you choose to take the test, please do so without conferring with anyone else; the answers must be your own.

Thank you for you help.

Sincerely,

Jan G. Johnson, Pastor

P.S. Your test will be held in the strictest confidence. Following tabulation of the data, all tests will be destroyed. 


\section{CONHIICTI AMWTITUDE TIESTI}

READ BEFORE YOU BEGIN

The following questions are designed to examine how you perceive conflict.

Read each question thoughtfully, then circle the number that indicates the $\mathbb{D E G R \mathbb { E }}$ to which you $\mathbb{A G R \mathbb { R }}$ or $\mathbb{D I S A G R}$ :

It is important that you circle a number for EVERY question.

$$
\begin{aligned}
& \text { If you always or completely agree, circle } 1 . \\
& \text { If you usually or mostly agree, circle } 2 . \\
& \text { If you occasionally or partially agree or } \\
& \text { disagree, circle } 3 \text {. } \\
& \text { If you usualiy or mostly disagree, circle } 4 . \\
& \text { If you always or completely disagree, circle } 5 \text {. }
\end{aligned}
$$

Please be honest and candid. There are NO right or wrong answers.

QUESTION:

1. Conflict occurs because of $\sin$ in $\begin{array}{lllll}1 & 2 & 3 & 4 & 5\end{array}$ the human heart.

2. I feel ill at ease when someone $1 \quad 2 y^{3} \quad 4 \quad 5$ disagrees with me in public.

3. I avoid people who have made me $\quad \begin{array}{llllll}1 & 2 & 3 & 4 & 5\end{array}$ angry.

4. Conflict arises because people $\quad \begin{array}{lllllll}1 & 2 & 3 & 4 & 5\end{array}$ view situations differently.

5. It is best not to bring sensitive $\begin{array}{lllllll}1 & 2 & 3 & 4 & 5\end{array}$ issues to the surface because it only seems to increase conflict.

6. When in a conflict, I feel compelled to win.

7. It is best to avoid a situation that may result in conflict.

8. It is possible for conflict to have a positive effect on church life.

9. The church should allow people to $\begin{array}{llllll}1 & 2 & 3 & 4 & 5\end{array}$ express their differing opinions. 
QUESTION :

10. Conflict is out of place in

AGREE DISAGREE

the church.

11. I worry that if I get angry in a conflict I may say things that I'll regret.

12. I get irritated with people who express ideas that conflict with mine.

13. Conflict closes the lines of communication.

14. To love others is to avoid conflict with them.

15. If a person is agitated on some $\quad \begin{array}{llllll}1 & 2 & 3 & 4 & 5\end{array}$ issue in the church, he should be allowed to express his opinion.

16. Conflict is the opposite of caring for people.

$\begin{array}{lllll}1 & 2 & 3 & 4 & 5\end{array}$

12345 
QUESTION:

25. If there is conflict over an

AGREE DISAGREE

issue in a business meeting,

it is best to limit discussion

and vote before people lose

control of their tempers.

26. In an argument, it may be to my $\begin{array}{llllll}1 & 2 & 3 & 4 & 5\end{array}$ advantage to point out my opponent's spiritual weaknesses.

27. Conflict is normal and unavoidable $\begin{array}{llllll}1 & 2 & 3 & 4 & 5\end{array}$ whenever people come together in organizations (including the church).

28. In a conflict, it is best to disregard people's personal feelings about the issue and stick to the facts of the issue.

29. Conflict in the church should be $\begin{array}{llllll}1 & 2 & 3 & 4 & 5\end{array}$ suppressed.

30. Majority vote is a fair and appropriate way of settling conflict.

31. One reason there is so much conflict is because people hold $\begin{array}{lllll}1 & 2 & 3 & 4 & 5\end{array}$ such unusual ideas.

32. It is not possible for an organization to go through change without also experiencing conflict.

33. A Christian leader may find it necessary to escalate conflict.

34. In a conflict, I might have to $\quad \begin{array}{llllll}1 & 2 & 3 & 4 & 5\end{array}$ reveal some unrelated but embarrassing information about the other person if it would help truth prevail. 
QUESTION :

35. Conflict leads to positive AGREE DISAGREE results.

$\begin{array}{lllll}1 & 2 & 3 & 4 & 5\end{array}$

36. Occupation?

37. Print your name and address in the space below:

Name

Address

city State Zip 
March 6, 1986

Mr. John Smith

Rt. 1, Box 35

Oklahoma City, Ok 73123

Dear Mr. Smith,

Thank you for participating in the first testing of the "Conflict Attitude Test." Your time and effort is greatly appreciated.

I now need you to take the test a final time in order to compare the results with the first test. Enclosed you will find a fresh copy of the test. Please answer the questions as described in the instructions. Remember, do not confer with anyone else; the answers must be your own. Return the test as soon as possible in the enclosed envelope.

I assure you that your test will be held in the strictest confidence. Following tabulation of the data, all tests will be destroyed.

Thank you for your help.

Sincerely,

Jan G. Johnson, Pastor

P.S. Notice the additional information requested in question \#36. Your answer here will help make the statistical study more meaningful. 


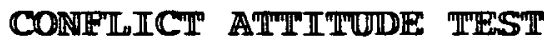

READ BEFORE YOU BEGIN

The following questions are designed to examine how you perceive conflict.

Read each question thoughtfully, then circle the number

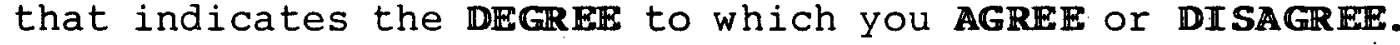

It is important that you circle a number for EVERY question.

$$
\begin{aligned}
& \text { If you always or completely agree, circle } 1 . \\
& \text { If you usually or mostly agree, circle } 2 . \\
& \text { If you occasionally or partially agree or } \\
& \text { disagree, circle } 3 \text {. } \\
& \text { If you usualiy or mostly disagree, circle } 4 . \\
& \text { If you always or completely disagree, circle } 5 \text {. }
\end{aligned}
$$

Please be honest and candid. There are No right or wrong answers.

QUESTION:

1. Conflict occurs because of $\sin$ in $\begin{array}{lllll}1 & 2 & 3 & 4 & 5\end{array}$ the human heart.

2. I feel ill at ease when someone $\quad \begin{array}{llllll}1 & 2 & 3 & 4 & 5\end{array}$ disagrees with me in public.

3. I avoid people who have made me $\quad \begin{array}{llllll}1 & 2 & 3 & 4 & 5\end{array}$ angry.

4. Conflict arises because people $\quad \begin{array}{lllllll}1 & 2 & 3 & 4 & 5\end{array}$ view situations differently.

5. It is best not to bring sensitive $\begin{array}{llllll}1 & 2 & 3 & 4 & 5\end{array}$ issues to the surface because it only seems to increase conflict.

6. When in a conflict, I feel compelled to win.

7. It is best to avoid a situation that may result in conflict.

8. It is possible for conflict to have a positive effect on church life.

9. The church should allow people to $\begin{array}{llllllll}1 & 2 & 3 & 4 & 5\end{array}$ express their differing opinions. 
QUESTION :

10. Conflict is out of place in

AGREE DISAGREE

the church.

11. I worry that if I get angry in a conflict I may say things that I'll regret.

12. I get irritated with people who express ideas that conflict with mine.

13. Conflict closes the lines of communication.

14. To love others is to avoid conflict with them.

15. If a person is agitated on some issue in the church, he should be allowed to express his opinion.

16. Conflict is the opposite of caring for people.

17. If church members were converted, they would not be in conflict.

18. The less said when people are in disagreement the better.

19. Conflict occurs most often in congregations in which there is

$\begin{array}{lllll}1 & 2 & 3 & 4 & 5\end{array}$

$\begin{array}{lllll}1 & 2 & 3 & 4 & 5\end{array}$
a deep commitment to the church.

20. An open expression of differences $\begin{array}{llllll}1 & 2 & 3 & 4 & 5\end{array}$ of opinion is good for the church.

21. If there is conflict in the church, the pastor should preach on the subject of unity.

22. I feel frustrated and upset when someone gets angry with me.

23. The church functions best when conflict is not present.

24. I feel confident in dealing with $1 \quad 2 \quad \begin{array}{llllll} & 4 & 4 & 5\end{array}$ people who are angry with me. 
QUESTION:

25. If there is conflict over an

AGREE DISAGREE

issue in a business meeting,

it is best to limit discussion

and vote before people lose

control of their tempers.

26. In an argument, it may be to my $\begin{array}{llllll}1 & 2 & 3 & 4 & 5\end{array}$ advantage to point out my opponent's spiritual weaknesses.

27. Conflict is normal and unavoidable $\begin{array}{llllll}1 & 2 & 3 & 4 & 5\end{array}$ whenever people come together in organizations (including the church).

28. In a conflict, it is best to disregard people's personal feelings about the issue and stick to the facts of the issue.

29. Conflict in the church should be $\begin{array}{llllll}1 & 2 & 3 & 4 & 5\end{array}$ suppressed.

30. Majority vote is a fair and appropriate way of settling conflict.

31. One reason there is so much conflict is because people hold such unusual ideas.

32. It is not possible for an organization to go through change without also experiencing conflict.

33. A Christian leader may find it necessary to escalate conflict.

34. In a conflict, I might have to reveal some unrelated but embarrassing information about the other person if it would help truth prevail. 
QUESTION:

35. Conflict leads to positive results.
AGREE

$\begin{array}{lllll}1 & 2 & 3 & 4 & 5\end{array}$

36. Number of years of education.

37. Print your name and address in the space below:

Name

Address

City

state

Zip 
APPENDIX 4

FEEDBACK EXHIBITS

1. Sample of the Feedback sheet

2. Responses on Feedback Sheets--Handouts

3. Responses on Feedback Sheets--Lectures

4. Responses on Feedback Sheets--Group Activities

5. Responses on Feedback Sheets--Homework

6. Responses on Feedback Sheets--Time Allocation

7. Responses on Feedback Sheets--Personal Reflection

8. Responses on Feedback Sheets--Suggestions 


\section{FEEDBACK SHEET}

Directions: Please take a few minutes to give your opinion on the various elements of the seminar listed below. Be specific. What was helpful, not helpful, exciting, stimulating, etc?

\section{1) Handouts}

2) Lectures

3) Group activities

4) Homework

5) Time (seminar length, session length)

6) How have the concepts covered in this seminar affected your conflicts? Be specific.

7) What suggestions do you have for future conflict seminars? 


\section{EXHIBIT 2}

\section{RESPONSES ON FEEDBACK SHEET}

HANDOUTS

\section{Positive Comments}

Helpful.

Very helpful. Content was well prepared.

Were well organized.

Very excellent material.

Somewhat helpful.

Fine.

With rare exception handouts were good and several excellent.

OK-- the information was very interesting and all helped.

The articles provided were stimulating and informative.

The handouts were good and provided different perspectives.

Good information and further reading material.

very helpful. I'm glad they were numbered. I could keep them organized and restudy them at home.

Well written and helpful for future reference. I have not been able to spend as much time in study as I would have liked.

course would be ineffective without such. They gave access to helpful ideas from various sources.

Very helpful--helped gel some ideas that couldn't be covered in class.

II. Negative Comments

Bit much.

I'm always confused about what is information only, homework, activities, etc.

Quite extensive. They might have had more meaning if there had been more time to discuss the information presented.

structured well although a lot of material for the amount of time.

Very informative but too much to handle in the time we spent.

It would be nicer to have a small three ring notebook to keep the papers in. We could punch holes at each class if need be.

Complete, but not in the order used in class. 
EXHIBIT 3

RESPONSES ON FEEDBACK SHEETS

LECTURE

I. Positive Comments

Very helpful.

Lively, well orchestrated, interactive.

Direct--they did not bog down on one subject. All material received attention.

Very good.

Organized and informative.

Most stimulating and helpful part of seminar.

Enlightening and enjoyable.

Superior--the teacher's ability to answer questions and give examples "made the course."

Good-helpful.

Were well done.

Felt well prepared.

Stimulating.

Excellent.

Very good--lots of examples.

Helpful.

The lectures were splendid--but couldn't remember as much of them as the handout--they helped a lot though.

The interaction between participants have been helpful. The seminar has been conducted in a very fair and helpful manner.

Helpful in bringing together materials such as handouts, etc.

Thought stimulating. Well prepared. Good explanation.

II. Negative Comments

Good--could have used a few more examples or demonstrations.

Helpful--especially the last session. I'm not sure if because I became more involved but seemed like we were not rushing through too much material too fast.

Informative but very in depth. Need more time for questions and discussion. This leads to in depth learning and clarifies ideas. 


\section{EXHIBIT 4}

\section{RESPONSES ON FEEDBACK SHEETS}

\section{GROUP ACTIVITIES}

I. Positive Comments

Helpful.

I liked the group activities--having more people's opinion on the ideas.

It is good to get ideas from others. The experiences used are real to life and are familiar happenings.

Reenforced your points. Made for clarity.

Enjoyed these. Points learned seemed to stay with me longer.

Ten sessions would allow more of these.

Excellent and fun.

OK.

Good--enjoyed.

very helpful and stimulating. When in the smaller groups you have to participate and then you seem to get more from the material.

Coordinated well; gave time to personally think, not just absorb material.

very good.

The group activity or body language was the most exciting fun, and was retained longer.

Enlightening--good teaching tool even if some are uncomfortable with them.

\section{Negative Comments}

Always helpful but sometimes a bit awkward or uncomfortable.

Good for putting theory into practice. Not enough time to cover well enough to get a real handle on the techniques. We rely mostly on old skills.

Not particularly helpful to me.

These were mediocre. Seemed like the results of the group were often vague.

Too limited because of the lack of time.

Interesting to hear reports--sometimes it was hard to get into it.

Not enough lab work. The key to change is practice. I will find it difficult to use methods for lack of familiarity in the heat of the moment.

There should be more "in house" labs to help practice what we are learning. 


\section{EXHIBIT 5}

\section{RESPONSES ON FEEDBACK SHEETS}

\section{HOMEWORK}

\section{Positive Comments}

I liked the homework. I could take my time and go over and over it until it was firmly in mind.

Gives time to contemplate alone.

Information load would be inadequate without it.

It was like schoolwork--gave time to rethink the material and relate it to our own situation.

They aligned with the subjects well an were well used tools.

Essential--well chosen articles to read.

This was good--especially important to keep it minimal.

Fine.

Good.

Adequate.

OK.

II. Negative Comments

The "fighting fair" assignment was never clear to me.

Not as helpful.

I didn't find time to do the homework each time.

Do we really complete it?

Good when I was faithful in doing it.

Not taxing. Were helpful if done in frame other than just getting it done.

We11, I didn't do too good on that one--no reflection on you.

Good but students need some incentive to do it.

Research and evaluation the most useful to me. Most of the homework material seemed to be the group activities that we didn't have time to get into.

Not difficult or time consuming, although I personally did not get mine done.

Too much.

I never seemed to really take/have the time. Maybe if time was allotted prior/during/after class. 


\section{EXHIBIT 6 \\ RESPONSES ON FEEDBACK SHEETS}

TIME ALLOCATION

I. Positive Comments

Adequate for each session. The length of time was fine. Just right. Probably optimal for being meaningful.

OK.

OK.

OK.

Good timing.

Good length.

Just about perfect.

II. Negative Comments

Shouldn't be more sessions but we could have used two hour time blocks.

Short for the amount of material we covered, a full two hours per session would not be excessive.

Wonderful! I would have enjoyed two hour sessions and think an extra half hour would have been useful.

Would recommend two hours with a ten minute break in the middle.

Need more time with a break in the middle.

Session length too short to do the group activities. Maybe 2 hours. Seminar length seems about right.

Time passes quickly at each session. Not at all boring. Length of seminar was just about right, but was hard to comprehend all the material.

Needed more time and less paper.

Perhaps longer session length and or seminar length. You need just about eight weeks to have time for all of this information to result in behavior change.

Maybe ten sessions next time.

All OK, but about fifteen minutes too early each week. 


\section{EXHIBIT 7 \\ RESPONSES ON FEEDBACK SHEETS}

\section{PERSONAL REFLECTION}

I. Comments regarding attitude changes toward conflict

I feel that having a conflict can and should be constructive. And I feel more confident that I can engage. in conflict with someone who has not had this seminar.

I look at conflict in a total different way. I feel I can deal with it better and its helped in my relationship with my wife.

They have helped me to learn to deal with the conflicts rather than avoiding them--and getting results.

I believe I can be more effective (at least if I go back and review the materiall. We've had some laughing situations at home as we reflected on how we used the concepts.

If and when conflict happens, I feel my mind would come back to the issues of this class and I could better cope with it.

I feel more comfortable in dealing with hostility and anger with better understanding of mechanics of dealing with these problems.

I do not fear a conflict quite as much and hopefully can handle it without anger or hurting the other person.

I was forced to look at my methods of conflict and see how unproductive they have been.

Helped me better see (understand) how conflicts can and should always end with improvement in the issues.

The concepts have made me aware of my need in this area.

Yes, I don't view conflict as something to always be avoided now.

I understand a little better how conflicts can be healthy. I guess I--as many others--think of conflict as negative. Now, I understand better how it can be positive.

II. Comments regarding attitude changes toward others

Given me ways to be less aggressive and more affirming in my conflicts. More understanding of the sources and nature of conflict. More understanding of different temperaments. 


\author{
EXHIBIT 7--Continued \\ RESPONSES ON HANDOUT SHEETS \\ PERSONAL REFLECTION
}

I believe for the first time in my life I now begin to understand many differences that exist between all of us. Thank you for sharing this with us.

It has helped me to understand myself better and how to relate to others and their feelings.

Helped me understand my spouse and fellow workers better--including my mom.

III. Miscellaneous comments

They have abated.

Probably reinforced some previously learned. Still grappling with basic situations as related to church actions.

I have decided to pursue the discussion of family disagreements (with my spouse, children, and parents) to see if it makes things even better. I don't feel quite as personally attacked when conflict does occur.

I've learned not to be so defensive.

I hope I've learned to fight fair. 


\author{
EXHIBIT 8 \\ RESPONSES ON FEEDBACK SHEETS
}

SUGGESTIONS

I. Suggestions regarding the seminar time/material ratio

Less material at each session so (you) could more thoroughly cover each point.

A two hour block of time.

Time for further discussion and role-playing.

More classroom practice of methods presented. (This) would reinforce and ultimately (we would) learn more.

Needed more time less paper.

Cover less material during each class. It was too much to digest at one time. Maybe have two meetings a night if time allowed. Do more of the group activities. This would be possible if less material was covered during each class--but then again you may have done this in this way to meet your school deadline.

Perhaps either lengthen the seminar or increase the session time.

Stay with present material. Individual testing and analysis is most helpful.

Go slower-old hat to you!

II. Comments regarding class domination

Try to discourage private "group sessions" during lectures.

I would suggest that you not let someone who thinks he has a good point take up too much of the class time.

I would have liked to hear from everyone more. Some students dominate and some good thinkers never speak up?

III. Comments regarding new seminars

Should be a regular thing.

Have a follow-up short course.

Make it possible to have it down to fewer sessions and try to get more church members to get the exposure.

IV. Miscellaneous comments

Many pertinent spirit of Prophecy counsels on every level of church conflict (could be used) and lessons (drawn from them). 
EXHIBIT 8--Continued

\section{RESPONSES ON FEEDBACK SHEETS}

\section{SUGGESTIONS}

If it hadn't been for this seminar, I may have been a good suicide candidate. The conflict I have (had) through the last five months have been so huge in my life (that) I don't think I could have made it. The help you have given and the guiding of the Holy spirit is really making a change in my outlook. Thank you from the bottom of my heart. Just pray for me.

I really don't have any constructive suggestion. 
B. I B L I O G R A P H Y 
SELECTED BIBLIOGRAPHY

\section{BOOKS}

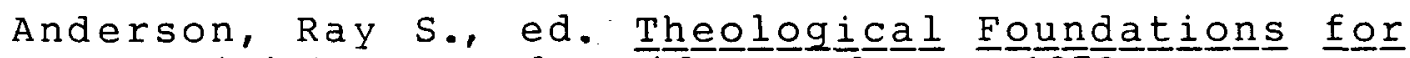
Ministry. Grand Rapids: Eerdmans, 1979.

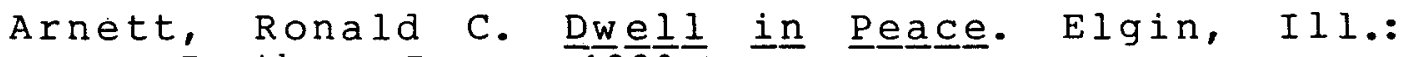
Brethren Press, 1980 .

Augsburger, David W. Anger and Assertiveness in Pastoral Care. Howard J. Clinebell series in creative pastoral care and counseling. Philadelphia: Fortress Press, 1979.

- Caring Enough to Confront. Ventura, Calif.: Regal Books, 1981.

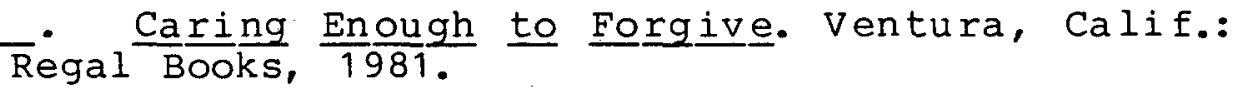
- When Caring Is Not Enough. Ventura, Calif.: Regal Books, 1983.

Bach, George R., and Goldberg, Herb. Creative Agression. New York: Avon Books, 1974.

Bach, George R., and Wyden, Peter. The Intimate Enemy. New York: Avon Books, 1968.

Bagby, Daniel G. Understanding Anger in the Church. Nashville: Broadman Press, 1979.

Barrett, C. K. "The Ministry in the New Testament." In The Doctrine 으 the Church, pp. 39-63. Edited by Dow Kirkpatrick. New York: Abingdon, 1964.

Beauchamp, George A. Curriculum Theory. 3rd ed. Wilmette, III.: The Kagg Press, 1975 .

Berkouwer, G. C. The Church. Grand Rapids: Eerdmans, 1976 .

- Sin, Grand Rapids: Eerdmans, 1971. 
Blitchington, Peter, and Cruise, Robert J. Understanding Your Temperament. Berrien Springs, Mich.: Andrews University Press, 1979.

Bonhoeffer, Dietrich. The Communion of Saints. New York: Harper and Row, 1963.

- Creation and Fall. n.p.: SCM Press, 1959; reprint ed., New York: Macmillan, n.d.

Bossart, Donald E. Creative Conflict in Religious Educa-

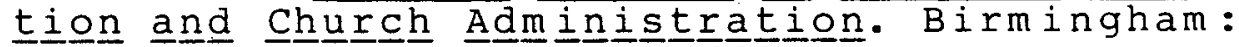
Religious Education Press, 1980.

Brammer, Lawrence. The Helping Relationship. 3rd ed. Englewood Cliff, N.J.: Prentice-Hall, 1973.

Brand, Paul, and Yancey, Philip. Fearfully and Wonder fully Made. Grand Rapids: zondervan, $19 \overline{80}$.

Brekke, Milo L.; Strommen, Merton P.; and Williams, Dorothy L. Ten Faces of Ministry. Minneapolis: Augsburg, 1979 .

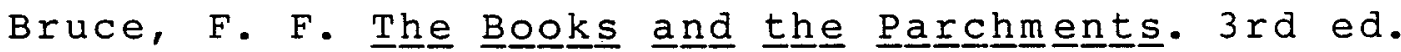
Westwood, N. J.: Fleming H. Revell, 1963.

Brunner, Emil. The Misunderstanding of the Church. Philadelphia: Westminster Press, 1953.

Buzzard, Lynn R., and Buzzard, Juanita. Resolving our Differences. Elgin, Il l.: David C. Cook, 1982 .

Buzzard, Lynn R., and Eck, Laurence. Tell It to the Church: Reconciling out of Court. Elgin, Ill.: David C. Cook, 1982.

Campbell, Stephen K. Flaws and Fallacies in Statistical Thinking. Englewood Cliffs, N.J.: Prentice-Hall, 1974 .

Carroll, Jackson W., ed. Small Churches Are Beautiful. New York: Harper and Row, 1977.

Clemmons, William, and Hester, Harvey. Growth Through Groups. Nashville: Broadman Press, 1974 .

Cohen, Herb. You Can Negotiate Anything. New York: Bantam Books, 1980 .

Coleman, James S. Cómmunnity Conflict. New York: Free Press, 1957. 
Coser, Lewis A. The Functions of Social Conflict. New York: Free Press, 1956; London: Collier-Macmillan, 1956.

Dale, Robert. Surviving Difficult Church Members. Lyle E. Schaller series in creative leadership. Nashville: Abingdon, 1984.

Dayton, Edward R., and Engstrom, Ted W. Strategy for Leadership. Old Tappan, N.J.: Fleming H. Reveil, 1979 .

Deutsch, Morton. The Resolution of Conflict. New Haven: Yale University Press, 1973: reprint ed., Binghamton, New York: Vail-Ballou Press, 1978.

Dittes, James E. When the People Say No: Conflict and the Call to Ministry. San Francisco: Harper and Row, $19 \overline{79}$

Dudley, Carl S. Making the Small Church Effective. Nashville: Abingdon, 1978.

Dunn, James D. G. Unity and Diversity in the New Testament. Philadelphia: westminster Press, 1977.

Dyer, William G. Team Building: Issues and Alternatives. Reading, Mass.: Addison-Wesley, 1977.

Eller, Vernard. War and Peace from Genesis to Revelation. 2nd ed. Scottdale, Penn.: Herald Press, 1981.

English, Fenwick W., ed. Fundamental Curriculum Decisions. A lexandria, Va.: Association for supervision and Curriculum Development, 1983.

Filley, Alan C. Interpersonal Conflict Resolution. Glenview, Ill.: Scott, Foresman and Co., 1975.

Flynn, Leslie B. Great Church Fights. Wheaton, Ill.: SP Publications, 1976.

Folger, Joseph P., and. Poole, Marshall Scott. Working Through Conflict. Glenview, Ill.: Scott, Foresman and Co., 1984 .

Garrett, Henry E. Elementary statistics. 2 nd ed. New York: David McKay Co., 1962.

Getz, Gene A. Building Up one Another. Wheaton, Ill.: SP Publications, 1979 . 
- Sharpening the Focus of the Church. Chicago: Moody Press, 1974 .

Gilchrist, Robert S., and Roberts, Bernice R. Curriculum Develolopment. Belmont, Calif.: Lear Siegler, Inc.7Fearon Publishers, 1974.

Gish, Arthur G. Living in Christian Community. Scottdale, Penn.: Herald Press, 1979.

Glaser, Robert. "Learning." In Design and Development of Curricular Materials. 2:79-116. Edited by Doris T. Gow. Pittsburg: University Center for International Studies, 1976.

Glasse, James D. Putting It Together in the Parish. Nashville: Abingdon, 1972 .

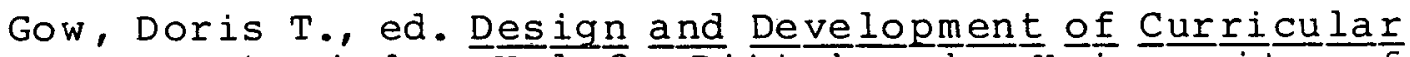
Materials. Vol 2. Pittsburgh: University of Pittsburgh, 1976.

Griffin, Em. Getting Together. Downers Grove, Ill.: InterVarsity Press, 1982 .

Guilford, J. P. Fundamental Statistics in Psychology and Education. 4th ed. New York: McGraw-Hill, 1965.

Gustafson, James M. Treasure in Earthen Vessels. New York: Harper and Bros., 1961 .

Hamburg, Morris. Basic Statistics: A Modern Approach. New York: Harcourt Brace Jovanovich, 1974 .

Haney, David. The Idea 으 the La $\underline{\text { ity. }}$. Grand Rapids: Zondervan, $\frac{19}{19} 73$.

- The Lor Press, 1978 .

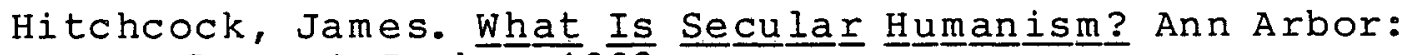
Servant Books, 1982 .

Hutcheson, Richard G., Jr. Wheel Within the wheel: Confronting the Management Crisis of the Pluralistic Church. Atlanta: John Knox Press, 1979.

Johnson, David $W_{\text {. }}$, and Johnson, Frank P. Jo으르믐 Together: Group Theory and Group Skills. Englewood Cliffs, N.J.: Prentice-Hall, 1975. 
Johnson, Douglas W. The Care and Feeding of Volunteers. Lyle E. Schaller series in creative leadership. Nashville: Abingdon, 1978.

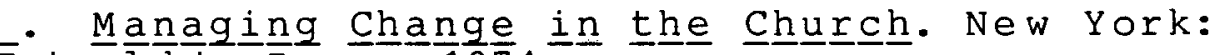
Friendship Press, 1974 .

Johnson, Robert Clyde, ed. The Church and Its Changing Ministry. Study Material prepared under the direction of the General. Assembly Special Committee on the Nature of Ministry for the United Presbyterian Church, 1961.

Kahn, Robert, and Boubling, Elise, eds. Pow ex $\underline{\text { and }}$ Conflict in Organizations. London: Tavistock, 1964. Quoted in George F. Weiland and Robert A. Ullrich, Organizations: Behavior, Design, and Change, p. 266 . Homewood, Ill.: Richard D. Irwin, 1976 .

Kelley, Arleon L. Your Church: A Dynamic Community. Philadelphia: Westminster Press, 1982 .

Kemp, Jerrold E. Instructional Design. Belmont, Calif.: Fearon Publishers, 1971.

Klimes, Rudolf E. Conflict Management in the Gospels. Berrien Springs, Mich.: Andrews University, 1977.

Klimes, Rudolf E.; Wright, Bruce R.; and Kelly, H. Ian. Conflict Management Strategies. Berrien Springs, Mich.: Andrews University, 1979.

Knapp, Mark L. Noonv르므믄 Interaction. 2nd ed. Ne w York: Hol t, Rinehart and Winston, 1978.

Kraemer, Hendrik. A Theology of the Laity. Philadelphia: Westminster Press, 1958.

Kraus, C. Norman. The Authentic Witness. Grand Rapids: Eerdmans, 1979.

Kraybill, Ronald s. Repairing the Breach: Ministering in Community Conflict. Scot tdale, Penn.: Herald Press, 1980.

LaHaye, Tim. Spirit-Controlled Temperament. Wheaton, Il 1.: Tyndale, 1982 .

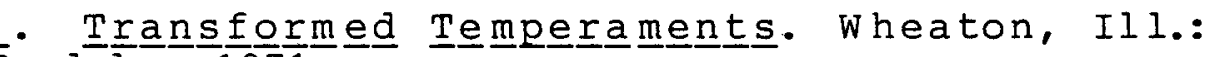
Tyndale, 1971 . 
- Understanding the Male Temperament. Old Tappan,

N. J.: Fleming H. Revell, 1977.

LaHaye, Tim, and LaHaye, Bev. Spirit-Controlled Family Living. Old Tappan, N.J.: Fleming H. Revel1, 1978 .

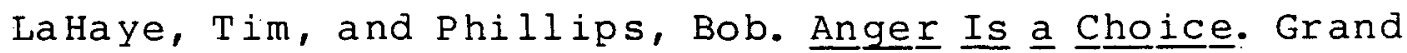
Rapids: Zondervan, 1982.

Layden, Milton. Escaping the Hostility Trap. Englewood Cliffs, N.J.: Prentice-Hall, 1977.

Leas, Speed B. Discover Your Conflict Management sty Washington, D.C.: Alban Institute, 1984.

- A Lay Person's Guide to Conflict Management. Washington, D.C.: Alban Institute, 1979.

- Leadership and Conflict. Lyle E. Schaller series in creative leadership. Nashville: Abingdon, 1982 .

Leas, Speed B., and Kittlaus, Paul. Chhurch Fights: Managing Conflict in the Local Church, Philadelphia: Westminster Press, 1973.

Lee, James Michael. The Shape of Religious Instruction. Mishawka, Ind.: Religious Education Press, 1971.

LeFevre, Perry D. Conflict in a Voluntary Association. Chicago: Exploration Press, 1975.

Leslie, Robert C. Sharing Groups in the ville: Abingdon, 1970 .

Lewis, Douglass G. Resolving Church Conflicts. San Francisco: Harper and Row, 1981.

Leypoldt, Martha M. Learning Is Change. Valley Forge, Penn.: Judson Press, 1971.

Likert, Rensis, and Likert, Jane Gibson. New Ways 으 Managing Conflict. New York: McGraw-Hili, 1976.

Lindgren, Alvin J., and Shawchuck, Norman. Management for Your Church. Nashville: Abingdon, 1977.

Littauer, Florence. Personality Plus. Old Tappan, N. J.: Fleming $H$. Revell, 1983 . 
Mack, Raymond $W_{.}$, and Snyder, Richard C. "The Analysis of Social Conflict--Toward an Overview and Synthesis." In Conflict Resolutions: Contributions 으 the Behavior Sciences, pp. 3-35. Edited by Clagett G. Smith. Notre Dame, Ind.: University of Notre Dame Press, 1971.

Martin, David W. Doing Psychological Experiments. 2nd ed. Monterey, Calif.: Brooks/Cole, 1985.

MacArthur, John, Jr. The Church the Body of Christ. Grand Rapids: Zondervan, 1973.

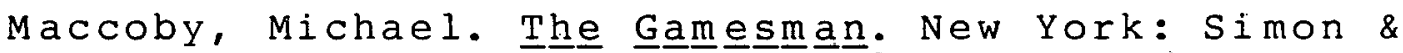
Schuster, 1976; reprint ed., New York: Bantam Books, 1978.

MCDonough, Reginald M. Working with Volunteer Leaders in the Church. Nashville: Broadman Press, 1976.

McSwain, Larry L., and Treadwell, William C., Jr. Conflict Ministry in the Church. Nashville: Broadman Press, 1981.

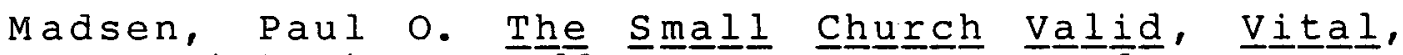
Victorious. Valley Forge, Penn.: Judson Press, $\overline{19} \frac{75}{\text {. }}$

Mager, Robert F. Preparing Instructional Objectives. 2nd ed. Belmont, Calif.: Fearon Publishers, 1975.

Martin, David W. Doing Psychology Experiments. 2nd ed. Monterey, Calif.: Brooks/Cole, 1985.

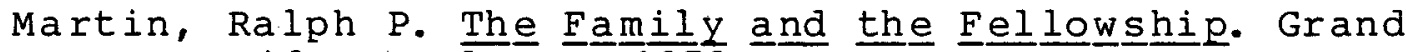
Rapids: Eerdmans, 1979.

Mavis, W. Curry. Advancing the Smaller Church. n.p.: Light and Life Press, 1957; reprint ed., Grand Rapids: Baker, 1978.

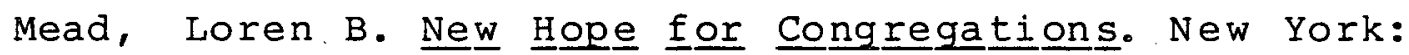
Seabury press, $\frac{1972}{19}$.

Miller, John M. The Contentious Community: Constructive Conflict in the Church. Philadelphia: Westminster Press, 1978 .

Minear, Paul S. Images of the Chhurch in the Nㅡ는 Testament. Philadelphia: Westminster Press, $19 \overline{9} 0$. 
Mitchell, Kenneth J., and Savage, John S. Skills for Calling and Caring Ministries. Pitts ford, N.Y.: L.E.A.D. Consultants, 1979 .

Moltmann, Jurgen. The Church in the Power of the Spirit. New York: Harper and Row, 1975.

- The으의의 의 브을. n.p.: SCM Press, 1967; reprint ed., New York: Harper and Row, 1975.

Negandhi, Anant R. Conflict and Power in Complex Organizations: An Inter-institutional Perspective. Kent, Oh.: Comparative Administration Research Institute of the Center for Business and Economic Research at the College of Business and Administration of Kent State University, 1972.

Nouwen, Henri J.M. The Wounded Hea ler. Garden City, N.Y.: Doubleday, 1972 .

O'Grady, Colm. The Church in the Theology of Washington, D.C.: Corpus Books, 1968.

Perry, Lloyd M., and Peterson, Gilbert A. Churches $\underline{i} \underline{n}$ Crisis. Chicago: Moody Press; 1981.

Questions on Doctrines. Washington, D.C.: Review and Herald, 1957.

Raines, Robert A. New Life in the Church. New York: Harper and Bros., 1961 ; rev. ed., New York: Harper and Row, 1980.

Ray, David R. Small Churches Are the Right size. New York: Pilgrim Press, 1982.

Remy, Richard C. Handbook of Basic Citizenship Competencies. A lexandria, va.: As sociation for Supervision and Curriculum Development, n.d.

Richards, Lawrence $O$. A New Face for the Chucㅡ․ Grand Rapids: Zondervan, 1970 .

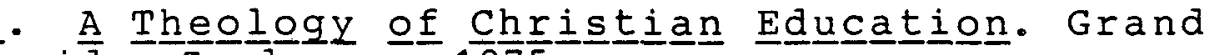
Rapids: Zondervan, 1975.

Richards, Lawrence O., and Hoeldtke, Clyde. A Theology of Church Leadership. Grand Rapids: Zondervan, 1980.

Richards, Lawrence 0. , and Martin, Gib. A Theology of Personal Ministry. Grand Rapids: Zondervan, 1981. 
Richardson, Alan. An Introduction to the Theology of the New Testament. New York: Harper and Row, 1958.

Ringer, Robert J. Winning Through Intimidation. New York: Fawcett Books, 1973.

Rohrer, Norman, and Sutherland, S. Philip. Facing Anger. Minneapolis: Augsburg, 1981.

Rosenthal, Robert, and Rosnow, Ralph L. Essentials of Behavioral Research. New York: McGraw-Hill, 1984.

Segler, Franklin M. A Theology of Church and Ministry. Nashville: Broadman Press, 1960.

Schmidt, Paul. F. Coping with Difficult People. Philadelphia: Westminster Press, 1980.

Shawchuck, Norman. How to Manage Conflict in the Church: Understanding and Managing Conflict. 2 vols. Indianapolis: spiritual Growth Resources, 1983.

Smith, Clagett G., ed. Conflict Resolution: Contributions of the Behavioral sciences. Notre Dame, Ind.: University of Notre Dame Press, 1971.

Smith, Donald P. Cllergy in the Crossfire. Philadelphia: Westminster Press, 1973.

Stagner, Ross, ed. The Dimensions of Human Conflict. Detroit: wayne state University Press, 1967. Quoted in Larry L. McSwain and William C. Treadwell, Jr. Conflict Ministry in the Church, p. 25. Nashville: Broadman Press, 1981.

Stedman, Ray C. Body Life. 2nd ed. Glendale, Calif.: Regal Books, 1977 .

Tannenbaum, Robert; Weschler, Irving R.; and Massarik, Fred. Leadership and Organization: A Behavioral Science Approach. New York: McGraw-Hill, 1961.

Tillich, Paul. Systematic Theology. 3 vols. Chicago: University of Chicago Press, 1951-63.

- What Is Religion?. New York: Harper and Row, 1969.

Torrance, Thomas F. Royal Priesthood. Edinburgh: Oliver and Boyd, 1955. 
"The Foundation of the Church." In Theological Foundations for Ministry, pp. 199-215. Edited by Ray S. Anderson. Grand Rapids: Eerdmans, 1979.

Tournier, Paul. The Strong and the Weak. n.p.: SCM Press, 1963; reprint ed., Philadelphia: Westminster Press, n.d.

Trueblood, Elton. The Incendiary Fel lowship. New York: Harper and Row, 1967.

Tyler, Ralph w. Basic Principles of Curriculum and Instruction. Chicago: University of Chicago Press, 1949; reprint ed., Chicago: University of Chicago Press, 1975.

Walrath, Douglas Alan. Leading Churches Through Change. Lyle E. Schaller series in creative leadership. Nashville: Abingdon, 1979.

Walton, Richard E. Interpersonal Peacemaking: Confronta-

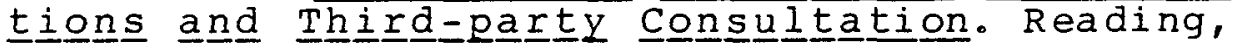
Mass.: A Ādison-Wesley Publishing Co., 1969.

Watson, Nelson A. Issues in Human Relations. Gaithersburg, Md.: International Association of Chiefs of Police, 1973.

Webber, Ross A. Management: Basic Elements 의 Managing Organizations. Rev. ed. Homewood, Ill.: Richard D. Irwin, 1979.

Welkowitz, Joan; Ewen, Robert B.; and Cohen, Jacob.

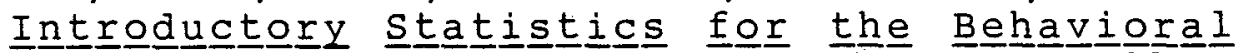
Sciences. 3rd ed. New York: Academic Press, 1982.

Wert, James E; Neidt, Charles 0.; and Ahmann, Sțanley J. Statistical Methods in Educational and Psychological Research. New York: Appleton-CenturyCrofts, 1954 .

White, Ellen G. Desire of Ages. Mountain View: Pacific Press, 1898.

- Early Writings. Washington, D.C.: Review and Herald, 1882 .

- Steps to Christ. Mountain View: Pacific Press, 1956 .

- The Great Controversy Between Christ and Satan. Mountain View: Pacific Press, 1911. 
- The Patriarchs and Prophets. Mountain View: Pacific Press, 1958.

Whitehead, Evelyn E., and Whitehead, James D. Community of Faith: Models and Strategies for Developing Christian Communities. New York: Seabury Press, 1982 .

Wieland, George F., and Ullrich, Robert A. Organizations: Behavior, Design, and Change. Homewood, Ill.: Richard D. Irwin, 1976; Arundel, Sussex: IrwinDorsey International, 1976.

Worley, Robert C. Change in the Church: A Source of Hope. Philadelphia: Westminster Press, 1971.

- Dry Bones Breathe. Chicago: Brethren Press, 1978 .

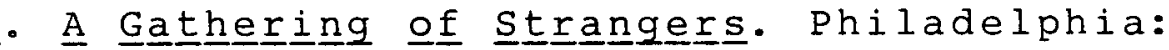
Westminster Press, 1976.

Young, Robert $\mathrm{K}_{\text {., }}$ and Veldman, Donald J. Introductory Statistics for the Behavior Sciences. New York: Holt, Rinehart and winston, 1965.

\section{JOURNALS}

Alexander, Elmore R. III. "The Reduction of Cognitive Conflict." Journal of Conflict Resolution 23 (March 1979):120-138.

Baird, Lloyd. "Managing Dissatisfaction." Personnel 58 (May-June 1981):12-21.

Bazerman, Max H., and Samuelson, William F. "I Won the Auction but Don't Want the Prize." Journal of Conflict Resolution 27 (December 1983): $618-634$.

Behling, Orlando, and Shapiro, Mitchell B. "Motivation Theory: Source of Solution or Part of Problem?" Business Horizons 17 (February 1974):59-66.

Burnham, Monty; Egmont, Westy; Hagstrom, Richard; MacDonald, Gordon; and Toms, Paul. "Leadership Forum -Conflict: Facing It in Yourself and in Your Church." Leadership 1 (Spring 1980):23-36.

Chesler, Mark A.; Crowfoot, James E.; and Bryant, Bunyan I. "Power Training: An Alternative Path to Conflict Management." California Management Review 21 (winter 1978):84-90. 
Chung, Kae H. "Toward a General Theory of Motivation and Performance." California Management Review 11 (Spring 1969): $81-88$.

Cosier, Richard A., and Ruble, Thomas L. "Research on Conflict-Handling Behavior: An Experimental

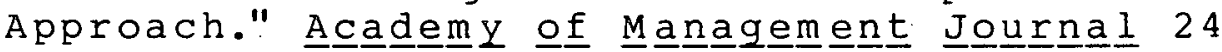
(December 1981): $816-831$.

Derr, C. Brooklyn. "Managing Organizational Conflict." California Management Review 21 (Winter 1978):7683.

Doherty, Hugh. "Management Strategies: Constructive Conflicts." Dental Management 58 (December 1984):6266.

Dudley, Roger L.; Cummings, Des, Jr.; and Clark, Greg. "Morale in Ministry--A study of the Pastor as a Person." Ministry 54 (December 1981):4-9.

Filley, A. C. "Some Normative Issues in Conflict Management." California Management Review 21 (winter $1978): 6 \overline{1-66}$.

Fisher, Delbert W. "Group Conflict May Promote Positive Solutions." Ethicon $22(1985): 16-17$.

Fisher, Ronald J. "Third Party Consultation as a Method of Intergroup Conflict Resolution." Journal 으 Conflict Resolution 27 (June 1983):301-334.

Guy, Fritz. "The Misunderstanding of the Church." Ministry 53 (August 1980):8-10.

Heisler, W. J. "Patterns of OD in Practice." Buusiness Horizens 18 (February 1975):77-84.

Hessel, Marek. "Bargaining Costs and Rational Behavior." Journal of Conflict Resolution 25 (September $\frac{\mathrm{J}}{19} \overline{81):} \overline{3} 01 \overline{-3} 3 \overline{4}$.

Hiltrop, Jean M., and Rubin, Jeffrey. Z. "Position Loss and Image Loss in Bargaining." Journal of Conflict Resolution 25 (September 1981):521-534.

Hoff, John L. "Conflict Management: An Organizational Principle." The Christian Ministry 4 (January $1973): 16-19$. 
Hunger, J. David, and Stern, Louis W. "An Assessment of the Functionality of the Superordinate Goal in Reducing Conflict." Academy of Management Journal 19 (December 1976): $5 \overline{91-605}$.

Johnston, Robert $W$. "Negotiation Strategies: Different Strokes for Different Folks." Personnel 59 (AprilMay 1982 ): 36-45.

Kilmann, Ralph H., and Thomas, Kenneth W. "Four Perspectives on Conflict Management: An Attributional Framework for Organizing Descriptive and Normative Theory." Academy 으 Management Review 3 (January $1978): 59-\overline{6} \overline{7}$.

King, Dennis. "Three Cheers for Conflict!" Personnel 58 (January-February 1981):13-22.

Kurtz, Arnold. "The Pastor and Institutionalization of Conflict Management in the Church." Andrews University Seminary Studies 20 (Autumn 1982):217227 .

- "The Pastor as a Manager of Conflict in the Church." Andrews University Seminary studies 20 (Summer 1982):111-126.

Littlejohn, Ronnie. "Ministering to Antagonists." Church Administration 23 (December 1980):17-20.

McBurney, Louis. "McBurney on Conflict Resolution." Leadership 1 (Spring 1980):117

MCDonald, Alonzo, "Conflict at the Summit: A Deadly Game." Harvard Business Review 50 (March-April $1972): 59-68$.

Mains, David, and Yancey, Philip. "My Greatest Ministry Mistakes." Leadership 1 (Spring 1980):15-22.

Newbold, Robert T., Jr. "Conflict in the Black Church." Leadership 1 (Spring 1980):99-101.

O'Day, Rory. "Intimidation Rituals: Reactions to Reform." The Journal of Applied Behavioral Science 10 (December 1974): $373-386$.

Patterson, Ben. "A Small Pump at the Edge of the Swamp?" Leadership 1 (Spring 1980):41-46.

Phillips, Eleanor, and Cheston, Ric. "Conflict Resolution: What Works?" California Management Review 21 (Summer 1979):76-83. 
Powell, Reed M., and Schlacter, John L. "Participative Management a Panacea?" Academy of Management Journal 14 (June 1971):165-173.

Price, Roy C. "Building Trust Between Pastor and Congregation." Leadership 1 (Spring 1980):47-53.

Richard, Robert C., and Olsen, Del. "Go to Your Corners and Come out Fighting! The Psychologist as

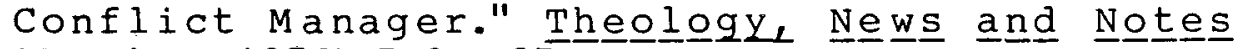
(October 1976):7-8, 27.

Robbins, Stephen P. "'Conflict Management' and 'Conflict Resolution' Are Not Synonymous Terms." California Management Review 21 (Winter 1978):67-75.

Rook, William C. "Understanding Conflict in the Church." Church Administration 23 (December 1980):15-16.

Rottenburg, Isaac. "The Christian Versus Christian." Leadership 1 (Spring 1980):59-64.

Rubin, Jeffrey Z.; Brockner, Joel; and Nathanson, Susan Small-Weil Sinaia. "Factors Affecting Entry into Psychological Traps." Journal of Conflict Resolution 24 (September 1980):405-426.

Savage, John S. "Getting In and Out of Conflict." Your Church 30 (March/April 1984):42-44, 51.

Schein, Virginia E. "Individual Power and Political Behaviors in Organizations: An Inadequately Explored Reality." Academy of Management Review 2 (January 1977): $64-72$.

Stimac, Michele. "Strategies for Resolving Conflict: Their Functional and Dysfunctional Sides." Personnel 59 (November-December 1982):54-64.

Tannenbaum, Robert, and Schmidt, warren H. "How to Choose a Leadership Pattern." Harvard Business Review 36 (March-Apri1 1958): 95-101.

Thomas, Kenneth W. "Introduction." California Management Review 21 (Winter 1978):56-60.

- "Toward Multi-Dimensional Values in Teaching: The Example of Conflict Behaviors." Acade픈 으 Management Review 2 (July 1977):484-90. 
Powell, Reed M., and Schiacter, John L. "Participative Management a Panacea?" Academy of Management Journal 14 (June 1971):165-173.

Price, Roy C. "Building Trust Between Pastor and Congregation." Leadership 1 (Spring 1980):47-53.

Richard, Robert C., and Olsen, Del. "Go to Your Corners and Come out Fighting! The Psychologist as Conflict Manager." Thheologgy, Neᅳws 므므 №t트s (October 1976):7-8, 27 .

Robbins, Stephen... P. "'Conflict Management' and 'Conflict Resolution' Are Not Synonymous Terms." California Management Review 21 (Winter 1978):67-75.

Rook, William C. "Understanding Conflict in the Church." Church Administration 23 (December 1980):15-16.

Rottenburg, Isaac. "The Christian Versus Christian." Leadership 1 (Spring 1980):59-64.

Rubin, Jeffrey Z.; Brockner, Joel; and Nathanson, Susan Small-Weil Sinaia. "Factors Affecting Entry into Psychological Traps." Journal of Conflict Resolution 24 (September 1980):405-4 $\overline{26}$.

Savage, John S. "Getting In and out of Conflict." Your Church 30 (March/April 1984):42-44, 51.

Schein, Virginia E. "Individual Power and Political Behaviors in Organizations: An Inadequately Explored Reality." Academy of Management Review 2 (January 1977): 64-72.

Stimac, Michele. "Strategies for Resolving Conflict: Their Functional and Dysfunctional Sides." Personnel 59 (November-December 1982):54-64.

Tannenbaum, Robert, and Schmidt, warren H. "How to Choose a Leadership Pattern." Harvard Business Review 36 (March-April 1958): 95-101.

Thomas, Kenneth W. "Introduction." California Management Review 21 (Winter 1978):56-60.

- "Toward Multi-Dimensional Values in Teaching: The Example of Conflict Behaviors." Academy of Management Review 2 (July 1977):484-90. 
Thomas, Kenneth W.; Jamieson, David W.; and Moore, R. Kenneth. "Conflict and Collaboration: Some Concluding Observations." Cal if ornia Management Review 21 (winter 1978):91-95.

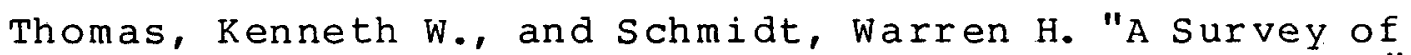
Managerial Interests with Respect to Conflict." Academy of Management Journal 19 (June 1976):315318 .

Thompson, William R., and Rapkin, David P. "Collaboration, Consensus, and Detente." Journal of Conflict Resolution 25 (December 1981): $\frac{\text { 615-637. }}{6}$

Weiss-Wik, Stephen. "Enhancing Negotiators' Successfulness." Journal of Conflict Resolution 27 (December $1983): \overline{706-739}$.

Wilken, Paul H. "Size of Organizations and Member Participation in Church Congregations." Administrative Science Quarterly 16 (June 1971):173-9.

\section{THESES}

Giller, Eoin Barnard. "Building Up the Body of Christ -A Study in Church Revitalization Leading to Church Growth." D.Min. project report, Andrews University Theological seminary, 1977.

Kurtz, Arnold A. "A Design for Continuing Education in Church Leadership for Clergymen." D.Min. project report for McCormick Theological Seminary, 1965.

\section{PAPERS}

Johnson, Robert clyde, ed. The chhurchh and $\underline{\text { Its }}$ Changing Ministry. Study material prepared under the direction of the General Assembly special Committee on the Nature of Ministry for the United Presbyterian Church, 1961.

\section{DICTIONARIES, ENCYCLOPAEDIAS, AND YEARBOOKS}

"Humanism." Encyclopaedia Britannica. 15 th ed. Vol. 5 $(1983): \overline{199}$.

"Humanism." Webster's New Collegiate Dictionary. 8th ed. $(1981): 552$. 
Kalat, James W. "Perception." Encyclopedia of Psychology. Vol. $3(1984): 497-500$.

Kishner, Robert P. "Giant Voids in the Universe." 1985 Yearbook of Science and the Future (1984):48-63.

\section{TAPES}

Buzzard, Lynn R., and Eck, Laurence. A cassette tape supplied with Resolving Our Differences. Elgin, Il l.: David C. Cook, 1982 .

Shawchuck, Norman. A cassette tape supplied with 브으 toㅡ Manage Conflict in the Church: Understanding Church conflict. Indianapolis: Spiritual Growth Resources, 1983. 
$V$ I $T A$ 
VITA

\section{Personal}

I was born and reared in the Northwest; the last child in a family of five children born to Joseph and Leath Johnson. I married Meldra Rodier in 1968 and together we have two children--Cheryl born in 1972 and Wendy born in 1977 .

\section{Educational}

In 1970 .I received a B.A. from Walla Walla college (College Place, Washington) in Theology with minors in Sociology and speech. I received a Master of Divinity from the Seventh-day Adventist Theological Seminary, Andrews University, in 1973. This project completes the requirements for a Doctor of Ministry degree.

\section{Professional}

I have served as a Seventh-day Adventist pastor in three conferences: Oregon conference from 1973 to 1979 ; Mountain View conference from 1980 to 1985 ; and Oklahoma conference since 1985. My goals for the future include publishing articles and books for teens and adults with the theme of developing and preserving interpersonal relationships. 